\title{
Assessing treatment outcomes in multiple sclerosis trials and the clinical setting
}

Working title: Outcomes in multiple sclerosis

Carmen Tur ${ }^{1}$, Marcello Moccia ${ }^{1,2}$, Frederik Barkhof ${ }^{1,3,4,5}$, Jeremy Chataway ${ }^{1,5}$, Jaume Sastre-Garriga ${ }^{6}$, Alan J Thompson ${ }^{5,7}$, Olga Ciccarelli ${ }^{1,5}$

1 Queen Square Multiple Sclerosis Centre, University College of London, UCL Institute of Neurology, London WC1B5EH, UK

2 Multiple Sclerosis Clinical Care and Research Centre, Department of Neuroscience, Federico II University, Naples, Italy.

3 Institute of Healthcare Engineering, UCL, London

4 VU University Medical Centre - Radiology \& Nuclear Medicine, 1007 MB Amsterdam, the Netherlands

5 National Institute for Health Research University College London Hospitals Biomedical Research Centre

6 Multiple Sclerosis Centre of Catalonia (Cemcat), Neurology-Neuroimmunology Department, Vall d’Hebron University Hospital, Barcelona, Spain

7 UCL Faculty of Brain Sciences, Institute of Neurology, Department of Brain Repair and Rehabilitation, Queen Square, London, UK 


\section{Acknowledgements}

CT acknowledges the ECTRIMS post-doctoral research fellowship for the financial support. JC, FB, AJT and OC acknowledge funding from the UK National Institute for Health Research (NIHR) University College London Hospitals/University College London Biomedical Research Centre.

\section{Conflicts of interest}

CT has received an ECTRIMS post-doctoral research fellowship in 2015. She has also received honoraria and support for travelling from Bayer-Schering, Teva, MerckSerono and Serono Foundation, Biogen, Sanofi-Aventis, Novartis, and Ismar Healthcare.

MM has received salary from the Federico II University of Naples, Italy. He has also received honoraria and support for travelling from Merck-Serono, Genzyme, Coloplast and Almirall.

FB has received research support from the IMI (H2020) program AMYPAD, the Dutch MS Society and the NIHR UCLH Biomedical Research Centre. He has received consulting fees for work done in steering committees, data-safety monitoring boards and advisory boards from Bayer Schering Pharma, Sanofi-Aventis, Biogen-IDEC, Teva, Merck-Serono, Novartis, Roche, Synthon BV, Jansen Research, and Genzyme.

JC acknowledges the UK National Institute for Health Research (NIHR) University College London Hospitals Biomedical Research Centres Funding scheme and 
University College London (UCL). He has received support from the Efficacy and Mechanism Evaluation and Health Technology Assessment Programmes (NIHR); and the UK and National Multiple Sclerosis Societies. In the last three years he has been a $\underline{\text { local principal investigator for trials in multiple sclerosis funded by: Receptos, Novartis }}$ and Biogen Idec, and has received an investigator grant from Novartis outside this work. He has taken part in advisory Boards/consultancy for Roche, Merck, Biogen, MedDay and Apitope.

IC has received support from the Efficacy and Mechanism Evaluation Programme (NIHR) and UK Multiple Sclerosis Society, is the local principal investigator for trials in multiple sclerosis funded by Novartis, Biogen, and GSK, and has received an investigator grant from Novartis outside this work. He has taken part in Advisory Boards for Roche and Merck.

JSG has received honoraria as speaker and for participation in Advisory Boards in the last 36 months from Novartis, Biogen, Merck, Almirall, TEVA, Celgene and Genzyme.

AJT receives grant support from the Multiple Sclerosis Society of Great Britain and Northern Ireland, and has received honoraria/support for travel for consultancy from Eisai, Biogen (Optum Insight), and Excemed. He received support for travel from the International Progressive MS Alliance, as chair of their Scientific Steering Committee and the National MS Society (USA) as member of their Research Programs Advisory Committee, and receives an honorarium from SAGE Publishers as Editor-in-Chief of Multiple Sclerosis Journal. 
OC receives research grant support from the Multiple Sclerosis Society of Great Britain and Northern Ireland, the NIHR UCLH Biomedical Research Centre, and she is a consultant for Teva, Roche, Novartis, Biogen, Genzyme and GE. She is an Associate Editor for Neurology, for which she receives an honorarium.

Word count/tables/figures/boxes/supplementary tables/references: Abstract: 222 words; Main text: 8,443 words; \# tables: 43; \# figures: 2; \# supplementary tables: 8; \# boxes: 217; \# references: 1966. 


\section{Abstract}

Increasing numbers of drugs are being developed for the treatment of multiple sclerosis. Measuring outcomes is key to assessing the efficacy of drugs in clinical trials and monitoring response to disease-modifying drugs in individual patients treated upon registration. In both clinical trials and the clinical setting, most outcomes reflect relevant aspects of the disease, from clinical or neuroimaging perspectives, such as the presence of clinical relapses and accrual of disability, or the presence of visible inflammation and brain tissue loss, respectively. However, most of the measures employed in clinical trials to assess treatment effects on these relevant outcomes (i.e. outcome measures) are not used in routine practice. In the trial setting, the choice of outcome measures is crucial because they determine whether a drug is considered effective and can move to the next step of development; in the clinic, such outcome measures may be used for individual decision-making, such as choosing a first-line disease-modifying drug or escalating to a second-line treatment. This review discusses the clinical, neuroimaging, and combined outcome measures, including patientreported ones, that are used in both trials and the clinical setting, to help clinicians and researchers to navigate through the multiple options when choosing an outcome measure. The barriers and limitations that need to be overcome to translate outcome measures from trials to a clinical setting are also discussed.

\section{Introduction}


Multiple sclerosis (MS) is a major cause of irreversible disability in young adults. Neurological disability in MS may occur as a consequence of acute relapses with incomplete recovery, or as a result of a clinical progression that occurs independently of the presence of relapses ${ }^{1}$. The pathological processes that lead to the development of acute disability are different from those that contribute to clinical progression. Acute inflammatory demyelination is responsible for the development of relapses, whilst neurodegeneration is the main determinant of progressive disability ${ }^{2}$. There are no-few licensed treatments to slow progressiveion in MS, whilst numerous diseasemodifying treatments (DMT), which reduce the frequency of relapses in relapsingremitting (RR) MS, are available. Current efforts are shifting towards progressive $\mathrm{MS}^{3}$, and the number of trials has increased steadily over the last five years.

Measuring appropriate outcomes is central to assessing the efficacy of novel drugs, determining whether a drug can be moved to the next step of a drug development programme, and its regulatory approval. The efficacy of an experimental therapy cannot be demonstrated if the selected measure is unable to capture it, and no trial designs can compensate for inappropriate and poor measures. Outcome measures in RRMS trials focus on clinical (relapse) and radiological (lesion count) disease markers of inflammation, whilst in progressive MS the emphasis is on measures of clinical progression and (brain) atrophy as markers of neurodegeneration. Ideally DMTs would prevent both inflammation and neurodegeneration ${ }^{4}$.

In the clinical setting, similar measures are used to monitor the response to DMTs in the individual patient, and, consequently, for decision-making, such as choosing a 
specific initial DMT or escalating to second-line treatment. Although Amost of the outcome measures used in clinical trials are not-used in routine practice, the level of standardization and the quality control are lower in the clinic than in trials, because of technical, financial and logistic barriers. However, important efforts have been made to standardise outcome measures in the clinic, especially in relation to monitoring treatment efficacy, in order to allow comparisons across centres ${ }^{5,6}$.

The answer to the question what makes an outcome measure appropriate is a complex one. The psychometric properties of the measure must be appropriate for the study, and the chosen measure should be reliable and valid. Reliability indicates that the data collected are accurate and reproducible, while validity refers to the ability of the tool to measure what it is supposed to measure. In addition, the outcome measure must be responsive, i.e., detect changes in the specific functions and areas that are expected to occur as a consequence of the intervention/therapy ${ }^{7}$. The degree of the predicted changes in the outcome measure and the period over which they are expected to happen are also factors that need to be considered ${ }^{8}$. Well-known, traditional endpoints used in MS trials have the advantage that are immediately understood by clinicians, whereas novel outcomes may provide insights into more subtle, but relevant, treatment effects that would have been overlooked when using traditional endpoints. In the clinical setting, the choice of a response measure needs to consider whether the administration of the tool is easy, the data collected are clinically useful, and the interpretation of the test results is straightforward. 
This review discusses the clinical and imaging outcomes used in clinical trials, stressing their advantages and limitations, which need to be considered when interpreting the results of clinical trials or designing new studies, with a particular focus on combined outcomes, as recently employed in progressive MS trials. The response measures used in routine clinical practice are also reviewed, and attention is given to their value and practicality. Clinically meaningful outcomes from the perspectives of patients and healthcare professionals are also discussed, with a view on their complementary role to more classical (objective) outcomes to detect treatment effects.

\section{Outcomes in clinical trials}

In this section, we first describe the clinical, neuroimaging and the other outcome measures that have been used in clinical trials, especially in phase III trials, and then the combined clinical and MRI measures.

\section{Clinical outcomes}

We have divided the clinical outcomes used in clinical trials into: clinical relapses, measures of disability progression, and patient reported outcome measures (PROMs). Relapse-based outcomes are prevailing in trials with RRMS patients, whereas progression-related outcomes are prominent in progressive MS trials. PROMs can be observed in all types of trials., but may be particularly relevant in trials with progressive MS patients, who are more likely to present with symptoms such as fatigue, pain or depression, than RRMS $^{9}{ }^{10}$ Regulatory agencies have therefore shown 
a growing interest in the use of PROMs for trials in MS over recent years ${ }^{9,10}$ to measure common and disabling symptoms such as pain, fatigue and depression.

\section{Clinical relapses}

The majority of phase III trials have been carried out in patients with RRMS, and, to a lesser extent, with the clinically isolated syndrome (CIS) (Figure 1). Since these trials aim to reduce (or suppress) the inflammatory activity responsible of acute relapses, theif main outcome measure is relapse counting (Tables 1 and Supplementary Tables 1 and 2).

These relapse-centred outcome measures can be classified into four groups (Supplementary Tables 1 and 2): (i) quantification of the number of relapses in a discrete fashion (which are the most widely used) (ii) those that quantify the number of relapses as a binary phenomenon, such as the proportion of patients without relapses (relapse-free population) -or its opposite - the proportion of patients with at least one relapse (non-relapse-free population)-, (iii) metrics that quantify the time to the first relapse while on treatment (which are common in trials in CIS patients), and (iv) composite outcome measures.

An additional group that could be considered is based on the severity of the relapses, such as those associated with hospital admissions and intravenous steroids.

A relapse is generally defined as new or recurrent neurological abnormalities that are separated by at least 30 days from the onset of the preceding event. It lasts at least 
$24 \mathrm{~h}$, and occurs without fever or infection ${ }^{11}$. The definition of a relapse has changed over time and has become more stringent in recent trials compared with early trials $^{12,13}$. For example, in the phase III ALLEGRO trial, which compared laquinimod with placebo in RRMS, neurological symptoms had to last at least $48 \mathrm{~h}$ to be considered relapses ${ }^{13}$. The vast majority of Some-trials demand an objective assessment by the examining neurologist ${ }^{16}$, and request a specific increase in the Expanded Disability Status Scale (EDSS) score and associated Functional System sub-scores ${ }^{14-16}$.

The most widely used outcome measure is the annualised relapse rate (ARR: number of relapses during the treatment period per patient-year), which belongs to the first abovementioned-group (i) above and has been used so far in more than 40 phase III trials, most of which are in RRMS (Table 1 and Supplementary Table 1). In more than half of these trials, and in all trials with RRMS, the ARR has been used as the primary trial endpoint (Table 1). The ARR is easy to understand and compute, and it is thought to reflect well the extent of inflammatory activity of the disease. However, it may lack specificity in respect to MS course severity, since the background level of disability and the severity of the attack are not captured. This limitation has prompted the development of the annualised rate of severe relapses, which are those relapses that require intravenous steroid treatment and/or hospitalisation ${ }^{13}$, or those that entail a high-level of disability ${ }^{17}$, which has been used since 1993 as a secondary endpoint (Table 1). However, the lack of standard guidelines to treat MS relapses implies there is an enormous inter-site variability in terms of management of relapses and it might not be appropriate to consider these measures as potentially eligible clinical outcomes in trials. 
The second group of relapse-centred outcome measures includes the relapse-derived binary outcome measures, which have been used since the very beginning of the trials in MS, but have become more popular over recent years with the testing of highly effective drugs that may lead to a relapse-free status. The percentage of relapse-free patients and the percentage of patients with at least one relapse may depend on the length of the study, as the risk of getting a relapse may increase with time; therefore, the design of the study needs to be considered when comparing these outcome measures among trials. For example, the GATE study, a 9-month placebo-controlled phase III trial, where generic glatiramer acetate (GA) was compared to brand GA and placebo in RRMS patients, the percentage of relapse-free patients in the placebo group was $79.3 \%$. Instead, in RRMS trials with longer durations, usually 24 months, such as the FREEDOMS ${ }^{14}$ or the ALLEGRO ${ }^{13}$ studies, that percentage is around $50-60 \%$. This has immediate consequences from a statistical point of view: to be able to detect a given difference in relapse-free patients between placebo and active arms, we will need much greater sample sizes if the percentages in both groups are around $50 \%$ than if they are closer to $0 \%$ or $100 \%$.

The most relevant measure within the third group is time-to-relapse, often used in CIS studies, where the occurrence of the first relapse since study entry indicates conversion to clinically definite MS (CDMS $)^{18-20}$; therefore, time to CDMS is often the primary trial endpoint (Table 1 and Supplementary Table 1). Since the development of a new lesion on MRI in patients with CIS can also confirm a diagnosis of MS (assuming that the dissemination in space criteria are also fulfilled), according to the 
$2001 \mathrm{McDonald}$ criteria ${ }^{20}$, time to McDonald MS has also been used as trial endpoint in CIS trials, although this measure requires a trial design with repeated MRI scans and is heavily dependent on frequency of MRI assessments. At present, a few phase III trials have used time to McDonald MS as trial endpoint: the BENEFIT study ${ }^{21}$, which compared interferon beta-1b $250 \mu \mathrm{g}$ SC every other day versus placebo, the REFLEX study $^{22}$, comparing three-weekly and weekly INTERFERON beta-1a versus placebo, and the TOPIC study ${ }^{23}$, comparing oral teriflunomide $7 \mathrm{mg}$ and $14 \mathrm{mg}$ versus placebo (Table 1). In the both BENEFIT and REFLEX studies, where time to McDonald MS was the primary outcome, this reached statistical significance well before time to first relapse and allowed for a dose differentiation in REFLEX that was not apparent using clinical outcomes ${ }^{22}$.

The most important outcome within the fourth group is "time to treatment failure", which is a primary composite endpoint, recently introduced in the TENERE study, which compared oral teriflunomide $7 \mathrm{mg}$ and $14 \mathrm{mg}$ versus interferon beta-1a in $\mathrm{RRMS}^{15}$. The time to treatment failure is defined as the occurrence of the first confirmed relapse while on treatment, or permanent treatment discontinuation for any cause ${ }^{15}$ (Table 1); this outcome is thought to account for all the factors that determine the effectiveness of a therapy, such as efficacy, safety and tolerability, and, therefore, may be applicable to the real-life clinical setting.

\section{Measures of disability progression}

Measures of disability progression are generally used as primary outcome measures in phase III trials in progressive MS (Table 1 and Supplementary Table 3). Most pRhase 
III trials in progressive MS using these outcome measures have reported negative results ${ }^{24,25}$, with the exception of the ORATORIO study, which compared IV ocrelizumab versus placebo in primary progressive (PP) $\mathrm{MS}^{26}$ and the EXPAND trial, which compared oral siponimod to placebo in secondary progressive (SP) MS ${ }^{27}$. Many trials in RRMS (and CIS) patients have also included disability progression as a trial endpoint (Table 1 and Supplementary Tables 1 and 2), either secondary or primary, suggesting that targeting clinical progression is also a may be-a-priority even-in the relapsing forms of MS.

Similarly to the relapse-centred outcomes, dDisability progression-related outcomes can be classified into four five groups: (i) those that quantify the amount of progression in a continuous fashion, such as changes in the Expanded Disability Status Scale (EDSS) ${ }^{28}$ scores, or the EDSS score at follow-up, (ii) metrics that quantify the amount of progression as a binary phenomenon, such as the proportion of patients with (or without) (confirmed) disability progression, (iii) quantification of the (confirmed) improvement in disability progression also binary, (ivii) metrics-those that quantify the time to confirmed disability progression (CDP), and (iv) composite outcome measures (see Table 1).

The most frequently used outcome measure in the first group is the absolute change in the EDSS score from baseline to follow-up (Table 1 and Supplementary Table 3). Of note, in some trials, such as the PRISMS ${ }^{17}$ and CARE-MS $\mathrm{I}^{29}$ and $\mathrm{II}^{30}$ trials, changes in the EDSS raw scores are reported, but in other trials, such as the Copolymer-1 trial in $\mathrm{RRMS}^{31}$, the EDSS-step methodology, instead of raw EDSS changes, is used. It consists 
of assigning new values to observed EDSS changes depending on the position of the initial EDSS score in the whole scale. This approach was meant to overcome the nonlinear behaviour of the EDSS. The main limitations of the EDSS-based measures are that a worsening in EDSS does not reflect which functional system changes and that a relapse-associated transient deficit may lead to a (transient) change in the EDSS ${ }^{32}$. Additionally, the EDSS may not be sensitive to deterioration of the upper limb motor function, cognitive function or short-distance walking, which may occur in patients with progressive MS and high EDSS scores ${ }^{33}$. Besides, the absolute change in EDSS, especially when relying on a small number of visits, may be affected by noise due to the low inter-rater and intra-rater reproducibility of the scale, namely in the lower end of the scale ${ }^{34}$. The EDSS score does not reflect the whole patient's functional impairment, since it has a low ability to discriminate people with different levels of disability according to the Barthel Index ${ }^{35}$, a measure of functional independence in 10 daily activities ${ }^{36}$. Therefore changes in scores other than EDSS, such as MS Functional Composite (MSFC) ${ }^{37}$, and its subtests ${ }^{38,39}$, Regional Functional System Score (RFSS), ambulation index, arm index, and cognitive tests ${ }^{40,41}$, from baseline to follow-up, have been included into some trials to complement the EDSS (Table 1 and Supplementary Table 3). Cognitive tests that have been used in phase III trials include the: Paced Auditory Serial Addition Test (PASAT), which is one the subtests of the $\mathrm{MSFC}^{37}$; Rao's Brief Repeatable Battery (Rao's BRB) ${ }^{42}$. With the PASAT, the changes in the $z$-score over the trial period time was used $^{43,44}$. For Rao's BRB, different trials have used different outcome measures: whereas in the phase III North American trial of SC interferon beta-1b in SPMS the outcome measure was the change in a composite $\underline{\text { neuropsychological score }}^{41}$ in the ARIANNA study (atorvastatin add-on vs. placebo 
add-on in RRMS patients on SC interferon beta-1b treatment), the outcome measure

was the change in the percentage of patients with mild or severe cognitive impairment, defined as failure in one-two or three or more tests, respectively ${ }^{40}$.

With regard to the 0 Outcomes in the second-and third and fourth groups, they vary considerably between studies and are numerous (Table 1 and Supplementary Table 3). Confirmed disability progression (CDP) is defined as a worsening of the EDSS (usually 1.5-step EDSS progression when starting EDSS is 0, 1-step EDSS progression for EDSS $\leq 5.5$, or 0.5-step EDSS progression for EDSS >5.5) that persists for either three or six months. It has been demonstrated that 3-month and 6-month CDP overestimate the long-term accumulation of irreversible disability by $30 \%$ and $26 \%$, respectively ${ }^{45}$. Longer disability confirmation periods (12 and 24 months), although not completely free from such bias (overestimation of $20 \%$ and $11 \%$ respectively), would be recommended to detect true, irreversible disability, with a possible little effect on the sensitivity of the progression criteria ${ }^{45}$. However, so far, no trials have used such long periods to confirm disability progression. Most trials have used both 3-month and 6month disability progression, although some recent studies, such as CARE-MS ${ }^{29}$ and $\|^{30}$, have used only the 6-month CDP outcome. If a trial uses the time to 3-month CDP (or the percentage of patients with 3-month CDP) as primary endpoint, then the time to 6-month CDP is a secondary endpoint.

The MSFC or its subtests, which are the 25 -foot Timed Walk Test (TWT), the 9-Hole Peg Test (9-HPT) (which reflects the motor impairment in the upper limbs), and the Paced Auditory Serial Addition Test (PASAT) (which reflects the speed of (auditory) 
information processing and calculation ability $)^{39}$, can be used instead of the EDSS to define the CDP. Although the training effects often seen on the PASAT could theoretically be responsible for a lower responsiveness of the MSFC than the EDSS to detect disability progression ${ }^{46}$, this is not supported by the results of the trials published so far, where MSFC-derived outcomes seem to be more sensitive than those derived from EDSS. For example, the CARE-MS $\|{ }^{30}$ or the FREEDOMS $1{ }^{47}$ trials, carried out in RRMS, or the IMPACT trial, in SPMS ${ }^{43}$, showed significant results in the MSFC but not in the EDSS. Instead, trials that showed significant effects in the EDSS, such as CARE-MS ${ }^{29}$ and the FREEDOMS ${ }^{14}$, tended to show also significant results in the MSFC.

Further attempts have been made to improve the sensitivity of MSFC and its subtests to disease progression, and therefore increase its sensitivity to treatment effects. For instance, it was suggested that only increases of at least $20 \%$ in MSFC subtests were clinically meaningful and had an acceptable signal-to-noise ratio, suggesting that clinical trials should use outcomes based on these subtests as binary metrics ${ }^{48}$. However, so far, only one phase III trial, the ARIANNA study, which compared oral atorvastatin add-on to SC interferon beta-1b in RRMS, has used this $20 \%$ cut-off to define the MSFC-related outcome measure ${ }^{40}$.

Among the outcome measures of the third group, the most widely used one is the sustained improvement in the EDSS score, which was used as a secondary outcome in

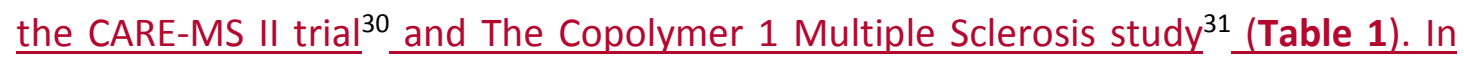
phase III trials, it has only been used when drugs were to be tested in patients with RRMS, possibly reflecting the role of acute inflammation in the development of 
disability in these patients. Quite recently, a phase II study carried out in progressive MS, the biotin study, also used the improvement of disability as an outcome measure -in particular, as a primary outcome measure ${ }^{49}$. In this study, which showed positive results, the improvement of disability was not only reflected by improvements in the EDSS score, but also in the TWT score ${ }^{49}$. Improvement was considered if there was a decrease in the EDSS of $\geq 0.5$ or $\geq 1$ points, if baseline score was between 6 and 7 or between 4.5 and 5.5, respectively, or if there was a decrease in the TWT of at least $\underline{20 \% \text {. Sustained improvement of disability as outcome measure may therefore reflect }}$ clinical changes secondary to not only remission of inflammation but also tissue regeneration, which may be expected in the new era of drugs being tested in progressive MS, such as the abovementioned biotin ${ }^{49}$, simvastatin (tested in the phase $\underline{\| \text { MS-STAT trial }}{ }^{50}$ ) or oxcarbazepine (being currently tested in the phase II PROXIMUS $\left.\underline{\text { trial }}^{51}\right)$

Composite endpoints, which are in the fourth group of disability progression measures, facilitate higher event rates and theoretically increase the sensitivity of the progression parameters, thereby reducing the length of the trial and the sample size. Besides, they theoretically reduce the risk of multiplicity and so the risk of type I error ${ }^{9}$. However, composite endpoints should be pre-specified before starting the trial and their individual components should only be tested when there is a statistically significant treatment effect for the composite, unless the components have been prespecified as outcome measures too ${ }^{9}$. A recent reanalysis of a PPMS trial showed that composite endpoints including different disability measures allows detection of larger treatment effects, then reducing the sample size needed for clinical trials ${ }^{52}$. The 
highest efficiency and event rate estimates were obtained by using a sustained disability progression endpoint confirmed by any two of the following: [EDSS and TWT] or [EDSS and 9-HPT] or [TWT and 9-HPT]. This endpoint usefully combines the logical "and" and "or" criteria, maximizing the likelihood to detect a clinical event. However, composite endpoints are only valid when the composite includes outcomes that are causally related to the treatment ${ }^{53}$.

A recent phase III trial in PPMS used as primary outcome measure the time to 3-month CDP based on a composite endpoint, defined as the presence of at least one of the following three changes: increase in EDSS ( 1 if EDSS $<5.5$ or 0.5 if EDSS $\geq 5.5$ ), increase in $\geq 20 \%$ in $9-\mathrm{HPT}$, and increase $\geq 20 \%$ in $\mathrm{TWT}^{54}$. Post-hoc re-analyses of trial data have suggested that this composite endpoint may separate MS patients with ongoing progression from those who are stable ${ }^{54}$, thereby representing an improved endpoint for disability progression trials. Another composite outcome used as secondary endpoint in a progressive MS trial ${ }^{55}$ is the time to a 3-month CDP or to a confirmed $20 \%$ worsening in the 9HPT treatment failure (Supplementary Table 3).

\section{Patient-reported outcome measures}

Patient-reported outcome measures (PROMs) are self-completed questionnaires that measure the impact of the disease on daily activities, social functioning and quality of life. In 2009, the Food and Drug Administration (FDA) published a guidance on $\mathrm{PROMs}^{9}$, which were defined as 'any report of the status of a patient's health condition that comes directly from the patient, without interpretation of the patient's response by a clinician or anyone else' ${ }^{\prime}$. In 2016, the European Medicines Agency 
defined PROMs as any data directly reported by a patient that is based on his/her perception of a disease and its treatment (www.ema.europa.eu), thereby further developing the concept of "personal perspective". The term PROM is an umbrella term, which includes evaluations of health-related quality of life, health status, wellbeing, satisfaction with treatment, adherence to treatment, and symptoms. Therefore, PROMs complement and support the outcome measures based on clinical assessments, and, as mentioned in the 2009 guidance of the FDA, they can be used in clinical trials to measure the risks of a given treatment as well as its benefits ${ }^{9,56}$.

PROMs can be divided into two groups: condition-specific and generic PROMs. In the first group, there are tools designed for MS, which cannot be extrapolated to the general population and are sensitive to detect an MS-induced change. Examples of MS-specific health-related quality of life PROMs are the 29-item MS impact scale $(\mathrm{MSIS}-29)^{57}$, the patient-reported indices in MS (PRIMUS) ${ }^{58}$, and the MS quality of life$54^{59}$. Thirteen fatigue-centred PROMs have been proposed in 20 years, and the most popular are the fatigue severity scale (FSS) ${ }^{60}$ and the fatigue impact scale (FIS) ${ }^{61}$ (Table 2). The MS-specific PROMs that measure the impact of motor impairment on daily activity, such as the Arm Index ${ }^{37}$ and the Multiple Sclerosis Walking Scale (MSWS$12)^{62,63}$, have been frequently used as trial endpoints over the last 5 years ${ }^{54,64,65}$ (Table 2). It has been suggested that a reduction of 4-6 points on the MSWS-12 is clinically meaningful ${ }^{66}$, although the MSWS-12 has also been used as a continuous measure, without any thresholding, in a symptomatic trial (i.e. the Fampridine trial) ${ }^{67}$. Many generic PROMs, such as those that focus on symptoms, such as pain, tremor, and 
spasticity, have been used in symptomatic trials in $\mathrm{MS}^{68,69}$, but a deep discussion of these is outside the scope of this review.

PROMs that in future may be further studied and validated for use in clinical trials and clinical practice are the patient-determined disease step (PDDS), which is a simple and economical scale compared with the EDSS, but correlates with it and its functional system scores ${ }^{70}$, and the subscales of both the MFIS and MSIS-29. A recent trial has included the physical subscale of the MSIS-29 as a co-primary endpoint of the study together with time to EDSS-based 6-month $\mathrm{CDP}^{65}$. This indicates that composite endpoints may be obtained by combining objective scales (e.g., EDSS) and PROMs, although the same limitations associated with the combined scores discussed above apply to these combined endpoints.

\section{Neuroimaging outcomes}

We have divided the neuroimaging outcomes used in clinical trials into: focal brain lesions, brain and spinal cord atrophy measures, and novel MR outcomes for neurodegeneration and remyelination.

\section{Focal brain lesions}

MRI measures of focal brain lesions often serves as primary endpoints in phase II trials and typically secondary outcomes in phase III trials. They are particularly relevant to trials carried out in patients with RRMS and CIS, which test the efficacy of medications targeting the inflammatory activity ${ }^{71}$ (Table 3 and Supplementary Tables 4 and 5), although they are also used in trials in progressive MS (Table 3 and Supplementary 
Table 6). The most commonly used MRI measures are based on T1 gadolinium enhancing and new T2 brain lesions, which reflect the occurrence of new inflammatory activity. In particular, Gadolinium enhancement signifies breakdown of the blood-brain barrier as a consequence of acute inflammation in the CNS. However, there is a fundamental difference between T1 gadolinium enhancing and new T2 brain lesions, since T1 gadolinium enhancing lesions are transient (average duration of 3 $\underline{\text { weeks }^{72}}$ ) and a single scan will miss cumulative new inflammation over a period of time. Instead, given the (generally) non-transient nature of the T2 lesions, 'new T2 lesions' with respect to the last scan would capture cumulative new inflammation between the last and the current scans. Nonetheless, In particular, the 'number of gadolinium-enhancing lesions' during or at the end of follow-up is the most widely used trial outcome in all phase III trials (Table 3).

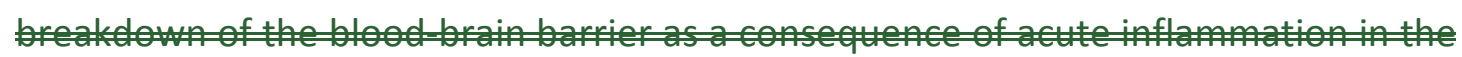
CI-.hypointense lesions are visible in both the acute phase of a lesion development (corresponding to the lesional oedema) and the chronic phase ${ }^{73,74}$; in the latter case they are called permanent black holes (PBH), which have been mostly used as a post-hoc measure of tissue destruction and recovery ${ }^{13}$.

Lesion-derived measures can be divided into three categories: (i) outcomes that measure the occurrence of new lesional activity during the trial, such as the number of new_and/or enlarging T2 lesions or new_ T1 gadolinium enhancing lesions, (ii) outcomes that quantify the total lesion volume, either T2-hyperintense, T1hypointense or gadolinium-enhancing lesion volume, and (iii) those that estimate the inflammatory activity as a binary phenomenon, such as the proportion of patients 
without gadolinium enhancing lesions. Finally, there would be a set of metrics that could be included within the first group, since they reflect new, acute lesional activity, and that are derived from the combination of different MRI measures. An example of these composite MRI measure is the number of combined unique active (CUA) lesions, which describes the total number of active lesions in the widest sense and includes all new, enlarging T2 lesions or new enhancing lesions, provided that the same focal lesion is counted only once. This endpoint was originally proposed by Paty and Li and was already used in the first clinical trials in RRMS. In CIS trials, it was used for the first time in the early 2000 by the ETOMS study ${ }^{75}$, and in SPMS trials, it was first used in the SPECTRIMS study ${ }^{76,77}$. So far, at least 13 phase III trials have used it (Table 3).

The greatest advantage of lesion-related markers is that they provide objective measures of the underlying pathology and correlate with clinical outcomes in RRMS, in particular with relapses, at least in the short/medium term ${ }^{78}$. It has been demonstrated that more than $80 \%$ of the between-trial variability in terms of treatment effects on relapses is explained by the between-trial variability in terms of treatment effects on new $\underline{\mathrm{T} 2}$ lesions on $\mathrm{MRI}^{79}$. In addition, treatment effects on relapses of phase III trials can be predicted by the treatment effects on lesion-related outcome measures in the corresponding phase II trials that used the same drug ${ }^{80}$. Another advantage of lesion-related measures is that, given their high sensitivity, they allow the comparison of two active drugs, which can be difficult when the outcome is clinical relapses. For instance, in the GATE study, which compared generic glatiramer acetate with the originally branded drug, lesion-related outcomes were used to show equivalence of the two drugs ${ }^{81}$. 
The counting of new T2 lesions can be limited by factors such as high pre-existing lesion load, suboptimal repositioning of serial scans and poor inter-observer reproducibility. Image subtraction has been proposed to overcome these issues, thus providing good visualization and quantification of both active and shrunken or resolved $\mathrm{T} 2$ lesions ${ }^{82}$. The combination of automated identification of new/enlarging lesions with automated lesion subtraction may be useful to improve costeffectiveness and reduce the risk of adverse events associated with gadolinium administration $^{83}$.

\section{Brain atrophy measures}

The rationale behind the use of brain atrophy in clinical trials is that it reflects neurodegeneration, which is the pathological process most consistently linked to accrual of disability ${ }^{84-86}$. Total brain volume/fraction is the non-lesional outcome measure most commonly used in phase III trials (Table 3). It is generally used as a secondary outcome measure in phase II and III trials, such as the FREEDOMS study ${ }^{14}$, where fingolimod was compared to placebo, or the CARE-MS $\mathrm{I}^{29}$ or $1 \mathrm{I}^{30}$ studies, where alemtuzumab was compared to interferon beta-1a. Nonetheless, it has recently been used for the first time as primary endpoint in phase $\mathrm{II}^{50}$ and phase $\mathrm{II}$-trials in secondary progressive MS (http://www.ms-smart.org, accessed on 29/0ㅌ1/2017; and https://clinicaltrials.gov/ct2/show/NCT01910259?term=MS+smart\&rank=1, accessed on 29/01ㅛ/2017), and also in the ongoing phase II ARPEGGIO trial in PPMS ${ }^{87}$. In RRMS, the treatment effect on brain atrophy correlates with the effect on disability progression over 2 years, independently of the effect on active MRI lesions ${ }^{66}$. 
There are two types of brain volume-derived metrics (Table 3 and Supplementary Tables 5 and 6): (i) metrics that calculate global brain atrophy, as either brain parenchymal volume ${ }^{88}$ or fraction ${ }^{40}$ (which is the ratio of brain parenchymal volume to the total volume within the brain surface contour), and their change over time, and (ii) metrics that estimate regional volumes, such as white matter and grey matter, and change thereof during the trial ${ }^{89}$.

The most widely used measures in the first group are the brain parenchymal fraction (BPF), a segmentation-based technique that reduces the variability caused by individual variation in brain size and has high test-retest reproducibility when compared with raw brain volume ${ }^{90}$, and the percentage brain volume change (PBVC), a registration-based difference map of brain contours over time ${ }^{91,92}$. BPF has been used in studies such as the phase II trial with natalizumab in $\mathrm{RRMS}^{93}$ or the phase II trial with interferon beta-1b in PPMS ${ }^{94}$. PBVC has been used in the phase III fingolimod trials, i.e. the TRANSFORMS ${ }^{95}$ and FREEDOMS $\mathrm{I}^{14}$ and $\mathrm{II}^{47}$ studies, and the phase III laquinimod trials, i.e. the BRAVO ${ }^{96}$ and the ALLEGRO $^{13}$ studies.

In addition to the well-known technical sources of measurement error, such as changes in magnet, gradients, coils, distortion corrections and image-contrast changes that affect tissue segmentation, global atrophy metrics are susceptible to: (i) the phenomenon of pseudo-atrophy, likely due to resolution of inflammation and oedema and especially seen in patients on active treatment with greater gadolinium- 
enhancing lesion volume at baseline ${ }^{97,98}$, (ii) physiological (circadian) variations in hydration status ${ }^{99}$, and (iii) smoking and other cardiovascular risk factors ${ }^{100}$.

The measures in the second group most commonly used are the grey and the white matter volumes. The change in the volume of CSF (normalised by the total intracranial volume) has also been used in phase III trials ${ }^{101,102}$, as an attempt to quantify indirectly loss of neural tissue. A single phase II trial used the partial (central) cerebral volume, a surrogate estimate of global atrophy ${ }^{89}$. The same trial showed that a reduction in grey matter volume over time is greater than that in the white matter, and is less affected by pseudoatrophy ${ }^{98}$, as other observational studies have also reported ${ }^{103}$. Grey matter and thalamic volumes have also been used as additional outcome measures in the phase III ALLEGRO study ${ }^{13}$. Therefore, if these partial volumes are confirmed to show a greater change over time than global measures $89,104,105$, they will result in higher sensitivity and a smaller sample size.

\section{Spinal cord atrophy}

Spinal cord atrophy is usually measured at the cervical level, and has been associated with long-term development of motor disability, not only in progressive MS but also in relapse-onset $\mathrm{MS}^{106,107}$. The rate of brain atrophy in $\mathrm{MS}$ is about $0.5 \%$ a year ${ }^{108}$, whilst that of spinal cord atrophy has been shown to be higher, up to $2.2 \%$ a year in SPMS $^{109}$, suggesting that spinal cord atrophy may be a sensitive and meaningful marker of neurodegeneration. Trials in PPMS or SPMS have used the change in cord $\operatorname{area}^{54}$ as a secondary endpoint (Supplementary Itable 7). However, there are methodological factors that affect the noise of this measurement in multi-centre 
trials, mostly related to the limited spatial resolution of current MRI scanners relative to the small cord size and cord movement. This translates into larger sample sizes than those estimated from a single centre/scanner study ${ }^{110}$. Additionally, spinal cord atrophy-related measures are calculated using semi-automated segmentation-based methods, which are subject to inter-rater variability.

\section{Novel imaging outcomes for neurodegeneration and remyelination}

New outcomes have been proposed and used over the last 5 years to detect the effect of drugs at a microscopic level. The advantage of such measures is that they are expected to be more tissue-specific for the underlying pathophysiological processes than conventional MRI measures, and, therefore, may detect changes reflecting the underlying mechanisms of damage caused by the action of the experimental medication. These novel measures may provide complementary information to that given by conventional imaging endpoints and insights into the mechanistic efficacy of the medication.

The most widely used measure is the change in magnetic transfer ratio (MTR) in the whole brain ${ }^{13,16,111}$ (Table 3 and Supplementary Table 4). MTR changes are thought to reflect the process of demyelination ${ }^{112}$ and remyelination ${ }^{113}$. Apart from whole brain MTR, regional MTR, such as grey matter, white matter and lesional MTR, have also been used (e.g., in the phase III, ALLEGRO trial in $\mathrm{RRMS}^{13}$ ).

Other measures -used mostly in the past- to show an effect of DMTs are metabolite concentrations, estimated by MR spectroscopy imaging, such as $\mathrm{N}$-Acetyl 
Aspartate ${ }^{13,114}$. Novel secondary outcome measures currently used in phase II trials in secondary progressive MS are diffusion metrics-parameters derived from NODDI (Neurite orientation dispersion and density imaging), which estimate the microstructural complexity of dendrites and axons in vivo ${ }^{115}$ and sodium imaging ${ }^{116}$ (https://clinicaltrials.gov/ct2/show/NCT02104661?term=oxcarbazepine+multiple+scl erosis\&rank=1, accessed 29/06/January-2017).

Optical Coherence Tomography (OCT) measures axonal and neuronal loss within the anterior visual pathway, which not only correlate with the visual function ${ }^{117,118}$, but also reflect whole-brain process of neurodegeneration, especially in progressive $\underline{M S}^{119}$. For that reason, it has been proposed as outcome measure in both optic neuritis $^{120}$ and non-optic neuritis MS trials, such as the PROXIMUS (add-on oral

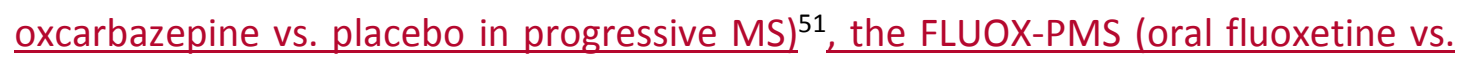
placebo in monotherapy in progressive MS) ${ }^{121}$ and the ACTiMuS (bone marrowderived cellular therapy in progressive $M S)^{122}$ trials. Please see Box 1 and Supplementary Table 8 for more details on OCT-related outcome measures.

\section{Combined clinical and MRI outcomes}

Although the use of these types of measures emerged in MS trials in 2012 with the CombiRx trial, the concept dates back to 2006, when Rio et al. showed that the absence of relapses, disability, and inflammatory activity visible in the MRI (at certain thresholds) after a given time on treatment would possibly indicate so minimal disease activity that the risk of progression over a longer follow-up was negligible ${ }^{5}$. In 2014, the outcome measure called "no evidence of disease activity" (NEDA) ${ }^{4}$ was defined as 
no relapses, no progression of disability, and no MRI activity (new/enlarging $\underline{T 2}$ lesions and T1 gadolinium enhancing lesions). It had been initially defined as "Disease Activity Freedom" (DAF) in the natalizumab AFFIRM trial ${ }^{123}$ and later re-termed as NEDA. It has been recently used in phase III (Table 3 and Supplementary Table 1) ) $^{29,30,101}$ and phase II trials ${ }^{124,125}$. NEDA has also been used to compare the efficacy of medications among trials; for example, AHSCT (autologous haemopoietic stem cell transplantation) trials have shown a greater proportion of patients reaching the NEDA status than other treatments ${ }^{126}$. Since brain volume loss reflects neurodegeneration (the main determinant of progressive disability), it has been proposed to include it in the definition of no evidence of disease activity (so-called "NEDA-4"), together with relapses, MRI disease activity and clinical progression ${ }^{127}$.

Another combined endpoint is the event-free survival ${ }^{128}$, used in AHSCT trials, which includes death as an outcome in addition to worsening of disability, relapse and new MRI lesions, suggesting that combined measures can be designed to reflect the expected efficacy and main adverse events of the drug.

The main objections to the use of these combined measures in clinical trials are that the net effect of the experimental drug on the composite metric may be difficult to interpret, if the effect on the different components is not the same, and there is uncertainty in respect to the clinical relevance for individual cases ${ }^{53,129}$.

\section{Outcomes in the clinical setting}

In this section, we describe the clinical and neuroimaging measures that are currently used in clinical practice. 


\section{Clinical measures}

In clinical practice, the most widely used clinical measures are related to the occurrence of relapses and clinical progression, generally measured with the EDSS.

\section{Relapses}

The number of relapses occurred within a given time frame, usually 6-12 months, is the clinical outcome most commonly used in clinical practice. It traditionally requireds taking a medical history (which maycould be associated with a recall bias) and inspecting the clinical notes.--The use of high-quality prospectively designed databases can allow a more precise retrieval of relapse-related data in the clinic, successfully $\underline{\text { enabling clinicians to assess treatment effects in clinical practice }}{ }^{130,131}{ }^{.}$The presence of relapses while on treatment, in combination with other factors such as EDSS increase $^{5}$ or MRI activity ${ }^{132}$, has been considered as a surrogate for future disability. Along these lines, a recently published study from the MAGNIMS group, which included 1,280 patients with RRMS on disease-modifying treatment, showed that the presence of at least 2 relapses (or 1 relapse and $\geq 3$ new T2 lesions) during the first year of treatment with interferon beta was associated with $48 \%$ risk of treatment failure, defined as a confirmed EDSS worsening ( $\geq 1$ point increase in EDSS if starting EDSS $<5.5$, or $\geq 0.5$ increase if EDSS $\geq 5.5$ ) or a switch to other therapies for lack of efficacy, and $29 \%$ risk of EDSS worsening over 3 years ${ }^{133}$.

\section{Measures of disability}


The most common measure collected in clinical practice is the EDSS, which is used in the outpatient clinics to assess the severity of clinical relapses and monitor treatment effects. This scale is based on the standard neurological examination, which is part of any clinical assessment, and clinicians are very familiar with the meaning of scores above 4.0, which are based on walking ability. Therefore, the EDSS may be easy to interpret clinically. However, as mentioned above, it has low intra- and inter-rater reproducibility, especially for patients with mild to moderate disability. Besides, the EDSS is not sensitive to important aspects of clinical progression, such as cognitive dysfunction.

The MSFC is not used in the clinic as frequently as the EDSS or as often as in clinical trials. One of the MSFC subtests, the PASAT test ${ }^{134,135}$, assesses the speed of (auditory) information processing and calculation ability, and may compensate for the fact that cognitive impairment is not captured by the EDSS. The TWT may be routinely performed in the clinical setting when assessing patients' ability to walk before and after fampridine, to know whether the patient has benefited from the drug ${ }^{136}$. However, the MSFC and its subtests have been designed to be used in clinical trials, for group analyses, rather than to be used in the clinic, at the individual level ${ }^{39}$. To use the MSFC or its components, it is required an a priori definition of a clinically meaningful change. Besides, the reference population affects the values of the MSFC z-scores, which means they cannot be easily interpreted in the clinic. Other limitations include the practice effects ${ }^{137,138}$, which may influence the PASAT, and the fact that the PASAT can be too distressful ${ }^{139}$. 
Considering the prevalence of cognitive dysfunction in MS and its impact on patients' day-to-day lives, a committee of experts on cognitive dysfunction in MS agreed on the need of regular cognitive assessments in patients with MS and proposed a brief battery to be administered in the clinic, the Brief International Cognitive Assessment for Multiple Sclerosis (BICAMS) ${ }^{140}$. This includes the Symbol Digit Modalities Test $(\mathrm{SDMT})^{141}$, which is also included in the Rao's battery ${ }^{142}$, and is the most widely used cognitive test. It measures attention and speed of information processing and lower scores have been associated with the severity of white matter damage ${ }^{143}$. It has been shown to be more valid and reliable than the PASAT, in part because it is a less distressful test ${ }^{144}$. It requires a few minutes in total to be performed and the person who administers the test does not require a specific training ${ }^{142}$. For all these reasons, it is considered the best test to be administered if the time allocated to cognitive assessment is very limited ${ }^{140}$. In addition to the SDMT, the BICAMS includes The California Verbal Learning Test (Second Edition) and The Brief Visuospatial Memory Test (Revised Version), and tests of verbal and visuospatial memory ${ }^{140}$. Apart from the SDMT and the PASAT, the remainder of the tests included in the Rao's battery can also be used in the clinic, although training of the health professional is required ${ }^{142}$. Finally, the Cogstate battery, a computerized tool made of simple rapid tests $\underline{\text { measuring processing speed, attention, working memory, executive function and }}$

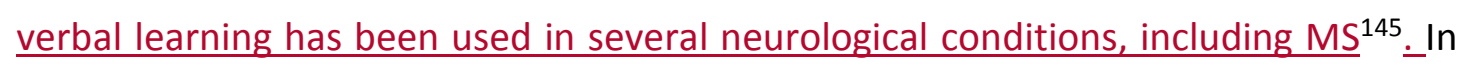
general, cognitive tests in the clinic are difficult to administer due to time constraints. Thus, more novel batteries such as the Cogstate, which can be self-administered online, are potentially more promising in clinical practice. Additionally, it is neutral to $\underline{\text { language and culture, being therefore preferable to other tests that may be influenced }}$ 
by education. Additional factors to consider are the effects of depression, anxiety and fatigue on performanceBesides, age, education, depression and anxiety, and fatigue may affect performance on all cognitive tests.

The PROMs discussed above can also be used in the clinic. In particular, the fatigue scales, such as the FSSatigue Severity $\mathrm{Scale}^{60}$, the Modified Fatigue Impact Scale $\underline{(M F I S}^{146}$ or the Visual Analogue Scale for fatigue ${ }^{147}$, may be used. Other useful PROMs are those that relate to depression, anxiety, pain or quality of life. Interestingly, in the near future, the usefulness of PROMs in the clinic may substantially increase with the help of the new technologies, since PROM-related information can be collected and displayed to clinicians electronically.

\section{Neuroimaging measures}

In this section we review the T2 lesions, which is the most commonly used response measure in the clinical setting, followed by brain atrophy and combined outcome measures, which have recently started to emerge and are therefore also discussed.

\section{$\underline{\text { Lesion-related measures }}$}

MRI has become a very usefulvital tool in clinical practice. According to international recommendations, patients should be scanned regularly, usually at least once a year $^{148,149}$, especially if they are on treatment, or even more frequently, if they are on certain treatments such as natalizumab, fingolimod or dimethyl fumarate, and considered to be at risk of John Cunningham virus (JCV)-positive progressive multifocal 
leukoencephalopathy ${ }^{150}$. However, other time frames may still be possible and it is not fully clear which is the best to adopt for routine, non-urgent MRI scans ${ }^{148,151}$. International consensus recommends to perform a brain and/or a spinal cord MRI scan when unexpected or atypical symptoms appear ${ }^{148,151}$. Ideally, when brain MRI is used for monitoring of disease activity and treatment efficacy, it should be performed on the same MRI system, using the same imaging protocol (i.e., the same pulse sequences and spatial resolution) as the reference (baseline) $\operatorname{scan}^{148}$.

The most common response measure is the number of new (or enlarging) T2 lesions, as compared with the previous scan, which is also referred as the number of active T2 lesions $^{148}$. The number of active lesions is useful to monitor treatment response, since the presence of new $\underline{\mathrm{T} 2}$ lesions while on treatment has been associated to a worse clinical outcome $e^{6,148}$ and may indicate the need for a treatment change ${ }^{6}$. The occurrence of at least 3 new T2 lesions in the first year of interferon beta therapy was associated with $27 \%$ risk of treatment failure (defined as confirmed EDSS increase or switch to other therapies for lack of efficacy) and 22\% risk of EDSS worsening over 3 years $^{133}$. A disadvantage of the number of active $T 2$ lesions as a response measure in the clinic is that it requires previous MRI scans of the patient to be available for comparison, and an experienced radiologist. Recently, the feasibility and reliability of automated lesion segmentation algorithms using clinically acquired scans has started to be assessed, showing promising results ${ }^{152}$. Therefore, in the near future, these algorithms may allow the automatic computation of total T2 lesion load in the clinic, potentially improving the monitoring of patients with MS. 
Another MRI measure used in the clinic is the number of Gd-enhancing lesions, which provides information on acute inflammation and does not require the availability of previous MRI scans. The predictive value of Gd-enhancing lesions seems to be equivalent to that of the presence of new/enlarged (active) T2 lesions ${ }^{148}$. Additionally, the enhancement, as happens with the presence of new lesions, has a role in demonstrating the dissemination in time, as defined in the revised McDonald eriteria ${ }^{21}$. For the dissemination in space criteria, the recent MAGNIMS consensus guidelines ${ }^{146}$ for the MRI criteria for the diagnosis of MS have suggested to include (i) cortical lesions (together with the juxta-cortical lesions); and (ii) optic nerve lesions. Yet at present, these lesions are looked for in selected, ad-hoc cases.

Over longer periods of observation, though, the number of new T2 lesions may be preferable to Gd-enhancing lesions to detect subclinical disease activity, as the latter only depicts disease activity in recent weeks. Other reasons for this include the higher costs associated to gadolinium usage and the fact that gadolinium infusions entail some-rare medical risks, the most serious of which is the nephrogenic systemic fibrosis, although the risk may depend on the type of the gadolinium-containing contrast media ${ }^{153}$. Gadolinium can also deposit in the brain ${ }^{154}$ yet the clinical consequences of this deposition remain unknown. Gadolinium administration is not recommended in routine MRI safety monitoring of patients receiving natalizumab ${ }^{155}$.

\section{Brain atrophy and other MRI measures}

The use of atrophy in the clinic is currently controversial ${ }^{156-158}$. Although the contribution of brain atrophy to clinical and cognitive deficits is well-established at a 
group level ${ }^{148}$, there are several factors that may limit the application of atrophy in the clinical setting. These are: the lack of normative values for brain volume changes in healthy individuals and in patients with MS, the intra-individual variability, due to physiological variations (for example, dehydration, alcohol consumption), the presence of co-morbidities and disease-related factors, such as the initiation of a DMT, which may induce "pseudoatrophy"97,103,148. There a number of current techniques in development to try to overcome these issues: Jacobian integration ${ }^{159}$ or lateral ventricle volume estimation ${ }^{160}$ using T1-weighted or T2-weighted images, respectively, are being developed to improve the reliability of atrophy metrics in the clinic. It is important to bear in mind that differences in the MRI hardware and software packages used for analysis or processing can generate variability in brain atrophy measures ${ }^{148}$. Additionally, $\div$ MRI scanner upgrades or replacements can make the images acquired at different time points non-less comparable ${ }^{161}$. Ideally, of course, the same MS patient should be scanned on the same scanner and with the same protocol, whenever possible.

\section{Combined clinical and MRI measures}

A MAGNIMS study mentioned above showed that combining MRI activity with clinical relapses during the first year of treatment with interferon may identify patients who have a high risk of treatment failure and EDSS worsening in the short term ${ }^{133}$. In actual fact, escalation from first line DMT to a second line DMT is routinely advised in the clinical setting as a consequence of clinical and radiological evidence of disease activity. 
There is no strong evidence to support the use of NEDA in clinical practice. In 2015 Rotstein et al. found, in a longitudinal study carried out in 219 patients, that those who maintained NEDA for 2 years had a very high probability (78.3\%) of not showing any disability progression (defined as an increase in EDSS of $>0.5$ points), at 7 years of follow-up. However, a recent study that included 517 consecutive MS patients has found that achieving NEDA after the first two years of follow-up was not associated to a better prognosis at 10 -year follow-up ${ }^{162}$. Although this was an observational study carried out in a heterogeneous cohort, where not all patients were on treatment (which may have been adjusted based on MRI and clinical findings), NEDA might not be a useful measure to predict a long-term outcome. In fact, it is likely that despite its high positive predictive value, NEDA has a low negative predictive value, so losing NEDA during the follow-up does not necessarily mean that prognosis is significantly worse, whereas maintaining NEDA is definitely a good prognostic marker. The implementation of NEDA-4, which includes brain atrophy, in the clinical setting is associated with the limitations described above and has not been validated for use in individual patients.

\section{Translation from Trials to Clinical usage}

We have demonstrated in the two sections above that most outcome measures used in clinical trials are not used in routine practice, and when they are, their use is limited and simplified. This is because in the clinical trials they are used for investigating drug effects at a population level, whilst in the clinical setting they are employed at the 
individual level to assess the response to the medication (response measure), monitor patients (monitoring measure), or guide treatment decisions. In this section, we will compare the outcomes in clinical trials versus those used in the clinic. Although a translation of outcome measures used to demonstrate the effects of the drug to the clinical setting should be sought, there are elements in the clinical practice that go beyond treatment efficacy and influence patient management, such as patient's perception of risks and patient's priorities. An attractive field of outcome measure which may overcome some barriers to the translation of outcome measures from trials to the clinical setting, such as the lack of time in the outpatient clinics, concerns the development of novel outcome measures driven by the introduction of electronic devices.

\section{Outcomes in clinical trials versus monitoring in the clinic}

Clinical or MRI outcome measures in clinical trials must be sensitive enough to be able to detect subtle, though highly relevant, treatment changes. This is especially important when the trial aims to compare a new drug not with placebo, but with another active drug ${ }^{39}$. In clinical trials, if the outcome measures are specific but not too sensitive, there may be a high risk of a falsely negative result, ultimately implying that a potentially efficacious drug may never be launched. Response measures in the clinic, instead, should probably be more specific than sensitive, since the consequences of prematurely (or incorrectly) starting or stopping a drug may have harmful consequences for the patient. 
In clinical trials, clinical and MRI outcomes do not need to be meaningful at the individual level, as far as they are meaningful at the group level. For example, the outcome 'changes in MSFC z-scores' is only meaningful at the group level, and its usefulness stems from the comparison between treatment groups. In particular, it has been suggested that an increase in at least $20 \%$ in MSFC score or its subscores is a clinically relevant increase ${ }^{48}$. Instead, in the clinic, any type of monitoring instrument (or response measure) must be meaningful at the individual level. Importantly, in both clinical trials and the clinical setting, outcomes must reflect relevant functional or structural/pathological aspects of the condition and must be reproducible.

Regarding combined outcomes, whereas they have been extensively and successfully used in clinical trials, their use in the clinic will again depend on their meaningfulness at the individual level. Some of these combined outcomes, such as NEDA, have mainly been used in the trials, although they could be valid at the individual level and used in the clinic. In fact, when the factors associated with treatment response started to be defined $^{5}$, the underlying concept was the same as NEDA, although with a less restrictive threshold.

In relation to PROMs, their implementation in the clinic may be hampered by their inter and intra-patient variability. In clinical trials, this high variability may be compensated by large numbers. Further limitations for the use of PROMs in the clinic include that they can be time-consuming, that there is a very large number of measuring tools available without a clear evidence of superiority of one over the 
others, and that the large amount of information that is produced needs to be interpreted and turned into useful data.

Another difference between outcomes in clinical trials and in the clinic is that in clinical trials there seems to be a trend towards a greater number of outcomes used over time (Figure 2a), whereas this is not happening in the clinic, where the EDSS score has been dominant for long time already. Interestingly, this increase in the number of trial endpoints is accompanied by a clear increase in the number of participants per trial (Figure $\mathbf{2 b}$ ), which all together may be considered as an attempt to increase the power of the trial to detect a treatment effect, without prolonging the trial duration (Figure 2c).

Finally, we need to acknowledge that patients and clinicians may have a different perspective on what outcomes are relevant and desirable. For example, a comparison of the opinions and judgements of clinicians with those of patients utilising the shortform-36 showed that patients tend to prioritise general health and vitality, mental health, and emotional role limitation, whilst clinicians consider that physical disability, bodily pain and social functions are more important to the patient ${ }^{163}$. Undoubtedly, these are also factors that need to be taken into account when translating outcomes from trial to the clinic setting. Ultimately holistic approachesThus, father holistic approaches-accommodating both patients' and clinicians' priorities ${ }_{2}$ are probably preferred in the clinical setting, whereas this may not be a priority in clinical trials. 


\section{Conclusions}

There are now over a dozen agents that can reduce the inflammatory component of MS, but there is an unmet and urgent need to treat progressive MS and promote tissue repair and neuroprotection. The availability of clinical and imaging measures in trials is of the utmost importance to ensure the detection of drug efficacy - nowhere more needed than in phase II trials of progression. The choice of the best set of outcomes for a given trial may be difficult because of the large amount of possible response measures described and used in the literature. Yet all trials should surely include clinical measures of disease progression, ideally based on the EDSS, for which there is a high experience, and other motor and/or cognitive measures, for which there is less experience, but which potentially have a higher sensitivity to capture subtle but relevant changes in disability. Besides, $t$ The time periods used to decide confirmed disability progression should be as long as possible, even 12 months if possible. Neuroimaging outcomes should include more traditional measures such as those related to lesion load, and also measures of brain atrophy. The inclusion of more novel measures is encouraged and their choice will possibly depend on the mechanism of action of the drug or the mechanistic research question that needs to be answered.

In the clinic, the choice of response measures determines the decisions about treatments and patient management. Although it would be ideal to use in the clinic the same tools to measure treatment response as those used in the clinical trial that led to licencingdrug being licenced, at present, most of the endpoints used in trials cannot be used as response measures in the clinical setting. This is due to technical, financial and logistic barriers, such as the time required to obtain these measures, 
training/standardisation, and the fact that their clinical meaning, when used at the individual level, is a favourable outcome in the long-run are lacking.

The use of PROMs and combined measures is important in both settings, since they capture the impact (and effects) of the intervention on clinical disability, MRI parameters, daily activities and quality of life. Further studies are needed to assess the reliability, accuracy and robustness of the combination of PROMs and objective (clinical and neuroimaging) measures, with the potential to comprehensively capture the intrinsic multidimensional nature of MS.

\section{$\underline{\text { Review criteria }}$}

For this review paper, we performed searches in PubMed and www.clinical.trials.gov using the following search terms: 'multiple sclerosis', 'phase trial', 'EDSS', 'progression', 'relapse rate', 'MRI', 'neuroimaging', 'OCT', 'PROMS', 'cognition' (clinical trials sections); and 'multiple sclerosis', 'EDSS', 'progression', 'relapse rate', 'MRI', 'neuroimaging', 'OCT', 'PROMS', 'cognition', 'electronic devices'. We did not include any date limitations (the last date that we searched was June 2017). Papers were included in this review only if they were written in English. For the clinical trial section, only phase II or phase III controlled trials were included (uncontrolled and/or phase $0 / 1$ trials were not included). 


\section{Additional elements of the article}

Tables: 3

- Table 1: Relapse-related and progression-related outcome measures used in phase III trials

- Table 2. Patient-reported outcome measures used as phase III trial endpoints

- Table 3: MRI outcome measures used in phase III trials

- Table 4: Strengths and weaknesses of outcome measures

\section{Boxes: 1}

\section{- Box 1: Novel and future outcome measures}

- Box 21: Main clinical and neuroimaging outcomes and outcome measures used in the clinical setting

Figures: 2

- Figure_1: Number of phase III trials over time in relapsing and progressive MS

- Figure 2: Trends over time in phase III trials: 2a: Evolution of number of trial endpoints over time; $2 \mathrm{~b}$ : Evolution of number of participants per trial over time; 2c: Evolution of trial duration over time

\section{Supplementary tables: 7}

- Supplementary table 1: Clinical outcomes in phase III trials with relapsing MS

- Supplementary table 2: Clinical outcomes in phase III trials with CIS

- Supplementary table 3: Clinical outcomes in phase III trials with progressive MS

- Supplementary table 4: Brain MRI outcomes in phase III trials with relapsing MS 
- Supplementary table 5: Brain MRI outcomes in phase III trials with CIS

- Supplementary table 6: Brain MRI outcomes in phase III trials with progressive MS

- Supplementary table 7: Trials with spinal cord MRI outcomes

\section{Links to web sites}

1. MS International Federation:

http://www.msif.org

2. NICE guidelines for MS:

https://www.nice.org.uk/guidance/cg186?unlid=719853888201626182413

3. $\mathrm{NIH}$ :

http://www.ninds.nih.gov/disorders/multiple sclerosis/multiple sclerosis.ht $\underline{\mathrm{m}}$

4. Clinical trials.gov:

https://clinicaltrials.gov

5. Progressive MS Alliance:

http://www.progressivemsalliance.org/about-us/2015-progress-report/ 


\section{Tables}

Table 1. Main relapse-related and progression-related outcome measures used in phase III trials

\begin{tabular}{|c|c|c|c|}
\hline \multirow[b]{2}{*}{ Outcome measure } & \multicolumn{2}{|c|}{ Number of trials } & \multirow{2}{*}{$\begin{array}{c}\text { Trials/References } \\
\text { (in alphabetical order) } \\
\text { (*: it indicates the outcome measure was } \\
\text { the primary outcome) }\end{array}$} \\
\hline & $\begin{array}{l}\text { Primary } \\
\text { outcome* }\end{array}$ & $\begin{array}{c}\text { Primary or } \\
\text { secondary } \\
\text { outcome }\end{array}$ & \\
\hline \multicolumn{4}{|c|}{ Relapse-related outcome measures - CIS trials } \\
\hline Time to CDMS & $6 *$ & 7 & $\begin{array}{l}\text { BENEFIT*21, } \text { CHAMPS }^{* 164}, \text { ETOMS }^{* 75}, \\
\text { ORACLE MS }{ }^{* 165}, \text { PreCISe }^{* 88}, \text { REFLEX }^{22}, \\
\text { TOPIC } * 23\end{array}$ \\
\hline$\%$ CDMS & 0 & 5 & $\begin{array}{l}\text { BENEFIT }^{21}, \text { CHAMPS }^{164}, \text { ETOMS }^{75}, \text { REFLEX }^{22}, \\
\text { TOPIC }^{23}\end{array}$ \\
\hline Time to McDonald MS & $2 *$ & 3 & BENEFIT $^{* 21}$, REFLEX $^{* 22}$, TOPIC $^{23}$ \\
\hline$\%$ McDonald MS & 0 & 3 & BENEFIT $^{21}$, REFLEX $^{22}$, TOPIC $^{23}$ \\
\hline \multicolumn{4}{|c|}{ Relapse-related outcome measures - MS trials } \\
\hline $\begin{array}{l}\text { Time to confirmed } \\
\text { relapse }\end{array}$ & $1 *$ & 18 & $\begin{array}{l}\text { BEYOND }^{11}, \text { CLARITY }^{166}, \text { CombiRx }^{101}, \\
\text { CONFIRM }^{167}, \text { DEFINE }^{111} \text {, EudraCT 2006- } \\
\text { O04937-13 }^{168}, \text { EUSPMS }^{169}, \text { EVIDENCE }^{170}, \\
\text { FREEDOMS }^{14}, \text { GALA }^{171}, \text { NASPMS }^{41}, \text { PRISMS }^{17} \text {, } \\
\text { REGARD }^{* 172}, \text { SIMCOMBIN }^{173} \text {, } \\
\text { SPECTRIMS }^{76,77}, \text { TEMSO }^{102} \text {, The copolymer } 1 \\
\text { multiple sclerosis study } \\
\text { study } \\
\text { stue Nordic SPMS }\end{array}$ \\
\hline $\begin{array}{l}\text { Time to confirmed } \\
\text { relapse or permanent } \\
\text { treatment } \\
\text { discontinuation }\end{array}$ & $1^{*}$ & 1 & TENERE $^{15}$ \\
\hline ARR & $23 *$ & 41 & 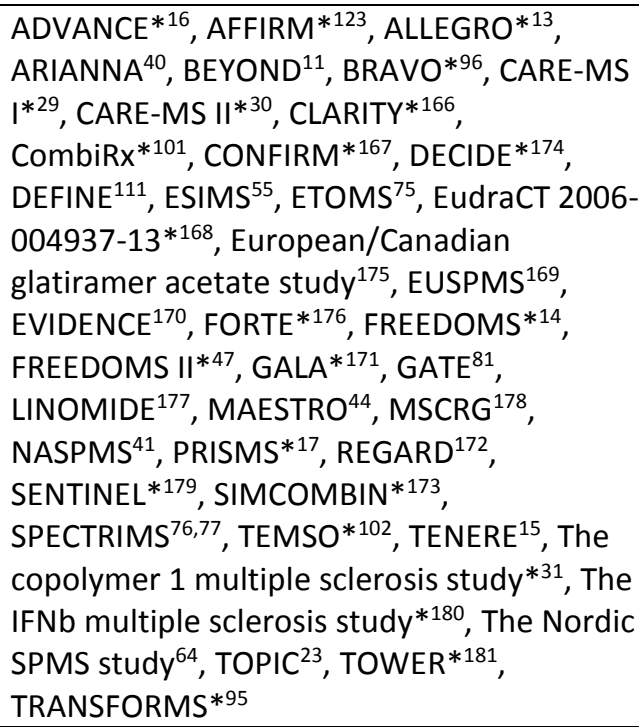 \\
\hline ARSR & 0 & 6 & $\begin{array}{l}\text { ALLEGRO }^{13}, \text { BEYOND }^{11}, \text { GALA }^{171}, \text { MAESTRO }^{44} \text {, } \\
\text { PRISMS }^{17}, \text { SPECTRIMS }^{66,77} \text {, The IFNb multiple } \\
\text { sclerosis study }^{180}\end{array}$ \\
\hline$\%$ at least one relapse & $1^{*}$ & 9 & $\begin{array}{l}\text { ADVANCE }^{16}, \text { BEYOND }^{11}, \text { CombiRx }^{101}, \\
\text { CONFIRM }^{167}, \text { DEFINE }^{* 111}, \text { ESIMS }^{55}, \text { EudraCT }^{15} \\
\text { 2006-004937-13 }\end{array}$ \\
\hline
\end{tabular}




\begin{tabular}{|c|c|c|c|}
\hline$\%$ relapse free & 2* & 28 & 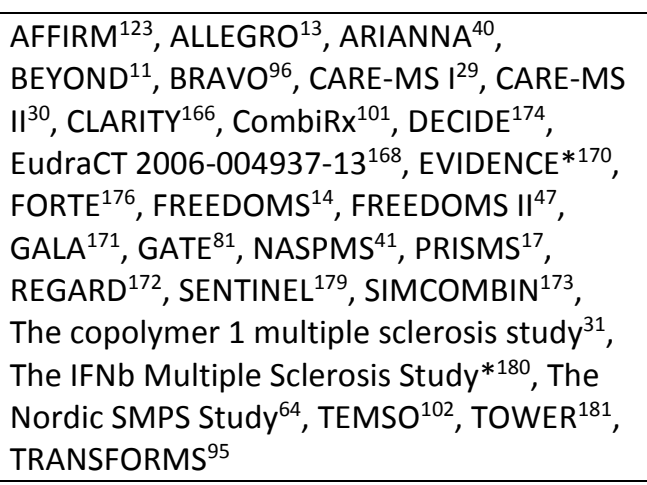 \\
\hline $\begin{array}{l}\text { Other relapse-related } \\
\text { measures: mean } \\
\text { annualised rate of } \\
\text { relapses requiring } \\
\text { steroids, relapse risk*, } \\
\text { time between first and } \\
\text { second relapse }\end{array}$ & 1* & 2 & BEYOND*11, SPECTRIMS 76,77 \\
\hline \multicolumn{4}{|c|}{ Progression-related outcome measures } \\
\hline Change in EDSS & 0 & 21 & 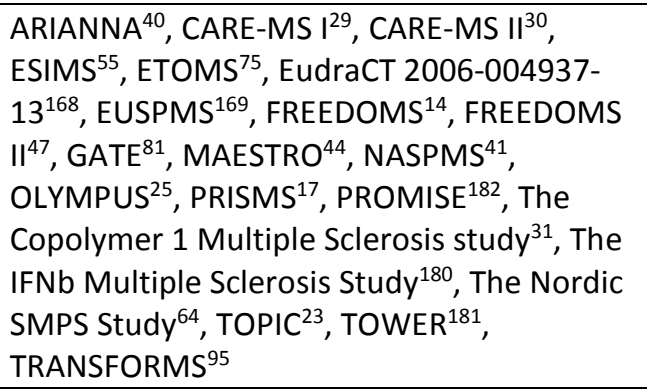 \\
\hline $\begin{array}{l}\text { Change in MSFC or its } \\
\text { subscores (PASAT, } \\
\text { TWT, 9HPT) }\end{array}$ & 1* & 11 & 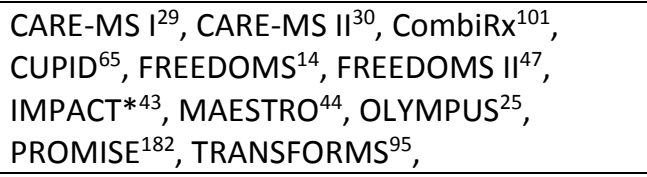 \\
\hline $\begin{array}{l}\text { Change in other clinical } \\
\text { scales (physical } \\
\text { disability) }\end{array}$ & 0 & 3 & $\begin{array}{l}\text { ETOMS }^{75}, \text { PRISMS }^{17} \text {, The Nordic SMPS } \\
\text { Study }{ }^{64}\end{array}$ \\
\hline $\begin{array}{l}\text { Change in other clinical } \\
\text { scales (cognitive } \\
\text { disability) }\end{array}$ & 0 & 2 & IMPACT $^{43}$, MAESTRO $^{44}$ \\
\hline$\%$ of $3 \mathrm{~m}-\mathrm{CDP}$ in EDSS & $2 *$ & 23 & $\begin{array}{l}\text { ADVANCE }^{16}, \text { AFFIRM }^{* 123}, \text { ALLEGRO }^{13}, \\
\text { BEYOND }^{11}, \text { BRAVO }^{96}, \text { CONFIRM }^{167}, \\
\text { DECIDE }^{174}, \text { DEFINE } \\
\text { EudraCT } 2006-004937-13^{168}, \text { EUSPMS }^{55}, \text { ETOMS }^{75}, \\
\text { INFORMS }^{54}, \text { LINOMIDE }^{177}, \text { MSCRG }^{178}, \\
\text { OLYMPUS }^{25}, \text { PROMISE }^{182}, \text { SENTINEL }^{* 179}, \\
\text { SIMCOMBIN }^{173}, \text { SPECTRIMS }^{76,77}, \text { TEMSO }^{102} \\
\text { The Copolymer } 1 \text { Multiple Sclerosis study } \\
\text { TOPIC }\end{array}$ \\
\hline $\begin{array}{l}\text { \% free from } 3 m-C D P \text { in } \\
\text { EDSS }\end{array}$ & 0 & 7 & 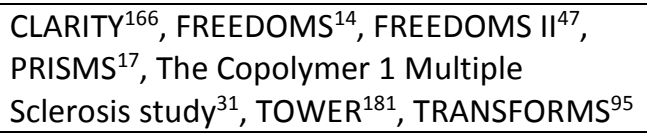 \\
\hline$\%$ of $6 \mathrm{~m}-\mathrm{CDP}$ in EDSS & 0 & 10 & 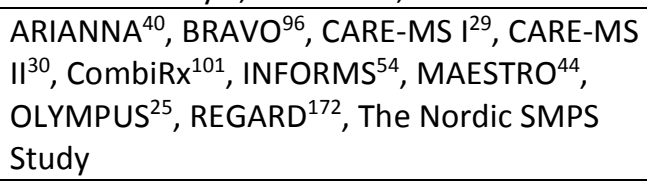 \\
\hline $\begin{array}{l}\% \text { free from } 6 \mathrm{~m}-\mathrm{CDP} \text { in } \\
\text { EDSS }\end{array}$ & 0 & 2 & FREEDOMS $^{14}$, FREEDOMS $\|^{47}$ \\
\hline
\end{tabular}




\begin{tabular}{|c|c|c|c|}
\hline $\begin{array}{l}\text { \% sustained } \\
\text { improvement in EDSS }\end{array}$ & 0 & 2 & $\begin{array}{l}\text { CARE-MS } \|^{30}, \text { The Copolymer } 1 \text { Multiple } \\
\text { Sclerosis study }\end{array}$ \\
\hline $\begin{array}{l}\% 3 \mathrm{~m}-\mathrm{CDP} \text { in MSFC } \\
\text { subscores }\end{array}$ & 0 & 2 & ESIMS $^{55}$, INFORMS $^{54}$ \\
\hline $\begin{array}{l}\% 6 \mathrm{~m}-\mathrm{CDP} \text { in MSFC } \\
\text { subscores }\end{array}$ & 0 & 1 & INFORMS $^{54}$ \\
\hline $\begin{array}{l}\% \text { with } 20 \% \text { worsening } \\
\text { in MSFC }\end{array}$ & 0 & 1 & ARIANNA $^{40}$ \\
\hline Time to EDSS 7.0 & 0 & 1 & EUSPMS $^{169}$ \\
\hline $\begin{array}{l}\text { Time to } 3 \mathrm{~m}-\mathrm{CDP} \text { in } \\
\text { EDSS }\end{array}$ & $8^{*}$ & 22 & 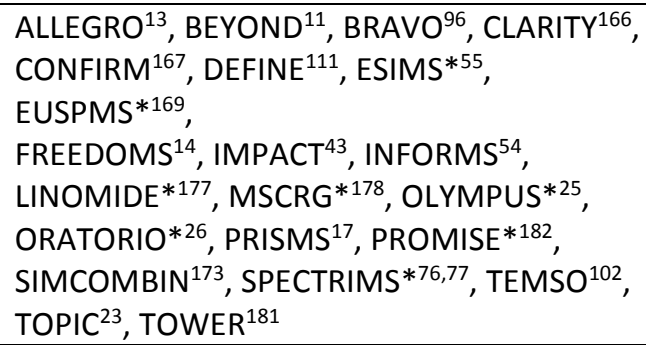 \\
\hline $\begin{array}{l}\text { Time to } 6 \mathrm{~m}-\mathrm{CDP} \text { in } \\
\text { EDSS }\end{array}$ & 6* & 12 & 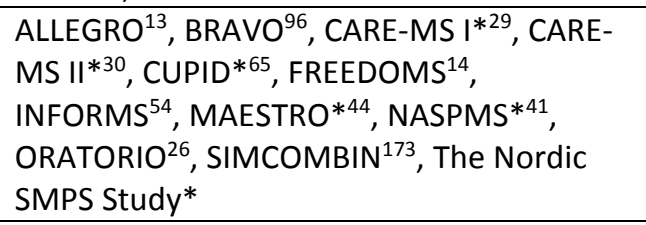 \\
\hline $\begin{array}{l}\text { Time to } 3 \mathrm{~m}-\mathrm{CDP} \text { in } \\
\text { MSFC subscores }\end{array}$ & 0 & 2 & ESIMS $^{55}$, INFORMS $^{54}$ \\
\hline $\begin{array}{l}\text { Time to } 6 \mathrm{~m}-\mathrm{CDP} \text { in } \\
\text { MSFC subscores }\end{array}$ & 0 & 1 & INFORMS $^{54}$ \\
\hline $\begin{array}{l}\text { Clinical scores at } \\
\text { follow-up }\end{array}$ & 0 & 4 & $\begin{array}{l}\text { ALLEGRO }^{13} \text {, EUSPMS } \\
\text { Copolymer } 1 \text { Multiple Sclerosis study }{ }^{17} \text {, The } \\
\text { Copoly }\end{array}$ \\
\hline $\begin{array}{l}\text { Combined disability } \\
\text { outcomes (including } \\
\text { NECA) }\end{array}$ & $1^{*}$ & 5 & $\begin{array}{l}\text { CARE-MS }\left.\right|^{29}, \text { CARE-MS } \|^{30}, \text { CombiRx }{ }^{101}, \\
\text { ESIMS }^{55}, \text { INFORMS } * 54\end{array}$ \\
\hline
\end{tabular}

Footnote table 1 . The primary endpoint of the ARIANNA study ${ }^{40}$ was the changes in brain volume fraction (i.e. this study did not have a clinical primary endpoint). Abbreviations: ARR: annualised relapse rate; ARSR: annualised rate of severe relapses; CDMS: clinically defined multiple sclerosis; CDP: confirmed disability progression; EDSS: expanded disability status scale; 9HPT: nine-hole peg test; MSFC: multiple sclerosis functional composite; NECA: No evidence of clinical activity; PASAT: paced auditory serial addition test; TWT: 25 -foot timed walk test. 
Table 2. Main patient-reported outcome measures used as phase III trial endpoints

\begin{tabular}{|l|l|l|}
\hline Outcome measure & Number of trials & \multicolumn{1}{c|}{$\begin{array}{c}\text { Trials/References } \\
\text { (in alphabetical order) }\end{array}$} \\
\hline Arm index & 2 & PRISMS $^{17}$, The Nordic SMPS Study \\
\hline PRIMUS & 1 & INFORMS $^{54}$ \\
\hline EQ-5D/MSQoL-54 & 4 & BENEFIT $^{21}$, FREEDOMS II $^{47}$, INFORMS $^{54}$, MAESTRO $^{44}$ \\
\hline FIS & 5 & INFORMS $^{54}$, TEMSO $^{102}$, TENERE $^{15}$, TOPIC $^{23}$, TOWER $^{181}$ \\
\hline MSWS-12 & 2 & CUPID $^{65}$, INFORMS $^{54}$ \\
\hline MSIS-29 & 2 & CUPID $^{65}$, DECIDE $^{174}$ \\
\hline SF-36 & 1 & TOWER $^{181}$ \\
\hline TSQM & 1 & TOWER $^{181}$ \\
\hline
\end{tabular}

Footnote table 2. Abbreviations: FIS (or UFIS): Unidimensional Fatigue Impact Scale; MSIS-29: Multiple Sclerosis Impact Scale - 29 items; MSWS-12: Multiple Sclerosis Walking Scale; SF-36: Short Form 36 Health Survey; PRIMUS: Patient-Reported Indices for Multiple Sclerosis; TSQM: Treatment Satisfaction Questionnaire for Medication, with domains for Effectiveness, Side-Effects, Convenience and Global Satisfaction. 
Table 3. Main MRI outcome measures used in phase III trials

\begin{tabular}{|c|c|c|}
\hline Outcome measure & $\begin{array}{l}\text { Number } \\
\text { of trials }\end{array}$ & $\begin{array}{c}\text { Trials/References } \\
\text { (in alphabetical order) }\end{array}$ \\
\hline \multicolumn{3}{|c|}{ T2-lesion-related outcome measures } \\
\hline \# new T2 lesions & 8 & $\begin{array}{l}\text { AFFIRM }^{123}, \text { BENEFIT }^{21} \text {, BEYOND } \\
\text { Glatiramer Acetate Study, FORTE }^{176}, \text { IMPACT }^{43}, \text { PreCISe }^{88} \text {, The } \\
\text { IFNb Multiple Sclerosis Study }{ }^{180}\end{array}$ \\
\hline $\begin{array}{l}\text { \# enlarging T2 } \\
\text { lesions }\end{array}$ & 1 & AFFIRM $^{123}$ \\
\hline $\begin{array}{l}\text { \# new or enlarging } \\
\text { T2 lesions }\end{array}$ & 28 & 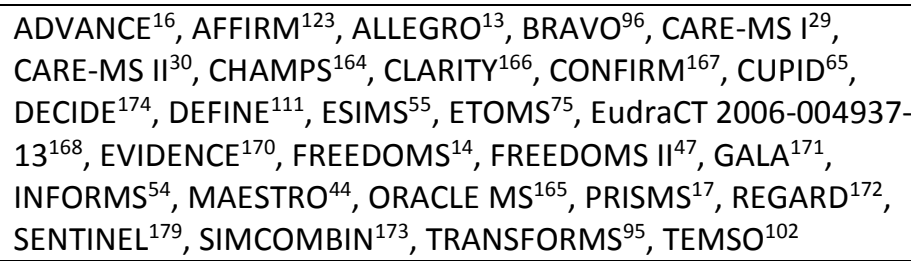 \\
\hline $\begin{array}{l}\text { Change in \#T2 } \\
\text { lesions }\end{array}$ & 4 & CombiRx ${ }^{101}$, PreCISe $^{88}$, TEMSO $^{102}$, TOPIC $^{23}$ \\
\hline $\begin{array}{l}\text { Change in T2 lesion } \\
\text { volume }\end{array}$ & 33 & 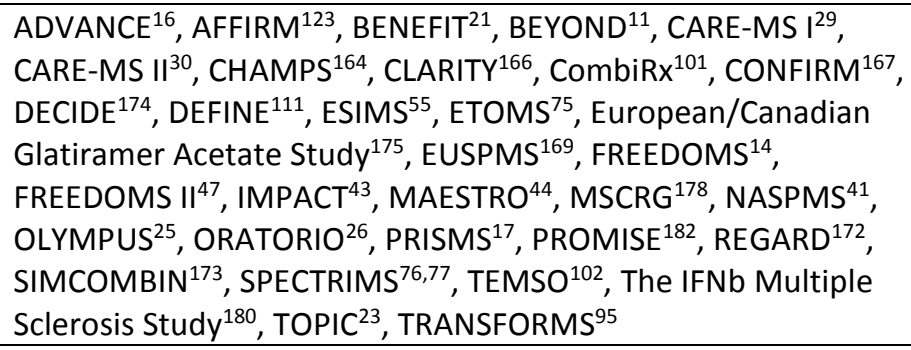 \\
\hline \multicolumn{3}{|c|}{ Gadolinium-enhancing lesion-related outcome measures } \\
\hline $\begin{array}{l}\text { \# Gd-enhancing T1 } \\
\text { lesions at follow-up }\end{array}$ & 36 & 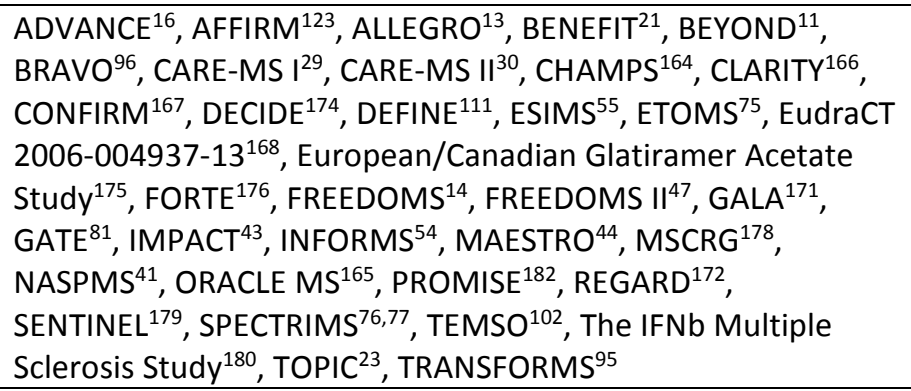 \\
\hline $\begin{array}{l}\text { \% patients with Gd- } \\
\text { enhancing lesions } \\
\text { at follow-up }\end{array}$ & 9 & $\begin{array}{l}\text { ARIANNA }{ }^{40}, \text { CLARITY }^{166}, \text { FREEDOMS }^{14}, \text { FREEDOMS II }^{47} \\
\text { INFORMS }^{54}, \text { LINOMIDE }^{177,183}, \text { REGARD }^{172}, \text { TEMSO }^{102} \\
\text { TRANSFORMS }^{95}\end{array}$ \\
\hline $\begin{array}{l}\text { Volume of Gd- } \\
\text { enhancing lesions } \\
\text { at follow-up }\end{array}$ & 11 & $\begin{array}{l}\text { AFFIRM }^{123}, \text { BENEFIT }^{21}, \text { BEYOND }^{11}, \text { CONFIRM }^{167}, \text { DEFINE }^{111}, \\
\text { European/Canadian Glatiramer Acetate Study }{ }^{175}, \text { IMPACT }^{43} \text {, } \\
\text { MSCRG }^{178}, \text { REGARD }^{172}, \text { TOPIC }^{23}, \text { TRANSFORMS }^{95}\end{array}$ \\
\hline \multicolumn{3}{|c|}{ Non-enhancing T1 lesion-related outcome measures } \\
\hline $\begin{array}{l}\text { \# new non- } \\
\text { enhancing T1 } \\
\text { lesions }\end{array}$ & 14 & $\begin{array}{l}\text { ADVANCE }^{16}, \text { AFFIRM }^{123}, \text { ALLEGRO }^{13}, \text { BENEFIT }^{21}, \text { CLARITY }^{166} \\
\text { CONFIRM }^{167}, \text { CUPID }^{65}, \text { DECIDE }^{174}, \text { DEFINE }^{111}, \text { GALA }^{171} \\
\text { INFORMS }^{54}, \text { TEMSO }^{102}, \text { TOPIC }^{23}, \text { REGARD }^{172}\end{array}$ \\
\hline $\begin{array}{l}\text { Change in T1 lesion } \\
\text { volume }\end{array}$ & 14 & 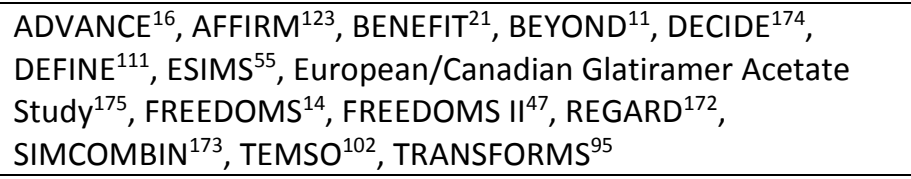 \\
\hline $\begin{array}{l}\text { Change in \# T1 } \\
\text { lesions }\end{array}$ & 1 & PreClSe $^{88}$ \\
\hline $\begin{array}{l}\text { Outcomes related } \\
\text { to permanent black } \\
\text { holes }\end{array}$ & 1 & ALLEGRO $^{13}$ \\
\hline
\end{tabular}




\begin{tabular}{|c|c|c|}
\hline $\begin{array}{l}\text { Change in ratio } \\
\mathrm{T} 1 / \mathrm{T} 2 \text { volume }\end{array}$ & 2 & AFFIRM $^{123}$, ESIMS $^{55}$ \\
\hline $\begin{array}{l}\# \text { combined unique } \\
\text { active lesions }\end{array}$ & 13 & 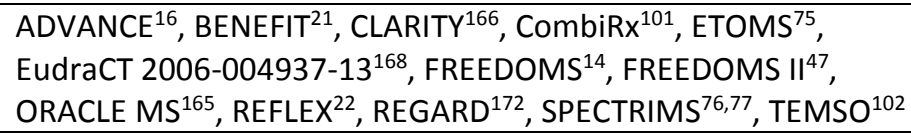 \\
\hline $\begin{array}{l}\text { Combined lesional } \\
\text { volume }+ \text { CSF } \\
\text { volume }\end{array}$ & 1 & CombiRx $x^{101}$ \\
\hline \multicolumn{3}{|c|}{ Non-lesion-related MRI outcome measures } \\
\hline $\begin{array}{l}\text { Change in whole- } \\
\text { brain } \\
\text { volume/fraction }\end{array}$ & 25 & 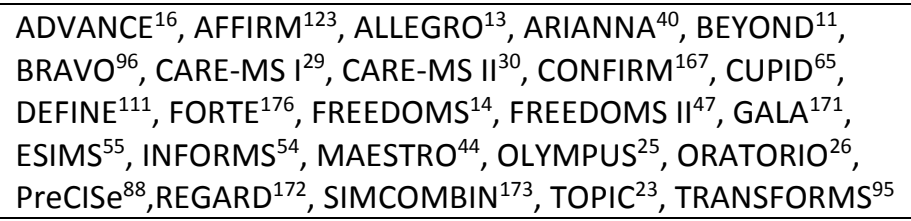 \\
\hline $\begin{array}{l}\text { Change in GM } \\
\text { volume/fraction }\end{array}$ & 3 & ALLEGRO $^{13}$, CombiRx $^{101}$, TEMSO $^{102}$ \\
\hline $\begin{array}{l}\text { Change in WM } \\
\text { volume/fraction }\end{array}$ & 4 & ALLEGRO $^{13}$, CombiRx ${ }^{101}$, CUPID $^{65}$, TEMSO $^{102}$ \\
\hline $\begin{array}{l}\text { Change in thalamic } \\
\text { volume }\end{array}$ & 1 & ALLEGRO ${ }^{13}$ \\
\hline $\begin{array}{l}\text { Change in whole } \\
\text { brain MTR }\end{array}$ & 4 & ADVANCE $^{16}$, ALLEGRO $^{13}$, CONFIRM $^{167}$, DEFINE $^{111}$ \\
\hline Change in WM MTR & 1 & ALLEGRO $^{13}$ \\
\hline Change in GM MTR & 1 & ALLEGRO $^{13}$ \\
\hline $\begin{array}{l}\text { Change in T2 lesion } \\
\text { MTR }\end{array}$ & 1 & ALLEGRO $^{13}$ \\
\hline $\begin{array}{l}\text { Changes in the ratio } \\
\text { NAA/creatinine }\end{array}$ & 1 & ALLEGRO $^{13}$ \\
\hline \multicolumn{3}{|c|}{ Combined MRI and clinical outcomes } \\
\hline $\begin{array}{l}\text { NEDA (no evidence } \\
\text { of disease activity) }\end{array}$ & 3 & CARE-MS ${ }^{29}$, CARE-MS $\|^{30}$, CombiRx ${ }^{101}$ \\
\hline
\end{tabular}

Footnote table 3. Abbreviations: CSF: cerebrospinal fluid; Gd: gadolinium; MTR: magnetisation transfer ratio; $\mathrm{NAA} / \mathrm{Cr}$ : $\mathrm{N}$-acetyl aspartate-creatine ratio; 
Table 4 (New): Summary of the strengths and weaknesses of the main outcome measures

\begin{tabular}{|c|c|c|}
\hline $\begin{array}{l}\text { Outcome measure } \\
\text { Used in clinical trials } \\
(T) \text {, in the clinic }(C) \text { or } \\
\text { in both }(B)\end{array}$ & $\begin{array}{l}\text { Strengths } \\
\text { In relation to their use in clinical } \\
\text { trials }(T) \text {, in the clinic }(C) \text { or in both } \\
\text { (B) }\end{array}$ & $\begin{array}{l}\text { Limitations } \\
\text { In relation to their use in clinical } \\
\text { trials }(T) \text {, in the clinic }(C) \text { or in } \\
\text { both }(B)\end{array}$ \\
\hline \multicolumn{3}{|c|}{ CLINICAL OUTCOME MEASURES } \\
\hline \multicolumn{3}{|c|}{ Relapse-centred outcome measures } \\
\hline $\begin{array}{l}\text { \# of relapses }(\mathrm{C}) \text { or ARR } \\
\text { (T) }\end{array}$ & Easy to compute and understand (B) & $\begin{array}{l}\text { Only relevant for relapsing forms } \\
\text { of MS (B) } \\
\text { No specific for MS severity (B) }\end{array}$ \\
\hline $\begin{array}{l}\text { \# of severe relapses }(\mathrm{C}) \\
\text { or ARSR }(\mathrm{T})\end{array}$ & $\begin{array}{l}\text { May reflect severity of MS relapses } \\
\text { (B) }\end{array}$ & $\begin{array}{l}\text { High inter-site variability due to } \\
\text { absence of guidelines for relapse } \\
\text { management }(T)\end{array}$ \\
\hline $\begin{array}{l}\% \text { of relapse-free } \\
\text { patients }(T)\end{array}$ & $\begin{array}{l}\text { In line with the concept of no } \\
\text { disease activity, useful for trials with } \\
\text { powerful drugs }(T)\end{array}$ & $\begin{array}{l}\text { Highly dependent on trial } \\
\text { duration, with statistical } \\
\text { implications (see main text for } \\
\text { more details) (T) }\end{array}$ \\
\hline $\begin{array}{l}\text { Time to confirmed } \\
\text { relapse }(T)\end{array}$ & Useful in CIS trials (T) & $\begin{array}{l}\text { Only relevant for relapsing forms } \\
\text { of MS (B) } \\
\text { No specific for MS severity (B) }\end{array}$ \\
\hline $\begin{array}{l}\text { Time to treatment } \\
\text { failure }(T)\end{array}$ & $\begin{array}{l}\text { Accounts for efficacy, safety and } \\
\text { tolerability of the drug (i.e. reflects } \\
\text { real-life scenario) (T) }\end{array}$ & Unspecific (T) \\
\hline \multicolumn{3}{|c|}{ Measures of disability progression } \\
\hline $\begin{array}{l}\text { Change in EDSS and } \\
\text { EDSS scores at follow- } \\
\text { up (B) }\end{array}$ & $\begin{array}{l}\text { Easy to understand by the MS } \\
\text { community }(B)\end{array}$ & $\begin{array}{l}\text { EDSS score changes do not } \\
\text { reflect what functional system } \\
\text { changes (B) } \\
\text { Sensitive to relapse-related } \\
\text { transient deficits (B) } \\
\text { EDSS is not sensitive to upper } \\
\text { limb or cognitive disability (B) } \\
\text { Low inter- and intra-rater } \\
\text { reproducibility (especially if low } \\
\text { EDSS scores) (B) }\end{array}$ \\
\hline $\begin{array}{l}\text { Change in MSFC or its } \\
\text { subscores and MSFC } \\
\text { scores at follow-up (B) }\end{array}$ & $\begin{array}{l}\text { No specific training required (B) } \\
\text { Sensitive to upper limb (NHPT) and } \\
\text { cognitive (PASAT) functions (B) } \\
\text { In the clinic, TWT is useful to } \\
\text { monitor drug effects, such as } \\
\text { fampridine (C) }\end{array}$ & $\begin{array}{l}\text { Designed to be used in trials, at } \\
\text { group level (i.e. reduced } \\
\text { usefulness in the clinic) (C) } \\
\text { Definition of clinically meaningful } \\
\text { change is required (mainly CT) } \\
\text { Choice of a reference population } \\
\text { affects z-scores (T) } \\
\text { Practice effects (B) } \\
\text { PASAT may be stressful (B) }\end{array}$ \\
\hline $\begin{array}{l}\text { Change in other clinical } \\
\text { (mainly cognitive) } \\
\text { scales (B) }\end{array}$ & $\begin{array}{l}\text { For SDMT, no specific training } \\
\text { required (B) } \\
\text { Sensitive to cognitive impairment (B) }\end{array}$ & $\begin{array}{l}\text { Training may be required for } \\
\text { cognitive tests (exc. SDMT) (B) } \\
\text { Reference population often } \\
\text { needed to interpret results (C) } \\
\text { Age, anxiety, fatigue and } \\
\text { education may influence results } \\
\text { (B) }\end{array}$ \\
\hline $\begin{array}{l}\% \text { of } 3 m / 6 m-C D P \text { in } \\
\text { EDSS }(T)\end{array}$ & $\begin{array}{l}\text { Easy to understand by the MS } \\
\text { community }(T)\end{array}$ & $\begin{array}{l}\text { Overestimation of long-term } \\
\text { disability accumulation }(T)\end{array}$ \\
\hline
\end{tabular}




\begin{tabular}{|c|c|c|}
\hline & & $\begin{array}{l}\text { Highly dependent on trial } \\
\text { duration, with statistical } \\
\text { implications }(T)\end{array}$ \\
\hline $\begin{array}{l}\text { \% free from } 3 \mathrm{~m} / 6 \mathrm{~m}- \\
\text { CDP in EDSS }(T)\end{array}$ & $\begin{array}{l}\text { Easy to understand by the MS } \\
\text { community }(T) \\
\text { In line with the concept of no } \\
\text { disease activity, useful for trials with } \\
\text { powerful drugs }(T)\end{array}$ & $\begin{array}{l}\text { Underestimation of \% patients } \\
\text { free from long-term disability } \\
\text { accumulation }(T) \\
\text { Highly dependent on trial } \\
\text { duration }(T)\end{array}$ \\
\hline $\begin{array}{l}\text { \% sustained } \\
\text { improvement in EDSS } \\
\text { (T) }\end{array}$ & $\begin{array}{l}\text { Useful to detect improvements of } \\
\text { disability, largely overlooked in MS } \\
\text { trials }(T)\end{array}$ & $\begin{array}{l}\text { May be unspecific in relation to } \\
\text { the pathophysiological process } \\
\text { underlying clinical improvement } \\
\text { (T) }\end{array}$ \\
\hline $\begin{array}{l}\% 3 m / 6 m-C D P \text { in MSFC } \\
\text { subscores }(T)\end{array}$ & $\begin{array}{l}\text { Strengths of the MSFC-related } \\
\text { outcome measures and outcome } \\
\text { measures that consider progression } \\
\text { as a binary phenomenon (see above) } \\
\text { (T) }\end{array}$ & $\begin{array}{l}\text { Limitations of the MSFC-related } \\
\text { outcome measures and outcome } \\
\text { measures that consider \% } \\
\text { patients with disability } \\
\text { progression (see above) }(\mathrm{T})\end{array}$ \\
\hline $\begin{array}{l}\text { Time to } 3 \mathrm{~m} / 6 \mathrm{~m}-\mathrm{CDP} \text { in } \\
\text { EDSS/MSFC and time } \\
\text { to a given EDSS/MSFC } \\
\text { score }(\mathrm{T})\end{array}$ & $\begin{array}{l}\text { Strengths of EDSS/MSFC-related } \\
\text { measures (T) } \\
\text { Informative about the effect of the } \\
\text { drug on immediate risk of CDP (as } \\
\text { opposed to '\% patients with CDP', } \\
\text { which considers the risk over a } \\
\text { relatively long period) (T) }\end{array}$ & $\begin{array}{l}\text { Limitations of EDSS/MSFC- } \\
\text { related measures }(T)\end{array}$ \\
\hline $\begin{array}{l}\text { Combined disability } \\
\text { outcomes (including } \\
\text { NECA) (B) }\end{array}$ & $\begin{array}{l}\text { Higher sensitivity than individual } \\
\text { components to detection of } \\
\text { disability progression, implying a } \\
\text { reduction in required sample } \\
\text { sizes/trial durations }(T) \\
\text { Reduction of the risk of type I error } \\
\text { (T) } \\
\text { NECA: comprehensive measure of } \\
\text { real-life treatment effect (B) }\end{array}$ & $\begin{array}{l}\text { Individual components cannot be } \\
\text { analysed independently, unless } \\
\text { they were pre-defined as } \\
\text { outcome measures }(\mathrm{T}) \\
\text { Composite outcomes must } \\
\text { include measures causally } \\
\text { related to treatment }(\mathrm{T})\end{array}$ \\
\hline \multicolumn{3}{|l|}{ PROMs } \\
\hline All PROMs (B) & $\begin{array}{l}\text { Information comes directly from the } \\
\text { patient (B) }\end{array}$ & $\begin{array}{l}\text { Information is subjective and } \\
\text { may fluctuate within subjects (B) }\end{array}$ \\
\hline \multicolumn{3}{|c|}{ NEUROIMAGING \& NEUROPHYSIOLOGICAL OUTCOME MEASURES } \\
\hline \multicolumn{3}{|c|}{ Outcome measures related to focal lesions } \\
\hline $\begin{array}{l}\text { T2-lesion-related } \\
\text { outcome measures (B) }\end{array}$ & $\begin{array}{l}\text { Information on new and cumulative } \\
\text { inflammatory activity (B) }\end{array}$ & $\begin{array}{l}\text { Temporal frameworks for new } \\
\text { inflammatory activity are } \\
\text { imprecise (B) }\end{array}$ \\
\hline $\begin{array}{l}\text { Gd-enhancing lesion- } \\
\text { related outcome } \\
\text { measures (B) }\end{array}$ & $\begin{array}{l}\text { Information on recent inflammatory } \\
\text { activity (within 3-6 weeks prior scan } \\
\text { date) (B) }\end{array}$ & $\begin{array}{l}\text { No information on cumulative } \\
\text { inflammatory activity (B) }\end{array}$ \\
\hline $\begin{array}{l}\text { Non-enhancing T1 } \\
\text { lesion-related outcome } \\
\text { measures (B) }\end{array}$ & $\begin{array}{l}\text { May inform about tissue destruction } \\
\text { secondary to inflammation and } \\
\text { repair (B) }\end{array}$ & $\begin{array}{l}\text { The delineation of hypointense } \\
\text { T1 lesions may depend on } \\
\text { scanner parameters (B) }\end{array}$ \\
\hline $\begin{array}{l}\text { Combined unique } \\
\text { active lesions (B) }\end{array}$ & $\begin{array}{l}\text { More sensitive than new T2 or } \\
\text { gadolinium-enhancing lesions } \\
\text { separately (B) }\end{array}$ & $\begin{array}{l}\text { Their computation is slightly } \\
\text { more complex than new T2 or } \\
\text { gadolinium-enhancing lesions (B) }\end{array}$ \\
\hline \multicolumn{3}{|c|}{ Non-lesion-related MRI outcome measures } \\
\hline $\begin{array}{l}\text { Brain atrophy-related } \\
\text { metrics (B) }\end{array}$ & $\begin{array}{l}\text { Reflect neurodegeneration, the } \\
\text { most important substrate of } \\
\text { disability accrual (B) }\end{array}$ & $\begin{array}{l}\text { Susceptible to pseudo-atrophy } \\
\text { phenomenon (B) }\end{array}$ \\
\hline
\end{tabular}




\begin{tabular}{|c|c|c|}
\hline & & $\begin{array}{l}\text { High intra-subject (physiological) } \\
\text { variation (B) }\end{array}$ \\
\hline $\begin{array}{l}\text { Spinal cord atrophy- } \\
\text { related metrics }(T)\end{array}$ & $\begin{array}{l}\text { Reflect neurodegeneration in the } \\
\text { spinal cord, highly related to motor } \\
\text { disability }(T)\end{array}$ & $\begin{array}{l}\text { Limited spatial resolution, which } \\
\text { hampers multi-centre studies }(T) \\
\text { Current segmentation methods } \\
\text { are semi-automated, implying } \\
\text { high inter-rater variability }(T)\end{array}$ \\
\hline $\begin{array}{l}\text { Novel imaging } \\
\text { outcomes (MTR, MR } \\
\text { spectroscopy, } \\
\text { diffusion-weighted, } \\
\text { PET-derived metrics) } \\
\text { (T) }\end{array}$ & $\begin{array}{l}\text { Information on microstructural } \\
\text { features of brain damage, } \\
\text { complementary to that given by } \\
\text { lesion-related or atrophy-related } \\
\text { measures }(T)\end{array}$ & $\begin{array}{l}\text { Standardisation of acquisition } \\
\text { protocols and analysis methods } \\
\text { still in progress }(\mathrm{T})\end{array}$ \\
\hline OCT (B) & $\begin{array}{l}\text { Information on axonal and neuronal } \\
\text { loss within the anterior visual } \\
\text { pathway (related to } \\
\text { neurodegeneration) (B) } \\
\text { Useful to monitor drugs' side effects } \\
\text { (fingolimod) (B) }\end{array}$ & $\begin{array}{l}\text { Less reliable if previous history of } \\
\text { optic neuritis (B) }\end{array}$ \\
\hline $\begin{array}{l}\text { Combined MRI and } \\
\text { clinical outcomes } \\
\text { (including NEDA) (B) }\end{array}$ & $\begin{array}{l}\text { NEDA: comprehensive measure of } \\
\text { real-life treatment effect }(B)\end{array}$ & $\begin{array}{l}\text { Difficult interpretation of the net } \\
\text { effect of drugs on the outcome } \\
\text { measure }(T) \\
\text { Reduced usefulness in the clinic } \\
\text { (high positive predictive value } \\
\text { but low negative predictive } \\
\text { value) (C) }\end{array}$ \\
\hline $\operatorname{VEPs}(T)$ & $\begin{array}{l}\text { May reflect remyelinating processes } \\
\text { secondary to experimental drugs }(T)\end{array}$ & $\begin{array}{l}\text { Not sensitive enough to monitor } \\
\text { disease progression (B) }\end{array}$ \\
\hline
\end{tabular}

Footnote table 4. Abbreviations: ARR: annualised relapse rate; $\mathrm{B}$ : both clinical trial and clinical setting; ARSR: annualised rate of severe relapses; $C$ : clinical setting; CDMS: clinically defined multiple sclerosis; CDP: confirmed disability progression; EDSS: expanded disability status scale; Gd: gadolinium; 9HPT: nine-hole peg test; MSFC: multiple sclerosis functional composite; MTR: magnetisation transfer ratio; NECA: No evidence of clinical activity; NEDA: No evidence of disease activity; PASAT: paced auditory serial addition test; OCT: optical coherence tomography; PET: positron emission tomography; PROMs: patient-reported outcome measures; SDMT: symbol digit modalities test; T: clinical trial; TWT: 25 -foot timed walk test; VEPs: visual evoked potentials. 


\section{Boxes}

\section{Box 1(New). Novel and future outcome measures}

Possible future clinical outcomes include those obtained through the utilisation of 'smart' technology such as wearable sensors have started to be developed for their use mainly in the clinic. Wearable sensors are electronic devices that can be attached to the body and record information about the user's quantity and quality of movement. This portable technology can provide objective and quantitative data ${ }^{184}$ which may be useful to detect response to therapeutic interventions in the real life. Besides, several strategies have been developed to maximise the sensitivity to disease progression of current disability scores. These include re-baselining the EDSS score according to both screening and first visits, and using new metrics such as the area under the curve described by the disability score trajectories over time ${ }^{131}$.

Possible future imaging outcomes include markers of remyelination, such as within-lesion $\mathrm{MTR}^{185}$ or the level of $\left[{ }^{11} \mathrm{C}\right] \mathrm{PIB}$ binding ${ }^{186}$, obtained with positron emission tomography (PET). Markers of chronic inflammation, such as the presence of slowly enlarging lesions ${ }^{187}$, and microglial activation, such as and level of TSPO binding ${ }^{188-190}$, also obtained through PET, can be used as future outcome measures too. These potential outcomes can bring us closer to achieving precision medicine ${ }^{189}$.

Advanced OCT techniques provide quantitative measurements of both retinal nerve fibre layer (RNFL, axonal) and ganglion cell layer (GCL, neuronal) loss in vivo, representing an ideal model for assessing the neuroprotective effects of novel agents ${ }^{118}$. Possible advantages of OCT in trials are that the evaluation of the retinal structure might predict the clinical response to treatment ${ }^{191}$ and the risk of developing specific ocular side effects ${ }^{192}$.

Finally, future neurophysiological outcomes would include visual evoked potentials and multimodal evoked potentials, which have shown some ability to predict clinical evolution in patients with $\mathrm{MS}^{193-195}$. Change in full-field VEPs latency at week-24 has been used as the primary outcome measure in a phase 2 trial assessing the efficacy of a remyelinating therapy after the first episode of optic neuritis ${ }^{196}$ 
Box 2. Main clinical and neuroimaging outcomes and derived outcome measures used in the clinical setting

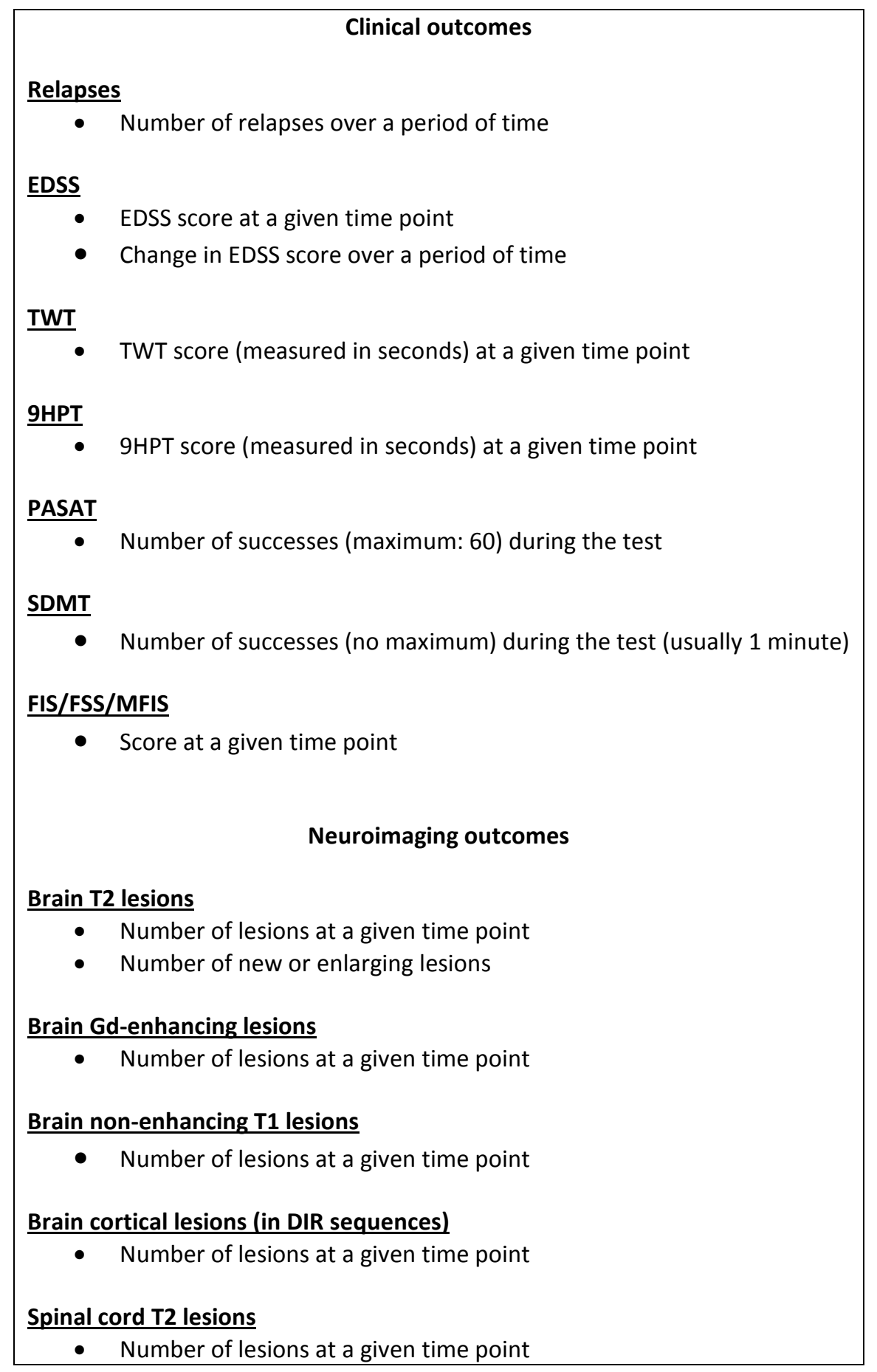

\section{Abbreviations:}

DIR: double inversion recovery; EDSS: Expanded Disability Status Scale; FIS (or UFIS): Unidimensional Fatigue Impact Scale; FSS: fatigue severity scale; 9HPT: Nine-Hole Peg Test; MFIS: modified fatigue impact scale; PASAT: Paced Auditory Serial Addition Test; SDMT: symbol digit modalities test; TWT: 25-Foot Timed Walk Test; 


\section{Figure legends}

Figure1: Number of phase III trials over time in relapsing and progressive MS

Figure 1 (legend).

This figure illustrates the increase in the number of phase III clinical trials carried out over the last five years, especially in relapsing MS patients. Abbreviations: CIS: clinically isolated syndrome; MS: multiple sclerosis; PPMS: primary progressive multiple sclerosis; SPMS: secondary progressive multiple ${ }^{1}$ sclerosis. 
Figure 2: Trends over time in phase III trials

2a: Evolution of number of trial endpoints over time;

$2 \mathrm{~b}$ : Evolution of number of participants per trial over time;

2c: Evolution of trial duration over time.

\section{Figure 2 (legend).}

This figure illustrates the evolution over time of (a) the number of trial endpoints per trial; (b) number of participants per trial; (c) trial duration. As can be observed, there has been a clear increase in the number of trial endpoints per trial and the number of participants per trial over the last 5-10 years, whereas the trial duration has remained very similar. Most of the trials have a duration of 2 or 3 years. Abbreviations: MS: multiple sclerosis; 


\section{$\underline{\text { References }}$}

1 Compston, A. \& Coles, A. Multiple sclerosis. Lancet 372, 1502-1517, doi:10.1016/S0140-6736(08)61620-7 (2008).

2 Trapp, B. D. \& Nave, K. A. Multiple sclerosis: an immune or neurodegenerative disorder? Annu Rev Neurosci 31, 247-269, doi:10.1146/annurev.neuro.30.051606.094313 (2008).

3 Alliance, P. M. < http://www.progressivemsalliance.org/> (

4 Bevan, C. J. \& Cree, B. A. Disease activity free status: a new end point for a new era in multiple sclerosis clinical research? JAMA Neurol 71, 269-270, doi:10.1001/jamaneurol.2013.5486 (2014).

5 Rio, J. et al. Defining the response to interferon-beta in relapsing-remitting multiple sclerosis patients. Ann Neurol 59, 344-352, doi:10.1002/ana.20740 (2006).

6 Rio, J., Comabella, M. \& Montalban, X. Predicting responders to therapies for multiple sclerosis. Nat Rev Neurol 5, 553-560, doi:10.1038/nrneurol.2009.139 (2009).

7 Hobart, J. C., Cano, S. J., Zajicek, J. P. \& Thompson, A. J. Rating scales as outcome measures for clinical trials in neurology: problems, solutions, and recommendations. Lancet Neurol 6, 1094-1105, doi:10.1016/S14744422(07)70290-9 (2007).

8 Coster, W. J. Making the best match: selecting outcome measures for clinical trials and outcome studies. Am J Occup Ther 67, 162-170, doi:10.5014/ajot.2013.006015 (2013).

9 US Department of Health and Human Services Food and Drug Administration, F. D. A. Guidance for industry: patient-reported outcome measures: use in medical product development to support labeling claims. http://www.fda.gov/downloads/Drugs/GuidanceComplianceRegulato rylnformation/Guidances/UCM193282.pdf. (2009).

10 Fox, R. J. et al. Setting a research agenda for progressive multiple sclerosis: the International Collaborative on Progressive MS. Mult Scler 18, 1534-1540, doi:10.1177/1352458512458169 (2012).

11 O'Connor, P. et al. 250 microg or 500 microg interferon beta-1b versus $20 \mathrm{mg}$ glatiramer acetate in relapsing-remitting multiple sclerosis: a prospective, randomised, multicentre study. Lancet Neuro/ 8, 889-897, doi:10.1016/S14744422(09)70226-1 (2009).

12 Uitdehaag, B. M. et al. The changing face of multiple sclerosis clinical trial populations. Curr Med Res Opin 27, 1529-1537, doi:10.1185/03007995.2011.591370 (2011).

13 Comi, G. et al. Placebo-controlled trial of oral laquinimod for multiple sclerosis. N Engl J Med 366, 1000-1009, doi:10.1056/NEJMoa1104318 (2012).

14 Kappos, L. et al. A placebo-controlled trial of oral fingolimod in relapsing multiple sclerosis. N Engl J Med 362, 387-401, doi:10.1056/NEJMoa0909494 (2010).

15 Vermersch, P. et al. Teriflunomide versus subcutaneous interferon beta-1a in patients with relapsing multiple sclerosis: a randomised, controlled phase 3 trial. Mult Scler 20, 705-716, doi:10.1177/1352458513507821 (2014). 
16 Calabresi, P. A. et al. Pegylated interferon beta-1a for relapsing-remitting multiple sclerosis (ADVANCE): a randomised, phase 3, double-blind study. Lancet Neurol 13, 657-665, doi:10.1016/S1474-4422(14)70068-7 (2014).

17 Randomised double-blind placebo-controlled study of interferon beta-1a in relapsing/remitting multiple sclerosis. PRISMS (Prevention of Relapses and Disability by Interferon beta-1a Subcutaneously in Multiple Sclerosis) Study Group. Lancet 352, 1498-1504 (1998).

18 Polman, C. H. et al. Diagnostic criteria for multiple sclerosis: 2005 revisions to the "McDonald Criteria". Ann Neurol 58, 840-846, doi:10.1002/ana.20703 (2005).

19 Polman, C. H. et al. Diagnostic criteria for multiple sclerosis: 2010 revisions to the McDonald criteria. Ann Neurol 69, 292-302, doi:10.1002/ana.22366 (2011).

20 McDonald, W. I. et al. Recommended diagnostic criteria for multiple sclerosis: guidelines from the International Panel on the diagnosis of multiple sclerosis. Ann Neurol 50, 121-127 (2001).

21 Kappos, L. et al. Treatment with interferon beta-1b delays conversion to clinically definite and McDonald MS in patients with clinically isolated syndromes. Neurology 67, 1242-1249, doi:10.1212/01.wnl.0000237641.33768.8d (2006).

22 Comi, G. et al. Comparison of two dosing frequencies of subcutaneous interferon beta-1a in patients with a first clinical demyelinating event suggestive of multiple sclerosis (REFLEX): a phase 3 randomised controlled trial. Lancet Neurol 11, 33-41, doi:10.1016/S1474-4422(11)70262-9 (2012).

23 Miller, A. E. et al. Oral teriflunomide for patients with a first clinical episode suggestive of multiple sclerosis (TOPIC): a randomised, double-blind, placebocontrolled, phase 3 trial. Lancet Neurol 13, 977-986, doi:10.1016/S14744422(14)70191-7 (2014).

Business

Wire,

B. W.

(http://www.businesswire.com/news/home/20151021005273/en/Biogen-

Reports-Top-Line-Results-Phase-3-Study, 2015).

25 Hawker, K. et al. Rituximab in patients with primary progressive multiple sclerosis: results of a randomized double-blind placebo-controlled multicenter trial. Ann Neurol 66, 460-471, doi:10.1002/ana.21867 (2009).

26 Montalban, X. et al. Ocrelizumab versus Placebo in Primary Progressive Multiple Sclerosis. N Engl J Med, doi:10.1056/NEJMoa1606468 (2016).

27 MS Society, M. <https://www.mssociety.org.uk/ms-research/treatments-inthe-pipeline/siponimod> (

28 Kurtzke, J. F. Rating neurologic impairment in multiple sclerosis: an expanded disability status scale (EDSS). Neurology 33, 1444-1452 (1983).

29 Cohen, J. A. et al. Alemtuzumab versus interferon beta 1a as first-line treatment for patients with relapsing-remitting multiple sclerosis: a randomised controlled phase 3 trial. Lancet 380, 1819-1828, doi:10.1016/S0140-6736(12)61769-3 (2012).

30 Coles, A. J. et al. Alemtuzumab for patients with relapsing multiple sclerosis after disease-modifying therapy: a randomised controlled phase 3 trial. Lancet 380, 1829-1839, doi:10.1016/S0140-6736(12)61768-1 (2012). 
31 Johnson, K. P. et al. Copolymer 1 reduces relapse rate and improves disability in relapsing-remitting multiple sclerosis: results of a phase III multicenter, double-blind placebo-controlled trial. The Copolymer 1 Multiple Sclerosis Study Group. Neurology 45, 1268-1276 (1995).

32 Lublin, F. D., Baier, M. \& Cutter, G. Effect of relapses on development of residual deficit in multiple sclerosis. Neurology 61, 1528-1532 (2003).

33 Ebers, G. C., Heigenhauser, L., Daumer, M., Lederer, C. \& Noseworthy, J. H. Disability as an outcome in MS clinical trials. Neurology 71, 624-631, doi:10.1212/01.wnl.0000313034.46883.16 (2008).

34 Noseworthy, J. H., Vandervoort, M. K., Wong, C. J. \& Ebers, G. C. Interrater variability with the Expanded Disability Status Scale (EDSS) and Functional Systems (FS) in a multiple sclerosis clinical trial. The Canadian Cooperation MS Study Group. Neurology 40, 971-975 (1990).

35 Mahoney, F. I. \& Barthel, D. W. Functional Evaluation: The Barthel Index. Md State Med J 14, 61-65 (1965).

36 Hobart, J. C. et al. Getting the measure of spasticity in multiple sclerosis: the Multiple Sclerosis Spasticity Scale (MSSS-88). Brain 129, 224-234, doi:10.1093/brain/awh675 (2006).

37 Hauser, S. L. et al. Intensive immunosuppression in progressive multiple sclerosis. A randomized, three-arm study of high-dose intravenous cyclophosphamide, plasma exchange, and ACTH. N Engl J Med 308, 173-180, doi:10.1056/NEJM198301273080401 (1983).

38 Goodkin, D. E., Hertsgaard, D. \& Seminary, J. Upper extremity function in multiple sclerosis: improving assessment sensitivity with box-and-block and nine-hole peg tests. Arch Phys Med Rehabil 69, 850-854 (1988).

39 Cutter, G. R. et al. Development of a multiple sclerosis functional composite as a clinical trial outcome measure. Brain 122 ( Pt 5), 871-882 (1999).

40 Lanzillo, R. et al. No evidence for an effect on brain atrophy rate of atorvastatin add-on to interferon beta1b therapy in relapsing-remitting multiple sclerosis (the ARIANNA study). Mult Scler 22, 1163-1173, doi:10.1177/1352458515611222 (2016).

41 Panitch, H., Miller, A., Paty, D., Weinshenker, B. \& North American Study Group on Interferon beta-1b in Secondary Progressive, M. S. Interferon beta-1b in secondary progressive MS: results from a 3-year controlled study. Neurology 63, 1788-1795 (2004).

42 Rao, S. \& Cognitive Function Group, N. A manual for the Brief Repeatable Battery of neuropsychological tests in multiple sclerosis. (National Multiple Sclerosis Society, New York, 1990).

43 Cohen, J. A. et al. Benefit of interferon beta-1a on MSFC progression in secondary progressive MS. Neurology 59, 679-687 (2002).

44 Freedman, M. S. et al. A phase III study evaluating the efficacy and safety of MBP8298 in secondary progressive MS. Neurology 77, 1551-1560, doi:10.1212/WNL.0b013e318233b240 (2011).

45 Kalincik, T. et al. Defining reliable disability outcomes in multiple sclerosis. Brain 138, 3287-3298, doi:10.1093/brain/awv258 (2015). 
46 Kragt, J. J. et al. Responsiveness and predictive value of EDSS and MSFC in primary progressive MS. Neurology 70, 1084-1091, doi:10.1212/01.wnl.0000288179.86056.e1 (2008).

47 Calabresi, P. A. et al. Safety and efficacy of fingolimod in patients with relapsing-remitting multiple sclerosis (FREEDOMS II): a double-blind, randomised, placebo-controlled, phase 3 trial. Lancet Neurol 13, 545-556, doi:10.1016/S1474-4422(14)70049-3 (2014).

48 Bosma, L. V. et al. Progression on the Multiple Sclerosis Functional Composite in multiple sclerosis: what is the optimal cut-off for the three components? Mult Scler 16, 862-867, doi:10.1177/1352458510370464 (2010).

49 Tourbah, A. et al. MD1003 (high-dose biotin) for the treatment of progressive multiple sclerosis: A randomised, double-blind, placebo-controlled study. Mult Scler 22, 1719-1731, doi:10.1177/1352458516667568 (2016).

50 Chataway, J. et al. Effect of high-dose simvastatin on brain atrophy and disability in secondary progressive multiple sclerosis (MS-STAT): a randomised, placebo-controlled, phase 2 trial. Lancet 383, 2213-2221, doi:10.1016/S01406736(13)62242-4 (2014).

51 ClinicalTrials.gov. US National Library of Medicine at the National Institutes of Health, <http://www.clinicaltrials.gov/ (access date: July 2017)> (

52 Zhang, J., Waubant, E., Cutter, G., Wolinsky, J. \& Leppert, D. Composite end points to assess delay of disability progression by MS treatments. Mult Scler 20, 1494-1501, doi:10.1177/1352458514527180 (2014).

53 Prieto-Merino, D., Smeeth, L., Staa, T. P. \& Roberts, I. Dangers of non-specific composite outcome measures in clinical trials. BMJ 347, f6782, doi:10.1136/bmj.f6782 (2013).

54 Lublin, F. et al. Oral fingolimod in primary progressive multiple sclerosis (INFORMS): a phase 3, randomised, double-blind, placebo-controlled trial. Lancet 387, 1075-1084, doi:10.1016/S0140-6736(15)01314-8 (2016).

55 Hommes, O. R. et al. Intravenous immunoglobulin in secondary progressive multiple sclerosis: randomised placebo-controlled trial. Lancet 364, 11491156, doi:10.1016/S0140-6736(04)17101-8 (2004).

56 Speight, J. \& Barendse, S. M. FDA guidance on patient reported outcomes. BMJ 340, c2921, doi:10.1136/bmj.c2921 (2010).

57 Hobart, J. \& Cano, S. Improving the evaluation of therapeutic interventions in multiple sclerosis: the role of new psychometric methods. Health Technol Assess 13, iii, ix-x, 1-177, doi:10.3310/hta13120 (2009).

58 Doward, L. C., McKenna, S. P., Meads, D. M., Twiss, J. \& Eckert, B. J. The development of patient-reported outcome indices for multiple sclerosis (PRIMUS). Mult Scler 15, 1092-1102, doi:10.1177/1352458509106513 (2009).

59 Vickrey, B. G., Hays, R. D., Harooni, R., Myers, L. W. \& Ellison, G. W. A healthrelated quality of life measure for multiple sclerosis. Qual Life Res 4, 187-206 (1995).

60 Krupp, L. B., LaRocca, N. G., Muir-Nash, J. \& Steinberg, A. D. The fatigue severity scale. Application to patients with multiple sclerosis and systemic lupus erythematosus. Arch Neurol 46, 1121-1123 (1989).

61 Frith, J. \& Newton, J. Fatigue Impact Scale. Occup Med (Lond) 60, 159, doi:10.1093/occmed/kqp180 (2010). 
62 Hobart, J. C., Riazi, A., Lamping, D. L., Fitzpatrick, R. \& Thompson, A. J. Measuring the impact of MS on walking ability: the 12-Item MS Walking Scale (MSWS-12). Neurology 60, 31-36 (2003).

63 Hobart, J., Cano, S., Ingram, W. \& Zajicek, J. A new path for the MS Walking Scale: MSWS-12 version 2. . Mult Scler. 18, 334-335 (2012).

64 Andersen, O. et al. Multicentre, randomised, double blind, placebo controlled, phase III study of weekly, low dose, subcutaneous interferon beta-1a in secondary progressive multiple sclerosis. I Neurol Neurosurg Psychiatry 75, 706-710 (2004).

65 Zajicek, J. et al. Effect of dronabinol on progression in progressive multiple sclerosis (CUPID): a randomised, placebo-controlled trial. Lancet Neurol 12, 857-865, doi:10.1016/S1474-4422(13)70159-5 (2013).

66 Hobart, J. Prolonged-release fampridine for multiple sclerosis: was the effect on walking ability clinically significant? . Mult Scler 16(Suppl 10):S172. (2010).

67 Goodman, A. D. et al. Sustained-release oral fampridine in multiple sclerosis: a randomised, double-blind, controlled trial. Lancet 373, 732-738, doi:10.1016/S0140-6736(09)60442-6 (2009).

68 Novotna, A. et al. A randomized, double-blind, placebo-controlled, parallelgroup, enriched-design study of nabiximols* (Sativex((R)) ), as add-on therapy, in subjects with refractory spasticity caused by multiple sclerosis. Eur J Neurol 18, 1122-1131, doi:10.1111/j.1468-1331.2010.03328.x (2011).

69 Zajicek, J. et al. Cannabinoids for treatment of spasticity and other symptoms related to multiple sclerosis (CAMS study): multicentre randomised placebocontrolled trial. Lancet 362, 1517-1526, doi:10.1016/S0140-6736(03)14738-1 (2003).

70 Learmonth, Y. C., Motl, R. W., Sandroff, B. M., Pula, J. H. \& Cadavid, D. Validation of patient determined disease steps (PDDS) scale scores in persons with multiple sclerosis. BMC Neurol 13, 37, doi:10.1186/1471-2377-13-37 (2013).

71 Barkhof, F. et al. MRI monitoring of immunomodulation in relapse-onset multiple sclerosis trials. Nat Rev Neurol 8, 13-21, doi:10.1038/nrneurol.2011.190 (2011).

72 Cotton, F., Weiner, H. L., Jolesz, F. A. \& Guttmann, C. R. MRI contrast uptake in new lesions in relapsing-remitting MS followed at weekly intervals. Neurology 60, 640-646 (2003).

73 Filippi, M., Preziosa, P. \& Rocca, M. A. Magnetic resonance outcome measures in multiple sclerosis trials: time to rethink? Curr Opin Neurol 27, 290-299, doi:10.1097/WCO.0000000000000095 (2014).

74 Mitjana, R. et al. Diagnostic value of brain chronic black holes on T1-weighted MR images in clinically isolated syndromes. Mult Scler 20, 1471-1477, doi:10.1177/1352458514526083 (2014).

75 Comi, G. et al. Effect of early interferon treatment on conversion to definite multiple sclerosis: a randomised study. Lancet 357, 1576-1582 (2001).

76 Secondary Progressive Efficacy Clinical Trial of Recombinant Interferon-Beta$1 \mathrm{a}$ in, M. S. S. G. Randomized controlled trial of interferon- beta-1a in secondary progressive MS: Clinical results. Neurology 56, 1496-1504 (2001). 
77 Li, D. K., Zhao, G. J., Paty, D. W. \& University of British Columbia, M. S. M. R. I. A. R. G. T. S. S. G. Randomized controlled trial of interferon-beta-1a in secondary progressive MS: MRI results. Neurology 56, 1505-1513 (2001).

78 Tintore, M. et al. Defining high, medium and low impact prognostic factors for developing multiple sclerosis. Brain 138, 1863-1874, doi:10.1093/brain/awv105 (2015).

79 Sormani, M. P. et al. Magnetic resonance imaging as a potential surrogate for relapses in multiple sclerosis: a meta-analytic approach. Ann Neurol 65, 268275, doi:10.1002/ana.21606 (2009).

80 Sormani, M. P. \& Bruzzi, P. MRI lesions as a surrogate for relapses in multiple sclerosis: a meta-analysis of randomised trials. Lancet Neurol 12, 669-676, doi:10.1016/S1474-4422(13)70103-0 (2013).

81 Cohen, J. et al. Equivalence of Generic Glatiramer Acetate in Multiple Sclerosis: A Randomized Clinical Trial. JAMA Neurol 72, 1433-1441, doi:10.1001/jamaneurol.2015.2154 (2015).

82 Moraal, B. et al. Long-interval T2-weighted subtraction magnetic resonance imaging: a powerful new outcome measure in multiple sclerosis trials. Ann Neurol 67, 667-675, doi:10.1002/ana.21958 (2010).

83 Tedeschi, E. et al. In vivo dentate nucleus MRI relaxometry correlates with previous administration of Gadolinium-based contrast agents. Eur Radiol 26, 4577-4584, doi:10.1007/s00330-016-4245-2 (2016).

84 Fisniku, L. K. et al. Gray matter atrophy is related to long-term disability in multiple sclerosis. Ann Neurol 64, 247-254, doi:10.1002/ana.21423 (2008).

85 Miller, D. H., Barkhof, F., Frank, J. A., Parker, G. J. \& Thompson, A. J. Measurement of atrophy in multiple sclerosis: pathological basis, methodological aspects and clinical relevance. Brain 125, 1676-1695 (2002).

86 Sormani, M. P., Arnold, D. L. \& De Stefano, N. Treatment effect on brain atrophy correlates with treatment effect on disability in multiple sclerosis. Ann Neurol 75, 43-49, doi:10.1002/ana.24018 (2014).

87 Barkhof, F., Giovannoni, G., Hartung, H.-P., Cree, B., Uccelli, A., Sormani, M.P., Krieger, S., Uitdehaag, B., Vollmer, T., Montalban, X., Steinerman, J., Sasson, N., Gorfine, T. and Knappertz, V. ARPEGGIO: A randomized, placebo-controlled study to evaluate oral laquinimod in patients with primary progressive multiple sclerosis (PPMS). Neurology 84 (2015).

88 Comi, G. et al. Effect of glatiramer acetate on conversion to clinically definite multiple sclerosis in patients with clinically isolated syndrome (PreCISe study): a randomised, double-blind, placebo-controlled trial. Lancet 374, 1503-1511, doi:10.1016/S0140-6736(09)61259-9 (2009).

89 Kapoor, R. et al. Lamotrigine for neuroprotection in secondary progressive multiple sclerosis: a randomised, double-blind, placebo-controlled, parallelgroup trial. Lancet Neurol 9, 681-688, doi:10.1016/S1474-4422(10)70131-9 (2010).

90 Rudick, R. A., Fisher, E., Lee, J. C., Simon, J. \& Jacobs, L. Use of the brain parenchymal fraction to measure whole brain atrophy in relapsing-remitting MS. Multiple Sclerosis Collaborative Research Group. Neurology 53, 1698-1704 (1999). 
91 Smith, S. M., De Stefano, N., Jenkinson, M. \& Matthews, P. M. Normalized accurate measurement of longitudinal brain change. J Comput Assist Tomogr 25, 466-475 (2001).

92 Smith, S. M. et al. Accurate, robust, and automated longitudinal and crosssectional brain change analysis. Neuroimage 17, 479-489 (2002).

93 Miller, D. H. et al. MRI outcomes in a placebo-controlled trial of natalizumab in relapsing MS. Neurology 68, 1390-1401, doi:10.1212/01.wnl.0000260064.77700.fd (2007).

94 Montalban, X. et al. A single-center, randomized, double-blind, placebocontrolled study of interferon beta-1b on primary progressive and transitional multiple sclerosis. Mult Scler 15, 1195-1205, doi:10.1177/1352458509106937 (2009).

95 Cohen, J. A. et al. Oral fingolimod or intramuscular interferon for relapsing multiple sclerosis. N Engl J Med 362, 402-415, doi:10.1056/NEJMoa0907839 (2010).

96 Vollmer, T. L. et al. A randomized placebo-controlled phase III trial of oral laquinimod for multiple sclerosis. J Neurol 261, 773-783, doi:10.1007/s00415014-7264-4 (2014).

97 Vidal-Jordana, A. et al. Brain Volume Loss During the First Year of InterferonBeta Treatment in Multiple Sclerosis: Baseline Inflammation and Regional Brain Volume Dynamics. J Neuroimaging 26, 532-538, doi:10.1111/jon.12337 (2016).

98 Molyneux, P. D. et al. The effect of interferon beta-1b treatment on MRI measures of cerebral atrophy in secondary progressive multiple sclerosis. European Study Group on Interferon beta-1b in secondary progressive multiple sclerosis. Brain 123 ( Pt 11), 2256-2263 (2000).

99 Nakamura, K. et al. Diurnal fluctuations in brain volume: Statistical analyses of MRI from large populations. Neuroimage 118, 126-132, doi:10.1016/j.neuroimage.2015.05.077 (2015).

100 Nunes, P. V. et al. Factors associated with brain volume in major depression in older adults without dementia: results from a large autopsy study. Int J Geriatr Psychiatry, doi:10.1002/gps.4649 (2017).

101 Lublin, F. D. et al. Randomized study combining interferon and glatiramer acetate in multiple sclerosis. Ann Neurol 73, 327-340, doi:10.1002/ana.23863 (2013).

102 O'Connor, P. et al. Randomized trial of oral teriflunomide for relapsing multiple sclerosis. N Engl J Med 365, 1293-1303, doi:10.1056/NEJMoa1014656 (2011).

103 Vidal-Jordana, A. et al. Early brain pseudoatrophy while on natalizumab therapy is due to white matter volume changes. Mult Scler 19, 1175-1181, doi:10.1177/1352458512473190 (2013).

104 Vidal-Jordana, A., Sastre-Garriga, J., Rovira, A. \& Montalban, X. Treating relapsing-remitting multiple sclerosis: therapy effects on brain atrophy. $J$ Neurol 262, 2617-2626, doi:10.1007/s00415-015-7798-0 (2015).

105 Fisher, E., Lee, J. C., Nakamura, K. \& Rudick, R. A. Gray matter atrophy in multiple sclerosis: a longitudinal study. Ann Neurol 64, 255-265, doi:10.1002/ana.21436 (2008). 
106 Brownlee, W. J. et al. Association of asymptomatic spinal cord lesions and atrophy with disability 5 years after a clinically isolated syndrome. Mult Scler, doi:10.1177/1352458516663034 (2016).

107 Lin, X., Tench, C. R., Turner, B., Blumhardt, L. D. \& Constantinescu, C. S. Spinal cord atrophy and disability in multiple sclerosis over four years: application of a reproducible automated technique in monitoring disease progression in a cohort of the interferon beta-1a (Rebif) treatment trial. J Neurol Neurosurg Psychiatry 74, 1090-1094 (2003).

108 De Stefano, N. et al. Assessing brain atrophy rates in a large population of untreated multiple sclerosis subtypes. Neurology 74, 1868-1876, doi:10.1212/WNL.0b013e3181e24136 (2010).

109 Lukas, C. et al. Cervical spinal cord volume loss is related to clinical disability progression in multiple sclerosis. J Neurol Neurosurg Psychiatry 86, 410-418, doi:10.1136/jnnp-2014-308021 (2015).

110 Cawley, N., Tur, C. ; Prados, F.; Plantone, D.; Kearney, H.; Abdel - Aziz, K.; Ourselin, S.; Gandini Wheeler - Kingshott, C.A.M.; Miller, D.H.; Thompson, A.J.; Ciccarelli, O. Spinal cord atrophy as a primary outcome measure in phase II trials of progressive multiple sclerosis. Mult Scler Journal (under review) (2016).

111 Gold, R. et al. Placebo-controlled phase 3 study of oral BG-12 for relapsing multiple sclerosis. N Eng/ J Med 367, 1098-1107, doi:10.1056/NEJMoa1114287 (2012).

112 Schmierer, K., Scaravilli, F., Altmann, D. R., Barker, G. J. \& Miller, D. H. Magnetization transfer ratio and myelin in postmortem multiple sclerosis brain. Ann Neurol 56, 407-415, doi:10.1002/ana.20202 (2004).

113 Arnold, D. L. et al. Magnetization transfer ratio in the delayed-release dimethyl fumarate DEFINE study. I Neurol 261, 2429-2437, doi:10.1007/s00415-0147504-7 (2014).

114 Narayanan, S. et al. Axonal metabolic recovery in multiple sclerosis patients treated with interferon beta-1b. J Neurol 248, 979-986 (2001).

115 Zhang, H., Schneider, T., Wheeler-Kingshott, C. A. \& Alexander, D. C. NODDI: practical in vivo neurite orientation dispersion and density imaging of the human brain. Neuroimage 61, 1000-1016, doi:10.1016/j.neuroimage.2012.03.072 (2012).

116 Paling, D. et al. Sodium accumulation is associated with disability and a progressive course in multiple sclerosis. Brain 136, 2305-2317, doi:10.1093/brain/awt149 (2013).

117 Sergott, R. C. et al. ATON: results from a Phase II randomized trial of the B-celltargeting agent atacicept in patients with optic neuritis. J Neurol Sci 351, 174178, doi:10.1016/j.jns.2015.02.019 (2015).

118 Balcer, L. J. Clinical trials to clinical use: using vision as a model for multiple sclerosis and beyond. J Neuroophthalmol 34 Suppl, S18-23, doi:10.1097/WNO.0000000000000163 (2014).

119 Saidha, S. et al. Optical coherence tomography reflects brain atrophy in multiple sclerosis: A four-year study. Ann Neurol 78, 801-813, doi:10.1002/ana.24487 (2015). 
120 Raftopoulos, R. et al. Phenytoin for neuroprotection in patients with acute optic neuritis: a randomised, placebo-controlled, phase 2 trial. Lancet Neurol 15, 259-269, doi:10.1016/S1474-4422(16)00004-1 (2016).

121 Cambron, M. et al. Fluoxetine in progressive multiple sclerosis (FLUOX-PMS): study protocol for a randomized controlled trial. Trials 15, 37, doi:10.1186/1745-6215-15-37 (2014).

122 Rice, C. M. et al. Assessment of bone marrow-derived Cellular Therapy in progressive Multiple Sclerosis (ACTiMuS): study protocol for a randomised controlled trial. Trials 16, 463, doi:10.1186/s13063-015-0953-1 (2015).

123 Polman, C. H. et al. A randomized, placebo-controlled trial of natalizumab for relapsing multiple sclerosis. N Engl J Med 354, 899-910, doi:10.1056/NEJMoa044397 (2006).

124 Burman, J. et al. Autologous haematopoietic stem cell transplantation for aggressive multiple sclerosis: the Swedish experience. J Neurol Neurosurg Psychiatry 85, 1116-1121, doi:10.1136/jnnp-2013-307207 (2014).

125 Atkins, H. L. et al. Immunoablation and autologous haemopoietic stem-cell transplantation for aggressive multiple sclerosis: a multicentre single-group phase 2 trial. Lancet 388, 576-585, doi:10.1016/S0140-6736(16)30169-6 (2016).

126 Sormani, M. P., Muraro, P. A., Saccardi, R. \& Mancardi, G. NEDA status in highly active MS can be more easily obtained with autologous hematopoietic stem cell transplantation than other drugs. Mult Scler, doi:10.1177/1352458516645670 (2016).

127 Kappos, L. et al. Inclusion of brain volume loss in a revised measure of 'no evidence of disease activity' (NEDA-4) in relapsing-remitting multiple sclerosis. Mult Scler 22, 1297-1305, doi:10.1177/1352458515616701 (2016).

128 Nash, R. A. et al. High-dose immunosuppressive therapy and autologous hematopoietic cell transplantation for relapsing-remitting multiple sclerosis (HALT-MS): a 3-year interim report. JAMA Neurol 72, 159-169, doi:10.1001/jamaneurol.2014.3780 (2015).

129 Assessment., E. N. f. H. T. Endpoints used for REA of pharmaceuticals: composite endpoints, <http://www.eunethta.eu/outputs/methodologicalguideline-rea-pharmaceuticals-composite-endpoints> (2013).

130 Kalincik, T. et al. Treatment effectiveness of alemtuzumab compared with natalizumab, fingolimod, and interferon beta in relapsing-remitting multiple sclerosis: a cohort study. Lancet Neurol 16, 271-281, doi:10.1016/S14744422(17)30007-8 (2017).

131 Lorscheider, J. et al. Anti-inflammatory disease-modifying treatment and short-term disability progression in SPMS. Neurology, doi:10.1212/WNL.0000000000004330 (2017).

132 Sormani, M. P. et al. Combined MRI lesions and relapses as a surrogate for disability in multiple sclerosis. Neurology 77, 1684-1690, doi:10.1212/WNL.0b013e31823648b9 (2011).

133 Sormani, M. P. et al. Assessing response to interferon-beta in a multicenter dataset of patients with MS. Neurology 87, 134-140, doi:10.1212/WNL.0000000000002830 (2016). 
134 Rudick, R. et al. Clinical outcomes assessment in multiple sclerosis. Ann Neurol 40, 469-479, doi:10.1002/ana.410400321 (1996).

135 Gronwall, D. M. Paced auditory serial-addition task: a measure of recovery from concussion. Percept Mot Skills 44, 367-373, doi:10.2466/pms.1977.44.2.367 (1977).

136 Fragoso, Y. D. et al. Real-life experience with fampridine (Fampyra(R)) for patients with multiple sclerosis and gait disorders. NeuroRehabilitation 39, 301-304, doi:10.3233/NRE-161361 (2016).

137 Barker-Collo, S. L. Within session practice effects on the PASAT in clients with multiple sclerosis. Arch Clin Neuropsychol 20, 145-152, doi:10.1016/j.acn.2004.03.007 (2005).

138 Solari, A., Radice, D., Manneschi, L., Motti, L. \& Montanari, E. The multiple sclerosis functional composite: different practice effects in the three test components. J Neurol Sci 228, 71-74, doi:10.1016/j.jns.2004.09.033 (2005).

139 Brooks, J. B. et al. Paced auditory serial addition test (PASAT): a very difficult test even for individuals with high intellectual capability. Arq Neuropsiquiatr 69, 482-484 (2011).

140 Langdon, D. W. et al. Recommendations for a Brief International Cognitive Assessment for Multiple Sclerosis (BICAMS). Mult Scler 18, 891-898, doi:10.1177/1352458511431076 (2012).

141 Smith, A. Symbol digit modalities test. . (Western Psychological Services, 1991).

142 Amato, M. P. et al. The Rao's Brief Repeatable Battery and Stroop Test: normative values with age, education and gender corrections in an Italian population. Mult Scler 12, 787-793 (2006).

143 Tur, C. et al. Grey matter damage and overall cognitive impairment in primary progressive multiple sclerosis. Mult Scler 17, 1324-1332, doi:10.1177/1352458511410341 (2011).

144 Sonder, J. M., Burggraaff, J., Knol, D. L., Polman, C. H. \& Uitdehaag, B. M. Comparing long-term results of PASAT and SDMT scores in relation to neuropsychological testing in multiple sclerosis. Mult Scler 20, 481-488, doi:10.1177/1352458513501570 (2014).

145 Jacques, F. H. et al. Cognitive evolution in natalizumab-treated multiple sclerosis patients. Mult Scler J Exp Transl Clin 2, 2055217316657116, doi:10.1177/2055217316657116 (2016).

146 Fisk, J. D., Pontefract, A., Ritvo, P. G., Archibald, C. J. \& Murray, T. J. The impact of fatigue on patients with multiple sclerosis. Can J Neurol Sci 21, 9-14 (1994).

147 Kos, D., Nagels, G., D'Hooghe, M. B., Duportail, M. \& Kerckhofs, E. A rapid screening tool for fatigue impact in multiple sclerosis. BMC Neurol 6, 27, doi:10.1186/1471-2377-6-27 (2006).

148 Wattjes, M. P. et al. Evidence-based guidelines: MAGNIMS consensus guidelines on the use of $\mathrm{MRI}$ in multiple sclerosis--establishing disease prognosis and monitoring patients. Nat Rev Neurol 11, 597-606, doi:10.1038/nrneurol.2015.157 (2015).

149 Traboulsee, A. et al. Revised Recommendations of the Consortium of MS Centers Task Force for a Standardized MRI Protocol and Clinical Guidelines for 
the Diagnosis and Follow-Up of Multiple Sclerosis. AJNR Am J Neuroradiol 37, 394-401, doi:10.3174/ajnr.A4539 (2016).

150 Scolding, N. et al. Association of British Neurologists: revised (2015) guidelines for prescribing disease-modifying treatments in multiple sclerosis. Pract Neurol 15, 273-279, doi:10.1136/practneurol-2015-001139 (2015).

151 Rovira, A. et al. Evidence-based guidelines: MAGNIMS consensus guidelines on the use of MRI in multiple sclerosis-clinical implementation in the diagnostic process. Nat Rev Neurol 11, 471-482, doi:10.1038/nrneurol.2015.106 (2015).

152 Pareto, D. et al. Lesion filling effect in regional brain volume estimations: a study in multiple sclerosis patients with low lesion load. Neuroradiology 58, 467-474, doi:10.1007/s00234-016-1654-5 (2016).

153 Kanda, T. et al. Gadolinium deposition in the brain. Magn Reson Imaging, doi:10.1016/j.mri.2016.08.024 (2016).

154 Gulani, V. et al. Gadolinium deposition in the brain: summary of evidence and recommendations. Lancet Neurol 16, 564-570, doi:10.1016/S14744422(17)30158-8 (2017).

155 McGuigan, C. et al. Stratification and monitoring of natalizumab-associated progressive multifocal leukoencephalopathy risk: recommendations from an expert group. J Neurol Neurosurg Psychiatry 87, 117-125, doi:10.1136/jnnp2015-311100 (2016).

156 Chard, D. Brain atrophy measurements should be used to guide therapy monitoring in MS - Commentary. Mult Scler 22, 1526-1527, doi:10.1177/1352458516656061 (2016).

157 Barkhof, F. Brain atrophy measurements should be used to guide therapy monitoring in MS - NO. Mult Scler 22, 1524-1526, doi:10.1177/1352458516649452 (2016).

158 Zivadinov, R., Dwyer, M. G. \& Bergsland, N. Brain atrophy measurements should be used to guide therapy monitoring in MS - YES. Mult Scler 22, 15221524, doi:10.1177/1352458516649253 (2016).

159 Smeets, D. et al. Reliable measurements of brain atrophy in individual patients with multiple sclerosis. Brain Behav 6, e00518, doi:10.1002/brb3.518 (2016).

160 Dwyer, M. G. et al. Neurological software tool for reliable atrophy measurement (NeuroSTREAM) of the lateral ventricles on clinical-quality T2FLAIR MRI scans in multiple sclerosis. Neuroimage Clin 15, 769-779, doi:10.1016/j.nicl.2017.06.022 (2017).

161 Vrenken, H. et al. Recommendations to improve imaging and analysis of brain lesion load and atrophy in longitudinal studies of multiple sclerosis. $J$ Neurol 260, 2458-2471, doi:10.1007/s00415-012-6762-5 (2013).

162 University of California, S. F. M. S. E. T. et al. Long-term evolution of multiple sclerosis disability in the treatment era. Ann Neurol 80, 499-510, doi:10.1002/ana.24747 (2016).

163 Rothwell, P. M., McDowell, Z., Wong, C. K. \& Dorman, P. J. Doctors and patients don't agree: cross sectional study of patients' and doctors' perceptions and assessments of disability in multiple sclerosis. BMJ 314, 1580-1583 (1997).

164 Jacobs, L. D. et al. Intramuscular interferon beta-1a therapy initiated during a first demyelinating event in multiple sclerosis. CHAMPS Study Group. N Engl J Med 343, 898-904, doi:10.1056/NEJM200009283431301 (2000). 
165 Leist, T. P. et al. Effect of oral cladribine on time to conversion to clinically definite multiple sclerosis in patients with a first demyelinating event (ORACLE MS): a phase 3 randomised trial. Lancet Neurol 13, 257-267, doi:10.1016/S1474-4422(14)70005-5 (2014).

166 Giovannoni, G. et al. A placebo-controlled trial of oral cladribine for relapsing multiple sclerosis. N Engl J Med 362, 416-426, doi:10.1056/NEJMoa0902533 (2010).

167 Miller, D. H. et al. Effects of delayed-release dimethyl fumarate on MRI measures in the phase 3 CONFIRM study. Neurology 84, 1145-1152, doi:10.1212/WNL.0000000000001360 (2015).

168 Massacesi, L. et al. Azathioprine versus beta interferons for relapsing-remitting multiple sclerosis: a multicentre randomized non-inferiority trial. PLoS One 9, e113371, doi:10.1371/journal.pone.0113371 (2014).

169 Placebo-controlled multicentre randomised trial of interferon beta- $1 \mathrm{~b}$ in treatment of secondary progressive multiple sclerosis. European Study Group on interferon beta-1b in secondary progressive MS. Lancet 352, 1491-1497 (1998).

170 Panitch, $\mathrm{H}$. et al. Randomized, comparative study of interferon beta-1a treatment regimens in MS: The EVIDENCE Trial. Neurology 59, 1496-1506 (2002).

171 Khan, O. et al. Three times weekly glatiramer acetate in relapsing-remitting multiple sclerosis. Ann Neurol 73, 705-713, doi:10.1002/ana.23938 (2013).

172 Mikol, D. D. et al. Comparison of subcutaneous interferon beta-1a with glatiramer acetate in patients with relapsing multiple sclerosis (the REbif vs Glatiramer Acetate in Relapsing MS Disease [REGARD] study): a multicentre, randomised, parallel, open-label trial. Lancet Neurol 7, 903-914, doi:10.1016/S1474-4422(08)70200-X (2008).

173 Sorensen, P. S. et al. Simvastatin as add-on therapy to interferon beta-1a for relapsing-remitting multiple sclerosis (SIMCOMBIN study): a placebocontrolled randomised phase 4 trial. Lancet Neurol 10, 691-701, doi:10.1016/S1474-4422(11)70144-2 (2011).

174 Kappos, L. et al. Daclizumab HYP versus Interferon Beta-1a in Relapsing Multiple Sclerosis. N Engl J Med 373, 1418-1428, doi:10.1056/NEJMoa1501481 (2015).

175 Comi, G., Filippi, M. \& Wolinsky, J. S. European/Canadian multicenter, doubleblind, randomized, placebo-controlled study of the effects of glatiramer acetate on magnetic resonance imaging--measured disease activity and burden in patients with relapsing multiple sclerosis. European/Canadian Glatiramer Acetate Study Group. Ann Neurol 49, 290-297 (2001).

176 Comi, G. et al. Phase III dose-comparison study of glatiramer acetate for multiple sclerosis. Ann Neurol 69, 75-82, doi:10.1002/ana.22316 (2011).

177 Noseworthy, J. H. et al. Linomide in relapsing and secondary progressive MS: part I: trial design and clinical results. North American Linomide Investigators. Neurology 54, 1726-1733 (2000).

178 Jacobs, L. D. et al. Intramuscular interferon beta-1a for disease progression in relapsing multiple sclerosis. The Multiple Sclerosis Collaborative Research Group (MSCRG). Ann Neurol 39, 285-294, doi:10.1002/ana.410390304 (1996). 
179 Rudick, R. A. et al. Natalizumab plus interferon beta-1a for relapsing multiple sclerosis. N Engl J Med 354, 911-923, doi:10.1056/NEJMoa044396 (2006).

180 Interferon beta-1b is effective in relapsing-remitting multiple sclerosis. I. Clinical results of a multicenter, randomized, double-blind, placebo-controlled trial. The IFNB Multiple Sclerosis Study Group. Neurology 43, 655-661 (1993).

181 Confavreux, C. et al. Oral teriflunomide for patients with relapsing multiple sclerosis (TOWER): a randomised, double-blind, placebo-controlled, phase 3 trial. Lancet Neurol 13, 247-256, doi:10.1016/S1474-4422(13)70308-9 (2014).

182 Wolinsky, J. S. et al. Glatiramer acetate in primary progressive multiple sclerosis: results of a multinational, multicenter, double-blind, placebocontrolled trial. Ann Neurol 61, 14-24, doi:10.1002/ana.21079 (2007).

183 Wolinsky, J. S. et al. Linomide in relapsing and secondary progressive MS: part II: MRI results. MRI Analysis Center of the University of Texas-Houston, Health Science Center, and the North American Linomide Investigators. Neurology 54, 1734-1741 (2000).

184 Balto, J. M., Kinnett-Hopkins, D. L. \& Motl, R. W. Accuracy and precision of smartphone applications and commercially available motion sensors in multiple sclerosis. Multiple Sclerosis Journal - Experimental, Translational and Clinical, doi:DOI: 10.1177/ 2055217316634754 (2016).

185 Schwartzbach, C. J. et al. Lesion remyelinating activity of GSK239512 versus placebo in patients with relapsing-remitting multiple sclerosis: a randomised, single-blind, phase II study. J Neurol 264, 304-315, doi:10.1007/s00415-0168341-7 (2017).

186 Bodini, B. et al. Dynamic imaging of individual remyelination profiles in multiple sclerosis. Ann Neurol, doi:10.1002/ana.24620 (2016).

187 Sethi, V. et al. Slowly eroding lesions in multiple sclerosis. Mult Scler 23, 464472, doi:10.1177/1352458516655403 (2017).

188 Ching, A. S. et al. Current paradigm of the 18-kDa translocator protein (TSPO) as a molecular target for PET imaging in neuroinflammation and neurodegenerative diseases. Insights Imaging 3, 111-119, doi:10.1007/s13244-011-0128-x (2012).

189 Poutiainen, P., Jaronen, M., Quintana, F. J. \& Brownell, A. L. Precision Medicine in Multiple Sclerosis: Future of PET Imaging of Inflammation and Reactive Astrocytes. Front Mol Neurosci 9, 85, doi:10.3389/fnmol.2016.00085 (2016).

190 Herranz, E. et al. Neuroinflammatory component of gray matter pathology in multiple sclerosis. Ann Neurol 80, 776-790, doi:10.1002/ana.24791 (2016).

191 Horton, L. et al. Effect of 4-aminopyridine on vision in multiple sclerosis patients with optic neuropathy. Neurology 80, 1862-1866, doi:10.1212/WNL.0b013e3182929fd5 (2013).

192 Zarbin, M. A. et al. Ophthalmic evaluations in clinical studies of fingolimod (FTY720) in multiple sclerosis. Ophthalmology 120, 1432-1439, doi:10.1016/j.ophtha.2012.12.040 (2013).

193 Fuhr, P., Borggrefe-Chappuis, A., Schindler, C. \& Kappos, L. Visual and motor evoked potentials in the course of multiple sclerosis. Brain 124, 2162-2168 (2001). 
194 Jung, P., Beyerle, A. \& Ziemann, U. Multimodal evoked potentials measure and predict disability progression in early relapsing-remitting multiple sclerosis. Mult Scler 14, 553-556, doi:10.1177/1352458507085758 (2008).

195 Pelayo, R. et al. Do multimodal evoked potentials add information to MRI in clinically isolated syndromes? Mult Scler 16, 55-61, doi:10.1177/1352458509352666 (2010).

196 Cadavid, D., Balcer, L., Galetta, S., Aktas, O., Ziemssen, T., Vanopdenbosch, L., Butzkueven, H., Ziemssen, F., Massacesi, L., Chai, Y., Xu, L., Freeman, S. Efficacy Analysis of the Anti-LINGO-1 Monoclonal Antibody BIIB033 in Acute Optic Neuritis: the RENEW Trial Neurology 84 (2015). 


\section{Supplementary Tables}

\section{Supplementary Table 1: Clinical outcome measures in phase III trials in relapsing- remitting (RR) MS}

\begin{tabular}{|c|c|c|c|c|c|}
\hline $\begin{array}{l}\text { Original clinical } \\
\text { outcome }\end{array}$ & $\begin{array}{l}\text { Derived } \\
\text { outcome } \\
\text { measures }\end{array}$ & Trial & $\begin{array}{l}\text { Condition } \\
\text { (no. of } \\
\text { patients } \\
\text { randomised) }\end{array}$ & $\begin{array}{l}\text { Drug, effect } \\
\text { (vs. placebo/ } \\
\text { another active } \\
\text { arm) }\end{array}$ & $\begin{array}{l}\text { Duration of } \\
\text { the trial }\end{array}$ \\
\hline \multirow[t]{6}{*}{ Relapses } & $\begin{array}{l}\text { Mean } \\
\text { annualised } \\
\text { relapse rate (a) }\end{array}$ & $\begin{array}{l}\text { The IFNB Multiple } \\
\text { Sclerosis Study } \\
\text { Group, Neurology } \\
\text { 1993, phase III }\end{array}$ & $\begin{array}{l}\text { RRMS } \\
(n=372)\end{array}$ & $\begin{array}{l}\text { IFN beta-1b } 1.6 \\
\text { MIU: } 1.17, \mathrm{p} \\
\text { (vs. placebo) = } \\
0.0101 ; \\
\text { IFN beta-1b } 8 \\
\text { MIU: } 0.84, \mathrm{p} \\
\text { (vs. placebo) = } \\
0.0001 ; \mathrm{p} \text { (vs. } \\
1.6 \mathrm{MIU} \text { ) } \\
=0.0086 ; \\
\text { Placebo: } 1.27\end{array}$ & 24 months \\
\hline & & $\begin{array}{l}\text { Johnson et al., } \\
\text { Neurology 1995, } \\
\text { phase III (The } \\
\text { Copolymer } 1 \\
\text { Multiple Sclerosis } \\
\text { Study) }\end{array}$ & $\begin{array}{l}\text { RRMS } \\
(n=251)\end{array}$ & $\begin{array}{l}\text { Glatiramer } \\
\text { acetate } 20 \mathrm{mg} \\
\text { SC/day: } 0.59 ; \\
\text { Placebo: } 0.84, \\
p=0.007\end{array}$ & 24 months \\
\hline & & $\begin{array}{l}\text { Jacobs et al., Ann } \\
\text { Neurol 1996, phase } \\
\text { III (MSCRG study) }\end{array}$ & $\begin{array}{l}\text { Relapsing } \\
\text { MS }(n=301)\end{array}$ & $\begin{array}{l}\text { IFN beta-1a } \\
\text { 30mcg } \\
\text { IM/week: } 0.61 ; \\
\text { Placebo: } 0.9 \\
\text { p=0.03 }\end{array}$ & 104 weeks \\
\hline & & $\begin{array}{l}\text { PRISMS (Prevention } \\
\text { of Relapses and } \\
\text { Disability by } \\
\text { Interferon beta-1a } \\
\text { Subcutaneously in } \\
\text { Multiple Sclerosis) } \\
\text { Study Group, Lancet } \\
\text { 1998, phase III } \\
\text { (PRISMS study) }\end{array}$ & $\begin{array}{l}\text { RRMS } \\
(n=560)\end{array}$ & $\begin{array}{l}\text { Placebo: } 1.28 ; \\
\text { IFN beta-1a } \\
22 \mathrm{mcg} \text { SC tiw: } \\
0.91, \mathrm{p}<0.005 \\
\text { (vs. placebo); } \\
\text { IFN beta-1a } \\
44 \mathrm{mcg} \text { SC tiw: } \\
0.865, \mathrm{p}<0.005 \\
\text { (vs. placebo); } \\
\text { (s) }\end{array}$ & 24 months \\
\hline & & $\begin{array}{l}\text { Noseworthy et al., } \\
\text { Neurology 2000, } \\
\text { phase III (linomide } \\
\text { study) }\end{array}$ & RMS (n=715) & $\begin{array}{l}\text { The study was } \\
\text { of insufficient } \\
\text { duration for } \\
\text { any of the } \\
\text { primary or } \\
\text { secondary } \\
\text { outcome } \\
\text { measures to } \\
\text { reach } \\
\text { significance }\end{array}$ & $\begin{array}{l}\text { Early } \\
\text { termination } \\
\text { for safety } \\
\text { issues } \\
\text { (initially } \\
\text { planned: } 36 \\
\text { months) }\end{array}$ \\
\hline & & $\begin{array}{l}\text { Comi et al., Ann } \\
\text { Neurol 2001, phase }\end{array}$ & $\begin{array}{l}\text { RRMS } \\
(n=249)\end{array}$ & $\begin{array}{l}\text { Glatiramer } \\
\text { Acetate vs. }\end{array}$ & 9 months \\
\hline
\end{tabular}




\begin{tabular}{|c|c|c|c|c|c|}
\hline & & $\begin{array}{l}\text { III } \\
\text { (European/Canadian } \\
\text { Glatiramer Acetate } \\
\text { Study) }\end{array}$ & & $\begin{array}{l}\text { Glatiramer } \\
\text { acetate } 20 \mathrm{mg} \\
\text { SC/day: } 0.81 ; \\
\text { Placebo: } 1.21 \text {, } \\
p=0.012\end{array}$ & \\
\hline & & $\begin{array}{l}\text { Polman et al., NEJM } \\
\text { 2006, phase III } \\
\text { (AFFIRM study) }\end{array}$ & $\begin{array}{l}\text { RRMS } \\
(n=627)\end{array}$ & $\begin{array}{l}\text { Natalizumab } \\
\text { 300mg/4 } \\
\text { weeks: } 0.23 \\
\text { (0.19 to } 0.28) ; \\
\text { Placebo: } 0.73 \\
\text { (0.62 to } 0.87) \text {, } \\
p<0.001\end{array}$ & 24 months \\
\hline & & $\begin{array}{l}\text { Panitch et al., } \\
\text { Neurology 2002; } \\
\text { Schwid et al., } \\
\text { Clinical Therapeutics } \\
\text { 2007, phase } 4 \text { - } \\
\text { post- } \\
\text { commercialisation } \\
\text { (EVIDENCE study) }\end{array}$ & $\begin{array}{l}\text { RRMS } \\
(n=677)\end{array}$ & $\begin{array}{l}\text { IFN beta-1a IM } \\
\text { 30mcg/week: } \\
0.65 \text {; IFN beta- } \\
\text { 1a SC } 44 \mathrm{mcg} \\
\text { tiw: } 0.54 \\
p=0.033\end{array}$ & $\begin{array}{l}24 \text { months } \\
\text { (0-12m: } \\
\text { comparative } \\
\text { phase; } 12- \\
24 \mathrm{~m} \text { : cross- } \\
\text { over phase) } \\
\text { (n) }\end{array}$ \\
\hline & & $\begin{array}{l}\text { Rudick et al., NEJM } \\
\text { 2006, phase III } \\
\text { (SENTINEL study) }\end{array}$ & $\begin{array}{l}\text { RRMS } \\
(n=1171)\end{array}$ & $\begin{array}{l}\text { Natalizumab } \\
300 \mathrm{mg} / 4 \text { weeks } \\
+ \text { IFN beta-1a } \\
\text { IM } \\
30 \mathrm{mcg} / \text { week: } \\
0.34 \text { (0.29 to } \\
0.39) ; \text { IFN beta- } \\
1 \text { a IM } \\
30 \mathrm{mcg} / \text { week: } \\
0.75(0.67 \text { to } \\
0.84), p=0.001\end{array}$ & 24 months \\
\hline & & $\begin{array}{l}\text { O'Connor et al., } \\
\text { Lancet Neurol 2009, } \\
\text { phase III (BEYOND } \\
\text { study) }\end{array}$ & $\begin{array}{l}\text { RRMS } \\
(n=2244)\end{array}$ & $\begin{array}{l}\text { IFN beta-1b } \\
500 \mathrm{mcg} \text { SC eod: } \\
0.33 \text {; IFN beta- } \\
\text { 1b 250mcg SC } \\
\text { eod: } 0.36 ; \text { GA } \\
\text { 20mg SC/day: } \\
0.34, \text { p-values } \\
\text { (all } \\
\text { comparisons) > } \\
0.05\end{array}$ & 24 months \\
\hline & & $\begin{array}{l}\text { Cohen et al., NEJM } \\
\text { 2010, phase III } \\
\text { (TRANSFORMS } \\
\text { study) }\end{array}$ & $\begin{array}{l}\text { RRMS } \\
(n=1292)\end{array}$ & $\begin{array}{l}\text { Fingolimod } \\
0.5 \mathrm{mg} / \text { day: } \\
0.16 \text { ( } 0.12 \text { to } \\
0.21), \mathrm{p} \text { (vs. } \\
\text { IFN) <0.001; } \\
\text { Fingolimod } \\
1.25 \mathrm{mg} / \text { day: } \\
0.20 \text { (0.16 to } \\
0.26), \mathrm{p} \text { (vs. } \\
\text { IFN) <0.001; IFN } \\
\text { beta-1a IM } \\
30 \mathrm{mcg} / \text { week: } \\
0.33 \text { ( } 95 \% \mathrm{Cl} \\
0.26 \text { to } 0.42) ;\end{array}$ & 12 months \\
\hline & & Kappos et al., NEJM & RRMS & Fingolimod & 24 months \\
\hline
\end{tabular}




\begin{tabular}{|c|c|c|c|c|c|}
\hline & & $\begin{array}{l}\text { 2010, phase III } \\
\text { (FREEDOMS study) }\end{array}$ & $(n=1272)$ & $\begin{array}{l}0.5 \mathrm{mg} / \mathrm{day}: \\
0.18 \text { (0.15 to } \\
0.22), \mathrm{p} \text { (vs. } \\
\text { placebo) } \\
<0.001 ; \\
\text { Fingolimod } \\
1.25 \mathrm{mg} / \mathrm{day}: \\
0.16 \text { (0.13 to } \\
0.19), \mathrm{p} \text { (vs. } \\
\text { placebo) } \\
<0.001 ; \\
\text { Placebo: } 0.40 \\
\text { (95\% Cl } 0.34 \text { to } \\
0.47) ;\end{array}$ & \\
\hline & & $\begin{array}{l}\text { Giovannoni et al., } \\
\text { NEJM 2010, phase } \\
\text { III (CLARITY study) }\end{array}$ & $\begin{array}{l}\text { RRMS } \\
(n=1326)\end{array}$ & $\begin{array}{l}\text { Cladribine } \\
3.5 \mathrm{mg} / \mathrm{Kg}: 0.14 \\
\text { (0.12 to } 0.17), \mathrm{p} \\
\text { (vs. placebo) } \\
\text { <0.001; } \\
\text { Cladribine } \\
5.25 \mathrm{mg} / \mathrm{Kg} \text { : } \\
0.15 \text { (0.12 to } \\
0.17), \mathrm{p} \text { (vs. } \\
\text { placebo) } \\
<0.001 ; \\
\text { Placebo: } 0.33 \\
\text { (95\% Cl } 0.29 \text { to } \\
0.38) ;\end{array}$ & 96 weeks \\
\hline & & $\begin{array}{l}\text { Comi at el., Ann } \\
\text { Neurol 2011, phase } \\
\text { III (FORTE study) }\end{array}$ & $\begin{array}{l}\text { RRMS } \\
(n=1155)\end{array}$ & $\begin{array}{l}\text { GA 20mg } \\
\text { SC/day: } 0.33 \\
\text { (SD 0.81); GA } \\
\text { 40mg SC/day: } \\
0.35 \text { (SD 0.99), } \\
p=0.486\end{array}$ & 12 months \\
\hline & & $\begin{array}{l}\text { O'Connor et al., } \\
\text { NEJM 2011, phase } \\
\text { III (TEMSO study) }\end{array}$ & $\begin{array}{l}\text { Relapsing } \\
\text { MS ( } n=1088)\end{array}$ & $\begin{array}{l}\text { Teriflunomide } \\
7 \mathrm{mg} \text { PO/day: } \\
0.37 \text { (0.32- } \\
0.43), \mathrm{p} \text { (vs. } \\
\text { placebo) } \\
<0.001 ; \\
\text { Teriflunomide } \\
14 \mathrm{mg} \text { PO/day: } \\
0.37 \text { (0.31- } \\
0.44), \mathrm{p} \text { (vs. } \\
\text { placebo) } \\
<0.001 ; \\
\text { Placebo: } 0.54 \\
(0.47-0.62 \text { ) }\end{array}$ & 108 weeks \\
\hline & & $\begin{array}{l}\text { Sorensen et al., } \\
\text { Lancet Neurology } \\
\text { 2011, phase } 4 \\
\text { (SIMCOMBIN study) }\end{array}$ & $\begin{array}{l}\text { RRMS } \\
(n=307)\end{array}$ & $\begin{array}{l}\text { IFN beta-1a } \\
30 \mathrm{mcg} \\
\text { IM/week + } \\
\text { simvastatin } \\
80 \mathrm{mg} / \text { day: } \\
0.188(95 \% \mathrm{Cl} \\
0.126 \text { to } 0.281) \text {; } \\
\text { IFN beta-1a }\end{array}$ & $\begin{array}{l}12 \text { months } \\
\text { after last } \\
\text { patient was } \\
\text { included }\end{array}$ \\
\hline
\end{tabular}




\begin{tabular}{|c|c|c|c|c|c|}
\hline & & & & $\begin{array}{l}30 \mathrm{mcg} \\
\text { IM/week + } \\
\text { Placebo: } 0.144 \\
(95 \% \mathrm{Cl} 0.092 \\
\text { to } 0.227), \mathrm{p}= \\
0.35\end{array}$ & \\
\hline & & $\begin{array}{l}\text { Cohen et al., Lancet } \\
\text { 2012, phase III } \\
\text { (CARE-MS I study) }\end{array}$ & $\begin{array}{l}\text { RRMS } \\
\text { previously } \\
\text { untreated } \\
(n=581)\end{array}$ & $\begin{array}{l}\text { Alemtuzumab } \\
12 \mathrm{mg} \text { IV/day } \mathrm{x} \\
5 \text { days: } 0.18 \\
\text { ( } 0.13 \text { to } 0.23 \text { ); } \\
\text { IFN beta-1a } \\
44 \mathrm{mcg} \mathrm{SC} \text { tiw: } \\
0.39 \text { ( } 95 \% \mathrm{Cl} \text { : } \\
0.29 \text { to } 0.53 \text { ), } \\
\text { p<0.0001 }\end{array}$ & 24 months \\
\hline & & $\begin{array}{l}\text { Coles et al., Lancet } \\
\text { 2012, phase III } \\
\text { (CARE-MS II study) }\end{array}$ & $\begin{array}{l}\text { RRMS } \\
\text { previously } \\
\text { treated } \\
(\mathrm{n}=840)\end{array}$ & $\begin{array}{l}\text { Alemtuzumab } \\
12 \mathrm{mg} \text { IV/day } x \\
5 \text { days: } 0.26 \\
\text { (95\% Cl } 0.21 \text { to } \\
0.33 \text { ); IFN beta } \\
1 \text { a } 44 \mathrm{mcg} \text { SC } \\
\text { tiw: } 0.52 \text { (95\% } \\
\text { Cl } 0.41 \text { to } 0.66) \text {, } \\
\text { p<0.0001 }\end{array}$ & 24 months \\
\hline & & $\begin{array}{l}\text { Comi et al., NEJM } \\
\text { 2012, phase III } \\
\text { (ALLEGRO study) }\end{array}$ & $\begin{array}{l}\text { RRMS } \\
(n=1106)\end{array}$ & $\begin{array}{l}\text { Laquinimod } \\
0.6 \mathrm{mg} \text { OD: } 0.30 \\
\text { (SE 0.02), p (vs. } \\
\text { placebo) } \\
=0.002 ; \\
\text { Placebo: } 0.39 \\
\text { (SE 0.03); }\end{array}$ & 24 months \\
\hline & & $\begin{array}{l}\text { Fox et al., NEJM } \\
\text { 2012, phase III } \\
\text { (CONFIRM study) }\end{array}$ & $\begin{array}{l}\text { RRMS } \\
(n=1417)\end{array}$ & $\begin{array}{l}\text { BG-12 240mg } \\
\text { BD: } 0.22 \text { ( } 95 \% \\
\text { Cl } 0.18 \text { to } 0.28 \text { ), } \\
\text { p (vs. placebo) } \\
<0.001 ; \mathrm{BG}-12 \\
240 \mathrm{mg} \text { TDS: } \\
0.20 \text { ( } 95 \% \mathrm{Cl} \\
0.16 \text { to } 0.25), \mathrm{p} \\
\text { (vs. placebo) } \\
<0.001 ; \mathrm{GA} \\
40 \mathrm{mg} \mathrm{SC} / \text { day: } \\
0.29 \text { ( } 95 \% \mathrm{Cl} \\
0.23 \text { to } 0.35), \mathrm{p} \\
\text { (vs. placebo) } \\
<0.05 ; \text { Placebo: } \\
0.40 \text { (95\% Cl } \\
0.33 \text { to } 0.49 \text { ); }\end{array}$ & 24 months \\
\hline & & $\begin{array}{l}\text { Gold et al., NEJM } \\
\text { 2012, phase III } \\
\text { (DEFINE study) }\end{array}$ & $\begin{array}{l}\text { RRMS } \\
(n=1234)\end{array}$ & $\begin{array}{l}\text { BG-12 240mg } \\
\text { BD: } 0.17 \text { (95\% } \\
\text { Cl 0.14 to 0.21), } \\
\text { p (vs. placebo) } \\
<0.001 ; \text { BG-12 } \\
240 \mathrm{mg} \text { TDS: } \\
0.19 \text { (95\% Cl } \\
0.15 \text { to } 0.23), \mathrm{p}\end{array}$ & 24 months \\
\hline
\end{tabular}




\begin{tabular}{|c|c|c|c|c|c|}
\hline & & & & $\begin{array}{l}\text { (vs. placebo) } \\
<0.001 ; \\
\text { Placebo: } 0.36 \\
(95 \% \text { Cl } 0.30 \text { to } \\
0.44) ;\end{array}$ & \\
\hline & & $\begin{array}{l}\text { Khan et al., Ann } \\
\text { Neurol 2013, phase } \\
\text { III (GALA study) }\end{array}$ & $\begin{array}{l}\text { RRMS } \\
(n=1404)\end{array}$ & $\begin{array}{l}\text { GA } 40 \mathrm{mg} \mathrm{SC} \\
\text { tiw: } 0.331(95 \% \\
\text { Cl } 0.280 \text { to } \\
0.392) \text { vs. } \\
\text { placebo: } 0.505 \\
(0.418 \text { to } \\
0.609) \\
\text { p<0.0001 }\end{array}$ & 12 months \\
\hline & & $\begin{array}{l}\text { Lublin et al., Ann } \\
\text { Neurol 2013, phase } \\
\text { III (CombiRx study) }\end{array}$ & $\begin{array}{l}\text { RRMS } \\
(n=1008)\end{array}$ & $\begin{array}{l}\text { IFN beta-1a } \\
30 \mathrm{mcg} \text { SC/week } \\
+ \text { GA } 20 \mathrm{mg} \\
\text { SC/day: } 0.23 \text { vs. } \\
\text { IFN: } 0.32 \\
p=0.001 ; \\
\text { IFN+GA: } 0.23 \\
\text { vs. GA: } 0.23 \\
p=0.44 ; \text { IFN vs. } \\
\text { GA: } p=0.008\end{array}$ & $\begin{array}{l}36 \text { months } \\
\text { after last } \\
\text { patient was } \\
\text { included }\end{array}$ \\
\hline & & $\begin{array}{l}\text { Calabresi et al. } \\
\text { Lancet Neurol 2014, } \\
\text { phase III (ADVANCE } \\
\text { study) }\end{array}$ & $\begin{array}{l}\text { RRMS } \\
(n=1516)\end{array}$ & $\begin{array}{l}\text { Peginterferon } \\
\text { beta-1a } \\
125 \mathrm{mcg} \mathrm{SC} / 2 \\
\text { weeks vs. } \\
\text { placebo: } 0.256 \\
(0.206-0.318) \\
\text { vs. } 0.397 \\
(0.328-0.481) \text {, } \\
p=0.0007 ; \\
\text { Peginterferon } \\
\text { beta-1a } \\
125 \mathrm{mcg} \mathrm{SC} / 4 \\
\text { weeks vs. } \\
\text { placebo: } 0.288 \\
(0.234-0.355) \\
\text { vs. } 0.397 \\
(0.328-0.481) \\
p=0.0114\end{array}$ & $\begin{array}{l}24 \text { months } \\
\text { (but } \\
\text { primary } \\
\text { endpoint: } \\
48 \text { weeks, } \\
\text { which is the } \\
\text { placebo- } \\
\text { controlled } \\
\text { phase) }\end{array}$ \\
\hline & & $\begin{array}{l}\text { Calabresi et al., } \\
\text { Lancet Neurol 2014, } \\
\text { phase III } \\
\text { (FREEDOMS II study) }\end{array}$ & $\begin{array}{l}\text { RRMS } \\
(n=1083)\end{array}$ & $\begin{array}{l}\text { Fingolimod } \\
0.5 \mathrm{mg}: 0.21 \\
(0.17-0 \cdot 25) \\
\text { placebo: } 0.40 \\
(95 \% \mathrm{Cl} 0.34- \\
0.48), \mathrm{p}<0.0001\end{array}$ & 24 months \\
\hline & & $\begin{array}{l}\text { Confavreux et al., } \\
\text { Lancet Neurol 2014, } \\
\text { phase III (TOWER } \\
\text { study) }\end{array}$ & $\begin{array}{l}\text { RRMS } \\
(n=1169)\end{array}$ & $\begin{array}{l}\text { Teriflunomide } \\
\text { 7mg: } 0.39 \\
(0.33-0.46) ; p \\
\text { (vs. placebo) } \\
=0.0183 \\
\text { Teriflunomide } \\
14 \mathrm{mg}: 0.32 \\
\text { (0.27-0.38); } \mathrm{p} \\
\text { (vs. placebo) }\end{array}$ & $\begin{array}{l}48 \text { weeks } \\
\text { after the } \\
\text { last patient } \\
\text { was } \\
\text { included } \\
\text { (MRI results } \\
\text { not } \\
\text { published) }\end{array}$ \\
\hline
\end{tabular}




\begin{tabular}{|c|c|c|c|c|c|}
\hline & & & & $\begin{array}{l}=0.0001 \\
\text { Placebo: } 0.50 \\
(95 \% \text { Cl } 0.43- \\
0.58)\end{array}$ & \\
\hline & & $\begin{array}{l}\text { Massacesi et al., } \\
\text { PLoS ONE 2014, } \\
\text { phase III }\end{array}$ & $\begin{array}{l}\text { RRMS } \\
(n=150)\end{array}$ & $\begin{array}{l}\text { Azathioprine } \\
\text { (target dose: } 3 \\
\mathrm{mg} / \mathrm{kg} / \mathrm{d} \text { ) vs. } \\
\text { BIFN beta (1a } \\
\text { or } 1 \mathrm{~b}): 0.26 \\
(95 \% \mathrm{Cl}: 0.19- \\
0.37) \text { vs. } 0.39 \\
(95 \% \mathrm{Cl}: 0.30- \\
0.51), \mathrm{p}=0.07\end{array}$ & 24 months \\
\hline & & $\begin{array}{l}\text { Mikol et al., Lancet } \\
\text { Neurol 2014, phase } \\
\text { III (REGARD study) }\end{array}$ & $\begin{array}{l}\text { RRMS } \\
(n=764)\end{array}$ & $\begin{array}{l}\text { IFN beta-1a } \\
44 \mathrm{mcg} \text { SC tiw: } \\
0.30, \text { vs. } \\
\text { Glatiramer } \\
\text { acetate } 20 \mathrm{mg} \\
\text { SC/day: } 0.29 ; \mathrm{p} \\
=0.828\end{array}$ & 96 weeks \\
\hline & & $\begin{array}{l}\text { Vermersch et al., } \\
\text { MSJ 2014, phase III } \\
\text { (TENERE study) }\end{array}$ & $\begin{array}{l}\text { Relapsing } \\
\text { MS }(n=324)\end{array}$ & $\begin{array}{l}\text { Teriflunomide } \\
\text { 7mg: } 0.41 \text { ( } 0.27 \\
\text { to } 0.64), \mathrm{p} \text { (vs. } \\
\text { IFN) =0.03; } \\
\text { Teriflunomide } \\
\text { 14mg: } 0.26 \\
\text { ( } 0.15 \text { to } 0.44), \mathrm{p} \\
\text { (vs. IFN) }=0.59 ; \\
\text { IFN beta-1a: } \\
0.22(0.11 \text { to } \\
0.42 \text { ); }\end{array}$ & $\begin{array}{l}48 \text { weeks } \\
\text { after the } \\
\text { last patient } \\
\text { was } \\
\text { included }\end{array}$ \\
\hline & & $\begin{array}{l}\text { Vollmer et al., J } \\
\text { Neurol 2014, phase } \\
\text { III (BRAVO study) }\end{array}$ & $\begin{array}{l}\text { RRMS } \\
(n=1331)\end{array}$ & $\begin{array}{l}\text { Laquinimod } \\
0.6 \mathrm{mg}: 0.28 \\
(0.03) ; \\
\text { IFN-beta } 30 \\
\text { mcg IM: } 0.26 \\
\text { (0.02); } \\
\text { Placebo: } 0.34 \\
\text { (0.03); } \\
\text { p (Laq vs. } \\
\text { placebo) }=0.075 ; \\
\text { p (IFN vs. } \\
\text { placebo) }=0.007\end{array}$ & 24 months \\
\hline & & $\begin{array}{l}\text { Cohen et al., JAMA } \\
\text { Neurol 2015, phase } \\
\text { III (GATE study) }\end{array}$ & $\begin{array}{l}\text { RRMS } \\
(n=796)\end{array}$ & $\begin{array}{l}\text { Generic GA } \\
20 \mathrm{mg} / \mathrm{d} \text { vs. } \\
\text { brand GA } \\
20 \mathrm{mg} / \mathrm{d} \text { vs. } \\
\text { placebo: } 0.31 \\
\text { (0.20 to } 0.48) \\
\text { vs. } 0.40(0.26 \text { to } \\
0.62) \text { vs. } 0.38 \\
(0.22 \text { to } 0.66) \\
\text { (ns) }\end{array}$ & 9 months \\
\hline & & $\begin{array}{l}\text { Kappos et al., New } \\
\text { Engl J Med 2015, } \\
\text { phase III (DECIDE }\end{array}$ & $\begin{array}{l}\text { RRMS } \\
(n=1841)\end{array}$ & $\begin{array}{l}\text { Daclizumab HYP } \\
\text { 150mg SC/4 } \\
\text { weeks vs. IFN }\end{array}$ & 144 weeks \\
\hline
\end{tabular}




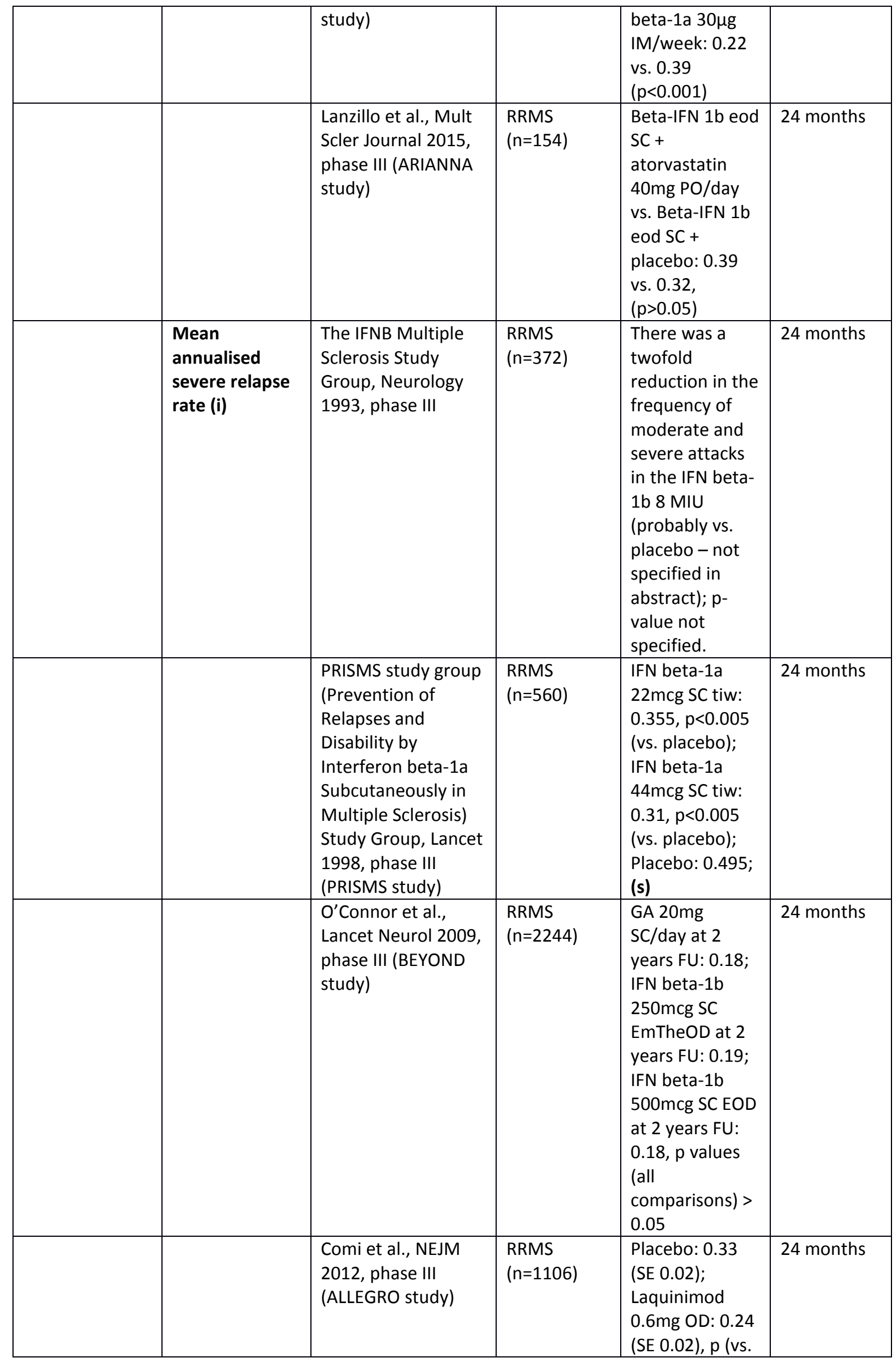




\begin{tabular}{|c|c|c|c|c|c|}
\hline & & & & $\begin{array}{l}\text { placebo) } \\
<0.001 ;\end{array}$ & \\
\hline & & $\begin{array}{l}\text { Khan et al., Ann } \\
\text { Neurol 2013, phase } \\
\text { III (GALA study) }\end{array}$ & $\begin{array}{l}\text { RRMS } \\
(n=1404)\end{array}$ & $\begin{array}{l}\text { GA } 40 m g \text { sc tiw: } \\
0.301(95 \% \mathrm{Cl} \\
0.252 \text { to } 0.359) \\
\text { vs. placebo: } \\
0.466(0.383 \text { to } \\
0.568) \\
p<0.0001\end{array}$ & 12 months \\
\hline & $\begin{array}{l}\% \text { patients with } \\
\text { at least } 1 \\
\text { relapse }(\mathrm{a})(\mathrm{I})\end{array}$ & $\begin{array}{l}\text { O'Connor et al., } \\
\text { Lancet Neurol 2009, } \\
\text { phase III (BEYOND } \\
\text { study) (m) }\end{array}$ & $\begin{array}{l}\text { RRMS } \\
(n=2244)\end{array}$ & $\begin{array}{l}\text { GA } 20 \mathrm{mg} \\
\text { SC/day at } 2 \\
\text { years FU: } 27 \% \text {; } \\
\text { IFN beta-1b } \\
250 \mathrm{mcg} \text { SC eod } \\
\text { at } 2 \text { years FU: } \\
27 \% \text {; IFN beta- } \\
1 \mathrm{~b} 500 \mathrm{mcg} \text { SC } \\
\text { eod at } 2 \text { years } \\
\text { FU: } 26 \%, p- \\
\text { values (all } \\
\text { comparisons) > } \\
0.05\end{array}$ & 24 months \\
\hline & & $\begin{array}{l}\text { Fox et al., NEJM } \\
\text { 2012, phase III } \\
\text { (CONFIRM study) }\end{array}$ & $\begin{array}{l}\text { RRMS } \\
(n=1417)\end{array}$ & 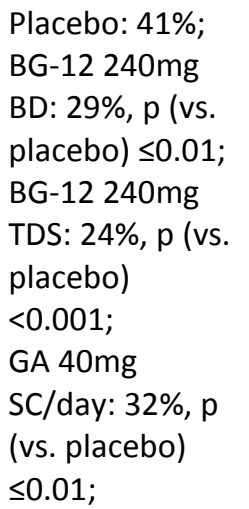 & 24 months \\
\hline & & $\begin{array}{l}\text { Gold et al., NEJM } \\
\text { 2012, phase III } \\
\text { (DEFINE study) }\end{array}$ & $\begin{array}{l}\text { RRMS } \\
(n=1234)\end{array}$ & $\begin{array}{l}\text { Placebo: 46\%; } \\
\text { BG-12 240mg } \\
\text { BD: } 27 \%, p \text { (vs. } \\
\text { placebo) } \\
<0.001 ; \text { BG-12 } \\
240 m g \text { TDS: } \\
26 \% \text {, p (vs. } \\
\text { placebo) } \\
<0.001 ;\end{array}$ & 24 months \\
\hline & & $\begin{array}{l}\text { Lublin et al., Ann } \\
\text { Neurol 2013, phase } \\
\text { III (CombiRx study) }\end{array}$ & $\begin{array}{l}\text { RRMS } \\
(n=1008)\end{array}$ & $\begin{array}{l}\text { IFN+GA: } 38.9 \% \\
\text { vs. IFN: } 44.4 \%, \\
p=0.19 \\
\text { IFN+GA: } 38.9 \% \\
\text { vs. GA: } 35.9 \% \text {, } \\
p=0.21 \\
\text { IFN: } 44.4 \% \text { vs. } \\
G A: 35.9 \%, \\
p=0.14\end{array}$ & $\begin{array}{l}36 \text { months } \\
\text { after last } \\
\text { patient was } \\
\text { included }\end{array}$ \\
\hline & & $\begin{array}{l}\text { Calabresi et al. } \\
\text { Lancet Neurol 2014, } \\
\text { phase III (ADVANCE } \\
\text { study) }\end{array}$ & $\begin{array}{l}\text { RRMS } \\
(n=1516)\end{array}$ & $\begin{array}{l}\text { Peginterferon } \\
\text { beta-1a } \\
125 \mu \mathrm{g} / 2 \text { weeks } \\
\text { SC vs. placebo: }\end{array}$ & $\begin{array}{l}24 \text { months } \\
\text { (but } \\
\text { primary } \\
\text { endpoint: }\end{array}$ \\
\hline
\end{tabular}




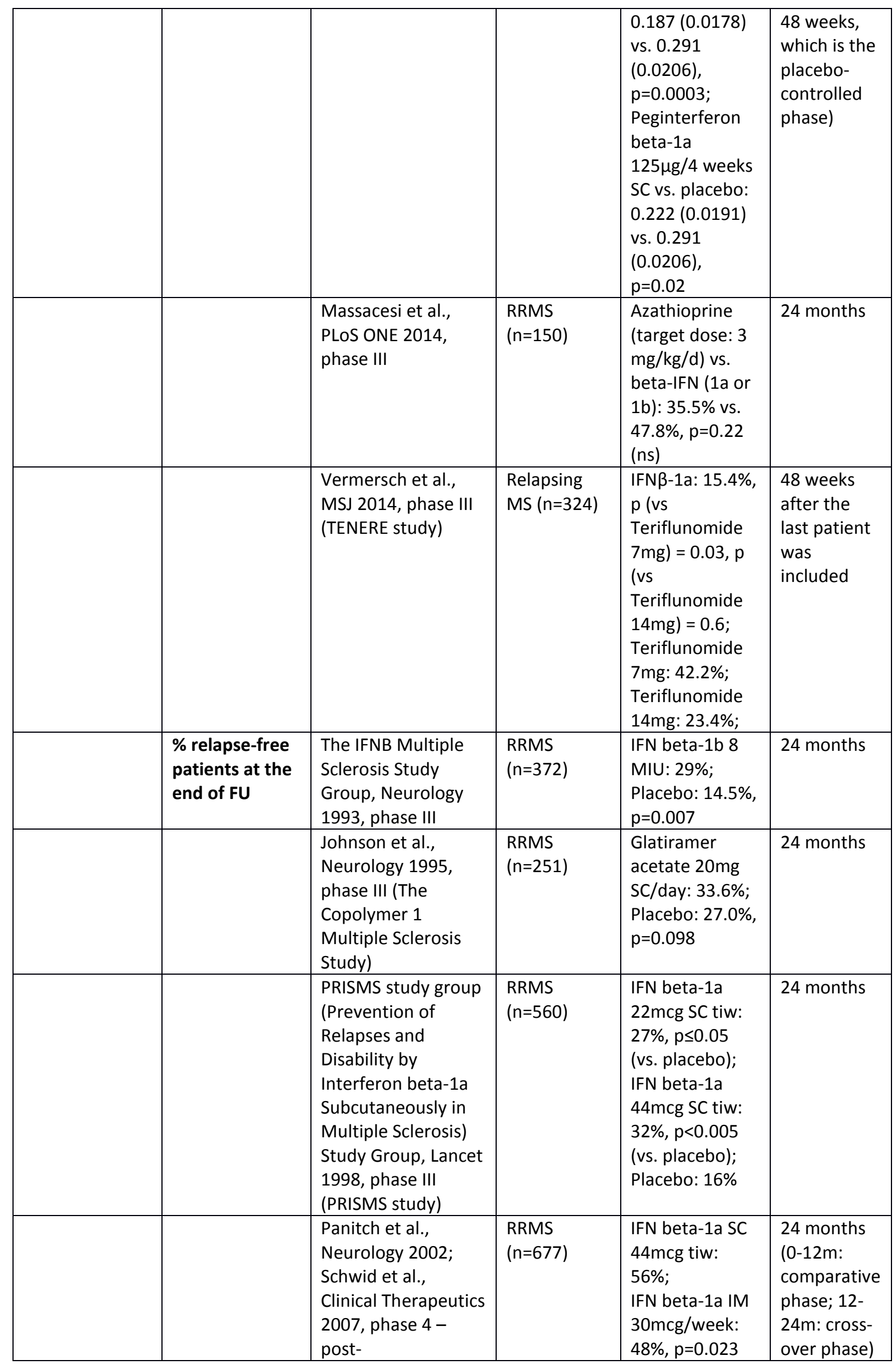




\begin{tabular}{|c|c|c|c|c|c|}
\hline & & $\begin{array}{l}\text { commercialisation } \\
\text { (EVIDENCE study) }\end{array}$ & & & (n) \\
\hline & & $\begin{array}{l}\text { Polman et al., NEJM } \\
\text { 2006, phase III } \\
\text { (AFFIRM study) }\end{array}$ & $\begin{array}{l}\text { RRMS } \\
(n=627)\end{array}$ & $\begin{array}{l}\text { Natalizumab } \\
300 \mathrm{mg} / 4 \\
\text { weeks: } 72 \%, \mathrm{p} \\
\text { (vs. placebo) } \\
<0.05 ; \\
\text { Placebo: } 46 \% \\
\text { (o) }\end{array}$ & 24 months \\
\hline & & $\begin{array}{l}\text { Rudick et al., NEJM } \\
\text { 2006, phase III } \\
\text { (SENTINEL study) }\end{array}$ & $\begin{array}{l}\text { RRMS } \\
(n=1171)\end{array}$ & $\begin{array}{l}\text { Natalizumab } \\
300 \mathrm{mg} / 4 \text { weeks } \\
+ \text { IFN beta-1a } \\
\text { IM } \\
30 \mathrm{mcg} / \text { week: } \\
61 \%, \mathrm{p} \text { (vs. IFN) } \\
<0.05 ; \\
\text { IFN beta-1a IM } \\
30 \mathrm{mcg} / \text { week: } \\
37 \% \text { (o) }\end{array}$ & 24 months \\
\hline & & $\begin{array}{l}\text { Cohen et al., NEJM } \\
\text { 2010, phase III } \\
\text { (TRANSFORMS } \\
\text { study) }\end{array}$ & $\begin{array}{l}\text { RRMS } \\
(n=1292)\end{array}$ & $\begin{array}{l}\text { Fingolimod } \\
0.5 \mathrm{mg} / \text { day: } \\
82.6 \% \text { (79.0 to } \\
86.3 \text { ), p (vs. } \\
\text { IFN)<0.001; } \\
\text { Fingolimod } \\
1.25 \mathrm{mg} / \text { day: } \\
79.8 \% \text { (75.9 to } \\
83.7), \mathrm{p} \text { (vs. } \\
\text { IFN) <0.001; } \\
\text { IFN beta-1a IM } \\
30 \mathrm{mcg} / \text { week: } \\
69.3 \% \text { (95\% Cl } \\
64.8 \text { to } 73.8)\end{array}$ & 12 months \\
\hline & & $\begin{array}{l}\text { O'Connor et al., } \\
\text { Lancet Neurol 2009, } \\
\text { phase III (BEYOND } \\
\text { study) }\end{array}$ & $\begin{array}{l}\text { RRMS } \\
(n=2244)\end{array}$ & $\begin{array}{l}\text { IFN beta-1b } \\
500 \mathrm{mcg} \text { SC eod } \\
\text { at } 2 \text { years FU: } \\
60 \% \text {; } \\
\text { IFN beta-1b } \\
250 \mathrm{mcg} \text { SC eod } \\
\text { at } 2 \text { years FU: } \\
58 \% \text {; } \\
\text { GA } 20 \mathrm{mg} \\
\text { SC/day at } 2 \\
\text { years FU: } 59 \% \text {, } \\
\text { p values (all } \\
\text { comparisons) > } \\
0.05\end{array}$ & 24 months \\
\hline & & $\begin{array}{l}\text { Kappos et al., NEJM } \\
\text { 2010, phase III } \\
\text { (FREEDOMS study) }\end{array}$ & $\begin{array}{l}\text { RRMS } \\
(n=1272)\end{array}$ & $\begin{array}{l}\text { Fingolimod } \\
0.5 \mathrm{mg} / \text { day: } \\
70.4 \% \text { (66.0 to } \\
74.8 \text { ), p (vs. } \\
\text { placebo) }<0.001 \\
\text { Fingolimod } \\
1.25 \mathrm{mg} / \text { day: } \\
74.7 \% \text { ( } 70.4 \text { to }\end{array}$ & 24 months \\
\hline
\end{tabular}




\begin{tabular}{|c|c|c|c|c|c|}
\hline & & & & $\begin{array}{l}78.9 \text { ), p (vs. } \\
\text { placebo) }<0.001 \\
\text { Placebo: } 45.6 \% \\
(95 \% \mathrm{Cl} 40.7 \text { to } \\
50.6)\end{array}$ & \\
\hline & & $\begin{array}{l}\text { Giovannoni et al., } \\
\text { NEJM 2010, phase } \\
\text { III (CLARITY study) }\end{array}$ & $\begin{array}{l}\text { RRMS } \\
(n=1326)\end{array}$ & $\begin{array}{l}\text { Cladribine } \\
3.5 \mathrm{mg} / \mathrm{Kg} \text { : } \\
79.7 \%, \mathrm{p} \text { (vs. } \\
\text { placebo) } \\
<0.001 ; \\
\text { Cladribine } \\
5.25 \mathrm{mg} / \mathrm{Kg}: \\
78.9 \%, \mathrm{p} \text { (vs. } \\
\text { placebo) } \\
<0.001 ; \\
\text { Placebo: } 60.9 \%\end{array}$ & 96 weeks \\
\hline & & $\begin{array}{l}\text { Comi at el., Ann } \\
\text { Neurol 2011, phase } \\
\text { III (FORTE study) }\end{array}$ & $\begin{array}{l}\text { RRMS } \\
(n=1155)\end{array}$ & $\begin{array}{l}\text { GA 20mg } \\
\text { SC/day: 77.6\% } \\
\text { (SD 17.4); GA } \\
\text { 40mg SC/day: } \\
77.0 \% \text { (SD } \\
\text { 17.7), p=0.999 }\end{array}$ & 12 months \\
\hline & & $\begin{array}{l}\text { O'Connor et al., } \\
\text { NEJM 2011, phase } \\
\text { III (TEMSO study) }\end{array}$ & $\begin{array}{l}\text { Relapsing } \\
\text { MS (n=1088) }\end{array}$ & $\begin{array}{l}\text { Teriflunomide } \\
7 \mathrm{mg} \mathrm{PO/day:} \\
53.7 \% \text { (48.3- } \\
59.1), \mathrm{p} \text { (vs. } \\
\text { placebo) =0.01; } \\
\text { Teriflunomide } \\
14 \mathrm{mg} \text { PO/day: } \\
56.5 \% \text { (51.0- } \\
62.0), \text { p (vs. } \\
\text { placebo) } \\
=0.003 ; \\
\text { Placebo: } 45.6 \% \\
\text { (95\% Cl: } 40.2- \\
51.0)\end{array}$ & 108 weeks \\
\hline & & $\begin{array}{l}\text { Sorensen et al., } \\
\text { Lancet Neurology } \\
2011 \text {, phase } 4 \\
\text { (SIMCOMBIN study) }\end{array}$ & $\begin{array}{l}\text { RRMS } \\
(n=307)\end{array}$ & $\begin{array}{l}\text { IFN beta-1a } \\
30 \mathrm{mcg} \\
\text { IM/week + } \\
\text { simvastatin } \\
80 \mathrm{mg} / \text { day: } \\
75 \% \text {; } \\
\text { IFN beta-1a } \\
30 \mathrm{mcg} \\
\text { IM/week + } \\
\text { Placebo: } 81 \%, \mathrm{p} \\
=0.512\end{array}$ & $\begin{array}{l}12 \text { months } \\
\text { after last } \\
\text { patient was } \\
\text { included }\end{array}$ \\
\hline & & $\begin{array}{l}\text { Cohen et al., Lancet } \\
\text { 2012, phase III } \\
\text { (CARE-MS I study) }\end{array}$ & $\begin{array}{l}\text { RRMS } \\
\text { previously } \\
\text { untreated } \\
(n=581)\end{array}$ & $\begin{array}{l}\text { Alemtuzumab } \\
12 \mathrm{mg} \text { IV/day x } \\
5 \text { days: } 77.6 \% \\
\text { ( } 72.9 \text { to } 81.6) ; \\
\text { IFN beta } 1 \mathrm{a} \\
44 \mathrm{mcg} \mathrm{SC} \text { tiw: } \\
58.7 \% \text { ( } 95 \% \mathrm{Cl} \text { : } \\
51.1 \text { to } 65.5) \text {, } \\
\text { p<0.0001 }\end{array}$ & 24 months \\
\hline
\end{tabular}




\begin{tabular}{|c|c|c|c|c|c|}
\hline & & $\begin{array}{l}\text { Coles et al., Lancet } \\
\text { 2012, phase III } \\
\text { (CARE-MS II study) }\end{array}$ & $\begin{array}{l}\text { RRMS } \\
\text { previously } \\
\text { treated } \\
(\mathrm{n}=840)\end{array}$ & $\begin{array}{l}\text { Alemtuzumab } \\
12 \mathrm{mg} \text { IV/day x } \\
5 \text { days: } 65.4 \% \\
\text { ( } 95 \% \mathrm{Cl} 60.7 \text { to } \\
69.7) ; \\
\text { IFN beta } 1 \mathrm{a} \\
44 \mathrm{mcg} \mathrm{SC} \text { tiw: } \\
46.7 \%(95 \% \mathrm{Cl} \\
39.5 \text { to } 53.5) \text {, } \\
\text { p<0.0001; }\end{array}$ & 24 months \\
\hline & & $\begin{array}{l}\text { Comi et al., NEJM } \\
\text { 2012, phase III } \\
\text { (ALLEGRO study) }\end{array}$ & $\begin{array}{l}\text { RRMS } \\
(n=1106)\end{array}$ & $\begin{array}{l}\text { Laquinimod } \\
0.6 \mathrm{mg} \text { OD: } \\
52.24 \% ; \\
\text { Placebo: } \\
62.90 \% \text {, p (vs. } \\
\text { placebo) } \\
<0.001 ;\end{array}$ & 24 months \\
\hline & & $\begin{array}{l}\text { Khan et al., Ann } \\
\text { Neurol 2013, phase } \\
\text { III (GALA study) }\end{array}$ & $\begin{array}{l}\text { RRMS } \\
(n=1404)\end{array}$ & $\begin{array}{l}\text { GA 40mg sc tiw: } \\
77.0 \% \text { vs. } \\
\text { Placebo: } 65.5 \% \text {, } \\
\text { p<0.0001 }\end{array}$ & 12 months \\
\hline & & $\begin{array}{l}\text { Lublin et al., Ann } \\
\text { Neurol 2013, phase } \\
\text { III (CombiRx study) }\end{array}$ & $\begin{array}{l}\text { RRMS } \\
(n=1008)\end{array}$ & $\begin{array}{l}\text { IFN+GA: } 61.1 \% \\
\text { vs. IFN: } 55.6 \% \\
p=0.19 \\
\text { IFN+GA: } 61.1 \% \\
\text { vs. GA: } 64.1 \% \text {, } \\
p=0.21 \\
\text { IFN: } 55.6 \% \text { vs. } \\
\text { GA: } 64.1 \% \\
p=0.14\end{array}$ & $\begin{array}{l}36 \text { months } \\
\text { after last } \\
\text { patient was } \\
\text { included }\end{array}$ \\
\hline & & $\begin{array}{l}\text { Calabresi et al., } \\
\text { Lancet Neurol 2014, } \\
\text { phase III } \\
\text { (FREEDOMS II study) }\end{array}$ & $\begin{array}{l}\text { RRMS } \\
(n=1083)\end{array}$ & $\begin{array}{l}\text { Fingolimod } \\
0.5 \mathrm{mg}: 71.5 \% \\
\text { (66.6 to } 76.4 \text { ); } \\
\text { Placebo: } 52.7 \% \\
\text { (2.8; } 47.2 \text { to } \\
58.2 \text { ), } p<0.0001\end{array}$ & 24 months \\
\hline & & $\begin{array}{l}\text { Confavreux et al., } \\
\text { Lancet Neurol 2014, } \\
\text { phase III (TOWER } \\
\text { study) }\end{array}$ & $\begin{array}{l}\text { RRMS } \\
(n=1169)\end{array}$ & $\begin{array}{l}\text { Teriflunomide } \\
7 \mathrm{mg}: 71.9 \% \\
\text { (67.3 to } 76.5 \text { ), p } \\
\text { (vs. placebo) } \\
=0.016 \\
\text { Teriflunomide } \\
14 \mathrm{mg}: 76.3 \% \\
\text { (71.7 to } 81.0 \text { ), p } \\
\text { (vs. placebo) } \\
<0.0001 \\
\text { Placebo: } 60.6 \% \\
\text { (95\% Cl: } 55.5 \text { to } \\
65.6) ;\end{array}$ & $\begin{array}{l}48 \text { weeks } \\
\text { after the } \\
\text { last patient } \\
\text { was } \\
\text { included }\end{array}$ \\
\hline & & $\begin{array}{l}\text { Massacesi et al., } \\
\text { PLoS ONE 2014, } \\
\text { phase III }\end{array}$ & $\begin{array}{l}\text { RRMS } \\
(n=150)\end{array}$ & $\begin{array}{l}\text { Azathioprine } \\
\text { (target dose: } 3 \\
\mathrm{mg} / \mathrm{kg} / \mathrm{d} \text { ) vs. } \\
\text { IFN beta (1a or } \\
\text { 1b): } 62.9 \% \text { vs. } \\
47.7 \%, \mathrm{p}=0.22 \\
\text { (ns) }\end{array}$ & 24 months \\
\hline
\end{tabular}




\begin{tabular}{|c|c|c|c|c|}
\hline & $\begin{array}{l}\text { Mikol et al., Lancet } \\
\text { Neurol 2014, phase } \\
\text { III (REGARD study) }\end{array}$ & $\begin{array}{l}\text { RRMS } \\
(n=764)\end{array}$ & $\begin{array}{l}\text { IFN beta-1a } \\
44 \mathrm{mcg} \text { SC tiw: } \\
62 \% ; \\
\text { Glatiramer } \\
\text { acetate } 20 \mathrm{mg} \\
\text { SC/day: } 62 \% \text {, } \\
\mathrm{p}=0.64 ;\end{array}$ & 96 weeks \\
\hline & $\begin{array}{l}\text { Vollmer et al., J } \\
\text { Neurol 2014, phase } \\
\text { III (BRAVO study) }\end{array}$ & $\begin{array}{l}\text { RRMS } \\
(n=1331)\end{array}$ & $\begin{array}{l}\text { Laquinimod } \\
\text { 0.6mg: } 66 \% \text {, } \\
\text { Placebo: } 61 \% \text {, } \\
\text { IFN-beta } 30 \\
\text { mcg IM: } 69 \% ; p \\
\text { (Laq vs. } \\
\text { placebo) }=0.21 ; \\
\text { p (IFN vs. } \\
\text { placebo) }=0.023\end{array}$ & 24 months \\
\hline & $\begin{array}{l}\text { Cohen et al., JAMA } \\
\text { Neurol 2015, phase } \\
\text { III (GATE study) }\end{array}$ & $\begin{array}{l}\text { RRMS } \\
(n=796)\end{array}$ & $\begin{array}{l}\text { Generic GA } \\
20 \mathrm{mg} / \mathrm{d} \text { vs. } \\
\text { brand GA } \\
20 \mathrm{mg} / \mathrm{d} \text { vs. } \\
\text { placebo: } 79.3 \% \\
\text { vs. } 73.9 \% \text { vs. } \\
73.8 \% \text { (ns) }\end{array}$ & 9 months \\
\hline & $\begin{array}{l}\text { Kappos et al., New } \\
\text { Engl J Med 2015, } \\
\text { phase III (DECIDE } \\
\text { study) }\end{array}$ & $\begin{array}{l}\text { RRMS } \\
(n=1841)\end{array}$ & $\begin{array}{l}\text { Daclizumab HYP } \\
150 \mathrm{mg} / 4 \text { weeks } \\
\text { vs. IFN beta-1a } \\
30 \mu \mathrm{m} / \text { week: } \\
67 \% \text { vs. } 51 \% \text {, } \\
\text { p }<0.05\end{array}$ & 144 weeks \\
\hline & $\begin{array}{l}\text { Lanzillo et al., Mult } \\
\text { Scler Journal 2015, } \\
\text { phase III (ARIANNA } \\
\text { study) }\end{array}$ & $\begin{array}{l}\text { RRMS } \\
(n=154)\end{array}$ & $\begin{array}{l}\text { IFN beta-1b } 8 \\
\text { MIU eod SC + } \\
\text { atorvastatin } \\
40 \mathrm{mg} \text { PO vs. } \\
\text { IFN beta- } 1 \mathrm{~b} \\
\text { MIU eod SC }+ \\
\text { placebo: } 69 \% \\
\text { vs. } 75 \% \text { (ns) }\end{array}$ & 24 months \\
\hline $\begin{array}{l}\text { Time to first } \\
\text { confirmed } \\
\text { relapse }\end{array}$ & $\begin{array}{l}\text { Johnson et al., } \\
\text { Neurology 1995, } \\
\text { phase III (The } \\
\text { Copolymer } 1 \\
\text { Multiple Sclerosis } \\
\text { Study) }\end{array}$ & $\begin{array}{l}\text { RRMS } \\
(n=251)\end{array}$ & $\begin{array}{l}\text { Median time: } \\
\text { Glatiramer } \\
\text { acetate } 20 \mathrm{mg} \\
\text { SC/day: } 287 \\
\text { days, vs. } \\
\text { placebo: } 198 \\
\text { days, } \mathrm{p}=0.097\end{array}$ & 24 months \\
\hline & $\begin{array}{l}\text { PRISMS study group } \\
\text { (Prevention of } \\
\text { Relapses and } \\
\text { Disability by } \\
\text { Interferon beta-1a } \\
\text { Subcutaneously in } \\
\text { Multiple Sclerosis) } \\
\text { Study Group, Lancet } \\
\text { 1998, phase III } \\
\text { (PRISMS study) }\end{array}$ & $\begin{array}{l}\text { RRMS } \\
(n=560)\end{array}$ & $\begin{array}{l}\text { Median time to } \\
\text { relapse: } \\
\text { delayed by } 3 \text { or } \\
5 \text { months, for } \\
\text { IFN beta-1a } \\
22 \text { mcg SC tiw or } \\
\text { IFN beta-1a } \\
44 \text { mcg SC tiw, } \\
\text { vs. placebo, } \\
\text { respectively } \\
\text { ( } p<0.05) \text {; }\end{array}$ & 24 months \\
\hline & Panitch et al., & RRMS & IFN beta-1a SC & 24 months \\
\hline
\end{tabular}




\begin{tabular}{|c|c|c|c|c|c|}
\hline & & $\begin{array}{l}\text { Neurology 2002; } \\
\text { Schwid et al., } \\
\text { Clinical Therapeutics } \\
\text { 2007, phase } 4- \\
\text { post- } \\
\text { commercialisation } \\
\text { (EVIDENCE study) }\end{array}$ & $(n=677)$ & $\begin{array}{l}\text { 44mcg tiw: } 13.5 \\
\text { mo.; IFN beta- } \\
\text { 1a IM } \\
\text { 30mcg/week: } \\
6.7 \text { mo.; HR } \\
(95 \% \text { CI) } 0.70 \\
(0.56 \text { to } 0.88) \text {, } \\
p=0.002\end{array}$ & $\begin{array}{l}\text { (0-12m: } \\
\text { comparative } \\
\text { phase; } 12- \\
24 \mathrm{~m} \text { : cross- } \\
\text { over phase) } \\
\text { (n) }\end{array}$ \\
\hline & & $\begin{array}{l}\text { O'Connor et al., } \\
\text { Lancet Neurol 2009, } \\
\text { phase III (BEYOND } \\
\text { study) }\end{array}$ & $\begin{array}{l}\text { RRMS } \\
(n=2244)\end{array}$ & $\begin{array}{l}\text { GA } 20 \mathrm{mg} \\
\text { SC/day at } 2 \\
\text { years FU: } 271 \\
\text { days ( } 25^{\text {th }} \\
\text { percentile); } \\
\text { IFN beta- } 1 \mathrm{~b} \\
250 \text { mcg SC EOD } \\
\text { at } 2 \text { years FU: } \\
283 \text { days ( } 25^{\text {th }} \\
\text { percentile); } \\
\text { IFN beta- } 1 \mathrm{~b} \\
500 \text { mcg SC EOD } \\
\text { at } 2 \text { years FU: } \\
348 \text { days ( } 25^{\text {th }} \\
\text { percentile), p } \\
\text { values (all } \\
\text { comparisons) > } \\
0.05\end{array}$ & 24 months \\
\hline & & $\begin{array}{l}\text { Kappos et al., NEJM } \\
\text { 2010, phase III } \\
\text { (FREEDOMS study) }\end{array}$ & $\begin{array}{l}\text { RRMS } \\
(n=1272)\end{array}$ & $\begin{array}{l}\text { Fingolimod } \\
0.5 \mathrm{mg} / \text { day vs. } \\
\text { placebo: } \mathrm{HR} \\
(95 \% \mathrm{Cl}) 0.48 \\
(0.39 \text { to } 0.61) \\
\mathrm{p}<0.001 \\
\text { Fingolimod } \\
1.25 \mathrm{mg} / \text { day vs. } \\
\text { placebo: } \mathrm{HR} \\
(95 \% \mathrm{Cl}) 0.38 \\
(0.30 \text { to } 0.48) \text {, } \\
\mathrm{p}<0.001\end{array}$ & 24 months \\
\hline & & $\begin{array}{l}\text { Giovannoni et al., } \\
\text { NEJM 2010, phase } \\
\text { III (CLARITY study) }\end{array}$ & $\begin{array}{l}\text { RRMS } \\
(n=1326)\end{array}$ & $\begin{array}{l}\text { Cladribine } \\
\text { 3.5mg/Kg vs. } \\
\text { placebo: } \mathrm{HR} \\
(95 \% \mathrm{Cl}) 0.44 \\
(0.34 \text { to } 0.58) \text {, } \\
\text { p<0.001 } \\
\text { Cladribine } \\
5.25 \mathrm{mg} / \mathrm{Kg} \text { vs. } \\
\text { placebo: } \mathrm{HR} \\
(95 \% \mathrm{Cl}) 0.46 \\
(0.36 \text { to } 0.60) \text {, } \\
\mathrm{p}<0.001\end{array}$ & 96 weeks \\
\hline & & $\begin{array}{l}\text { Sorensen et al., } \\
\text { Lancet Neurology } \\
2011, \text { phase } 4 \\
\text { (SIMCOMBIN study) }\end{array}$ & $\begin{array}{l}\text { RRMS } \\
(n=307)\end{array}$ & $\begin{array}{l}\text { IFN beta-1a } \\
30 \mathrm{mcg} \\
\text { IM/week + } \\
\text { simvastatin } \\
80 \mathrm{mg} / \text { day vs. } \\
\text { IFN beta-1a }\end{array}$ & $\begin{array}{l}12 \text { months } \\
\text { after last } \\
\text { patient was } \\
\text { included }\end{array}$ \\
\hline
\end{tabular}




\begin{tabular}{|c|c|c|c|c|c|}
\hline & & & & $\begin{array}{l}30 \mathrm{mcg} \\
\text { IM/week + } \\
\text { Placebo: HR } \\
\text { (95\% Cl) } 1.21 \\
(0.74 \text { to } 1.99) \\
\mathrm{p}=0.512\end{array}$ & \\
\hline & & $\begin{array}{l}\text { Fox et al., NEJM } \\
\text { 2012, phase III } \\
\text { (CONFIRM study) }\end{array}$ & $\begin{array}{l}\text { RRMS } \\
(n=1417)\end{array}$ & 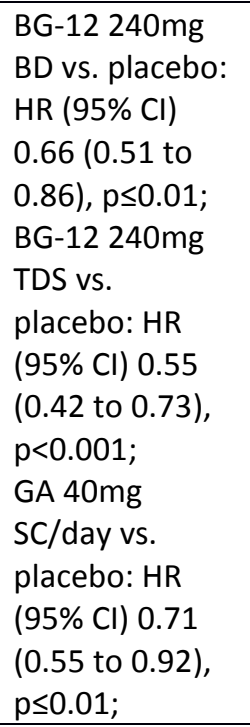 & 24 months \\
\hline & & $\begin{array}{l}\text { Gold et al., NEJM } \\
\text { 2012, phase III } \\
\text { (DEFINE study) }\end{array}$ & $\begin{array}{l}\text { RRMS } \\
(n=1234)\end{array}$ & $\begin{array}{l}\text { BG-12 240mg } \\
\text { BD vs. placebo: } \\
\text { HR }(95 \% \mathrm{Cl}) \\
0.51(0.40 \text { to } \\
0.66), p<0.001 ; \\
\text { BG-12 240mg } \\
\text { TDS vs. } \\
\text { placebo: HR } \\
\text { ( } 95 \% \text { Cl) } 0.50 \\
(0.39 \text { to } 0.65) \text {, } \\
\text { p<0.001; }\end{array}$ & 24 months \\
\hline & & $\begin{array}{l}\text { O'Connor et al., } \\
\text { NEJM 2011, phase } \\
\text { III (TEMSO study) }\end{array}$ & $\begin{array}{l}\text { Relapsing } \\
\text { MS ( } n=1088)\end{array}$ & $\begin{array}{l}\text { Teriflunomide } \\
7 \mathrm{mg} \mathrm{PO} / \text { day vs. } \\
\text { placebo: HR } \\
\text { (95\% Cl) } 0.76 \\
(0.61-0.94) \text {, } \\
\text { p=0.01; } \\
\text { Teriflunomide } \\
\text { 14mg PO/day } \\
\text { vs. placebo: HR } \\
\text { (95\% Cl) } 0.72 \\
(0.58-0.90) \\
\text { p=0.003; }\end{array}$ & 108 weeks \\
\hline & & $\begin{array}{l}\text { Khan et al., Ann } \\
\text { Neurol 2013, phase } \\
\text { III (GALA study) }\end{array}$ & $\begin{array}{l}\text { RRMS } \\
(n=1404)\end{array}$ & $\begin{array}{l}\text { GA 40mg sc tiw } \\
\text { vs. placebo: HR } \\
(95 \% \mathrm{Cl}) 0.606 \\
(0.493 \text { to } \\
0.744), \\
\text { p<0.0001 }\end{array}$ & 12 months \\
\hline & & $\begin{array}{l}\text { Lublin et al., Ann } \\
\text { Neurol 2013, phase } \\
\text { III (CombiRx study) }\end{array}$ & $\begin{array}{l}\text { RRMS } \\
(n=1008)\end{array}$ & $\begin{array}{l}\text { HRs not } \\
\text { specified, } \\
p=0.19\end{array}$ & $\begin{array}{l}36 \text { months } \\
\text { after last } \\
\text { patient was } \\
\text { included }\end{array}$ \\
\hline
\end{tabular}




\begin{tabular}{|c|c|c|c|c|c|}
\hline & & $\begin{array}{l}\text { Massacesi et al., } \\
\text { PLoS ONE 2014, } \\
\text { phase III }\end{array}$ & $\begin{array}{l}\text { RRMS } \\
(n=150)\end{array}$ & $\begin{array}{l}\text { Azathioprine } \\
\text { (target dose: } 3 \\
\mathrm{mg} / \mathrm{kg} / \mathrm{d} \text { ) vs. } \\
\text { IFN beta (1a or } \\
\text { 1b) (hazard } \\
\text { ratio [95\%Cl]): } \\
0.66(0.40- \\
1.10) \text { (ns) }\end{array}$ & 24 months \\
\hline & & $\begin{array}{l}\text { Mikol et al., Lancet } \\
\text { Neurol 2014, phase } \\
\text { III (REGARD study) }\end{array}$ & $\begin{array}{l}\text { RRMS } \\
(n=764)\end{array}$ & $\begin{array}{l}\text { IFN beta- } 1 \mathrm{a} \\
44 \mathrm{mcg} \mathrm{SC} \text { tiw } \\
\text { vs. glatiramer } \\
\text { acetate } 20 \mathrm{mg} \\
\mathrm{SC} / \text { day, HR } \\
(95 \% \mathrm{Cl}) 0.94 \\
(0.74-1.21) \\
\mathrm{p}=0.64 ;\end{array}$ & 96 weeks \\
\hline & $\begin{array}{l}\text { Time to failure, } \\
\text { defined as the } \\
\text { occurrence of } \\
\text { the first } \\
\text { confirmed } \\
\text { relapse or to } \\
\text { permanent } \\
\text { treatment } \\
\text { discontinuation } \\
\text { for any cause }\end{array}$ & $\begin{array}{l}\text { Vermersch et al., } \\
\text { MSJ 2014, phase III } \\
\text { (TENERE study) }\end{array}$ & $\begin{array}{l}\text { Relapsing } \\
\text { MS }(n=324)\end{array}$ & $\begin{array}{l}\text { Teriflunomide } \\
\text { 7mg vs. IFN } \beta- \\
\text { 1a: HR ( } 95 \% \mathrm{Cl}) \\
1.12 \text { (0.75 to } \\
\text { 1.67), } \mathrm{p}=0.52 ; \\
\text { Teriflunomide } \\
\text { 14mg vs. IFN } \beta- \\
\text { 1a: HR ( } 95 \% \mathrm{Cl}) \\
0.86(0.56 \text { to } \\
1.31), \mathrm{p}=0.60\end{array}$ & $\begin{array}{l}48 \text { weeks } \\
\text { after the } \\
\text { last patient } \\
\text { was } \\
\text { included }\end{array}$ \\
\hline & $\begin{array}{l}\text { Relapse risk } \\
\text { (assessed with } \\
\text { the Andersen- } \\
\text { Gill model for } \\
\text { time to } \\
\text { recurring } \\
\text { events) }\end{array}$ & $\begin{array}{l}\text { O'Connor et al., } \\
\text { Lancet Neurol 2009, } \\
\text { phase III (BEYOND } \\
\text { study) }\end{array}$ & $\begin{array}{l}\text { RRMS } \\
(n=2244)\end{array}$ & $\begin{array}{l}\text { IFN beta-1b } \\
500 \text { mcg SC eod } \\
\text { vs. IFN beta-1b } \\
250 \mathrm{mcg} \mathrm{SC} \text { eod: } \\
\mathrm{HR}(95 \% \mathrm{Cl}) \\
0 \cdot 94(0 \cdot 82- \\
1 \cdot 08), \mathrm{p}=0 \cdot 20 \text {; } \\
\text { IFN beta-1b } \\
500 \mathrm{mcg} \text { SC eod } \\
\text { vs. GA } 20 \mathrm{mg} \\
\text { SC/day: HR } \\
(95 \% \mathrm{Cl}) 1 \cdot 00 \\
(0 \cdot 83-1 \cdot 19), \\
\text { p=0.48; } \\
\text { IFN beta-1b } \\
250 \mathrm{mcg} \mathrm{SC} \text { eod } \\
\text { vs. GA } 20 \mathrm{mg} \\
\text { SC/day: HR } \\
(95 \% \mathrm{CI}) 1 \cdot 06 \\
(0 \cdot 89-1 \cdot 27) \text {, } \\
\text { p=0.74; }\end{array}$ & 24 months \\
\hline EDSS score & $\begin{array}{l}\text { Change in EDSS } \\
\text { score from } \\
\text { baseline to } \\
\text { follow-up (k) }\end{array}$ & $\begin{array}{l}\text { The IFNB Multiple } \\
\text { Sclerosis Study } \\
\text { Group, Neurology } \\
\text { 1993, phase III }\end{array}$ & $\begin{array}{l}\text { RRMS } \\
(n=372)\end{array}$ & $\begin{array}{l}\text { IFN beta-1b } 1.6 \\
\text { MIU, IFN beta- } \\
\text { 1b } 8 \text { MIU or } \\
\text { placebo: little } \\
\text { changes (not } \\
\text { significant - no } \\
\text { further details } \\
\text { given in the } \\
\text { abstract); }\end{array}$ & 24 months \\
\hline
\end{tabular}




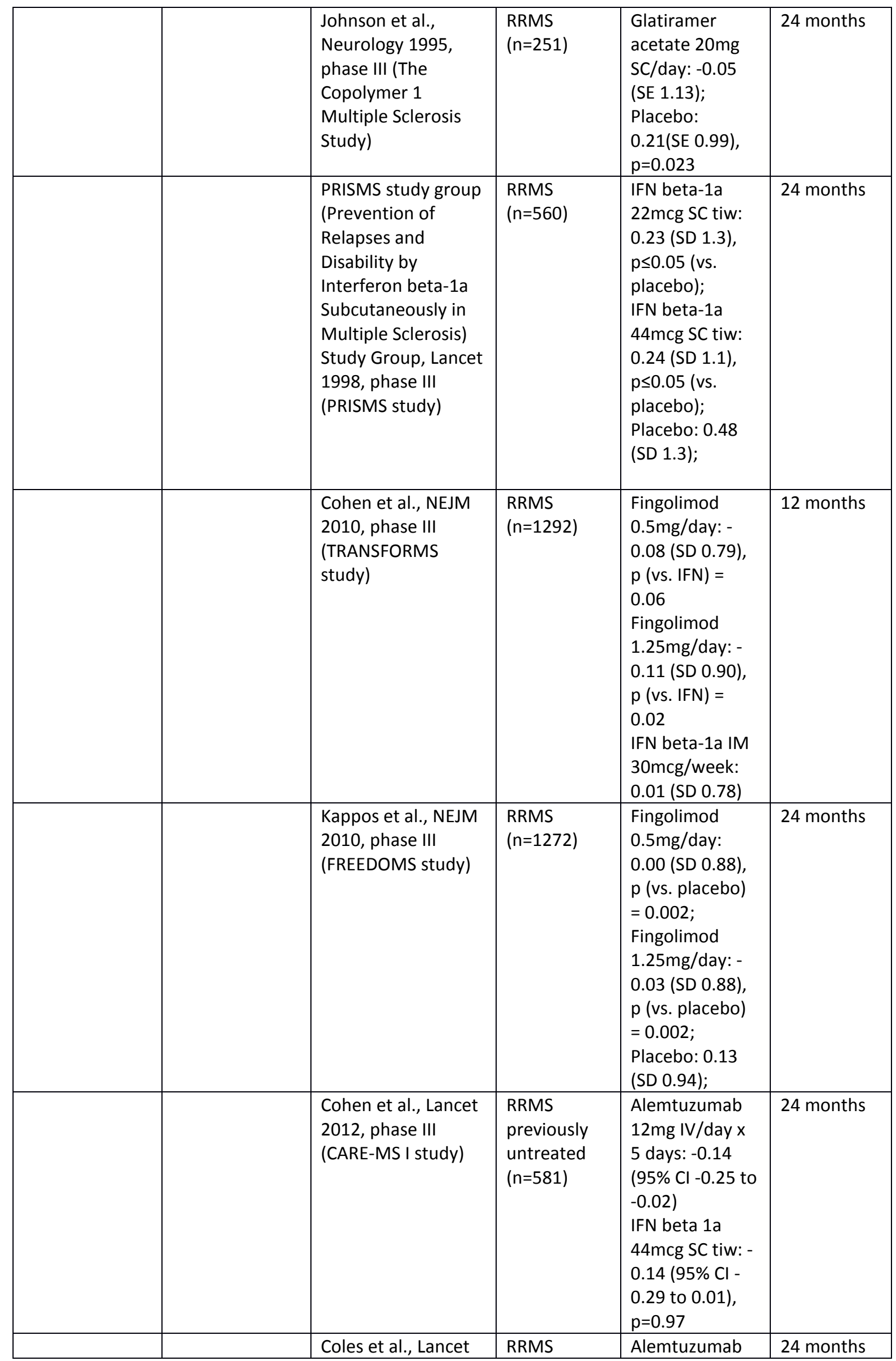




\begin{tabular}{|c|c|c|c|c|c|}
\hline & & $\begin{array}{l}\text { 2012, phase III } \\
\text { (CARE-MS II study) }\end{array}$ & $\begin{array}{l}\text { previously } \\
\text { treated } \\
(\mathrm{n}=840)\end{array}$ & $\begin{array}{l}12 \mathrm{mg} \text { IV/day } \mathrm{x} \\
5 \text { days: }-0.17 \\
(95 \% \mathrm{Cl}-0.29 \text { to } \\
-0.05) \text {; } \\
\text { IFN beta } 1 \mathrm{a} \\
44 \mathrm{mcg} \mathrm{SC} \text { tiw: } \\
0.24 \text { ( } 95 \% \mathrm{Cl} \\
0.07 \text { to } 0.41 \text { ), } \\
\text { p<0.0001 }\end{array}$ & \\
\hline & & $\begin{array}{l}\text { Calabresi et al., } \\
\text { Lancet Neurol 2014, } \\
\text { phase III } \\
\text { (FREEDOMS II study) }\end{array}$ & $\begin{array}{l}\text { RRMS } \\
(n=1083)\end{array}$ & $\begin{array}{l}\text { Fingolimod } \\
0.5 \mathrm{mg} \text { PO: } \\
0.046 \text { (SD: } \\
\text { 1.02); } \\
\text { Placebo: } 0.055 \\
\text { (SD: } 1.20) \\
\text { p=0.945 }\end{array}$ & 24 months \\
\hline & & $\begin{array}{l}\text { Confavreux et al., } \\
\text { Lancet Neurol 2014, } \\
\text { phase III (TOWER } \\
\text { study) }\end{array}$ & $\begin{array}{l}\text { RRMS } \\
(n=1169)\end{array}$ & $\begin{array}{l}\text { Teriflunomide } \\
\text { 7mg PO: } 0.04 \\
\text { (0.05), p (vs. } \\
\text { placebo) = } \\
\text { 0.4819; } \\
\text { Teriflunomide } \\
\text { 14mg PO: }-0.05 \\
\text { (0.05), p (vs. } \\
\text { placebo) = } \\
\text { 0.0429; } \\
\text { Placebo: } 0.09 \\
\text { (0.05); }\end{array}$ & $\begin{array}{l}48 \text { weeks } \\
\text { after the } \\
\text { last patient } \\
\text { was } \\
\text { included }\end{array}$ \\
\hline & & $\begin{array}{l}\text { Massacesi et al., } \\
\text { PLoS ONE 2014, } \\
\text { phase III }\end{array}$ & $\begin{array}{l}\text { RRMS } \\
(n=150)\end{array}$ & $\begin{array}{l}\text { Azathioprine } \\
\text { (target dose: } 3 \\
\mathrm{mg} / \mathrm{kg} / \text { day PO) } \\
\text { vs. IFN beta (1a } \\
\text { or } 1 \mathrm{~b} \mathrm{SC} \text { ) (mean } \\
\text { change } \\
[95 \% \mathrm{Cl}]): 20.08 \\
(20.3 \text { to } 0.16) \\
\text { vs. } 0.22(20.03 \\
\text { to } 0.47), \mathrm{p}=0.08\end{array}$ & 24 months \\
\hline & & $\begin{array}{l}\text { Cohen et al., JAMA } \\
\text { Neurol 2015, phase } \\
\text { III (GATE study) }\end{array}$ & $\begin{array}{l}\text { RRMS } \\
(n=796)\end{array}$ & $\begin{array}{l}\text { Generic GA } \\
\text { 20mg/d: (mean } \\
\text { change [range]) } \\
-0.11 \text { (-0.22 to } \\
0.00) ; \\
\text { Brand GA } \\
20 \mathrm{mg} / \mathrm{d}: \text { (mean } \\
\text { change [range]) } \\
-0.08 \text { (-0.19 to } \\
0.03 \text { ); } \\
\text { Placebo: (mean } \\
\text { change } \\
\text { [range]): }-0.02 \\
(-0.17 \text { to } 0.14 \text { ); } \\
\text { p-values (all } \\
\text { comparisons) } \\
>0.05\end{array}$ & 9 months \\
\hline & & Lanzillo et al., Mult & RRMS & IFN beta-1b 8 & 24 months \\
\hline
\end{tabular}




\begin{tabular}{|c|c|c|c|c|c|}
\hline & & $\begin{array}{l}\text { Scler Journal 2015, } \\
\text { phase III (ARIANNA } \\
\text { study) }\end{array}$ & $(n=154)$ & $\begin{array}{l}\text { MIU SC eod + } \\
\text { atorvastatin } \\
40 \mathrm{mg} / \mathrm{d}: 0.3 \text { vs. } \\
\text { IFN beta-1b } 8 \\
\text { MIU SC eod + } \\
\text { placebo: } 0.2 \text {, } \\
\text { p>0.05 }\end{array}$ & \\
\hline & $\begin{array}{l}\text { Time to 3- } \\
\text { month CDP (g) }\end{array}$ & $\begin{array}{l}\text { Jacobs et al., Ann } \\
\text { Neurol 1996, phase } \\
\text { III (MSCRG study) }\end{array}$ & $\begin{array}{l}\text { Relapsing } \\
\text { MS (n=301) }\end{array}$ & $\begin{array}{l}\text { IFN beta-1a } \\
30 \mathrm{mcg} \\
\text { IM/week vs. } \\
\text { placebo: HR <1, } \\
\mathrm{p}=0.02 \text { (v) }\end{array}$ & 104 weeks \\
\hline & & $\begin{array}{l}\text { PRISMS study group } \\
\text { (Prevention of } \\
\text { Relapses and } \\
\text { Disability by } \\
\text { Interferon beta-1a } \\
\text { Subcutaneously in } \\
\text { Multiple Sclerosis) } \\
\text { Study Group, Lancet } \\
\text { 1998, phase III } \\
\text { (PRISMS study) }\end{array}$ & $\begin{array}{l}\text { RRMS } \\
(n=560)\end{array}$ & $\begin{array}{l}\text { IFN beta-1a } \\
22 \text { mcg SC tiw: } \\
18.5 \text { months } \\
\text { (first quartile), } \\
\text { risk ratio ( } 95 \% \\
\mathrm{CI}) 0.68 \text { ( } 0.48 \text { to } \\
0.98 \text { ): p (vs. } \\
\text { placebo) <0.05; } \\
\text { IFN beta-1a } \\
44 \text { mcg SC tiw: } \\
21.3 \text { months } \\
\text { (first quartile), } \\
\text { risk ratio ( } 95 \% \\
\text { Cl) } 0.42 \text { (0.18 to } \\
0.99 \text { ), p (vs. } \\
\text { placebo) <0.05; } \\
\text { Placebo: } 11.9 \\
\text { months (first } \\
\text { quartile) (u) }\end{array}$ & 24 months \\
\hline & & $\begin{array}{l}\text { Noseworthy et al., } \\
\text { Neurology 2000, } \\
\text { phase III (linomide } \\
\text { study) }\end{array}$ & RMS (n=715) & $\begin{array}{l}\text { The study was } \\
\text { of insufficient } \\
\text { duration for } \\
\text { any of the } \\
\text { primary or } \\
\text { secondary } \\
\text { outcome } \\
\text { measures to } \\
\text { reach } \\
\text { significance }\end{array}$ & $\begin{array}{l}\text { Early } \\
\text { termination } \\
\text { for safety } \\
\text { issues } \\
\text { (initially } \\
\text { planned: } 36 \\
\text { months) }\end{array}$ \\
\hline & & $\begin{array}{l}\text { O'Connor et al., } \\
\text { Lancet Neurol 2009, } \\
\text { phase III (BEYOND } \\
\text { study) }\end{array}$ & $\begin{array}{l}\text { RRMS } \\
(n=2244)\end{array}$ & $\begin{array}{l}\text { IFN beta-1b } \\
500 \text { mcg SC EOD } \\
\text { at } 2 \text { years FU: } \\
190 \text { days }\left(10^{\text {th }}\right. \\
\text { percentile); } \\
\text { IFN beta-1b } \\
250 \text { mcg SC EOD } \\
\text { at } 2 \text { years FU: } \\
274 \text { days ( } 10^{\text {th }} \\
\text { percentile); } \\
\text { GA } 20 \mathrm{mg} \\
\text { SC/day at } 2 \\
\text { years FU: } 268 \\
\text { days (10 } \\
\text { percentile), } p\end{array}$ & 24 months \\
\hline
\end{tabular}




\begin{tabular}{|c|c|c|c|c|c|}
\hline & & & & $\begin{array}{l}\text { values (all } \\
\text { comparisons) > } \\
0.05\end{array}$ & \\
\hline & & $\begin{array}{l}\text { Kappos et al., NEJM } \\
\text { 2010, phase III } \\
\text { (FREEDOMS study) }\end{array}$ & $\begin{array}{l}\text { RRMS } \\
(n=1272)\end{array}$ & $\begin{array}{l}\text { Fingolimod } \\
0.5 \mathrm{mg} / \text { day vs. } \\
\text { placebo: } \mathrm{HR} \\
(95 \% \mathrm{Cl}) 0.70 \\
(0.52 \text { to } 0.96), \mathrm{p} \\
=0.02 \\
\text { Fingolimod } \\
1.25 \mathrm{mg} / \text { day vs. } \\
\text { placebo: } \mathrm{HR} \\
(95 \% \mathrm{Cl}) 0.68 \\
(0.50 \text { to } 0.93), \mathrm{p} \\
=0.02\end{array}$ & 24 months \\
\hline & & $\begin{array}{l}\text { Giovannoni et al., } \\
\text { NEJM 2010, phase } \\
\text { III (CLARITY study) }\end{array}$ & $\begin{array}{l}\text { RRMS } \\
(n=1326)\end{array}$ & $\begin{array}{l}\text { Cladribine } \\
3.5 \mathrm{mg} / \mathrm{Kg} \text { vs. } \\
\text { placebo: } \mathrm{HR} \\
(95 \% \mathrm{Cl}) 0.67 \\
(0.48 \text { to } 0.93), \\
\mathrm{p}<0.001 \\
\text { Cladribine } \\
5.25 \mathrm{mg} / \mathrm{Kg} \text { vs. } \\
\text { placebo: } \mathrm{HR} \\
(95 \% \mathrm{Cl}) 0.69 \\
(0.49 \text { to } 0.96) \\
p<0.001\end{array}$ & 96 weeks \\
\hline & & $\begin{array}{l}\text { O'Connor et al., } \\
\text { NEJM 2011, phase } \\
\text { III (TEMSO study) }\end{array}$ & $\begin{array}{l}\text { Relapsing } \\
\text { MS ( } n=1088)\end{array}$ & $\begin{array}{l}\text { Teriflunomide } \\
7 \mathrm{mg} \text { PO/day vs. } \\
\text { placebo: HR } \\
(95 \% \mathrm{Cl}) 0.76 \\
(0.56-1.05) \\
\mathrm{p}=0.08 \\
\text { Teriflunomide } \\
\text { 14mg PO/day } \\
\text { vs. placebo: HR } \\
(95 \% \mathrm{Cl}) 0.70 \\
(0.51-0.97) ; \\
p=0.03\end{array}$ & 108 weeks \\
\hline & & $\begin{array}{l}\text { Sorensen et al., } \\
\text { Lancet Neurology } \\
2011, \text { phase } 4 \\
\text { (SIMCOMBIN study) }\end{array}$ & $\begin{array}{l}\text { RRMS } \\
(n=307)\end{array}$ & $\begin{array}{l}\text { IFN beta-1a } \\
30 \mathrm{mcg} \\
\text { IM/week + } \\
\text { simvastatin } \\
80 \mathrm{mg} / \text { day vs. } \\
\text { mThe } \\
\text { IFN beta-1a } \\
30 \mathrm{mcg} \\
\text { IM/week + } \\
\text { Placebo: HR } \\
(95 \% \mathrm{Cl}) 1.01 \\
(0.63 \text { to } 1.64) \text {, } \\
\mathrm{p}=0.953\end{array}$ & $\begin{array}{l}12 \text { months } \\
\text { after last } \\
\text { patient was } \\
\text { included }\end{array}$ \\
\hline & & $\begin{array}{l}\text { Comi et al., NEJM } \\
\text { 2012, phase III } \\
\text { (ALLEGRO study) }\end{array}$ & $\begin{array}{l}\text { RRMS } \\
(n=1106)\end{array}$ & $\begin{array}{l}\text { Laquinimod } \\
\text { 0.6mg OD vs. } \\
\text { placebo: HR } \\
(95 \% \mathrm{Cl}) 0.64\end{array}$ & 24 months \\
\hline
\end{tabular}




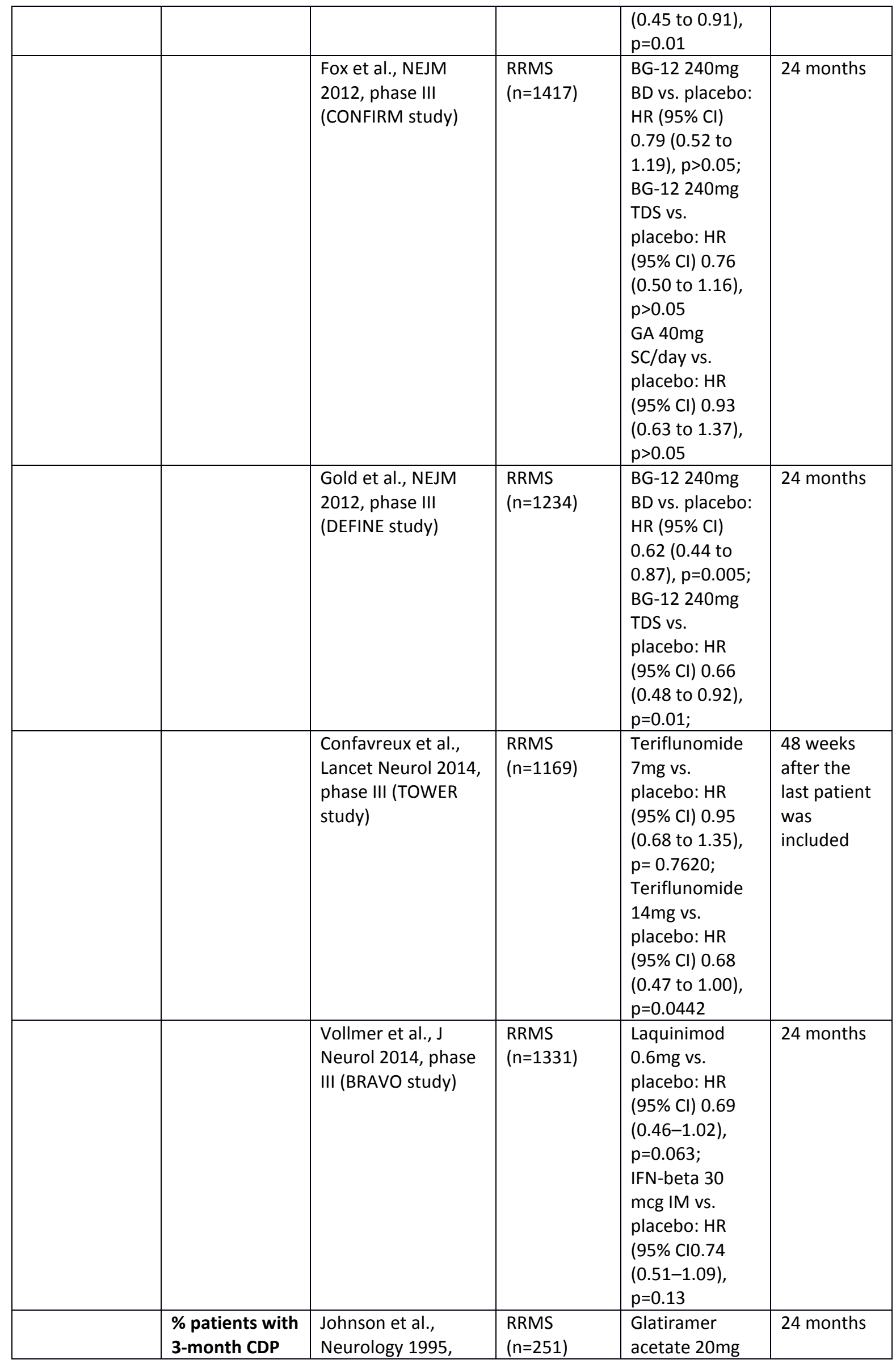




\begin{tabular}{|c|c|c|c|c|c|}
\hline & & $\begin{array}{l}\text { phase III (The } \\
\text { Copolymer } 1 \\
\text { Multiple Sclerosis } \\
\text { Study) }\end{array}$ & & $\begin{array}{l}\text { SC/day: } 20.8 \% ; \\
\text { Placebo: } 28.8 \% \text {, } \\
p=0.037\end{array}$ & \\
\hline & & $\begin{array}{l}\text { Jacobs et al., Ann } \\
\text { Neurol 1996, phase } \\
\text { III (MSCRG study) }\end{array}$ & $\begin{array}{l}\text { Relapsing } \\
\text { MS }(n=301)\end{array}$ & $\begin{array}{l}\text { IFN beta-1a } \\
30 \text { mcg } \\
\text { IM/week: } \\
21.9 \% ; \\
\text { Placebo: } 34.9 \% \text {, } \\
\text { p<0.05 (v) }\end{array}$ & 104 weeks \\
\hline & & $\begin{array}{l}\text { Noseworthy et al., } \\
\text { Neurology 2000, } \\
\text { phase III (linomide } \\
\text { study) }\end{array}$ & RMS $(n=715)$ & $\begin{array}{l}\text { The study was } \\
\text { of insufficient } \\
\text { duration for } \\
\text { any of the } \\
\text { primary or } \\
\text { secondary } \\
\text { outcome } \\
\text { measures to } \\
\text { reach } \\
\text { significance }\end{array}$ & $\begin{array}{l}\text { Early } \\
\text { termination } \\
\text { for safety } \\
\text { issues } \\
\text { (initially } \\
\text { planned: } 36 \\
\text { months) }\end{array}$ \\
\hline & & $\begin{array}{l}\text { Polman et al., NEJM } \\
\text { 2006, phase III } \\
\text { (AFFIRM study) }\end{array}$ & $\begin{array}{l}\text { RRMS } \\
(n=627)\end{array}$ & $\begin{array}{l}\text { Natalizumab } \\
300 \mathrm{mg} / 4 \\
\text { weeks: } 17 \%, \mathrm{p} \\
\text { (vs. placebo) } \\
<0.001 ; \\
\text { Placebo: } 29 \%\end{array}$ & 24 months \\
\hline & & $\begin{array}{l}\text { Rudick et al., NEJM } \\
\text { 2006, phase III } \\
\text { (SENTINEL study) }\end{array}$ & $\begin{array}{l}\text { RRMS } \\
(n=1171)\end{array}$ & $\begin{array}{l}\text { Natalizumab } \\
300 \mathrm{mg} / 4 \text { weeks } \\
\text { + IFN beta-1a } \\
\text { IM } \\
30 \mathrm{mcg} / \text { week: } \\
23 \% \text {; } \\
\text { IFN beta-1a IM } \\
30 \mathrm{mcg} / \text { week: } \\
29 \%, p=0.02\end{array}$ & 24 months \\
\hline & & $\begin{array}{l}\text { O'Connor et al., } \\
\text { Lancet Neurol 2009, } \\
\text { phase III (BEYOND } \\
\text { study) }\end{array}$ & $\begin{array}{l}\text { RRMS } \\
(n=2244)\end{array}$ & $\begin{array}{l}\text { IFN beta-1b } \\
500 \text { mcg SC EOD } \\
\text { at } 2 \text { years FU: } \\
22 \% \\
\text { IFN beta- } 1 \mathrm{~b} \\
250 \text { mcg SC EOD } \\
\text { at } 2 \text { years FU: } \\
21 \% \text {; } \\
\text { GA } 20 \mathrm{mg} \\
\text { SC/day at } 2 \\
\text { years FU: } 20 \% \text {, } \\
\text { p values (all } \\
\text { comparisons) > } \\
0.05\end{array}$ & 24 months \\
\hline & & $\begin{array}{l}\text { O'Connor et al., } \\
\text { NEJM 2011, phase } \\
\text { III (TEMSO study) }\end{array}$ & $\begin{array}{l}\text { Relapsing } \\
\text { MS ( } n=1088)\end{array}$ & $\begin{array}{l}\text { Teriflunomide } \\
\text { 7mg PO/day: } \\
21.7 \text { (17.1- } \\
\text { 26.3), p (vs. } \\
\text { placebo) = 0.08; } \\
\text { Teriflunomide } \\
\text { 14mg PO/day: }\end{array}$ & 108 weeks \\
\hline
\end{tabular}




\begin{tabular}{|c|c|c|c|c|c|}
\hline & & & & $\begin{array}{l}20.2(15.6- \\
24.7), p \text { (vs. } \\
\text { placebo) = } 0.03 ; \\
\text { Placebo: } 27.3 \\
(22.3-32.3)\end{array}$ & \\
\hline & & $\begin{array}{l}\text { Sorensen et al., } \\
\text { Lancet Neurology } \\
2011, \text { phase } 4 \\
\text { (SIMCOMBIN study) }\end{array}$ & $\begin{array}{l}\text { RRMS } \\
(n=307)\end{array}$ & $\begin{array}{l}\text { IFN beta-1a } \\
30 \mathrm{mcg} \\
\text { IM/week + } \\
\text { Placebo: } 24 \% \text {; } \\
\text { IFN beta-1a } \\
30 \mathrm{mcg} \\
\text { IM/week + } \\
\text { simvastatin } \\
80 \mathrm{mg} / \text { day: } \\
28 \%, p=0.953\end{array}$ & $\begin{array}{l}12 \text { months } \\
\text { after last } \\
\text { patient was } \\
\text { included }\end{array}$ \\
\hline & & $\begin{array}{l}\text { Comi et al., NEJM } \\
\text { 2012, phase III } \\
\text { (ALLEGRO study) }\end{array}$ & $\begin{array}{l}\text { RRMS } \\
(n=1106)\end{array}$ & $\begin{array}{l}\text { Laquinimod } \\
0.6 \mathrm{mg} \text { OD: } \\
11.1 \%, \mathrm{p} \text { (vs. } \\
\text { placebo) }=0.01 ; \\
\text { Placebo: } 15.7 \%\end{array}$ & 24 months \\
\hline & & $\begin{array}{l}\text { Fox et al., NEJM } \\
\text { 2012, phase III } \\
\text { (CONFIRM study) }\end{array}$ & $\begin{array}{l}\text { RRMS } \\
(n=1417)\end{array}$ & $\begin{array}{l}\text { BG-12 240mg } \\
\text { BD: } 13 \%, \mathrm{p} \text { (vs. } \\
\text { placebo) >0.05; } \\
\text { BG-12 240mg } \\
\text { TDS: 13\%, p (vs. } \\
\text { placebo) >0.05; } \\
\text { GA 40mg } \\
\text { SC/day: 16\%, p } \\
\text { (vs. placebo) } \\
>0.05 ; \\
\text { Placebo: } 17 \%\end{array}$ & 24 months \\
\hline & & $\begin{array}{l}\text { Gold et al., NEJM } \\
\text { 2012, phase III } \\
\text { (DEFINE study) }\end{array}$ & $\begin{array}{l}\text { RRMS } \\
(n=1234)\end{array}$ & $\begin{array}{l}\text { BG-12 240mg } \\
\text { BD: 16\%, p (vs. } \\
\text { placebo) = } \\
0.005 ; \\
\text { BG-12 240mg } \\
\text { TDS: } 18 \%, \mathrm{p} \text { (vs. } \\
\text { placebo) = } 0.01 ; \\
\text { Placebo: } 27 \%\end{array}$ & 24 months \\
\hline & & $\begin{array}{l}\text { Calabresi et al. } \\
\text { Lancet Neurol 2014, } \\
\text { phase III (ADVANCE } \\
\text { study) }\end{array}$ & $\begin{array}{l}\text { RRMS } \\
(n=1516)\end{array}$ & 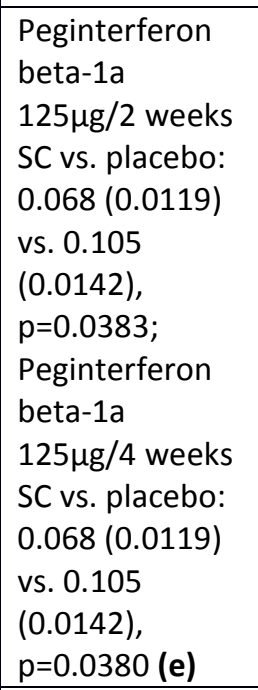 & $\begin{array}{l}24 \text { months } \\
\text { (but } \\
\text { primary } \\
\text { endpoint: } \\
48 \text { weeks, } \\
\text { which is the } \\
\text { placebo- } \\
\text { controlled } \\
\text { phase) }\end{array}$ \\
\hline & & Massacesi et al., & RRMS & Azathioprine & 24 months \\
\hline
\end{tabular}




\begin{tabular}{|c|c|c|c|c|c|}
\hline & & $\begin{array}{l}\text { PLoS ONE 2014, } \\
\text { phase III }\end{array}$ & $(n=150)$ & $\begin{array}{l}\text { (target dose: } 3 \\
\mathrm{mg} / \mathrm{kg} / \mathrm{d} \text { ) vs. } \\
\text { IFN beta (1a or } \\
1 \mathrm{~b} \mathrm{SC}): 1.8 \% \text { vs. } \\
8 \%, p=0.19\end{array}$ & \\
\hline & & $\begin{array}{l}\text { Vollmer et al., J } \\
\text { Neurol 2014, phase } \\
\text { III (BRAVO study) }\end{array}$ & $\begin{array}{l}\text { RRMS } \\
(n=1331)\end{array}$ & $\begin{array}{l}\text { Laquinimod } \\
0.6 \mathrm{mg} \text { : } 10 \% ; \\
\text { IFN-beta } 30 \\
\text { mcg IM: } 11 \% ; \\
\text { Placebo: } 13 \% ; \mathrm{p} \\
\text { (Laq vs. } \\
\text { placebo)=0.063; } \\
\text { p (IFN vs. } \\
\text { placebo) }=0.13\end{array}$ & 24 months \\
\hline & & $\begin{array}{l}\text { Kappos et al., New } \\
\text { Engl J Med 2015, } \\
\text { phase III (DECIDE } \\
\text { study) }\end{array}$ & $\begin{array}{l}\text { RRMS } \\
(n=1841)\end{array}$ & $\begin{array}{l}\text { Daclizumab HYP } \\
150 \mathrm{mg} / 4 \text { weeks } \\
\text { vs. IFN beta-1a } \\
30 \mathrm{mcg} / \text { week: } \\
16 \% \text { vs. } 20 \% \\
(p=0.16)\end{array}$ & 144 weeks \\
\hline & $\begin{array}{l}\text { Time to 6- } \\
\text { month CDP }\end{array}$ & $\begin{array}{l}\text { Kappos et al., NEJM } \\
2010, \text { phase III } \\
\text { (FREEDOMS study) }\end{array}$ & $\begin{array}{l}\text { RRMS } \\
(n=1272)\end{array}$ & $\begin{array}{l}\text { Fingolimod } \\
0.5 \mathrm{mg} / \text { day vs. } \\
\text { placebo: HR } \\
(95 \% \mathrm{Cl}) 0.63 \\
(0.440 .90), \mathrm{p}= \\
0.01 \\
\text { Fingolimod } \\
1.25 \mathrm{mg} / \text { day vs. } \\
\text { placebo: HR } \\
(95 \% \mathrm{Cl}) 0.60 \\
(0.41 \text { to } 0.86), \mathrm{p} \\
=0.006\end{array}$ & 24 months \\
\hline & & $\begin{array}{l}\text { Sorensen et al., } \\
\text { Lancet Neurology } \\
2011 \text {, phase } 4 \\
\text { (SIMCOMBIN study) }\end{array}$ & $\begin{array}{l}\text { RRMS } \\
(n=307)\end{array}$ & $\begin{array}{l}\text { IFN beta-1a } \\
30 \mathrm{mcg} \\
\text { IM/week + } \\
\text { simvastatin } \\
80 \mathrm{mg} / \text { day vs. } \\
\text { IFN beta-1a } \\
30 \mathrm{mcg} \\
\text { IM/week + } \\
\text { Placebo: HR } \\
0.991, p=0.986\end{array}$ & $\begin{array}{l}12 \text { months } \\
\text { after last } \\
\text { patient was } \\
\text { included }\end{array}$ \\
\hline & & $\begin{array}{l}\text { Cohen et al., Lancet } \\
\text { 2012, phase III } \\
\text { (CARE-MS I study) }\end{array}$ & $\begin{array}{l}\text { RRMS } \\
\text { previously } \\
\text { untreated } \\
(n=581)\end{array}$ & $\begin{array}{l}\text { IFN beta } 1 \mathrm{a} \\
44 \mathrm{mcg} \text { SC tiw } \\
\text { vs. } \\
\text { Alemtuzumab } \\
12 \mathrm{mg} \mathrm{IV/day} \mathrm{x} \\
5 \text { days: HR ( } 95 \% \\
\mathrm{Cl}) 0.70(0.40 \text { to } \\
1.23), \mathrm{p}=0.22\end{array}$ & 24 months \\
\hline & & $\begin{array}{l}\text { Coles et al., Lancet } \\
\text { 2012, phase III } \\
\text { (CARE-MS II study) }\end{array}$ & $\begin{array}{l}\text { RRMS } \\
\text { previously } \\
\text { treated } \\
(\mathrm{n}=840)\end{array}$ & $\begin{array}{l}\text { IFN beta } 1 \mathrm{a} \\
44 \mathrm{mcg} \text { SC tiw } \\
\text { vs. } \\
\text { Alemtuzumab } \\
12 \mathrm{mg} \text { IV/day x } \\
5 \text { days: HR }(95 \%\end{array}$ & 24 months \\
\hline
\end{tabular}




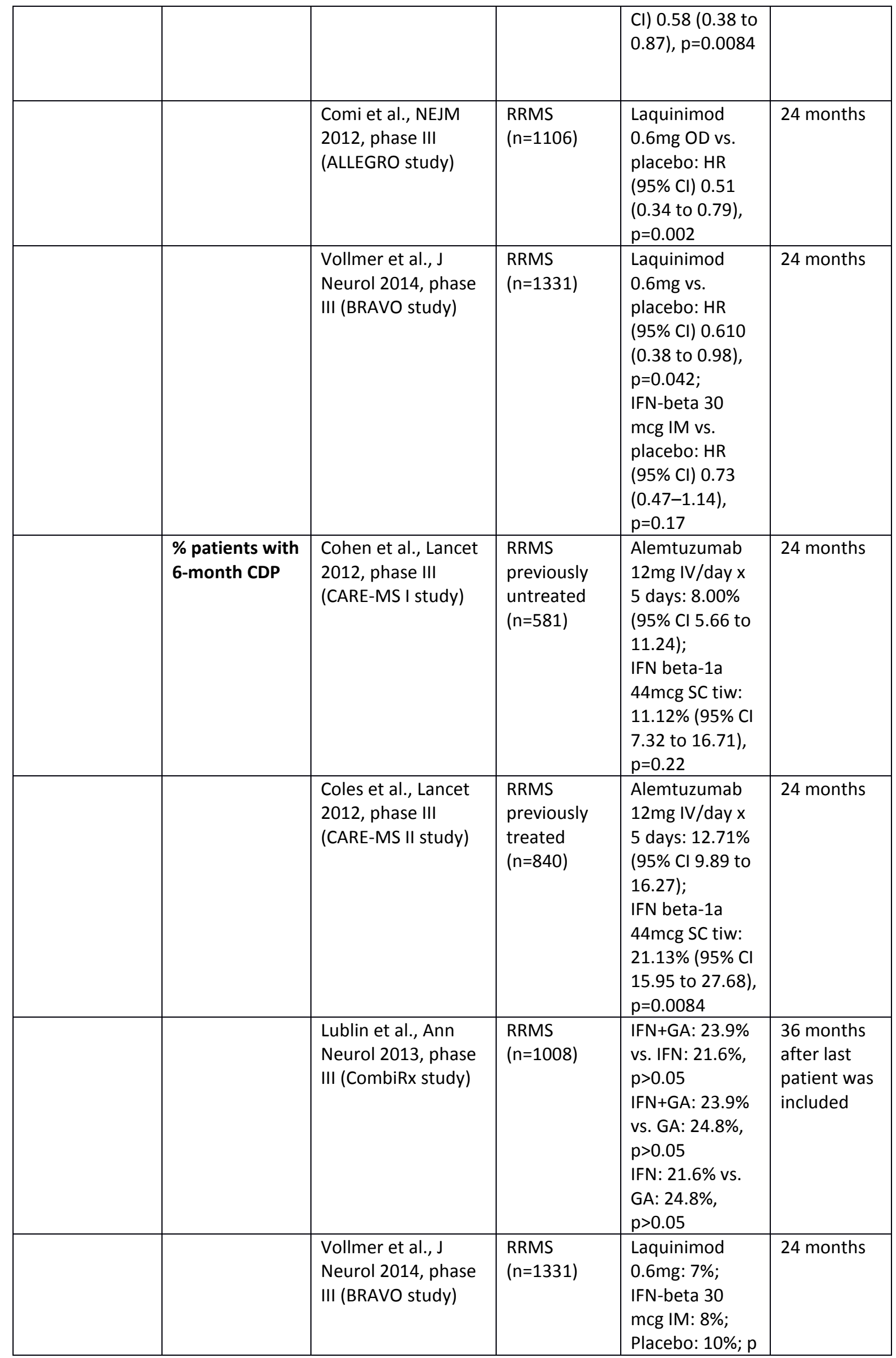




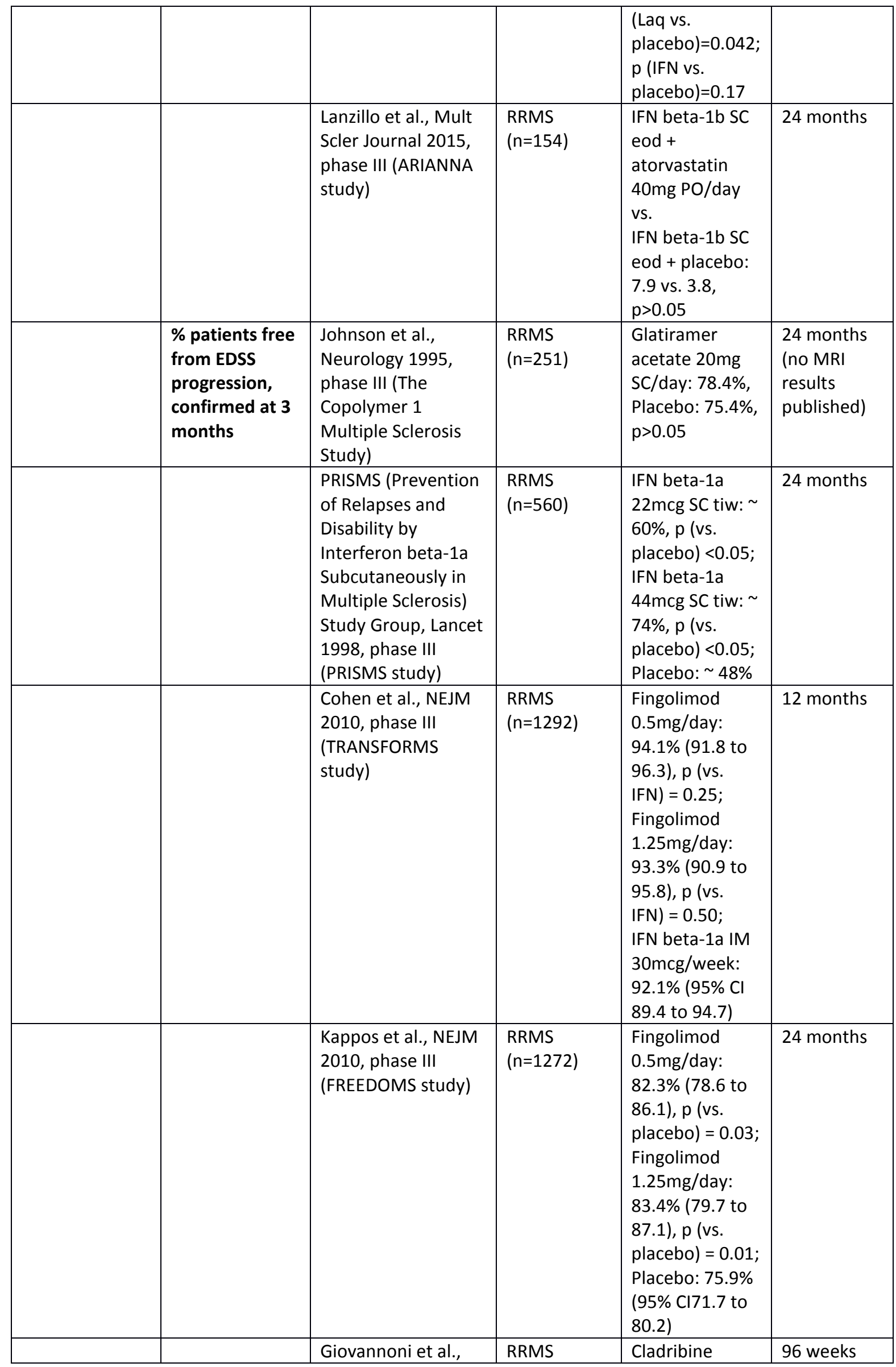




\begin{tabular}{|c|c|c|c|c|c|}
\hline & & $\begin{array}{l}\text { NEJM 2010, phase } \\
\text { III (CLARITY study) }\end{array}$ & $(n=1326)$ & $\begin{array}{l}\text { 3.5mg/Kg: } \\
85.7 \%, \mathrm{p} \text { (vs. } \\
\text { placebo) =0.02; } \\
\text { Cladribine } \\
5.25 \mathrm{mg} / \mathrm{Kg}: \\
84.9 \%, \mathrm{p} \text { (vs. } \\
\text { placebo) }=0.03 \\
\text { Placebo: } 79.4 \%\end{array}$ & \\
\hline & & $\begin{array}{l}\text { Calabresi et al., } \\
\text { Lancet Neurol 2014, } \\
\text { phase III } \\
\text { (FREEDOMS II study) }\end{array}$ & $\begin{array}{l}\text { RRMS } \\
(n=1083)\end{array}$ & $\begin{array}{l}\text { Fingolimod } \\
0.5 \mathrm{mg}: 74.7 \% \\
\text { (69.9 to } 79.5) ; \\
\text { Placebo: } 71.0 \% \\
\text { (65.9 to } 76.1) \\
p=0.320\end{array}$ & 24 months \\
\hline & & $\begin{array}{l}\text { Confavreux et al., } \\
\text { Lancet Neurol 2014, } \\
\text { phase III (TOWER } \\
\text { study) }\end{array}$ & $\begin{array}{l}\text { RRMS } \\
(n=1169)\end{array}$ & $\begin{array}{l}\text { Teriflunomide } \\
7 \mathrm{mg}: 78.9 \% \\
\text { ( } 73.9 \text { to } 83.9 \text { ), } \\
\mathrm{p}=0 \cdot 7620 ; \\
\text { Teriflunomide } \\
\text { 14mg: } 84.2 \% \\
\text { (79.6 to } 88.8 \text { ), } \\
p=0.0442 ; \\
\text { Placebo: } 80.3 \% \\
\text { ( } 75.9 \text { to } 84.8 \text { ) }\end{array}$ & $\begin{array}{l}48 \text { weeks } \\
\text { after the } \\
\text { last patient } \\
\text { was } \\
\text { included }\end{array}$ \\
\hline & $\begin{array}{l}\% \text { patients free } \\
\text { of EDSS } \\
\text { progression, } \\
\text { confirmed at } 6 \\
\text { months }\end{array}$ & $\begin{array}{l}\text { Kappos et al., NEJM } \\
\text { 2010, phase III } \\
\text { (FREEDOMS study) }\end{array}$ & $\begin{array}{l}\text { RRMS } \\
(n=1272)\end{array}$ & $\begin{array}{l}\text { Fingolimod } \\
0.5 \mathrm{mg} / \text { day: } \\
87.5 \% \text { ( } 84.7 \text { to } \\
90.7), \mathrm{p} \text { (vs. } \\
\text { placebo) = 0.01; } \\
\text { Fingolimod } \\
\text { 1.25mg/day: } \\
88.5 \% \text { ( } 85.3 \text { to } \\
91.6), \mathrm{p} \text { (vs. } \\
\text { placebo) = } \\
0.004 ; \\
\text { Placebo: } 81.0 \% \\
\text { (95\% Cl } 77.1 \text { to } \\
84.9 \text { ) }\end{array}$ & 24 months \\
\hline & & $\begin{array}{l}\text { Calabresi et al., } \\
\text { Lancet Neurol 2014, } \\
\text { phase III } \\
\text { (FREEDOMS II study) }\end{array}$ & $\begin{array}{l}\text { RRMS } \\
(n=1083)\end{array}$ & $\begin{array}{l}\text { Fingolimod } \\
0.5 \mathrm{mg}: 86.2 \% \\
\text { ( } 82.3 \text { to } 90.0) ; \\
\text { Placebo: } 82.2 \% \\
\text { ( } 77.9 \text { to } 86.4 \text { ), } \\
p=0.101\end{array}$ & 24 months \\
\hline & & $\begin{array}{l}\text { Mikol et al., Lancet } \\
\text { Neurol 2014, phase } \\
\text { III (REGARD study) }\end{array}$ & $\begin{array}{l}\text { RRMS } \\
(n=764)\end{array}$ & $\begin{array}{l}\text { IFN beta-1a } \\
44 \mathrm{mcg} \text { SC tiw: } \\
11.7 \% \text {; } \\
\text { Glatiramer } \\
\text { acetate } 20 \mathrm{mg} \\
\text { SC/day: } 8.7 \% \text {, } \\
p=0.117\end{array}$ & 96 weeks \\
\hline & $\begin{array}{l}\text { \% patients with } \\
\text { improvement } \\
\text { of EDSS after } \\
24 \text { months }\end{array}$ & $\begin{array}{l}\text { Johnson et al., } \\
\text { Neurology 1995, } \\
\text { phase III (The } \\
\text { Copolymer } 1 \\
\text { Multiple Sclerosis }\end{array}$ & $\begin{array}{l}\text { RRMS } \\
(n=251)\end{array}$ & $\begin{array}{l}\text { Glatiramer } \\
\text { acetate } 20 \mathrm{mg} \\
\text { SC/day: } 24.8 \% \text {; } \\
\text { Placebo: } 15.2 \% \text {, } \\
p=0.037\end{array}$ & 24 months \\
\hline
\end{tabular}




\begin{tabular}{|c|c|c|c|c|c|}
\hline & & Study) & & & \\
\hline & $\begin{array}{l}\text { \% patients with } \\
\text { sustained EDSS } \\
\text { reduction for } 6 \\
\text { months }\end{array}$ & $\begin{array}{l}\text { Coles et al., Lancet } \\
\text { 2012, phase III } \\
\text { (CARE-MS II study) }\end{array}$ & $\begin{array}{l}\text { RRMS } \\
\text { previously } \\
\text { treated } \\
(\mathrm{n}=840)\end{array}$ & $\begin{array}{l}\text { Alemtuzumab } \\
12 \mathrm{mg} \text { IV/day x } \\
5 \text { days: } 28.82 \% \\
\text { ( } 95 \% \mathrm{Cl} 24.18 \\
\text { to } 34.13 \text { ); } \\
\text { IFN beta } 1 \mathrm{a} \\
44 \mathrm{mcg} \text { SC tiw: } \\
12.93 \% \text { ( } 95 \% \mathrm{Cl} \\
8.34 \text { to } 19.77) \text {, } \\
\mathrm{p}=0.0002\end{array}$ & 24 months \\
\hline \multirow[t]{5}{*}{ MSFC } & Score at FU & $\begin{array}{l}\text { Comi et al., NEJM } \\
\text { 2012, phase III } \\
\text { (ALLEGRO study) }\end{array}$ & $\begin{array}{l}\text { RRMS } \\
(n=1106)\end{array}$ & $\begin{array}{l}\text { Laquinimod } \\
0.6 \mathrm{mg} \text { PO/day: } \\
0.04 \text { (-0.02 to } \\
0.09) ; \\
\text { Placebo: } 0.06 \\
\text { (0.00 to } 0.11) \\
p=0.59 \text { (j) }\end{array}$ & 24 months \\
\hline & $\begin{array}{l}\text { Change in } \\
\text { MSFC z-score } \\
\text { from baseline } \\
\text { to follow-up (f) } \\
\text { (k) }\end{array}$ & $\begin{array}{l}\text { Cohen et al., NEJM } \\
\text { 2010, phase III } \\
\text { (TRANSFORMS } \\
\text { study) }\end{array}$ & $\begin{array}{l}\text { RRMS } \\
(n=1292)\end{array}$ & $\begin{array}{l}\text { Fingolimod } \\
0.5 \mathrm{mg} / \text { day: } \\
0.04 \text { (SD 0.42), } \\
\text { p (vs. IFN) = } \\
0.02 ; \\
\text { Fingolimod } \\
1.25 \mathrm{mg} / \text { day: } \\
0.08 \text { (SD 0.46), } \\
\text { p (vs. IFN) } \\
<0.001 ; \\
\text { IFN beta-1a IM } \\
\text { 30mcg/week: - } \\
0.03 \text { (SD 0.48) }\end{array}$ & 12 months \\
\hline & & $\begin{array}{l}\text { Kappos et al., NEJM } \\
\text { 2010, phase III } \\
\text { (FREEDOMS study) }\end{array}$ & $\begin{array}{l}\text { RRMS } \\
(n=1272)\end{array}$ & $\begin{array}{l}\text { Fingolimod } \\
0.5 \mathrm{mg} / \text { day: } \\
0.03 \text { (SD 0.39), } \\
\text { p (vs. placebo) } \\
=0.01 ; \\
\text { Fingolimod } \\
1.25 \mathrm{mg} / \text { day: } \\
0.01 \text { (SD 0.40), } \\
\text { p (vs. placebo) } \\
=0.02 ; \\
\text { Placebo: }-0.06 \\
\text { (SD 0.57) }\end{array}$ & 24 months \\
\hline & & $\begin{array}{l}\text { Cohen et al., Lancet } \\
\text { 2012, phase III } \\
\text { (CARE-MS I study) }\end{array}$ & $\begin{array}{l}\text { RRMS } \\
\text { previously } \\
\text { untreated } \\
(n=581)\end{array}$ & $\begin{array}{l}\text { Alemtuzumab } \\
12 \mathrm{mg} \text { IV/day x } \\
5 \text { days: } 0 \cdot 15 \text { (SD } \\
0 \cdot 52 \text { ); } \\
\text { IFN beta } 1 \mathrm{a} \\
44 \mathrm{mcg} \text { SC tiw: } \\
0.07 \text { (SD } 0.45 \text { ), } \\
\mathrm{p}=0.01\end{array}$ & 24 months \\
\hline & & $\begin{array}{l}\text { Coles et al., Lancet } \\
\text { 2012, phase III } \\
\text { (CARE-MS II study) }\end{array}$ & $\begin{array}{l}\text { RRMS } \\
\text { previously } \\
\text { treated } \\
(\mathrm{n}=840)\end{array}$ & $\begin{array}{l}\text { Alemtuzumab } \\
12 \mathrm{mg} \text { IV/day x } \\
5 \text { days: } 0.08 \\
(0.04 \text { to } 0.12) ; \\
\text { IFN beta } 1 \mathrm{a}\end{array}$ & 24 months \\
\hline
\end{tabular}




\begin{tabular}{|c|c|c|c|c|c|}
\hline & & & & $\begin{array}{l}44 m c g \text { SC tiw: - } \\
0.04(95 \% \mathrm{Cl}- \\
0.10 \text { to } 0.02) \\
p=0.002\end{array}$ & \\
\hline & & $\begin{array}{l}\text { Lublin et al., Ann } \\
\text { Neurol 2013, phase } \\
\text { III (CombiRx study) }\end{array}$ & $\begin{array}{l}\text { RRMS } \\
(n=1008)\end{array}$ & $\begin{array}{l}\text { IFN+GA: } 0.1 \text { (SD } \\
0.5 \text { ) vs. IFN: } 0.1 \\
\text { (SD 0.5), p>0.05 } \\
\text { IFN+GA: } 0.1 \text { (SD } \\
0.5 \text { ) vs. GA: } 0.2 \\
\text { (SD } 0.5), p>0.05 \\
\text { IFN: } 0.1 \text { (SD } 0.5) \\
\text { vs. GA: } 0.2 \text { (SD } \\
0.5 \text { ), p>0.05 }\end{array}$ & $\begin{array}{l}36 \text { months } \\
\text { after last } \\
\text { patient was } \\
\text { included }\end{array}$ \\
\hline & & $\begin{array}{l}\text { Calabresi et al., } \\
\text { Lancet Neurol 2014, } \\
\text { phase III } \\
\text { (FREEDOMS II study) }\end{array}$ & $\begin{array}{l}\text { RRMS } \\
(n=1083)\end{array}$ & $\begin{array}{l}\text { Fingolimod } \\
0.5 \mathrm{mg} \mathrm{PO} / \text { day: } \\
0.00(0.60) ; \\
\text { Placebo: }-0.07 \\
(0.54), \mathrm{p}=0.012\end{array}$ & 24 months \\
\hline & $\begin{array}{l}\% \text { patients with } \\
\text { decrease } \geq 20 \% \\
\text { in MSFC }\end{array}$ & $\begin{array}{l}\text { Lanzillo et al., Mult } \\
\text { Scler Journal 2015, } \\
\text { phase III (ARIANNA } \\
\text { study) }\end{array}$ & $\begin{array}{l}\text { RRMS } \\
(n=154)\end{array}$ & $\begin{array}{l}\text { IFN beta-1b eod } \\
\text { SC + } \\
\text { atorvastatin } \\
40 \mathrm{mg} \text { PO/day: } \\
0.08 \text {; } \\
\text { IFN beta-1b eod } \\
\text { SC }+ \text { placebo: } \\
0.09, p>0.05\end{array}$ & 24 months \\
\hline \multirow[t]{3}{*}{$\begin{array}{l}\text { Ambulation } \\
\text { index }\end{array}$} & Score at FU & $\begin{array}{l}\text { Johnson et al., } \\
\text { Neurology 1995, } \\
\text { phase III (The } \\
\text { Copolymer } 1 \\
\text { Multiple Sclerosis } \\
\text { Study) }\end{array}$ & $\begin{array}{l}\text { RRMS } \\
(n=251)\end{array}$ & $\begin{array}{l}\text { Glatiramer } \\
\text { acetate } 20 \mathrm{mg} \\
\text { SC/day: } 0.27 \\
\text { (SE 0.94); } \\
\text { Placebo: } 0.28 \\
\text { (SE } 0.93 \text { ), } \\
\text { p }>0.05\end{array}$ & 24 months \\
\hline & & $\begin{array}{l}\text { PRISMS (Prevention } \\
\text { of Relapses and } \\
\text { Disability by } \\
\text { Interferon beta-1a } \\
\text { Subcutaneously in } \\
\text { Multiple Sclerosis) } \\
\text { Study Group, Lancet } \\
\text { 1998, phase III } \\
\text { (PRISMS study) }\end{array}$ & $\begin{array}{l}\text { RRMS } \\
(n=560)\end{array}$ & $\begin{array}{l}\text { IFN beta-1a } \\
44 \mathrm{mcg} \text { SC tiw: } \\
\text { better than } \\
\text { placebo } \\
(\mathrm{p}<0.05) ; \text { no } \\
\text { further details } \\
\text { given }\end{array}$ & 24 months \\
\hline & $\begin{array}{l}\text { \% patients with } \\
\text { 3-month CDP } \\
\text { (t) }\end{array}$ & $\begin{array}{l}\text { PRISMS (Prevention } \\
\text { of Relapses and } \\
\text { Disability by } \\
\text { Interferon beta-1a } \\
\text { Subcutaneously in } \\
\text { Multiple Sclerosis) } \\
\text { Study Group, Lancet } \\
\text { 1998, phase III } \\
\text { (PRISMS study) }\end{array}$ & $\begin{array}{l}\text { RRMS } \\
(n=560)\end{array}$ & $\begin{array}{l}\text { IFN beta-1a } \\
22 \mathrm{mcg} \text { SC tiw: } \\
12 \%, p>0.05 \\
\text { (vs. placebo); } \\
\text { IFN beta-1a } \\
44 \mathrm{mcg} \text { SC tiw: } \\
7 \%, \text { p } \leq 0.05 \text { (vs. } \\
\text { placebo); } \\
\text { Placebo: } 13 \%\end{array}$ & 24 months \\
\hline Arm index & $\begin{array}{l}\text { Change from } \\
\text { baseline to FU }\end{array}$ & $\begin{array}{l}\text { PRISMS (Prevention } \\
\text { of Relapses and } \\
\text { Disability by } \\
\text { Interferon beta-1a } \\
\text { Subcutaneously in }\end{array}$ & $\begin{array}{l}\text { RRMS } \\
(n=560)\end{array}$ & $\begin{array}{l}\text { IFN beta-1a } \\
22 \text { mcg SC tiw, } \\
\text { IFN beta- } 1 \text { a } \\
44 \mathrm{mcg} \text { SC tiw, } \\
\text { placebo: no }\end{array}$ & 24 months \\
\hline
\end{tabular}




\begin{tabular}{|c|c|c|c|c|c|}
\hline & & $\begin{array}{l}\text { Multiple Sclerosis) } \\
\text { Study Group, Lancet } \\
\text { 1998, phase III } \\
\text { (PRISMS study) }\end{array}$ & & $\begin{array}{l}\text { changes in any } \\
\text { of the groups } \\
\text { (no differences } \\
\text { - no further } \\
\text { details given) }\end{array}$ & \\
\hline $\begin{array}{l}\text { Rao's Brief } \\
\text { Repeatable } \\
\text { Battery }\end{array}$ & $\begin{array}{l}\text { \% patients with } \\
\text { change in } \\
\text { cognitive } \\
\text { impairment (c) }\end{array}$ & $\begin{array}{l}\text { Lanzillo et al., Mult } \\
\text { Scler Journal 2015, } \\
\text { phase III (ARIANNA } \\
\text { study) }\end{array}$ & $\begin{array}{l}\text { RRMS } \\
(n=154)\end{array}$ & $\begin{array}{l}\text { IFN beta-1b SC } \\
\text { eod + } \\
\text { atorvastatin } \\
40 \mathrm{mg} / \mathrm{d}:-37.1 \\
\text { IFN beta-1b SC } \\
\text { eod + placebo: } \\
-35.2, \mathrm{p}>0.05\end{array}$ & 24 months \\
\hline \multirow[t]{3}{*}{$\begin{array}{l}\text { No evidence of } \\
\text { clinical activity } \\
\text { (NECA) }\end{array}$} & $\begin{array}{l}\text { \% of patients } \\
\text { with no } \\
\text { evidence of } \\
\text { clinical activity } \\
\text { (no relapses } \\
\text { and no } \\
\text { progression of } \\
\text { disability) }\end{array}$ & $\begin{array}{l}\text { Cohen et al., Lancet } \\
\text { 2012, phase III } \\
\text { (CARE-MS I study) }\end{array}$ & $\begin{array}{l}\text { RRMS } \\
\text { previously } \\
\text { untreated } \\
(n=581)\end{array}$ & $\begin{array}{l}\text { Alemtuzumab } \\
12 \mathrm{mg} \text { IV/day x } \\
5 \text { days: } 74 \% ; \\
\text { IFN beta } 1 \mathrm{a} \\
44 \mathrm{mcg} \text { SC tiw: } \\
56 \%, \mathrm{p}<0.0001\end{array}$ & 24 months \\
\hline & & $\begin{array}{l}\text { Coles et al., Lancet } \\
\text { 2012, phase III } \\
\text { (CARE-MS II study) }\end{array}$ & $\begin{array}{l}\text { RRMS } \\
\text { previously } \\
\text { treated } \\
(\mathrm{n}=840)\end{array}$ & $\begin{array}{l}\text { Alemtuzumab } \\
12 \mathrm{mg} \text { IV/day x } \\
5 \text { days: } 60 \% ; \\
\text { IFN beta } 1 \mathrm{a} \\
44 \mathrm{mcg} \text { SC tiw: } \\
41 \%, \mathrm{p}<0.0001\end{array}$ & 24 months \\
\hline & & $\begin{array}{l}\text { Lublin et al., Ann } \\
\text { Neurol 2013, phase } \\
\text { III (CombiRx study) }\end{array}$ & $\begin{array}{l}\text { RRMS } \\
(n=1008)\end{array}$ & $\begin{array}{l}\text { IFN+GA: } 45.4 \% \\
\text { vs. IFN: } 46.9 \% \text {, } \\
p=0.35 ; \\
\text { IFN+GA: } 45.4 \% \\
\text { vs. GA: } 47.4 \% \text {, } \\
p=0.35 ; \\
\text { IFN: } 46.9 \% \text { vs. } \\
\text { GA: } 47.4 \%, \\
p=0.92\end{array}$ & $\begin{array}{l}36 \text { months } \\
\text { after last } \\
\text { patient was } \\
\text { included }\end{array}$ \\
\hline \multirow[t]{2}{*}{$\begin{array}{l}\text { Unidimensional } \\
\text { Fatigue Impact } \\
\text { Scale (FIS or } \\
\text { UFIS) }\end{array}$} & $\begin{array}{l}\text { Change from } \\
\text { baseline to FU }\end{array}$ & $\begin{array}{l}\text { O'Connor et al., } \\
\text { NEJM 2011, phase } \\
\text { III (TEMSO study) }\end{array}$ & $\begin{array}{l}\text { Relapsing } \\
\text { MS }(n=1088)\end{array}$ & $\begin{array}{l}\text { Teriflunomide } \\
\text { 7mg PO/day: } \\
2.3 \text { (SD 1.6), p } \\
\text { (vs. placebo) = } \\
0.39 ; \\
\text { Teriflunomide } \\
\text { 14mg PO/day: } \\
3.8 \text { (SD 1.7), p } \\
\text { (vs. placebo) = } \\
0.83 ; \text { Placebo: } \\
4.3 \text { (SD 1.7) } \\
\end{array}$ & 108 weeks \\
\hline & & $\begin{array}{l}\text { Confavreux et al., } \\
\text { Lancet Neurol 2014, } \\
\text { phase III (TOWER } \\
\text { study) }\end{array}$ & $\begin{array}{l}\text { RRMS } \\
(n=1169)\end{array}$ & $\begin{array}{l}\text { Teriflunomide } \\
\text { 7mg: } 4.46 \\
\text { (1.66), p (vs. } \\
\text { placebo) = } \\
\text { 0.3686; } \\
\text { Teriflunomide } \\
\text { 14mg: } 2.04 \\
\text { (1.68), p (vs. } \\
\text { placebo) = } \\
0.0429 ;\end{array}$ & $\begin{array}{l}48 \text { weeks } \\
\text { after the } \\
\text { last patient } \\
\text { was } \\
\text { included }\end{array}$ \\
\hline
\end{tabular}




\begin{tabular}{|c|c|c|c|c|c|}
\hline & & & & $\begin{array}{l}\text { Placebo: } \\
6.31(1.67) ;\end{array}$ & \\
\hline & & $\begin{array}{l}\text { Vermersch et al., } \\
\text { MSJ 2014, phase III } \\
\text { (TENERE study) }\end{array}$ & $\begin{array}{l}\text { Relapsing } \\
\text { MS }(n=324)\end{array}$ & $\begin{array}{l}\text { Teriflunomide } \\
\text { 7mg: } 0.97 \\
\text { (2.96), p (vs. } \\
\text { placebo) = 0.03; } \\
\text { Teriflunomide } \\
\text { 14mg: } 4.10 \\
\text { (3.03), p (vs. } \\
\text { placebo) = } 0.18 \text {; } \\
\text { Placebo: } 9.10 \\
\text { (SE 3.21) }\end{array}$ & $\begin{array}{l}48 \text { weeks } \\
\text { after the } \\
\text { last patient } \\
\text { was } \\
\text { included }\end{array}$ \\
\hline MSIS-29 & $\begin{array}{l}\% \text { patients with } \\
\text { worsening in } \\
\text { MSIS-29 (global } \\
\text { score) }\end{array}$ & $\begin{array}{l}\text { Kappos et al., New } \\
\text { Engl J Med 2015, } \\
\text { phase III (DECIDE } \\
\text { study) }\end{array}$ & $\begin{array}{l}\text { RRMS } \\
(n=1841)\end{array}$ & $\begin{array}{l}\text { Daclizumab HYP } \\
\text { 150mg/4 } \\
\text { weeks: } 19 \% \\
\text { IFN beta-1a } \\
30 \text { mcg } \\
\text { IM/week: } 23 \% \\
\text { (d) }\end{array}$ & $\begin{array}{l}144 \text { weeks } \\
\text { (this } \\
\text { outcome } \\
\text { was } \\
\text { evaluated at } \\
96 \text { weeks) }\end{array}$ \\
\hline \multirow[t]{2}{*}{ SF-36 } & $\begin{array}{l}\text { Change in } \\
\text { physical } \\
\text { summary score } \\
\text { from baseline } \\
\text { to last FU }\end{array}$ & $\begin{array}{l}\text { Confavreux et al., } \\
\text { Lancet Neurol 2014, } \\
\text { phase III (TOWER } \\
\text { study) }\end{array}$ & $\begin{array}{l}\text { RRMS } \\
(n=1169)\end{array}$ & $\begin{array}{l}\text { Teriflunomide } \\
\text { 7mg: - } 0.91 \\
\text { (0.44), p (vs. } \\
\text { placebo) = } \\
0.1772 ; \\
\text { Teriflunomide } \\
\text { 14mg: }-0.64 \\
\text { (0.44), p (vs. } \\
\text { placebo) = } \\
0.0687 ; \\
\text { Placebo: }-1.63 \\
\text { (0.44) }\end{array}$ & $\begin{array}{l}48 \text { weeks } \\
\text { after the } \\
\text { last patient } \\
\text { was } \\
\text { included }\end{array}$ \\
\hline & $\begin{array}{l}\text { Change in } \\
\text { mental } \\
\text { summary score } \\
\text { from baseline } \\
\text { to last FU }\end{array}$ & $\begin{array}{l}\text { Confavreux et al., } \\
\text { Lancet Neurol 2014, } \\
\text { phase III (TOWER } \\
\text { study) }\end{array}$ & $\begin{array}{l}\text { RRMS } \\
(n=1169)\end{array}$ & $\begin{array}{l}\text { Teriflunomide } \\
7 \mathrm{mg}:-1.70 \\
\text { (0.60), p (vs. } \\
\text { placebo) = } \\
0.1363 ; \\
\text { Teriflunomide } \\
\text { 14mg: -1.09 } \\
\text { (0.59), p (vs. } \\
\text { placebo) = } \\
0.0224 ; \\
\text { Placebo: }-2.79 \\
\text { (0.59) }\end{array}$ & $\begin{array}{l}48 \text { weeks } \\
\text { after the } \\
\text { last patient } \\
\text { was } \\
\text { included }\end{array}$ \\
\hline \multirow[t]{2}{*}{ TSQM } & $\begin{array}{l}\text { Effectiveness } \\
\text { domain, score } \\
\text { at FU }\end{array}$ & $\begin{array}{l}\text { Vermersch et al., } \\
\text { MSJ 2014, phase III } \\
\text { (TENERE study) }\end{array}$ & $\begin{array}{l}\text { Relapsing } \\
\text { MS ( } n=324)\end{array}$ & $\begin{array}{l}\text { Teriflunomide } \\
\text { 7mg: } 67.25 \text { (SE } \\
\text { 2.70), p (vs. } \\
\text { placebo) = 0.02; } \\
\text { Teriflunomide } \\
\text { 14mg: } 63.13 \text { (SE } \\
\text { 2.75), p (vs. } \\
\text { placebo) = } 0.28 ; \\
\text { Placebo: } 59.30 \\
\text { (SE 2.97) }\end{array}$ & $\begin{array}{l}48 \text { weeks } \\
\text { after the } \\
\text { last patient } \\
\text { was } \\
\text { included }\end{array}$ \\
\hline & $\begin{array}{l}\text { Side-effects } \\
\text { domain, score } \\
\text { at FU }\end{array}$ & $\begin{array}{l}\text { Vermersch et al., } \\
\text { MSJ 2014, phase III } \\
\text { (TENERE study) }\end{array}$ & $\begin{array}{l}\text { Relapsing } \\
\text { MS }(n=324)\end{array}$ & $\begin{array}{l}\text { Teriflunomide } \\
\text { 7mg: } 95.29 \\
\text { (2.31), p (vs. }\end{array}$ & $\begin{array}{l}48 \text { weeks } \\
\text { after the } \\
\text { last patient }\end{array}$ \\
\hline
\end{tabular}




\begin{tabular}{|c|c|c|c|c|c|}
\hline & & & & $\begin{array}{l}\text { placebo) } \\
<0.0001 ; \\
\text { Teriflunomide } \\
\text { 14mg: } 93.15 \\
\text { (2.34), p (vs. } \\
\text { placebo) = } \\
<0.0001 ; \\
\text { Placebo: } 71.38 \\
\text { (SE 2.50) }\end{array}$ & $\begin{array}{l}\text { was } \\
\text { included }\end{array}$ \\
\hline & $\begin{array}{l}\text { Convenience } \\
\text { domain, score } \\
\text { at FU }\end{array}$ & $\begin{array}{l}\text { Vermersch et al., } \\
\text { MSJ 2014, phase III } \\
\text { (TENERE study) }\end{array}$ & $\begin{array}{l}\text { Relapsing } \\
\text { MS }(n=324)\end{array}$ & $\begin{array}{l}\text { Teriflunomide } \\
\text { 7mg: } 88.30 \\
\text { (1.97), p (vs. } \\
\text { placebo) } \\
<0.0001 ; \\
\text { Teriflunomide } \\
\text { 14mg: } 89.85 \\
\text { (1.98), p (vs. } \\
\text { placebo) } \\
<0.0001 ; \\
\text { Placebo: } 61.90 \\
\text { (SE 2.11) }\end{array}$ & $\begin{array}{l}48 \text { weeks } \\
\text { after the } \\
\text { last patient } \\
\text { was } \\
\text { included }\end{array}$ \\
\hline & $\begin{array}{l}\text { Global } \\
\text { satisfaction } \\
\text { domain, score } \\
\text { at FU }\end{array}$ & $\begin{array}{l}\text { Vermersch et al., } \\
\text { MSJ 2014, phase III } \\
\text { (TENERE study) }\end{array}$ & $\begin{array}{l}\text { Relapsing } \\
\text { MS }(n=324)\end{array}$ & $\begin{array}{l}\text { Teriflunomide } \\
\text { 7mg: } 68.29 \\
\text { (2.77), p (vs. } \\
\text { placebo) = 0.02; } \\
\text { Teriflunomide } \\
\text { 14mg: } 68.82 \\
\text { (2.78), p (vs. } \\
\text { placebo) = } 0.02 ; \\
\text { Placebo: } 60.98 \\
\text { (SE 2.94) }\end{array}$ & $\begin{array}{l}48 \text { weeks } \\
\text { after the } \\
\text { last patient } \\
\text { was } \\
\text { included }\end{array}$ \\
\hline \multirow[t]{3}{*}{$\begin{array}{l}\text { No evidence of } \\
\text { disease activity } \\
\text { (NEDA) }\end{array}$} & $\begin{array}{l}\text { \% of patients } \\
\text { with no } \\
\text { evidence of } \\
\text { disease activity } \\
\text { (no relapses + } \\
\text { no progression } \\
\text { of disability + } \\
\text { no MRI activity } \\
\text { (h)) }\end{array}$ & $\begin{array}{l}\text { Cohen et al., Lancet } \\
\text { 2012, phase III } \\
\text { (CARE-MS I study) }\end{array}$ & $\begin{array}{l}\text { RRMS } \\
\text { previously } \\
\text { untreated } \\
(n=581)\end{array}$ & $\begin{array}{l}\text { IFN beta } 1 a \\
44 \text { mcg SC tiw: } \\
27 \% \text { vs. } \\
\text { Alemtuzumab } \\
12 \mathrm{mg} \text { IV/day x } \\
5 \text { days: } 39 \% \text {, } \\
p=0.006\end{array}$ & 24 months \\
\hline & & $\begin{array}{l}\text { Coles et al., Lancet } \\
\text { 2012, phase III } \\
\text { (CARE-MS II study) }\end{array}$ & $\begin{array}{l}\text { RRMS } \\
\text { previously } \\
\text { treated } \\
(\mathrm{n}=840)\end{array}$ & $\begin{array}{l}\text { IFN beta } 1 a \\
44 \mathrm{mcg} \text { SC tiw: } \\
14 \% \text { vs. } \\
\text { Alemtuzumab } \\
12 \mathrm{mg} \text { IV/day x } \\
5 \text { days: } 32 \%, \\
p<0.0001\end{array}$ & 24 months \\
\hline & & $\begin{array}{l}\text { Lublin et al., Ann } \\
\text { Neurol 2013, phase } \\
\text { III (CombiRx study) }\end{array}$ & $\begin{array}{l}\text { RRMS } \\
(n=1008)\end{array}$ & $\begin{array}{l}\text { IFN+GA: } 26.9 \% \\
\text { vs. IFN: } 17.1 \% \text {, } \\
p=0.002 ; \\
\text { IFN+GA: } 26.9 \% \\
\text { vs. GA: } 16.1 \% \text {, } \\
p=0.001 ; \\
\text { IFN: } 17.1 \% \text { vs. } \\
\text { GA: } 16.1 \%, \\
p=0.762\end{array}$ & $\begin{array}{l}36 \text { months } \\
\text { after last } \\
\text { patient was } \\
\text { included }\end{array}$ \\
\hline
\end{tabular}




\section{Table footnote:}

(a) ARR refers to mean ARR per each group; it includes confirmed relapse rate, which includes rate of relapses with confirmed increase in EDSS (Voskuhl et al., Lancet Neurol 2016) and also adjusted mean relapse rate (Vollmer et al., J Neurol 2014)

(b) No detailed figures provided

(c) Cognitive impairment was defined on the number of failed tests, as mild (one to two tests failed) or moderate-severe (three or more tests failed)

(d) Defined as $\geq 7.5$ points increase in MSIS-29

(e) CDP: Confirmed disability progression was defined as an increase of Expanded Disability Status Scale score of at least 1.0 point for patients with a baseline score of 1.0 or more, or an increase of at least 1.5 points for patients with a baseline score of 0 , confirmed after 12 weeks. For the rest, EDSS increase of $\geq 1$ point if EDSS $\leq 5.5$; EDSS increase of $\geq 0.5$ point if EDSS > 5.5;

(f) Includes adjusted MSFC z-score; also it may include values obtained at an early termination time point if this occurred after 12 months.

(g) Includes time to sustained accumulation of disability, which is considered as increase in 1 point in EDSS sustained for a minimum of 12 weeks (Confavreux et al., Lancet Neurol 2014, TOWER trial)

(h) No MRI activity includes: no new/enlarging lesions and no gadolinium-enhancing lesions

(i) Includes relapses requiring hospitalization/IV steroids (Comi et al., NEJM 2012, ALLEGRO study)

(j) Adjusting for baseline values of MSFC z-score, ANCOVA model

(k) Mean change reported, unless otherwise specified

(I) It includes 'at least 1 major relapse'

(m) The authors also estimated the proportion of patients with: i) at least one MSrelated admission to hospital; ii) at least $1 \mathrm{MS}$-rekated steroid course

(n) The results shown refer to the comparative phase $(0-12 \mathrm{~m})$ of the trial, where half of the patients were receiving IFN beta-1a IM $30 \mathrm{mcg} /$ week and the other half IFN beta-1a SC $44 \mathrm{mcg}$ tiw.

(o) p-value not specified

(p) this analysis refers to disability progression in both hands

(q) worsening in 9HPT is defined as deterioration greater or equal to $20 \%$

(r) confirmed at 2 months

(s) mean number of relapses per patient during the trial/2 years (duration of trial)

(t) defined as 2-step increase (sustained for 3 months)

(u) in this context, this outcome measure (risk ratio or odds ratio) is equivalent to hazard ratio in the survival model

(v) timing for CDP not specified. Assumed 3 months

(w) this study looked at disability progression at the end of FU, so it is possible that just progression confirmed at just 3 months is also included here

(x) This refers to McDonald 2005 criteria

Abbreviations. BD: twice per day; CDP: confirmed disability progression; $\mathrm{Cl}$ : confidence interval; eod: every other day; FU: follow-up; GA: glatiramer acetate; HR: 
hazard ratio; IA \& AHSCT: immunoablation and autologous haemopoietic stem-cell transplantation; IFN: interferon; IQR: interquartile range; MIU: million international units; MSCT: mesenchymal stem cell transplantation; MSFC: Multiple Sclerosis Functional Composite; MSIS-29: Multiple Sclerosis Impact Scale - 29 items; PO: per oral; RFSS: Regional Functional System Score; SC: subcutaneous; SF-36: Short Form 36 Health Survey (SF-36); SNRS: Scripps Neurological Rating Scale; TDS: three times per day; tiw: three times in a week; TSQM: Treatment Satisfaction Questionnaire for Medication, with domains for Effectiveness, Side-Effects, Convenience and Global Satisfaction 
Table 2: Clinical outcome measures in phase III trials in clinically isolated syndromes (CIS)

\begin{tabular}{|c|c|c|c|c|c|}
\hline $\begin{array}{l}\text { Original clinical } \\
\text { outcome }\end{array}$ & $\begin{array}{l}\text { Derived } \\
\text { outcome } \\
\text { measures }\end{array}$ & Trial & $\begin{array}{l}\text { Condition } \\
\text { (no. of } \\
\text { patients } \\
\text { randomised) }\end{array}$ & $\begin{array}{l}\text { Drug, effect } \\
\text { (vs. placebo/ } \\
\text { another active } \\
\text { arm) }\end{array}$ & $\begin{array}{l}\text { Duration of } \\
\text { the trial }\end{array}$ \\
\hline \multirow[t]{5}{*}{ Relapses } & $\begin{array}{l}\text { Time to } \\
\text { CDMS }\end{array}$ & $\begin{array}{l}\text { Jacobs et al., } \\
\text { NEJM 2000, } \\
\text { phase III } \\
\text { (CHAMPS } \\
\text { study) }\end{array}$ & CIS (n=383) & $\begin{array}{l}\text { IFN beta-1a } \\
30 \mathrm{mcg} \text { IM/week } \\
\text { vs. placebo: rate } \\
\text { ratio }(95 \% \mathrm{Cl}) 0.56 \\
(0.38 \text { to } 0.81) \text {, } \\
\mathrm{p}=0002\end{array}$ & $\begin{array}{l}\text { Early } \\
\text { termination: } \\
\text { obvious } \\
\text { superiority } \\
\text { of IFN over } \\
\text { placebo } \\
\text { (initially } \\
\text { planned: } 36 \\
\text { months) }\end{array}$ \\
\hline & & $\begin{array}{l}\text { Comi et al., } \\
\text { Lancet 2001, } \\
\text { phase III } \\
\text { (ETOMS } \\
\text { study) }\end{array}$ & $\operatorname{CIS}(n=308)$ & $\begin{array}{l}\text { IFN beta-1a } \\
22 \mathrm{mcg} \text { SC/week: } \\
\text { mean time ( } 95 \% \\
\text { CI) } 569 \text { days ( } 317 \\
\text { to infinity) ( } 30^{\text {th }} \\
\text { percentile); } \\
\text { Placebo: mean } \\
\text { time ( } 95 \% \mathrm{Cl}) 252 \\
\text { days ( } 173 \text { to } 413) \\
\left(30^{\text {th }} \text { percentile), }\right. \\
p=0.034\end{array}$ & 24 months \\
\hline & & $\begin{array}{l}\text { Kappos et } \\
\text { al., } \\
\text { Neurology } \\
\text { 2006, phase } \\
\text { III (BENEFIT } \\
\text { study) }\end{array}$ & $\mathrm{CIS}(\mathrm{n}=487)$ & $\begin{array}{l}\text { IFN beta- } 1 \mathrm{~b} \\
250 \mathrm{mcg} \mathrm{SC} / \text { eod: } \\
\text { mean time: } 618 \\
\text { days ( } 25^{\text {th }} \\
\text { percentile), vs. } \\
\text { placebo: mean } \\
\text { time: } 255 \text { days } \\
\left(25^{\text {th }} \text { percentile); }\right. \\
\text { HR }(95 \% \mathrm{Cl}) 0.50 \\
(0.36 \text { to } 0.70) \text {, } \\
\text { p<0.0001 }\end{array}$ & 24 months \\
\hline & & $\begin{array}{l}\text { Comi et al., } \\
\text { Lancet 2009, } \\
\text { phase III } \\
\text { (PreCISe } \\
\text { study) }\end{array}$ & $\operatorname{CIS}(n=481)$ & $\begin{array}{l}\text { GA } 20 \mathrm{mg} \mathrm{SC} / \mathrm{day} \\
\text { vs. placebo: } \mathrm{HR} \\
(95 \% \mathrm{Cl}) 0.55 \\
(0.40 \text { to } 0.77) \\
\mathrm{p}=0.0005\end{array}$ & 36 months \\
\hline & & $\begin{array}{l}\text { Comi et al., } \\
\text { Lancet } \\
\text { Neurol 2012, } \\
\text { phase III } \\
\text { (REFLEX } \\
\text { study) }\end{array}$ & $\operatorname{CIS}(n=517)$ & 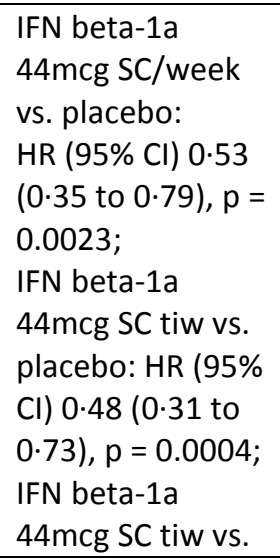 & 108 weeks \\
\hline
\end{tabular}




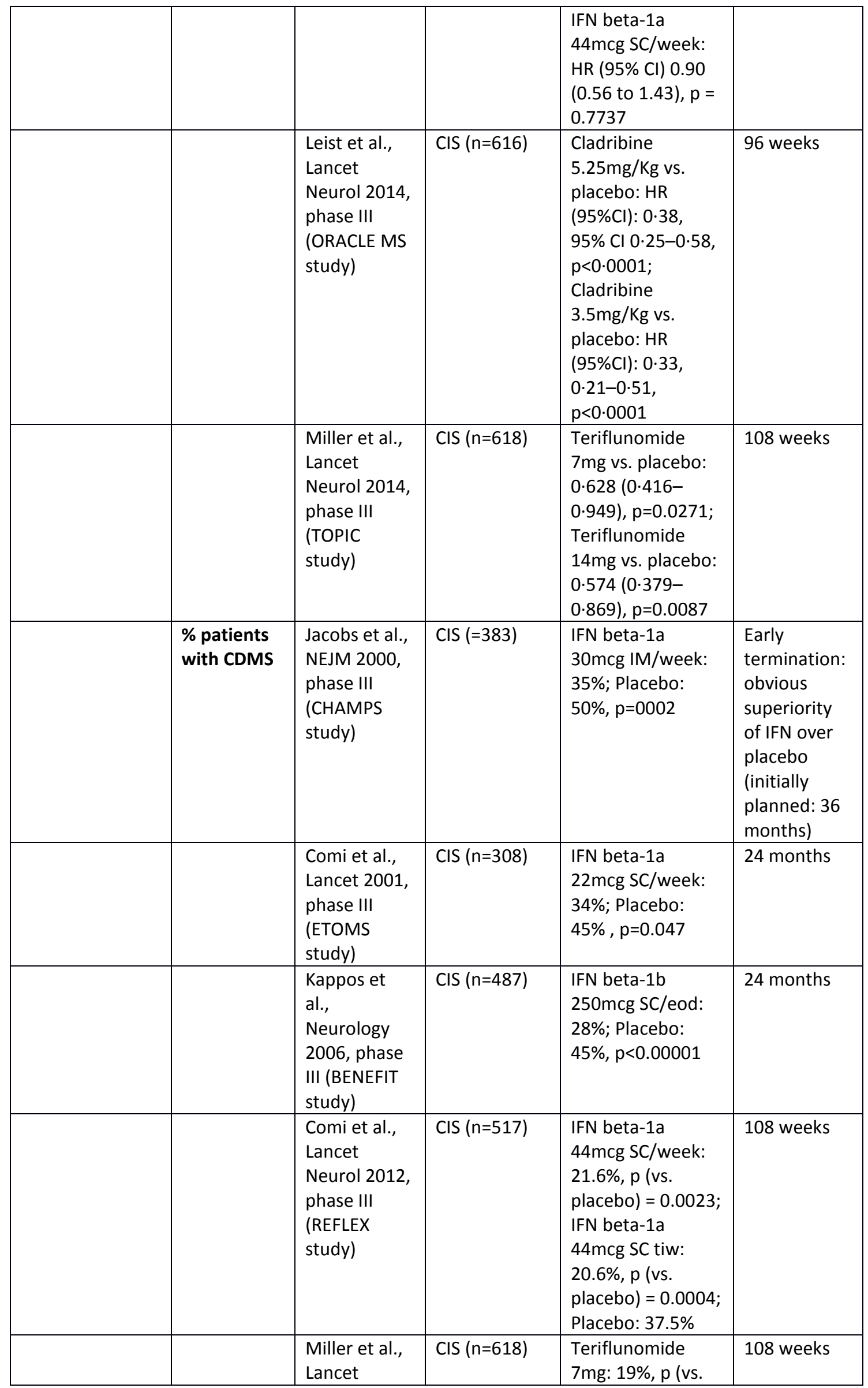




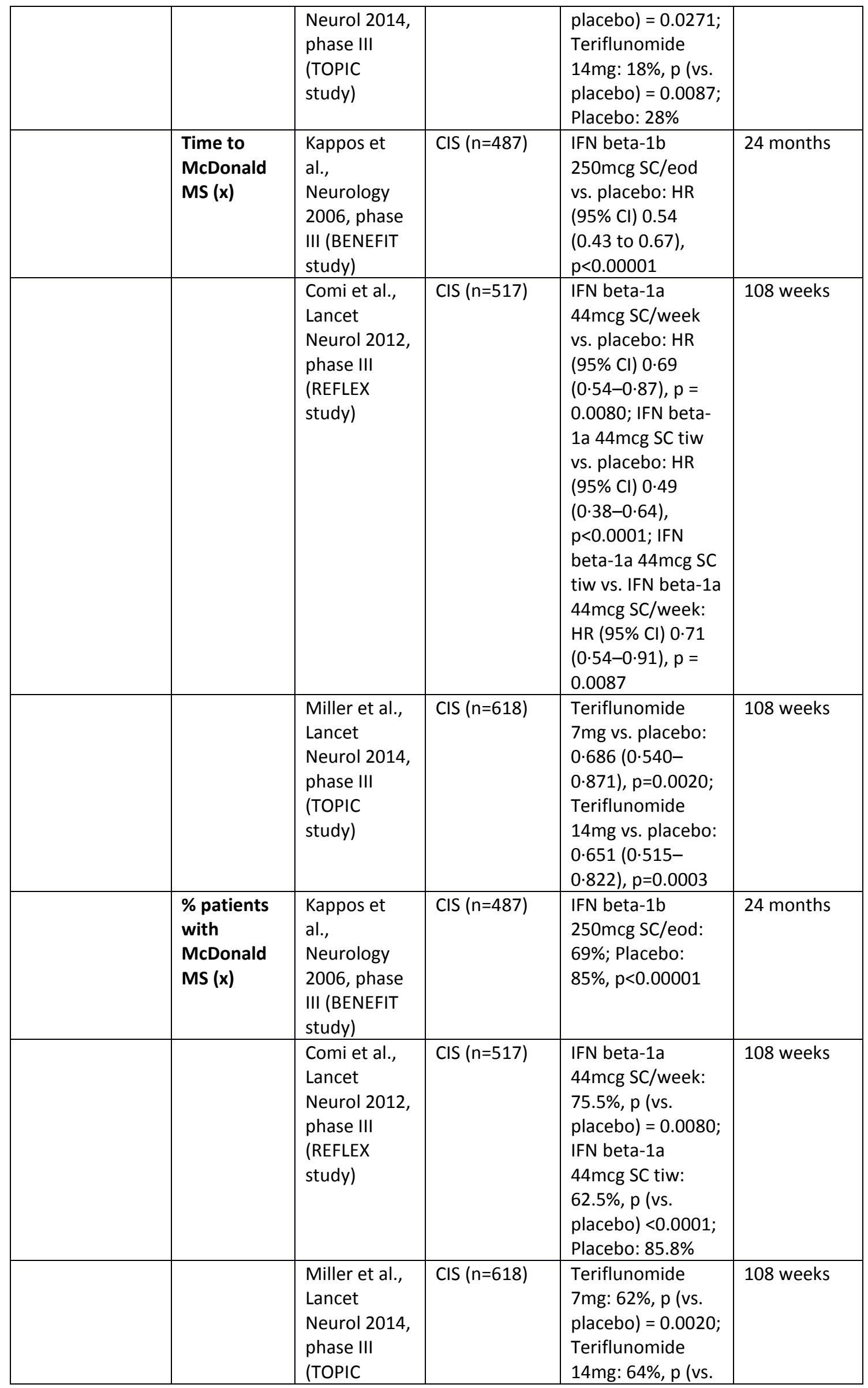




\begin{tabular}{|c|c|c|c|c|c|}
\hline & & study) & & $\begin{array}{l}\text { placebo) }=0.0003 ; \\
\text { Placebo: } 76 \%\end{array}$ & \\
\hline & $\begin{array}{l}\text { Mean } \\
\text { annualised } \\
\text { relapse rate } \\
\text { (a) }\end{array}$ & $\begin{array}{l}\text { Comi et al., } \\
\text { Lancet 2001, } \\
\text { phase III } \\
\text { (ETOMS } \\
\text { study) }\end{array}$ & CIS $(n=308)$ & $\begin{array}{l}\text { IFN beta-1a } \\
22 \mathrm{mcg} \text { SC/week: } \\
0.33 ; \text { Placebo: } \\
0.43, p=0.045\end{array}$ & 24 months \\
\hline & & $\begin{array}{l}\text { Miller et al., } \\
\text { Lancet } \\
\text { Neurol 2014, } \\
\text { phase III } \\
\text { (TOPIC } \\
\text { study) }\end{array}$ & CIS $(n=618)$ & $\begin{array}{l}\text { Teriflunomide } \\
7 \mathrm{mg}: 0 \cdot 190 \\
(0 \cdot 139-0 \cdot 260), p \\
\text { (vs. placebo) }= \\
0.0541 ; \\
\text { Teriflunomide } \\
14 \mathrm{mg}: 0 \cdot 194 \\
(0 \cdot 143-0 \cdot 263), p \\
\text { (vs. placebo) }= \\
0.0579 ; \text { Placebo: } \\
0 \cdot 284(0 \cdot 214- \\
0 \cdot 378)\end{array}$ & 108 weeks \\
\hline & $\begin{array}{l}\% \text { patients } \\
\text { with at } \\
\text { least } 1 \\
\text { relapse (a) } \\
\text { (I) }\end{array}$ & $\begin{array}{l}\text { Comi et al., } \\
\text { Lancet 2009, } \\
\text { phase III } \\
\text { (PreCISe } \\
\text { study) }\end{array}$ & $\operatorname{CIS}(n=481)$ & $\begin{array}{l}\text { Placebo: } 42.9 \% \\
\text { GA 20mg SC/day: } \\
24.7 \%, p<0.0001\end{array}$ & 36 months \\
\hline \multirow[t]{4}{*}{ EDSS score } & $\begin{array}{l}\text { Change in } \\
\text { EDSS score } \\
\text { from } \\
\text { baseline to } \\
\text { follow-up } \\
\text { (k) }\end{array}$ & $\begin{array}{l}\text { Comi et al., } \\
\text { Lancet 2001, } \\
\text { phase III } \\
\text { (ETOMS } \\
\text { study) }\end{array}$ & $\operatorname{CIS}(n=308)$ & $\begin{array}{l}\text { IFN beta-1a } \\
22 \mathrm{mcg} \text { SC/week: } \\
\text { median (IQR) } 0 \text { (-1 } \\
\text { to 0); Placebo: } \\
\text { median (IQR) } 0 \text { (-1 } \\
\text { to 0), } \mathrm{p}=0.521\end{array}$ & 24 months \\
\hline & & $\begin{array}{l}\text { Miller et al., } \\
\text { Lancet } \\
\text { Neurol 2014, } \\
\text { phase III } \\
\text { (TOPIC } \\
\text { study) }\end{array}$ & CIS $(n=618)$ & $\begin{array}{l}\text { Teriflunomide } \\
\text { 7mg: }-0.250 \text { (SD } \\
0.937), p \text { (vs. } \\
\text { placebo) = 0.0334; } \\
\text { Teriflunomide } \\
\text { 14mg: }-0.265 \text { (SD } \\
0.849 \text { ), p (vs. } \\
\text { placebo) }=0.0443 \text {; } \\
\text { Placebo: }-0.056 \\
\text { (SD 0.955) }\end{array}$ & 108 weeks \\
\hline & $\begin{array}{l}\text { Time to 3- } \\
\text { month CDP } \\
\text { (g) }\end{array}$ & $\begin{array}{l}\text { Miller et al., } \\
\text { Lancet } \\
\text { Neurol 2014, } \\
\text { phase III } \\
\text { (TOPIC } \\
\text { study) }\end{array}$ & $\operatorname{CIS}(n=618)$ & $\begin{array}{l}\text { Teriflunomide } \\
\text { 7mg PO vs. } \\
\text { Placebo: HR } 0.978 \\
\text { (0.521-1.835), } \\
\text { p=0.9953; } \\
\text { Teriflunomide } \\
\text { 14mg PO vs. } \\
\text { placebo: HR } 0.701 \\
(0.360-1.366) \\
\text { p=0.4244 }\end{array}$ & 108 weeks \\
\hline & $\begin{array}{l}\text { \% patients } \\
\text { with 3- } \\
\text { month CDP }\end{array}$ & $\begin{array}{l}\text { Comi et al., } \\
\text { Lancet 2001, } \\
\text { phase III } \\
\text { (ETOMS } \\
\text { study) }\end{array}$ & CIS $(n=308)$ & $\begin{array}{l}\text { IFN beta-1a } \\
22 \mathrm{mcg} \text { SC/week: } \\
\text { 15\%; Placebo: } \\
20 \% \text {, p-value not } \\
\text { specified } \\
\text { (probably not }\end{array}$ & 24 months \\
\hline
\end{tabular}




\begin{tabular}{|c|c|c|c|c|c|}
\hline & & & & significant) (w) & \\
\hline & & $\begin{array}{l}\text { Miller et al., } \\
\text { Lancet } \\
\text { Neurol 2014, } \\
\text { phase III } \\
\text { (TOPIC } \\
\text { study) }\end{array}$ & CIS $(n=618)$ & $\begin{array}{l}\text { Teriflunomide } \\
7 \mathrm{mg}: 10 \%, \mathrm{p} \text { (vs. } \\
\text { placebo) = 0.9953; } \\
\text { Teriflunomide } \\
\text { 14mg: } 7 \%, \mathrm{p} \text { (vs. } \\
\text { placebo) }=0.4244 ; \\
\text { Placebo: } 10 \%\end{array}$ & 108 weeks \\
\hline SNRS & $\begin{array}{l}\text { Change } \\
\text { from } \\
\text { baseline to } \\
\text { FU }\end{array}$ & $\begin{array}{l}\text { Comi et al., } \\
\text { Lancet 2001, } \\
\text { phase III } \\
\text { (ETOMS } \\
\text { study) }\end{array}$ & CIS $(n=308)$ & $\begin{array}{l}\text { IFN beta-1a } \\
22 \mathrm{mcg} \text { SC/week: } \\
\text { median (IQR) } 0 \text { (-1 } \\
\text { to 2); Placebo: } \\
\text { median (IQR) } 0 \text { (-1 } \\
\text { to 2), } \mathrm{p}=0.747\end{array}$ & 24 months \\
\hline $\begin{array}{l}\text { Unidimensional } \\
\text { Fatigue Impact } \\
\text { Scale (FIS or } \\
\text { UFIS) }\end{array}$ & $\begin{array}{l}\text { Change } \\
\text { from } \\
\text { baseline to } \\
\text { FU }\end{array}$ & $\begin{array}{l}\text { Miller et al., } \\
\text { Lancet } \\
\text { Neurol 2014, } \\
\text { phase III } \\
\text { (TOPIC } \\
\text { study) }\end{array}$ & CIS $(n=618)$ & $\begin{array}{l}\text { Teriflunomide } \\
7 \mathrm{mg}:-2 \cdot 730 \text { (SD } \\
30 \cdot 410), \mathrm{p} \text { (vs. } \\
\text { placebo) = 0.9974; } \\
\text { Teriflunomide } \\
\text { 14mg: }-4 \cdot 487 \text { (SD } \\
\text { 32.519), p (vs. } \\
\text { placebo) = } 0.8492 ; \\
\text { Placebo: }-3.535 \\
\text { (29.298); }\end{array}$ & 108 weeks \\
\hline
\end{tabular}

\section{Table footnote:}

(a) ARR refers to mean ARR per each group; it includes confirmed relapse rate, which includes rate of relapses with confirmed increase in EDSS (Voskuhl et al., Lancet Neurol 2016) and also adjusted mean relapse rate (Vollmer et al., J Neurol 2014)

(b) No detailed figures provided

(c) Cognitive impairment was defined on the number of failed tests, as mild (one to two tests failed) or moderate-severe (three or more tests failed)

(d) Defined as $\geq 7.5$ points increase in MSIS-29

(e) CDP: Confirmed disability progression was defined as an increase of Expanded Disability Status Scale score of at least 1.0 point for patients with a baseline score of 1.0 or more, or an increase of at least 1.5 points for patients with a baseline score of 0 , confirmed after 12 weeks. For the rest, EDSS increase of $\geq 1$ point if EDSS $\leq 5.5$; EDSS increase of $\geq 0.5$ point if EDSS $>5.5$;

(f) Includes adjusted MSFC z-score; also it may include values obtained at an early termination time point if this occurred after 12 months.

(g) Includes time to sustained accumulation of disability, which is considered as increase in 1 point in EDSS sustained for a minimum of 12 weeks (Confavreux et al., Lancet Neurol 2014, TOWER trial)

(h) No MRI activity includes: no new/enlarging lesions and no gadolinium-enhancing lesions

(i) Includes relapses requiring hospitalization/IV steroids (Comi et al., NEJM 2012, ALLEGRO study)

(j) Adjusting for baseline values of MSFC z-score, ANCOVA model

(k) Mean change reported, unless otherwise specified 
(I) It includes 'at least 1 major relapse'

(m) The authors also estimated the proportion of patients with: i) at least one MSrelated admission to hospital; ii) at least 1 MS-rekated steroid course

(n) The results shown refer to the comparative phase $(0-12 \mathrm{~m})$ of the trial, where half of the patients were receiving IFN beta-1a IM $30 \mathrm{mcg} /$ week and the other half IFN beta-1a SC $44 \mathrm{mcg}$ tiw.

(o) p-value not specified

(p) this analysis refers to disability progression in both hands

(q) worsening in 9HPT is defined as deterioration greater or equal to $20 \%$

(r) confirmed at 2 months

(s) mean number of relapses per patient during the trial/2 years (duration of trial)

(t) defined as 2-step increase (sustained for 3 months)

(u) in this context, this outcome measure (risk ratio or odds ratio) is equivalent to hazard ratio in the survival model

(v) timing for CDP not specified. Assumed 3 months

(w) this study looked at disability progression at the end of FU, so it is possible that just progression confirmed at just 3 months is also included here

(x) This refers to McDonald 2005 criteria

Abbreviations. BD: twice per day; CDP: confirmed disability progression; $\mathrm{Cl}$ : confidence interval; eod: every other day; FU: follow-up; GA: glatiramer acetate; HR: hazard ratio; IA \& AHSCT: immunoablation and autologous haemopoietic stem-cell transplantation; IFN: interferon; IQR: interquartile range; MIU: million international units; MSCT: mesenchymal stem cell transplantation; MSFC: Multiple Sclerosis Functional Composite; MSIS-29: Multiple Sclerosis Impact Scale - 29 items; PO: per oral; RFSS: Regional Functional System Score; SC: subcutaneous; SF-36: Short Form 36 Health Survey (SF-36); SNRS: Scripps Neurological Rating Scale; TDS: three times per day; tiw: three times in a week; TSQM: Treatment Satisfaction Questionnaire for Medication, with domains for Effectiveness, Side-Effects, Convenience and Global Satisfaction 
Table 3: Clinical outcome measures in phase III trials in progressive MS

\begin{tabular}{|c|c|c|c|c|c|}
\hline $\begin{array}{l}\text { Original clinical } \\
\text { outcome }\end{array}$ & $\begin{array}{l}\text { Derived outcome } \\
\text { measures }\end{array}$ & Trial & $\begin{array}{l}\text { Condition (no. of } \\
\text { patients } \\
\text { randomised) }\end{array}$ & $\begin{array}{l}\text { Drug, effect } \\
\text { (vs. placebo/ } \\
\text { another active } \\
\text { arm) }\end{array}$ & $\begin{array}{l}\text { Duration of the } \\
\text { trial }\end{array}$ \\
\hline \multirow[t]{7}{*}{ Relapses } & $\begin{array}{l}\text { Mean annualised } \\
\text { relapse rate }(a)\end{array}$ & $\begin{array}{l}\text { European Study } \\
\text { Group on IFN } \\
\text { beta-1b in SPMS, } \\
\text { Lancet 1998, } \\
\text { phase III (EUSPMS } \\
\text { study) }\end{array}$ & SPMS ( $n=718)$ & $\begin{array}{l}\text { IFN beta-1b } 8 \\
\text { million IU eod: } \\
0.44 ; \text { Placebo: } \\
0.64, p=0.0002\end{array}$ & $\begin{array}{l}\text { Early termination: } \\
\text { obvious } \\
\text { superiority of IFN } \\
\text { vs. placebo } \\
\text { (initially planned: } \\
39 \text { months) }\end{array}$ \\
\hline & & $\begin{array}{l}\text { SPECTRIMS study } \\
\text { group, Neurology } \\
2001 \text { (SPECTRIMS } \\
\text { study) }\end{array}$ & SPMS ( $n=618)$ & $\begin{array}{l}\text { IFN beta- } 1 \mathrm{a} \\
22 \mathrm{mcg} \text { SC tiw: } \\
0.50(0.44 \text { to } \\
0.56), \mathrm{p} \text { (vs. } \\
\text { placebo) <0.001; } \\
\text { IFN beta-1a } \\
44 \mathrm{mcg} \mathrm{SC} \text { tiw: } \\
0.50 \text { ( } 0.45 \text { to } \\
0.56), \mathrm{p} \text { (vs. } \\
\text { Placebo) }<0.001 ; \\
\text { Placebo: } 0.71 \\
\text { (0.65 to } 0.78)\end{array}$ & 36 months \\
\hline & & $\begin{array}{l}\text { Andersen et al., } \\
\text { JNNP 2004, phase } \\
\text { III (The Nordic } \\
\text { SPMS study) }\end{array}$ & SPMS $(n=371)$ & $\begin{array}{l}\text { IFN beta-1a SC } \\
22 \mathrm{mcg} / \text { week: } \\
0.25 ; \\
\text { Placebo: } 0.27 \\
p=0.55\end{array}$ & 36 months \\
\hline & & $\begin{array}{l}\text { Hommes et al., } \\
\text { Lancet 2004, } \\
\text { phase III (ESIMS } \\
\text { study) }\end{array}$ & SPMS ( $n=318)$ & $\begin{array}{l}\text { IVIG } \\
1 \mathrm{~g} / \mathrm{Kg} / \text { month: } \\
0.46 \\
\text { Placebo: } 0.46 \\
p>0.05\end{array}$ & 24 months \\
\hline & & $\begin{array}{l}\text { North American } \\
\text { Study Group on } \\
\text { IFN beta-1b in } \\
\text { SPMS, Neurology } \\
2004 \text {, phase III } \\
\text { (NASPMS study) }\end{array}$ & SPMS ( $n=939)$ & $\begin{array}{l}\text { Pooled IFN beta- } \\
1 \mathrm{~b}(250 \mathrm{mcg} \text { SC } \\
\text { eod or } \\
160 \mathrm{mcg} / \mathrm{m} 2 \mathrm{SC} \\
\text { eod) vs. placebo: } \\
\text { reduction of ARR } \\
\text { in } 36 \%, p<0.05\end{array}$ & $\begin{array}{l}\text { Early termination } \\
\text { for futility } \\
\text { (initially planned: } \\
36 \text { months) }\end{array}$ \\
\hline & & $\begin{array}{l}\text { Freedman et al., } \\
\text { Neurology 2011, } \\
\text { phase III } \\
\text { (MAESTRO study) }\end{array}$ & SPMS (n=612) & $\begin{array}{l}\text { MBP8298 500mg } \\
\text { IV/6 months: } \\
0.13 ; \\
\text { Placebo: } 0.14 \\
p=0.633\end{array}$ & 24 months \\
\hline & $\begin{array}{l}\text { Mean annualised } \\
\text { severe relapse } \\
\text { rate (i) }\end{array}$ & $\begin{array}{l}\text { SPECTRIMS study } \\
\text { group, Neurology } \\
2001 \text { (SPECTRIMS } \\
\text { study) }\end{array}$ & SPMS ( $n=618)$ & $\begin{array}{l}\text { IFN beta-1a } \\
22 \mathrm{mcg} \text { SC tiw: } \\
0.26(0.22 \text { to } \\
0.31), p(v s . \\
\text { placebo) }=0.002 ; \\
\text { IFN beta-1a }\end{array}$ & 36 months \\
\hline
\end{tabular}




\begin{tabular}{|c|c|c|c|c|}
\hline & & & $\begin{array}{l}44 \mathrm{mcg} \text { SC tiw: } \\
0.27(0.23 \text { to } \\
0.31), \mathrm{p} \text { (vs. } \\
\text { placebo) }=0.003 \\
\text { Placebo: } 0.39 \\
\text { (0.34 to } 0.44)\end{array}$ & \\
\hline $\begin{array}{l}\% \text { patients with } \\
\text { at least } 1 \text { relapse } \\
\text { (a) (I) }\end{array}$ & $\begin{array}{l}\text { Hommes et al., } \\
\text { Lancet 2004, } \\
\text { phase III, (ESIMS } \\
\text { study) }\end{array}$ & SPMS $(n=318)$ & $\begin{array}{l}\text { IVIG } \\
\text { 1g/Kg/month: } \\
48.4 \%, p=0.58 \\
\text { Placebo: } 52.2 \%\end{array}$ & 24 months \\
\hline $\begin{array}{l}\text { \% relapse-free } \\
\text { patients at the } \\
\text { end of FU }\end{array}$ & $\begin{array}{l}\text { Andersen et al., } \\
\text { JNNP 2004, phase } \\
\text { III (The Nordic } \\
\text { SPMS study) }\end{array}$ & SPMS $(n=371)$ & $\begin{array}{l}\text { IFN beta-1a SC } \\
22 \mathrm{mcg} / \text { week: } \\
61 \% ; \\
\text { Placebo: } 62 \% \text {, } \\
\text { p=0.89 }\end{array}$ & 36 months \\
\hline & $\begin{array}{l}\text { North American } \\
\text { Study Group on } \\
\text { IFN beta-1b in } \\
\text { SPMS, Neurology } \\
2004 \text {, phase III } \\
\text { (NASPMS study) }\end{array}$ & SPMS ( $n=939)$ & $\begin{array}{l}\text { IFN beta-1b } \\
250 \mathrm{mcg} \text { SC eod: } \\
71 \%, \mathrm{p} \text { (vs. } \\
\text { Placebo) }=0.018 \\
\text { Placebo: } 62 \%\end{array}$ & $\begin{array}{l}\text { Early termination } \\
\text { for futility } \\
\text { (initially planned: } \\
36 \text { months) }\end{array}$ \\
\hline $\begin{array}{l}\text { Time to first } \\
\text { confirmed } \\
\text { relapse }\end{array}$ & $\begin{array}{l}\text { European Study } \\
\text { Group on IFN } \\
\text { beta-1b in SPMS, } \\
\text { Lancet 1998, } \\
\text { phase III (EUSPMS } \\
\text { study) }\end{array}$ & SPMS $(n=718)$ & $\begin{array}{l}\text { Median time: } \\
\text { Placebo: } 403 \\
\text { days; IFN beta-1b } \\
8 \text { million IU eod: } \\
644 \text { days, } \\
p=0.0083\end{array}$ & 39 months \\
\hline & $\begin{array}{l}\text { SPECTRIMS study } \\
\text { group, Neurology } \\
2001 \text { (SPECTRIMS } \\
\text { study) }\end{array}$ & SPMS $(n=618)$ & $\begin{array}{l}\text { IFN beta-1a } \\
22 \mathrm{mcg} S C \text { tiw vs. } \\
\text { placebo: } H R= \\
0.87(0.69 \text { to } \\
1.10), p=0.237 ; \\
\text { IFN beta-1a } \\
44 m c g \text { SC tiw vs. } \\
\text { placebo: HR } 0.77 \\
(0.61 \text { to } 0.98), \\
p=0.034 ;\end{array}$ & 36 months \\
\hline & $\begin{array}{l}\text { Andersen et al., } \\
\text { JNNP 2004, phase } \\
\text { III (The Nordic } \\
\text { SPMS study) }\end{array}$ & SPMS $(n=371)$ & $\begin{array}{l}\text { IFN beta-1a SC } \\
22 \mathrm{mcg} / \text { week vs. } \\
\text { placebo: no } \\
\text { differences (not } \\
\text { specified) }\end{array}$ & 36 months \\
\hline & $\begin{array}{l}\text { North American } \\
\text { Study Group on } \\
\text { IFN beta-1b in } \\
\text { SPMS, Neurology } \\
2004 \text {, phase III } \\
\text { (NASPMS study) }\end{array}$ & SPMS ( $n=939)$ & $\begin{array}{l}\text { Placebo: } 487 \text { days } \\
\text { ( } 30^{\text {th }} \text { percentile) } \\
\text { IFN beta-1b } \\
250 \text { mcg SC eod: } \\
1051 \text { days }\left(30^{\text {th }}\right. \\
\text { percentile), } \\
p=0.010\end{array}$ & $\begin{array}{l}\text { Early termination } \\
\text { for futility } \\
\text { (initially planned: } \\
36 \text { months) }\end{array}$ \\
\hline $\begin{array}{l}\text { Time between } \\
\text { first and second } \\
\text { relapse }\end{array}$ & $\begin{array}{l}\text { SPECTRIMS study } \\
\text { group, Neurology } \\
2001 \text { (SPECTRIMS }\end{array}$ & SPMS $(n=618)$ & $\begin{array}{l}\text { IFN beta-1a } \\
22 \mathrm{mcg} \text { SC tiw vs. } \\
\text { placebo: } H R=\end{array}$ & 36 months \\
\hline
\end{tabular}




\begin{tabular}{|c|c|c|c|c|c|}
\hline & & study) & & $\begin{array}{l}0.50(0.37 \text { to } \\
0.69), p<0.001 ; \\
\text { IFN beta-1a } \\
44 m c g \text { SC tiw vs. } \\
\text { placebo: } \mathrm{HR}= \\
0.60(0.44 \text { to } \\
0.81), p=0.001\end{array}$ & \\
\hline & $\begin{array}{l}\text { Mean annualised } \\
\text { hospitalisation } \\
\text { rate due to MS } \\
\text { exacerbations }\end{array}$ & $\begin{array}{l}\text { SPECTRIMS study } \\
\text { group, Neurology } \\
2001 \text { (SPECTRIMS } \\
\text { study) }\end{array}$ & SPMS $(n=618)$ & $\begin{array}{l}\text { IFN beta-1a } \\
22 \mathrm{mcg} \text { SC tiw: } \\
0.14 \text { ( } 0.11 \text { to } \\
0.17), p \text { (vs. } \\
\text { placebo) = } 0.006 ; \\
\text { IFN beta-1a } \\
44 \mathrm{mcg} \text { SC tiw: } \\
0.15(0.12 \text { to } \\
0.18), p \text { (vs. } \\
\text { placebo) }=0.005 ; \\
\text { Placebo: } 0.22 \\
\text { (0.18 to } 0.26 \text { ); }\end{array}$ & 36 months \\
\hline & $\begin{array}{l}\text { Mean annualised } \\
\text { rate of steroid } \\
\text { courses }\end{array}$ & $\begin{array}{l}\text { SPECTRIMS study } \\
\text { group, Neurology } \\
2001 \text { (SPECTRIMS } \\
\text { study) }\end{array}$ & SPMS $(n=618)$ & $\begin{array}{l}\text { IFN beta-1a } \\
22 \mathrm{mcg} \text { SC tiw: } \\
0.31 \text { ( } 0.27 \text { to } \\
0.36), p \text { (vs. } \\
\text { placebo) = } 0.001 ; \\
\text { IFN beta-1a } \\
44 \mathrm{mcg} \text { SC tiw: } \\
0.34 \text { ( } 0.30 \text { to } \\
0.39), p \text { (vs. } \\
\text { placebo) }=0.006 ; \\
\text { Placebo: } 0.52 \\
\text { (0.46 to } 0.58 \text { ); }\end{array}$ & 36 months \\
\hline \multirow[t]{4}{*}{ EDSS score } & Score at FU & $\begin{array}{l}\text { European Study } \\
\text { Group on IFN } \\
\text { beta-1b in SPMS, } \\
\text { Lancet 1998, } \\
\text { phase III (EUSPMS } \\
\text { study) }\end{array}$ & SPMS $(n=718)$ & $\begin{array}{l}\text { IFN beta-1b } 8 \\
\text { million IU eod: } \\
5.57 \text {; placebo: } \\
5.84, p=0.0750\end{array}$ & 39 months \\
\hline & $\begin{array}{l}\text { Change in EDSS } \\
\text { score from } \\
\text { baseline to } \\
\text { follow-up (k) }\end{array}$ & $\begin{array}{l}\text { European Study } \\
\text { Group on IFN } \\
\text { beta-1b in SPMS, } \\
\text { Lancet 1998, } \\
\text { phase III (EUSPMS } \\
\text { study) }\end{array}$ & SPMS $(n=718)$ & $\begin{array}{l}\text { IFN beta-1b } 8 \\
\text { million IU eod: } \\
0.47 ; \\
\text { Placebo: } 0.60 \\
p=0.0299\end{array}$ & 39 months \\
\hline & & $\begin{array}{l}\text { Cohen et al., } \\
\text { Neurology } 2002 \\
\text { (IMPACT study) }\end{array}$ & SPMS $(n=436)$ & $\begin{array}{l}\text { IFN beta-1a } \\
60 \mathrm{mcg} / \text { week IM } \\
\text { vs. placebo: mean } \\
\text { change } 0.258 \text { vs. } \\
0.272, \\
\text { respectively, } \\
p=0.362\end{array}$ & 24 months \\
\hline & & $\begin{array}{l}\text { Andersen et al., } \\
\text { JNNP 2004, phase } \\
\text { III (The Nordic }\end{array}$ & SPMS $(n=371)$ & $\begin{array}{l}\text { IFN beta-1a SC } \\
22 \mathrm{mcg} / \text { week vs. } \\
\text { placebo: no }\end{array}$ & 36 months \\
\hline
\end{tabular}




\begin{tabular}{|c|c|c|c|c|}
\hline & SPMS study) & & $\begin{array}{l}\text { differences (no } \\
\text { further details } \\
\text { given) }\end{array}$ & \\
\hline & $\begin{array}{l}\text { Hommes et al., } \\
\text { Lancet 2004, } \\
\text { phase III, (ESIMS } \\
\text { study) }\end{array}$ & SPMS $(n=318)$ & $\begin{array}{l}\text { IVIG } \\
1 \mathrm{~g} / \mathrm{Kg} / \text { month: } \\
\text { median change } \\
\text { (range): } 0.5 \text { (-3.0 } \\
\text { to } 5.0) ; \text { Placebo: } \\
0.5 \text { (-3.0 to } 5.0) \text {, } \\
\text { p>0.05 }\end{array}$ & 24 months \\
\hline & $\begin{array}{l}\text { North American } \\
\text { Study Group on } \\
\text { IFN beta-1b in } \\
\text { SPMS, Neurology } \\
\text { 2004, phase III } \\
\text { (NASPMS study) }\end{array}$ & SPMS ( $n=939)$ & $\begin{array}{l}\text { Pooled IFN beta- } \\
1 \mathrm{~b}(250 \mathrm{mcg} \text { SC } \\
\text { eod or } \\
160 \mathrm{mcg} / \mathrm{m} 2 \mathrm{SC} \\
\text { eod) vs. placebo: } \\
\text { no difference (no } \\
\text { further details } \\
\text { given) }\end{array}$ & $\begin{array}{l}\text { Early termination } \\
\text { for futility } \\
\text { (initially planned: } \\
36 \text { months) }\end{array}$ \\
\hline & $\begin{array}{l}\text { Wolinsky et al., } \\
\text { Ann Neurol 2007, } \\
\text { phase III } \\
\text { (PROMiSe study) }\end{array}$ & PPMS ( $n=943)$ & $\begin{array}{l}\text { GA 20mg SC/day: } \\
0.58 \text { (SD 1.00); } \\
\text { Placebo: HR (95\% } \\
\text { Cl): } 0.61 \text { (SD } \\
1.13), p>0.05\end{array}$ & $\begin{array}{l}\text { Early termination } \\
\text { for futility } \\
\text { (initially planned: } \\
36 \text { months) }\end{array}$ \\
\hline & $\begin{array}{l}\text { Hawker et al., Ann } \\
\text { Neurol 2009, } \\
\text { phase II/3 } \\
\text { (OLYMPUS study) }\end{array}$ & PPMS ( $\mathrm{n}=439)$ & $\begin{array}{l}\text { Rituximab } \\
\text { 1000mg IV/24 } \\
\text { weeks: } 0.33 \text { (1.0); } \\
\text { Placebo: } 0.45 \text { (SD } \\
1.0), p=0.34\end{array}$ & 96 weeks \\
\hline & $\begin{array}{l}\text { Freedman et al., } \\
\text { Neurology 2011, } \\
\text { phase III } \\
\text { (MAESTRO study) }\end{array}$ & SPMS (n=612) & $\begin{array}{l}\text { MBP8298 500mg } \\
\text { IV/6 months: } 0.22 \\
\text { (SE 0.06); } \\
\text { Placebo: } 0.17 \text { (SE } \\
0.06), p=0.465\end{array}$ & 24 months \\
\hline Time to EDSS 7.0 & $\begin{array}{l}\text { European Study } \\
\text { Group on IFN } \\
\text { beta-1b in SPMS, } \\
\text { Lancet 1998, } \\
\text { phase III (EUSPMS } \\
\text { study) }\end{array}$ & SPMS ( $\mathrm{n}=718$ ) & $\begin{array}{l}\text { IFN beta- } 1 \mathrm{~b} 8 \\
\text { million IU eod vs. } \\
\text { placebo: OR ( } 95 \% \\
\text { Cl) } 0.66 \text { ( } 0.47 \text { to } \\
0.93), p=0.0133\end{array}$ & 39 months \\
\hline $\begin{array}{l}\text { Time to 3-month } \\
\text { CDP (g) }\end{array}$ & $\begin{array}{l}\text { European Study } \\
\text { Group on IFN } \\
\text { beta-1b in SPMS, } \\
\text { Lancet 1998, } \\
\text { phase III (EUSPMS } \\
\text { study) }\end{array}$ & SPMS ( $\mathrm{n}=718)$ & $\begin{array}{l}\text { IFN beta-1b } 8 \\
\text { million IU eod vs. } \\
\text { placebo: odds } \\
\text { ratio of } 0.65 \text { ( } 95 \% \\
\text { Cl } 0.52-0.83), p \\
=0.0008(\mathbf{u})\end{array}$ & 39 months \\
\hline & $\begin{array}{l}\text { SPECTRIMS study } \\
\text { group, Neurology } \\
2001 \text { (SPECTRIMS } \\
\text { study) }\end{array}$ & SPMS (n=618) & $\begin{array}{l}\text { IFN beta- } 1 \text { a } \\
22 \mathrm{mcg} \text { SC tiw vs. } \\
\text { placebo: HR } 0.88 \text {, } \\
p=0.305 ; \text { IFN } \\
\text { beta- } 1 \text { a } 44 \mathrm{mcg} \text { SC } \\
\text { tiw vs. placebo: } \\
\text { HR }(95 \% \text { CI) } 0.83\end{array}$ & 36 months \\
\hline
\end{tabular}




\begin{tabular}{|c|c|c|c|c|}
\hline & & & $\begin{array}{l}\text { (0.65 to } 1.07) \\
p=0.146\end{array}$ & \\
\hline & $\begin{array}{l}\text { Cohen et al., } \\
\text { Neurology } 2002 \\
\text { (IMPACT study) }\end{array}$ & SPMS $(n=436)$ & $\begin{array}{l}\text { IFN beta-1a } \\
60 \mathrm{mcg} / \text { week IM } \\
\text { vs. placebo: HR } \\
(95 \% \mathrm{Cl}): 0.977 \\
(0.679 \text { to } 1.407) \text {, } \\
\mathrm{p}=0.90\end{array}$ & 24 months \\
\hline & $\begin{array}{l}\text { Hommes et al., } \\
\text { Lancet 2004, } \\
\text { phase III, (ESIMS } \\
\text { study) }\end{array}$ & SPMS $(n=318)$ & $\begin{array}{l}\text { IVIG } 1 \mathrm{~g} / \mathrm{Kg} / \text { month } \\
\text { vs. placebo: HR } \\
\text { (95\% CI) } 1.11(0.80 \\
\text { to } 1.53), p=0.53\end{array}$ & 24 months \\
\hline & $\begin{array}{l}\text { Wolinsky et al., } \\
\text { Ann Neurol 2007, } \\
\text { phase III } \\
\text { (PROMiSe study) }\end{array}$ & PPMS ( $n=943)$ & $\begin{array}{l}\text { GA } 20 \mathrm{mg} \mathrm{SC} / \text { day } \\
\text { vs. placebo: HR } \\
\text { ( } 95 \% \mathrm{Cl}) 0.87 \\
(0.71 \text { to } 1.07) \\
\mathrm{p}=0.1753\end{array}$ & 36 months \\
\hline & $\begin{array}{l}\text { Hawker et al., Ann } \\
\text { Neurol 2009, } \\
\text { phase II/3 } \\
\text { (OLYMPUS study) }\end{array}$ & PPMS ( $n=439)$ & $\begin{array}{l}\text { Rituximab } \\
1000 \mathrm{mg} \text { IV } / 24 \\
\text { weeks vs. } \\
\text { placebo: HR ( } 95 \% \\
\text { Cl) } 0.77 \text { ( } 0.55 \text { to } \\
1.09 \text { ), } p=0.1442\end{array}$ & 96 weeks \\
\hline & $\begin{array}{l}\text { Lublin et al., } \\
\text { Lancet 2016, } \\
\text { INFORMS study, } \\
\text { phase III }\end{array}$ & PPMS ( $n=970)$ & $\begin{array}{l}\text { Fingolimod } \\
0.5 \mathrm{mg} / \mathrm{d} \text { vs. } \\
\text { placebo: } \mathrm{HR}(95 \% \\
\mathrm{Cl}) 0.88(0.71 \text { to } \\
1.08), \mathrm{p}=0.217\end{array}$ & 36 months \\
\hline & $\begin{array}{l}\text { Montalban et al., } \\
\text { N Engl J Med. } \\
2016 \text { (ORATORIO } \\
\text { study) }\end{array}$ & PPMS ( $n=732)$ & $\begin{array}{l}\text { Ocrelizumab } \\
600 \mathrm{mg}(300 \mathrm{mg} \\
\text { x2) / } 24 \text { weeks IV } \\
\text { vs. placebo: } \\
\text { HR=0.76; } \\
p=0.0321\end{array}$ & 120 weeks \\
\hline $\begin{array}{l}\text { \% patients with } \\
\text { 3-month CDP }\end{array}$ & $\begin{array}{l}\text { European Study } \\
\text { Group on IFN } \\
\text { beta-1b in SPMS, } \\
\text { Lancet 1998, } \\
\text { phase III (EUSPMS } \\
\text { study) }\end{array}$ & SPMS ( $n=718)$ & $\begin{array}{l}\text { IFN beta-1b } 8 \\
\text { million IU eod: } \\
\text { 38.9\%; } \\
\text { Placebo: } 49.7 \%, p \\
=0.0048\end{array}$ & 39 months \\
\hline & $\begin{array}{l}\text { SPECTRIMS study } \\
\text { group, Neurology } \\
2001 \text { (SPECTRIMS } \\
\text { study) }\end{array}$ & SPMS ( $n=618)$ & $\begin{array}{l}\text { IFN beta-1a } \\
22 \text { mcg SC tiw: no } \\
\text { differences vs. } \\
\text { placebo (no more } \\
\text { details reported); } \\
\text { IFN beta-1a } \\
44 m c g \text { SC tiw: no } \\
\text { differences vs. } \\
\text { placebo (no more } \\
\text { details reported) }\end{array}$ & 36 months \\
\hline & $\begin{array}{l}\text { Hommes et al., } \\
\text { Lancet 2004, }\end{array}$ & SPMS $(n=318)$ & $\begin{array}{l}\text { IVIG } \\
1 \mathrm{~g} / \mathrm{Kg} / \text { month: }\end{array}$ & 24 months \\
\hline
\end{tabular}




\begin{tabular}{|c|c|c|c|c|}
\hline & $\begin{array}{l}\text { phase III (ESIMS } \\
\text { study) }\end{array}$ & & $\begin{array}{l}\text { 48.4\%; } \\
\text { Placebo: } 44 \% \text {, } \\
p=0.53\end{array}$ & \\
\hline & $\begin{array}{l}\text { Wolinsky et al., } \\
\text { Ann Neurol 2007, } \\
\text { phase III } \\
\text { (PROMiSe study) }\end{array}$ & PPMS ( $n=943)$ & $\begin{array}{l}\text { GA 20mg SC/day: } \\
39.6 \% \text {; } \\
\text { Placebo: } 45.2 \% \text {, } \\
\text { p>0.05 }\end{array}$ & 36 months \\
\hline & $\begin{array}{l}\text { Hawker et al., Ann } \\
\text { Neurol 2009, } \\
\text { phase II/3 } \\
\text { (OLYMPUS study) }\end{array}$ & PPMS (n=439) & $\begin{array}{l}\text { Placebo: } 38.5 \% \text {; } \\
\text { Rituximab } \\
1000 \mathrm{mg} \text { IV/24 } \\
\text { weeks: } 30.2 \% \text {, } \\
\text { p=0.1442 }\end{array}$ & 96 weeks \\
\hline & $\begin{array}{l}\text { Lublin et al., } \\
\text { Lancet 2016, } \\
\text { INFORMS study, } \\
\text { phase III }\end{array}$ & PPMS (n=970) & $\begin{array}{l}\text { Fingolimod } \\
0.5 \mathrm{mg} / \mathrm{d} \text { vs. } \\
\text { placebo: } 54.3 \% \\
\text { (47.16-61.45) vs. } \\
58.7 \%(53.30- \\
64.18), \mathrm{p}>0.05\end{array}$ & 36 months \\
\hline $\begin{array}{l}\text { Time to 6-month } \\
\text { CDP }\end{array}$ & $\begin{array}{l}\text { Andersen et al., } \\
\text { JNNP 2004, phase } \\
\text { III (The Nordic } \\
\text { SPMS study) }\end{array}$ & SPMS $(n=371)$ & $\begin{array}{l}\text { IFN beta-1a SC } \\
\text { 22mcg/week vs. } \\
\text { placebo: HR (95\% } \\
\text { CI) } 1.13 \text { (0.82 to } \\
\text { 1.57), } p=0.45\end{array}$ & 36 months \\
\hline & $\begin{array}{l}\text { North American } \\
\text { Study Group on } \\
\text { IFN beta-1b in } \\
\text { SPMS, Neurology } \\
\text { 2004, phase III } \\
\text { (NASPMS study) }\end{array}$ & SPMS ( $n=939)$ & $\begin{array}{l}\text { Pooled IFN beta- } \\
1 b \text { ( } 250 \mathrm{mcg} S C \\
\text { eod or } \\
160 \mathrm{mcg} / \mathrm{m} 2 \mathrm{SC} \\
\text { eod) vs. placebo: } \\
\text { no difference, } \\
\mathrm{p}=0.712\end{array}$ & $\begin{array}{l}\text { Early termination } \\
\text { for futility } \\
\text { (initially planned: } \\
36 \text { months) }\end{array}$ \\
\hline & $\begin{array}{l}\text { Freedman et al., } \\
\text { Neurology 2011, } \\
\text { phase III } \\
\text { (MAESTRO study) }\end{array}$ & SPMS $(n=612)$ & $\begin{array}{l}\text { MBP8298 500mg } \\
\text { IV/6 months vs. } \\
\text { placebo: HRs not } \\
\text { reported, but not } \\
\text { significant }\end{array}$ & 24 months \\
\hline & $\begin{array}{l}\text { Zajicek et al., } \\
\text { Lancet Neurol } \\
\text { 2013, phase } \\
\text { unspecified } \\
\text { (CUPID study) }\end{array}$ & $\begin{array}{l}\text { PPMS ( } n=191) \\
\text { SPMS ( } n=302) \\
\text { (randomised: } \\
n=498)\end{array}$ & $\begin{array}{l}\text { Dronabinol (max. } \\
\text { dose: } 28 \mathrm{mg} / \text { day, } \\
\text { titrated against } \\
\text { bodyweight) vs. } \\
\text { placebo: HR ( } 95 \% \\
\text { Cl) } 0.92 \text { ( } 0.68 \text { to } \\
1.23), p=0.57\end{array}$ & 36 months \\
\hline & $\begin{array}{l}\text { Lublin et al., } \\
\text { Lancet } 2016 \\
\text { (INFORMS study) }\end{array}$ & PPMS $(n=970)$ & $\begin{array}{l}\text { Fingolimod } \\
\text { 0.5mg/d vs. } \\
\text { placebo: HR ( } 95 \% \\
\text { CI) no different } \\
\text { from } 1.0 \text { ( } p>0.05, \\
\text { data not shown, } \\
\text { no further details } \\
\text { given) }\end{array}$ & 36 months \\
\hline & $\begin{array}{l}\text { Montalban et al., } \\
\text { N Engl J Med. }\end{array}$ & PPMS $(n=732)$ & $\begin{array}{l}\text { Ocrelizumab } \\
\text { 600mg (300mg }\end{array}$ & 120 weeks \\
\hline
\end{tabular}




\begin{tabular}{|c|c|c|c|c|c|}
\hline & & $\begin{array}{l}2016 \text { (ORATORIO } \\
\text { study) }\end{array}$ & & $\begin{array}{l}\text { x2) } / 24 \text { weeks IV } \\
\text { vs. placebo: } H R= \\
0.75 ; p=0.0365\end{array}$ & \\
\hline & $\begin{array}{l}\text { \% patients with } \\
\text { 6-month CDP }\end{array}$ & $\begin{array}{l}\text { Andersen et al., } \\
\text { JNNP 2004, phase } \\
\text { III (The Nordic } \\
\text { SPMS study) }\end{array}$ & SPMS $(n=371)$ & $\begin{array}{l}\text { IFN beta-1a SC } \\
22 \mathrm{mcg} / \text { week: } \\
41 \% \text {; } \\
\text { Placebo: } 38 \% \text {, } \\
\text { p=0.45 }\end{array}$ & 36 months \\
\hline & & $\begin{array}{l}\text { Hawker et al., Ann } \\
\text { Neurol 2009, } \\
\text { phase II/3 } \\
\text { (OLYMPUS study) }\end{array}$ & PPMS ( $n=439)$ & $\begin{array}{l}\text { Rituximab } \\
\text { 1000mg IV/24 } \\
\text { weeks: } 27.3 \% \text {; } \\
\text { Placebo: } 30.4 \% \text {, } \\
p=0.59\end{array}$ & 96 weeks \\
\hline & & $\begin{array}{l}\text { Freedman et al., } \\
\text { Neurology 2011, } \\
\text { phase III } \\
\text { (MAESTRO study) }\end{array}$ & SPMS $(n=612)$ & $\begin{array}{l}\text { MBP8298 500mg } \\
\text { IV/6 months: } \\
30.7 \% \text {; } \\
\text { Placebo: } 27.8 \% \text {, } \\
p=0.527 \text { (in } \\
\text { patients DR2+ or } \\
\text { DR4+) }\end{array}$ & 24 months \\
\hline & & $\begin{array}{l}\text { Lublin et al., } \\
\text { Lancet } 2016 \\
\text { (INFORMS study) }\end{array}$ & PPMS ( $n=970)$ & $\begin{array}{l}\text { Fingolimod } \\
0.5 \mathrm{mg} / \mathrm{d} \text { vs. } \\
\text { placebo: similar } \\
\text { percentages } \\
\text { ( }>0.05, \text { data not } \\
\text { shown, no further } \\
\text { details given) }\end{array}$ & 36 months \\
\hline & $\begin{array}{l}\text { IDSS: Integrated } \\
\text { Disability Status } \\
\text { Score (IDSS, } \\
\text { defined by area } \\
\text { under an EDSS } \\
\text { time-curve } \\
\text { adjusted for } \\
\text { baseline }\end{array}$ & $\begin{array}{l}\text { SPECTRIMS study } \\
\text { group, Neurology } \\
2001 \text { (SPECTRIMS } \\
\text { study) }\end{array}$ & SPMS ( $n=618)$ & $\begin{array}{l}\text { IFN beta-1a } \\
22 \text { mcg SC tiw: no } \\
\text { differences vs. } \\
\text { placebo (no more } \\
\text { details reported); } \\
\text { IFN beta-1a } \\
44 m c g \text { SC tiw: no } \\
\text { differences vs. } \\
\text { placebo (no more } \\
\text { details reported) }\end{array}$ & 36 months \\
\hline \multirow[t]{2}{*}{ TWT z-score } & $\begin{array}{l}\text { Change in TWT z- } \\
\text { score from } \\
\text { baseline to FU }\end{array}$ & $\begin{array}{l}\text { Cohen et al., } \\
\text { Neurology } 2002 \\
\text { (IMPACT study) }\end{array}$ & SPMS $(n=436)$ & $\begin{array}{l}\text { IFN beta-1a } \\
60 \mathrm{mcg} / \text { week IM } \\
\text { vs. placebo (SD): } \\
0.979 \text { (2.62) vs. } \\
1.191(3.13) \\
p=0.378\end{array}$ & 24 months \\
\hline & & $\begin{array}{l}\text { Hawker et al., Ann } \\
\text { Neurol 2009, } \\
\text { phase II/3 } \\
\text { (OLYMPUS study) }\end{array}$ & PPMS ( $n=439)$ & $\begin{array}{l}\text { Rituximab } \\
1000 \mathrm{mg} \text { IV/24 } \\
\text { weeks: (median) - } \\
0.08 \text {; } \\
\text { Placebo: (median) } \\
-0.14 \text { (greater } \\
\text { worsening than } \\
\text { rituximab arm), } \\
\mathrm{p}=0.015\end{array}$ & 96 weeks \\
\hline
\end{tabular}




\begin{tabular}{|c|c|c|c|c|c|}
\hline & & $\begin{array}{l}\text { Freedman et al., } \\
\text { Neurology 2011, } \\
\text { phase III } \\
\text { (MAESTRO study) }\end{array}$ & SPMS ( $n=612)$ & $\begin{array}{l}\text { MBP8298 500mg } \\
\text { IV/6 months: } \\
0.99 ; \\
\text { Placebo: } 1.57 \\
\text { p=0.096 }\end{array}$ & 24 months \\
\hline & $\begin{array}{l}\text { Time to 3-month } \\
\text { CDP }\end{array}$ & $\begin{array}{l}\text { Lublin et al., } \\
\text { Lancet } 2016 \\
\text { (INFORMS study) }\end{array}$ & PPMS $(n=970)$ & $\begin{array}{l}\text { Fingolimod } 0.5 \mathrm{mg} \\
\text { PO/day vs. } \\
\text { placebo: HR ( } 95 \% \\
\text { Cl) 0.94 (0.78 to } \\
\text { 1.14), p=0.546; }\end{array}$ & 36 months \\
\hline & $\begin{array}{l}\text { \% patients with } \\
\text { 3-month CDP }\end{array}$ & $\begin{array}{l}\text { Lublin et al., } \\
\text { Lancet } 2016 \\
\text { (INFORMS study) }\end{array}$ & PPMS ( $n=970)$ & $\begin{array}{l}\text { Fingolimod } \\
0.5 \mathrm{mg} / \mathrm{d}: 62.9 \% \\
\text { (57.10 to } 68.62) \\
\text { Placebo: } 70.0 \% \\
(61.78 \text { to } 78.21) \\
p=0.546\end{array}$ & 36 months \\
\hline & & $\begin{array}{l}\text { Montalban et al., } \\
\text { N Engl J Med. } \\
2016 \text { (ORATORIO } \\
\text { study) }\end{array}$ & PPMS ( $n=732)$ & $\begin{array}{l}\text { Ocrelizumab } \\
600 \mathrm{mg}(300 \mathrm{mg} \\
\text { x2) /24 weeks IV } \\
\text { vs. placebo: } 39 \% \\
\text { vs. } 55 \%, p=0.0404\end{array}$ & 120 weeks \\
\hline & $\begin{array}{l}\text { Time to 6-month } \\
\text { CDP }\end{array}$ & $\begin{array}{l}\text { Lublin et al., } \\
\text { Lancet } 2016 \\
\text { (INFORMS study) }\end{array}$ & PPMS ( $n=970)$ & $\begin{array}{l}\text { Fingolimod 0.5mg } \\
\text { PO/day vs. } \\
\text { placebo: similar } \\
\text { to 3-month CDP } \\
\text { analysis (no } \\
\text { further details } \\
\text { given) }\end{array}$ & 36 months \\
\hline & $\begin{array}{l}\text { \% patients with } \\
6 \text {-month CDP }\end{array}$ & $\begin{array}{l}\text { Lublin et al., } \\
\text { Lancet } 2016 \\
\text { (INFORMS study) }\end{array}$ & PPMS ( $n=970)$ & $\begin{array}{l}\text { Fingolimod 0.5mg } \\
\text { PO/day vs. } \\
\text { placebo: similar } \\
\text { to 3-month CDP } \\
\text { analysis (no } \\
\text { further details } \\
\text { given) }\end{array}$ & 36 months \\
\hline \multirow[t]{4}{*}{ 9HPT z-score } & $\begin{array}{l}\text { Change in 9HPT z- } \\
\text { score from } \\
\text { baseline to FU }\end{array}$ & $\begin{array}{l}\text { Cohen et al., } \\
\text { Neurology } 2002 \\
\text { (IMPACT study) }\end{array}$ & SPMS $(n=436)$ & \begin{tabular}{|l} 
IFN beta-1a \\
$60 \mathrm{mcg} /$ week IM \\
vs. placebo: 0.202 \\
(SD 0.476) vs. \\
0.290 (SD 0.494), \\
$\mathrm{p}=0.024$
\end{tabular} & 24 months \\
\hline & & $\begin{array}{l}\text { Freedman et al., } \\
\text { Neurology 2011, } \\
\text { phase III } \\
\text { (MAESTRO study) }\end{array}$ & SPMS $(n=612)$ & $\begin{array}{l}\text { MBP8298 500mg } \\
\text { IV/6 months: - } \\
\text { 0.08; } \\
\text { Placebo: }-0.04 \\
p=0.537\end{array}$ & 24 months \\
\hline & $\begin{array}{l}\text { Time to 3-month } \\
\text { CDP }\end{array}$ & $\begin{array}{l}\text { Hommes et al., } \\
\text { Lancet 2004, } \\
\text { phase III, (ESIMS } \\
\text { study) (q) }\end{array}$ & SPMS $(n=318)$ & $\begin{array}{l}\text { IVIG } 1 \mathrm{~g} / \mathrm{Kg} / \text { month } \\
\text { vs. placebo: HR } \\
\text { (95\% CI) } 1.09 \\
(0.75 \text { to } 1.59) \\
\mathrm{p}=0.67\end{array}$ & 24 months \\
\hline & & Lublin et al., & PPMS ( $n=970)$ & Fingolimod $0.5 \mathrm{mg}$ & 36 months \\
\hline
\end{tabular}




\begin{tabular}{|c|c|c|c|c|c|}
\hline & & $\begin{array}{l}\text { Lancet } 2016 \\
\text { (INFORMS study) }\end{array}$ & & $\begin{array}{l}\text { PO/day vs. } \\
\text { placebo: HR ( } 95 \% \\
\text { Cl) 0.93 }(0.71- \\
1.22), p=0.607 ;\end{array}$ & \\
\hline & $\begin{array}{l}\text { \% patients with } \\
\text { 3-month CDP }\end{array}$ & $\begin{array}{l}\text { Hommes et al., } \\
\text { Lancet 2004, } \\
\text { phase III, (ESIMS } \\
\text { study) (q) }\end{array}$ & SPMS $(n=318)$ & $\begin{array}{l}\text { IVIG } 1 \mathrm{~g} / \mathrm{Kg} / \text { month } \\
\text { vs. placebo: } \\
34.6 \% \text {; } \\
\text { Placebo: } 33.3 \% \text {, } \\
p=0.67 \text { (p) }\end{array}$ & 24 months \\
\hline & & $\begin{array}{l}\text { Lublin et al., } \\
\text { Lancet } 2016 \\
\text { (INFORMS study) }\end{array}$ & PPMS ( $n=970)$ & $\begin{array}{l}\text { Fingolimod 0.5mg } \\
\text { PO/day: } 33.6 \% \\
\text { (26.11-41.08); } \\
\text { Placebo: } 41.3 \% \\
(32.10-50.55), p= \\
0.607\end{array}$ & 36 months \\
\hline & $\begin{array}{l}\text { Time to 6-month } \\
\text { CDP }\end{array}$ & $\begin{array}{l}\text { Lublin et al., } \\
\text { Lancet } 2016 \\
\text { (INFORMS study) }\end{array}$ & PPMS ( $n=970)$ & $\begin{array}{l}\text { Fingolimod } 0.5 \mathrm{mg} \\
\text { PO/day vs. } \\
\text { placebo: similar } \\
\text { to 3-month CDP } \\
\text { analysis (no } \\
\text { further details } \\
\text { given) }\end{array}$ & 36 months \\
\hline & $\begin{array}{l}\text { \% patients with } \\
\text { 6-month CDP }\end{array}$ & $\begin{array}{l}\text { Lublin et al., } \\
\text { Lancet } 2016 \\
\text { (INFORMS study) }\end{array}$ & PPMS ( $n=970)$ & $\begin{array}{l}\text { Fingolimod } 0.5 \mathrm{mg} \\
\text { PO/day vs. } \\
\text { placebo: similar } \\
\text { to 3-month CDP } \\
\text { analysis (no } \\
\text { further details } \\
\text { given) }\end{array}$ & 36 months \\
\hline \multirow[t]{2}{*}{ PASAT z-score } & $\begin{array}{l}\text { Change from } \\
\text { baseline to FU }\end{array}$ & $\begin{array}{l}\text { Cohen et al., } \\
\text { Neurology } 2002 \\
\text { (IMPACT study) }\end{array}$ & SPMS $(n=436)$ & $\begin{array}{l}\text { IFN beta-1a } \\
60 \mathrm{mcg} / \text { week IM } \\
\text { vs. placebo: } 0.094 \\
\text { (SD 0.498) vs. } \\
0.004 \text { (SD 0.473), } \\
p=0.061\end{array}$ & 24 months \\
\hline & & $\begin{array}{l}\text { Freedman et al., } \\
\text { Neurology 2011, } \\
\text { phase III } \\
\text { (MAESTRO study) }\end{array}$ & SPMS $(n=612)$ & $\begin{array}{l}\text { MBP8298 500mg } \\
\text { IV/6 months: } \\
0.24 ; \\
\text { Placebo: } 0.17 \\
p=0.393\end{array}$ & 24 months \\
\hline \multirow[t]{2}{*}{ MSFC } & $\begin{array}{l}\text { Change in MSFC } \\
\text { z-score from } \\
\text { baseline to } \\
\text { follow-up (f) (k) }\end{array}$ & $\begin{array}{l}\text { Cohen et al., } \\
\text { Neurology } 2002 \\
\text { (IMPACT study) }\end{array}$ & SPMS $(n=436)$ & $\begin{array}{l}\text { IFN beta-1a } \\
60 \mathrm{mcg} / \text { week IM } \\
\text { vs. placebo: } 0.362 \\
\text { (SD 1.41) vs. } \\
0.495 \text { (SD 1.58), } \\
p=0.033\end{array}$ & 24 months \\
\hline & & $\begin{array}{l}\text { Wolinsky et al., } \\
\text { Ann Neurol 2007, } \\
\text { phase III } \\
\text { (PROMiSe study) }\end{array}$ & PPMS ( $n=943)$ & $\begin{array}{l}\text { GA } 20 \mathrm{mg} \text { SC/day } \\
\text { vs. placebo: no } \\
\text { differences } \\
\text { between groups } \\
\text { (no further details } \\
\text { given) }\end{array}$ & 36 months \\
\hline
\end{tabular}




\begin{tabular}{|c|c|c|c|c|c|}
\hline & & $\begin{array}{l}\text { Hawker et al., Ann } \\
\text { Neurol 2009, } \\
\text { phase II/3 } \\
\text { (OLYMPUS study) }\end{array}$ & PPMS (n=439) & $\begin{array}{l}\text { Rituximab } \\
1000 \mathrm{mg} \text { IV/24 } \\
\text { weeks: median } \\
\text { change }-0.06 ; \\
\text { Placebo: median } \\
\text { change }-0.10, \\
p=0.089\end{array}$ & 96 weeks \\
\hline & & $\begin{array}{l}\text { Freedman et al., } \\
\text { Neurology 2011, } \\
\text { phase III } \\
\text { (MAESTRO study) }\end{array}$ & SPMS (n=612) & $\begin{array}{l}\text { MBP8298 500mg } \\
\text { IV/6 months: - } \\
0.28 ; \\
\text { Placebo: }-0.46, \\
p=0.137\end{array}$ & 24 months \\
\hline & & $\begin{array}{l}\text { Zajicek et al., } \\
\text { Lancet Neurol } \\
\text { 2013, phase } \\
\text { unspecified } \\
\text { (CUPID study) }\end{array}$ & $\begin{array}{l}\text { PPMS }(n=191) \text {, } \\
\text { SPMS }(n=302) \\
\text { (randomised: } \\
n=498)\end{array}$ & $\begin{array}{l}\text { Dronabinol [max. } \\
\text { dose: } 28 \mathrm{mg} / \text { day, } \\
\text { titrated against } \\
\text { bodyweight]: } \\
\text { yearly change - } \\
0 \cdot 17 \text { (SD } 0 \cdot 28 \text { ); } \\
\text { Placebo: yearly } \\
\text { change }-0 \cdot 16 \text { (SD } \\
0 \cdot 30), p=0.72\end{array}$ & 36 months \\
\hline \multirow[t]{3}{*}{ RFSS } & $\begin{array}{l}\text { Change from } \\
\text { baseline to FU }\end{array}$ & $\begin{array}{l}\text { Andersen et al., } \\
\text { JNNP 2004, phase } \\
\text { III (The Nordic } \\
\text { SPMS study) }\end{array}$ & SPMS (n=371) & $\begin{array}{l}\text { IFN beta-1a SC } \\
22 \mathrm{mcg} / \text { week vs. } \\
\text { placebo: no } \\
\text { differences (not } \\
\text { specified) }\end{array}$ & 36 months \\
\hline & $\begin{array}{l}\text { Time to an } \\
\text { increase } \geq 2 \% \text { in } \\
\text { RFSS score }\end{array}$ & $\begin{array}{l}\text { Andersen et al., } \\
\text { JNNP 2004, phase } \\
\text { III (The Nordic } \\
\text { SPMS study) }\end{array}$ & SPMS (n=371) & $\begin{array}{l}\text { IFN beta-1a SC } \\
22 \mathrm{mcg} / \text { week vs. } \\
\text { placebo: } \\
\text { HR }(95 \% \mathrm{Cl}) 0.93 \\
(0.68 \text { to } 1.28) \\
p=0.67\end{array}$ & 36 months \\
\hline & $\begin{array}{l}\% \text { patients with } \\
\text { an increase } \geq 2 \%\end{array}$ & $\begin{array}{l}\text { Andersen et al., } \\
\text { JNNP 2004, phase } \\
\text { III (The Nordic } \\
\text { SPMS study) }\end{array}$ & SPMS $(n=371)$ & $\begin{array}{l}\text { IFN beta-1a SC } \\
22 \mathrm{mcg} / \text { week: } \\
44 \% ; \\
\text { Placebo: } 44 \%, \\
p=0.45\end{array}$ & 36 months \\
\hline Ambulation index & $\begin{array}{l}\text { Change from } \\
\text { baseline to FU }\end{array}$ & $\begin{array}{l}\text { Andersen et al., } \\
\text { JNNP 2004, phase } \\
\text { III (Nordic SPMS } \\
\text { study) }\end{array}$ & SPMS (n=371) & $\begin{array}{l}\text { IFN beta-1a SC } \\
22 \text { mcg/week vs. } \\
\text { placebo: no } \\
\text { differences (not } \\
\text { specified) }\end{array}$ & 36 months \\
\hline Arm index & $\begin{array}{l}\text { Change from } \\
\text { baseline to FU }\end{array}$ & $\begin{array}{l}\text { Andersen et al., } \\
\text { JNNP 2004, phase } \\
\text { III (The Nordic } \\
\text { SPMS study) }\end{array}$ & SPMS ( $n=371)$ & $\begin{array}{l}\text { IFN beta-1a SC } \\
22 \mathrm{mcg} / \text { week vs. } \\
\text { placebo: no } \\
\text { differences (not } \\
\text { specified) }\end{array}$ & 36 months \\
\hline $\begin{array}{l}\text { Rao's Brief } \\
\text { Repeatable } \\
\text { Battery }\end{array}$ & $\begin{array}{l}\text { \% patients with } \\
\text { change in } \\
\text { cognitive } \\
\text { impairment (c) }\end{array}$ & $\begin{array}{l}\text { North American } \\
\text { Study Group on } \\
\text { IFN beta-1b in } \\
\text { SPMS, Neurology } \\
\text { 2004, phase III }\end{array}$ & SPMS (n=939) & $\begin{array}{l}\text { Pooled IFN beta- } \\
1 \mathrm{~b}(250 \mathrm{mcg} \text { SC } \\
\text { eod or } \\
160 \mathrm{mcg} / \mathrm{m} 2 \mathrm{SC} \\
\text { eod) vs. placebo: }\end{array}$ & $\begin{array}{l}\text { Early termination } \\
\text { for futility } \\
\text { (initially planned: } \\
36 \text { months) }\end{array}$ \\
\hline
\end{tabular}




\begin{tabular}{|c|c|c|c|c|c|}
\hline & & (NASPMS study) & & $\begin{array}{l}\text { no difference (not } \\
\text { specified) }\end{array}$ & \\
\hline \multirow[t]{4}{*}{$\begin{array}{l}\text { Composite } \\
\text { progressive } \\
\text { disability score }\end{array}$} & $\begin{array}{l}\text { Time to CDP, } \\
\text { defined as } \\
\text { presence of at } \\
\text { least } 1 \text { out of the } \\
3 \text { : } \\
- \text { Increase in EDSS } \\
(0.5 \text { if EDSS } \leq 5.5 ; \\
1.0 \text { if EDSS }>6.0) \\
- \text { Increase in } \geq 20 \% \\
\text { in } 9 \text { HPT } \\
- \text {-Increase } \geq 20 \% \text { in } \\
\text { TWT }\end{array}$ & $\begin{array}{l}\text { Lublin et al., } \\
\text { Lancet } 2016 \\
\text { (INFORMS study) }\end{array}$ & PPMS (n=970) & $\begin{array}{l}\text { Fingolimod 0.5mg } \\
\text { PO/day: 62.9\% } \\
\text { (57.10-68.62); } \\
\text { Placebo: 70.0\% } \\
\text { (61.78-78.21), } \\
\text { p>0.05 }\end{array}$ & 36 months \\
\hline & $\begin{array}{l}\% \text { patients with } \\
\text { at least one of } \\
\text { the three } \\
\text { situations } \\
\text { (confirmed at } \\
3 \mathrm{~m}): \\
\text {-Increase in EDSS } \\
(0.5 \text { if EDSS } \leq 5.5 ; \\
1.0 \text { if EDSS }>6.0) \\
\text {-Increase in } \geq 20 \% \\
\text { in } 9 \text { HPT } \\
\text {-Increase } \geq 20 \% \text { in } \\
\text { TWT }\end{array}$ & $\begin{array}{l}\text { Lublin et al., } \\
\text { Lancet } 2016 \\
\text { (INFORMS study) }\end{array}$ & PPMS (n=970) & $\begin{array}{l}\text { Fingolimod 0.5mg } \\
\text { PO/day: } 62.9 \% \\
\text { (57.10-68.62); } \\
\text { Placebo: 70.0\% } \\
(61.78-78.21) \\
p>0.05\end{array}$ & 36 months \\
\hline & $\begin{array}{l}\text { Time to 3-month } \\
\text { CDP, using EDSS } \\
\text { or } 9 \text { HPT (q) }\end{array}$ & $\begin{array}{l}\text { Hommes et al., } \\
\text { Lancet 2004, } \\
\text { phase III, (ESIMS } \\
\text { study) }\end{array}$ & SPMS (n=318) & $\begin{array}{l}\text { IVIG } 1 \mathrm{~g} / \mathrm{Kg} / \text { month } \\
\text { Vs. placebo: HR } \\
(95 \% \mathrm{Cl}) 1.12 \\
(0.84 \text { to } 1.49) \\
p=0.44\end{array}$ & 24 months \\
\hline & $\begin{array}{l}\text { \% of patients } \\
\text { with 3-month } \\
\text { CDP, using EDSS } \\
\text { or 9HPT (q) }\end{array}$ & $\begin{array}{l}\text { Hommes et al., } \\
\text { Lancet 2004, } \\
\text { phase III, (ESIMS } \\
\text { study) }\end{array}$ & SPMS $(n=318)$ & $\begin{array}{l}\text { Placebo: } 57.9 \% \\
\text { IVIG } 1 \mathrm{~g} / \mathrm{Kg} / \mathrm{month} \\
\text { vs. placebo: } \\
61.6 \%, p=0.44\end{array}$ & 24 months \\
\hline $\begin{array}{l}\text { Multiple Sclerosis } \\
\text { Walking Scale } \\
\text { (MSWS-12) }\end{array}$ & $\begin{array}{l}\text { Change from } \\
\text { baseline to FU }\end{array}$ & $\begin{array}{l}\text { Zajicek et al., } \\
\text { Lancet Neurol } \\
\text { 2013, phase } \\
\text { unspecified } \\
\text { (CUPID study) }\end{array}$ & $\begin{array}{l}\text { PPMS }(n=191) \\
\text { SPMS }(n=302) \\
\text { (received } \\
\text { treatment: } n=493 ; \\
\text { randomised: } \\
n=498 \text { ) }\end{array}$ & $\begin{array}{l}\text { Dronabinol [max. } \\
\text { dose: } 28 \mathrm{mg} / \mathrm{day} \text {, } \\
\text { titrated against } \\
\text { bodyweight]: } \\
\text { yearly change } \\
0.37 \text { (SD } 2.33) ; \\
\text { Placebo: yearly } \\
\text { change } 0.52 \\
(2.68) ; p=0.74\end{array}$ & 36 months \\
\hline MSIS-29 & $\begin{array}{l}\text { Change from } \\
\text { baseline to FU } \\
\text { (physical score) }\end{array}$ & $\begin{array}{l}\text { Zajicek et al., } \\
\text { Lancet Neurol } \\
\text { 2013, phase } \\
\text { unspecified } \\
\text { (CUPID study) }\end{array}$ & $\begin{array}{l}\text { PPMS }(n=191) \\
\text { SPMS }(n=302) \\
\text { (received } \\
\text { treatment: } n=493 ; \\
\text { randomised: } \\
n=498 \text { ) }\end{array}$ & $\begin{array}{l}\text { Dronabinol [max. } \\
\text { dose: } 28 \mathrm{mg} / \text { day, } \\
\text { titrated against } \\
\text { bodyweight]: } \\
\text { yearly change } \\
0.62 \text { (SD 3.29); } \\
\text { Placebo: yearly } \\
\text { change } 1.03 \text { (SD }\end{array}$ & 36 months \\
\hline
\end{tabular}


Table footnote:

(a) ARR refers to mean ARR per each group; it includes confirmed relapse rate, which includes rate of relapses with confirmed increase in EDSS (Voskuhl et al., Lancet Neurol 2016) and also adjusted mean relapse rate (Vollmer et al., J Neurol 2014)

(b) No detailed figures provided

(c) Cognitive impairment was defined on the number of failed tests, as mild (one to two tests failed) or moderate-severe (three or more tests failed)

(d) Defined as $\geq 7.5$ points increase in MSIS-29

(e) CDP: Confirmed disability progression was defined as an increase of Expanded Disability Status Scale score of at least 1.0 point for patients with a baseline score of 1.0 or more, or an increase of at least 1.5 points for patients with a baseline score of 0 , confirmed after 12 weeks. For the rest, EDSS increase of $\geq 1$ point if EDSS $\leq 5.5$; EDSS increase of $\geq 0.5$ point if EDSS $>5.5$;

(f) Includes adjusted MSFC z-score; also it may include values obtained at an early termination time point if this occurred after 12 months.

(g) Includes time to sustained accumulation of disability, which is considered as increase in 1 point in EDSS sustained for a minimum of 12 weeks (Confavreux et al., Lancet Neurol 2014, TOWER trial)

(h) No MRI activity includes: no new/enlarging lesions and no gadolinium-enhancing lesions

(i) Includes relapses requiring hospitalization/IV steroids (Comi et al., NEJM 2012, ALLEGRO study)

(j) Adjusting for baseline values of MSFC z-score, ANCOVA model

(k) Mean change reported, unless otherwise specified

(I) It includes 'at least 1 major relapse'

(m) The authors also estimated the proportion of patients with: i) at least one MSrelated admission to hospital; ii) at least 1 MS-rekated steroid course

(n) The results shown refer to the comparative phase $(0-12 \mathrm{~m})$ of the trial, where half of the patients were receiving IFN beta-1a IM $30 \mathrm{mcg} /$ week and the other half IFN beta-1a SC $44 \mathrm{mcg}$ tiw.

(o) p-value not specified

(p) this analysis refers to disability progression in both hands

(q) worsening in 9HPT is defined as deterioration greater or equal to $20 \%$

(r) confirmed at 2 months

(s) mean number of relapses per patient during the trial/2 years (duration of trial)

(t) defined as 2-step increase (sustained for 3 months)

(u) in this context, this outcome measure (risk ratio or odds ratio) is equivalent to hazard ratio in the survival model

(v) timing for CDP not specified. Assumed 3 months

(w) this study looked at disability progression at the end of FU, so it is possible that just progression confirmed at just 3 months is also included here

(x) This refers to McDonald 2005 criteria 
Abbreviations. BD: twice per day; CDP: confirmed disability progression; $\mathrm{Cl}$ : confidence interval; eod: every other day; FU: follow-up; GA: glatiramer acetate; HR: hazard ratio; IA \& AHSCT: immunoablation and autologous haemopoietic stem-cell transplantation; IFN: interferon; IQR: interquartile range; MIU: million international units; MSCT: mesenchymal stem cell transplantation; MSFC: Multiple Sclerosis Functional Composite; MSIS-29: Multiple Sclerosis Impact Scale - 29 items; PO: per oral; RFSS: Regional Functional System Score; SC: subcutaneous; SF-36: Short Form 36 Health Survey (SF-36); SNRS: Scripps Neurological Rating Scale; TDS: three times per day; tiw: three times in a week; TSQM: Treatment Satisfaction Questionnaire for Medication, with domains for Effectiveness, Side-Effects, Convenience and Global Satisfaction 
Table 4: Brain MRI outcome measures in phase III trials in relapsing-remitting MS

\section{Brain MRI}

Inclusion criteria: controlled phase III clinical trials

Exclusion criteria: incomplete data presentation (e.g. missing values); descriptive findings in absence of any statistical analysis; secondary analyses of clinical trials and extension studies evaluating the same clinical endpoints of the main trial in population subgroups or during longer observation time.

\begin{tabular}{|c|c|c|c|c|c|}
\hline $\begin{array}{l}\text { Original } \\
\text { neuroimaging } \\
\text { outcome }\end{array}$ & $\begin{array}{l}\text { Derived } \\
\text { outcome } \\
\text { measures }\end{array}$ & Trial & \begin{tabular}{|l|} 
Condition \\
(no. of \\
patients \\
randomised)
\end{tabular} & $\begin{array}{l}\text { Drug, effect } \\
\text { (vs. placebo/ another } \\
\text { active arm) }\end{array}$ & $\begin{array}{l}\text { Duration of } \\
\text { the trial }\end{array}$ \\
\hline \multirow[t]{7}{*}{ T2 lesions } & $\begin{array}{l}\text { Number of } \\
\text { new lesions }\end{array}$ & $\begin{array}{l}\text { The Interferon beta } \\
\text { Multiple Sclerosis } \\
\text { Study group; Paty et } \\
\text { al., Neurology } 1993 \\
\text { (Interferon beta } \\
\text { Multiple Sclerosis } \\
\text { Study Group) }\end{array}$ & $\begin{array}{l}\text { RRMS } \\
(n=372)\end{array}$ & $\begin{array}{l}\text { Interferon beta- } 1 \text { b vs. } \\
\text { Placebo, median new } \\
\text { lesion rate } 0.5 \text { vs. } 2.0 \\
(p=0.0026)\end{array}$ & 24 months \\
\hline & & $\begin{array}{l}\text { Comi et al., Ann } \\
\text { Neurol 2001 } \\
\text { (European/Canadian } \\
\text { Glatiramer Acetate } \\
\text { Study) }\end{array}$ & $\begin{array}{l}\text { RRMS } \\
(n=249)\end{array}$ & $\begin{array}{l}\text { Glatiramer Acetate vs. } \\
\text { Placebo, number of } \\
\text { lesions } 9.4 \text { vs. } 13.7 \\
(p<0.003) \text { after } 9 \text { months }\end{array}$ & 9 months \\
\hline & & $\begin{array}{l}\text { Polman et al., New } \\
\text { Eng J Neurol 2006; } \\
\text { Miller et al., } \\
\text { Neurology } 2007 \\
\text { (AFFIRM study) }\end{array}$ & $\begin{array}{l}\text { RRMS } \\
(n=627)\end{array}$ & $\begin{array}{l}\text { Natalizumab vs. Placebo, } \\
\text { number of lesions } 1.1 \text { vs. } \\
5.8 \text { after } 1 \text { year } \\
\text { ( } p<0.001), 0.7 \text { vs. } 4.4 \\
\text { after } 2 \text { years }(p<0.001), \\
\text { and } 1.8 \text { vs. } 10.2 \text { overall } \\
(p<0.001)\end{array}$ & 24 months \\
\hline & & $\begin{array}{l}\text { O'Connor et al., } \\
\text { Lancet Neurol } 2009 \\
\text { (BEYOND study) }\end{array}$ & $\begin{array}{l}\text { RRMS } \\
(n=2244)\end{array}$ & $\begin{array}{l}\text { Interferon beta-1a } 500 \mu \mathrm{g} \\
\text { vs. } 250 \mu \mathrm{g} \text { vs. Glatiramer } \\
\text { acetate, number of } \\
\text { lesions } 3.3 \text { vs. } 3.3 \text { vs. } 4.6 \\
\text { after } 2 \text { years ( } p=0.25 ; \\
p=0.0009 ; p=0.011)\end{array}$ & 24 months \\
\hline & & $\begin{array}{l}\text { Comi et al., Ann } \\
\text { Neurol } 2011 \\
\text { (FORTE study) }\end{array}$ & $\begin{array}{l}\text { RRMS } \\
(n=980)\end{array}$ & $\begin{array}{l}\text { Glatiramer Acetate } 20 \mathrm{mg} \\
\text { vs. } 40 \mathrm{mg} \text {, number of } \\
\text { lesions } 2.87 \text { vs. } 2.72 \text { (ns) } \\
\text { after } 12 \text { months }\end{array}$ & 12 months \\
\hline & $\begin{array}{l}\text { Number of } \\
\text { enlarging } \\
\text { lesions }\end{array}$ & $\begin{array}{l}\text { Polman et al., New } \\
\text { Eng J Neurol 2006; } \\
\text { Miller et al., } \\
\text { Neurology } 2007 \\
\text { (AFFIRM study) }\end{array}$ & $\begin{array}{l}\text { RRMS } \\
(n=627)\end{array}$ & $\begin{array}{l}\text { Natalizumab vs. Placebo, } \\
\text { number of lesions } 0.1 \text { vs. } \\
0.4 \text { after } 1 \text { year } \\
(p<0.001), 0.0 \text { vs. } 0.4 \\
\text { after } 2 \text { years }(p<0.001), \\
\text { and } 0.1 \text { vs. } 0.8 \text { overall } \\
(p<0.001)\end{array}$ & 24 months \\
\hline & $\begin{array}{l}\text { Number of } \\
\text { new or } \\
\text { enlarging } \\
\text { lesions }\end{array}$ & $\begin{array}{l}\text { PRISMS Study } \\
\text { Group, Lancet 1998; } \\
\text { Li et al., Ann Neurol } \\
1999 \\
\text { (PRISMS study) }\end{array}$ & $\begin{array}{l}\text { RRMS } \\
(n=560)\end{array}$ & $\begin{array}{l}\text { Interferon beta-1a } 44 \mu \mathrm{g} \\
\text { vs. } 22 \mu \mathrm{g} \text { vs. Placebo, } \\
\text { percent difference } \\
\text { compared to Placebo - } \\
67 \% \text { and }-78 \% \text { ( }<<0.0001) \\
\text { after } 2 \text { years; median } \\
\text { number of lesions per } \\
\text { patient per scan } 0.5 \text { vs. - }\end{array}$ & 24 months \\
\hline
\end{tabular}




\begin{tabular}{|c|c|c|c|c|c|}
\hline & & & & $\begin{array}{l}0.75 \text { vs. } 2.25 \text { ( } p=0.0003 ; \\
p<0.0001 ; p<0.0001) \text { after } \\
6 \text { months; percent of } \\
\text { scans with lesions } 25 \% \text { vs. } \\
50 \% \text { vs. } 75 \% \text { ( } p=0.0002 ; \\
p<0.0001 ; p<0.0001) \text { after } \\
6 \text { months; and percent of } \\
\text { patients without lesions } \\
31 \% \text { vs. } 19 \% \text { vs. } 8 \% \\
\text { ( } p=0.0009 ; p<0.0001 ; \\
p<0.0001) \text { after } 6 \text { months }\end{array}$ & \\
\hline & & $\begin{array}{l}\text { Jacobs et al., New } \\
\text { Eng J Med } 2000 \\
\text { (CHAMPS study) }\end{array}$ & CIS $(n=383)$ & $\begin{array}{l}\text { Interferon beta- } 1 \mathrm{a} 30 \mu \mathrm{g} \\
\text { vs. Placebo, number of } \\
\text { lesions } 1.5 \text { vs. } 2.8 \text { after } 6 \\
\text { months ( } p=0.01), 2.1 \text { vs. } \\
4.0 \text { after } 12 \text { months } \\
(p<0.001), 2.1 \text { vs. } 5.0 \text { after } \\
18 \text { months ( } p<0.001)\end{array}$ & $\begin{array}{l}\text { Early } \\
\text { termination: } \\
\text { obvious } \\
\text { superiority } \\
\text { of IFNb over } \\
\text { placebo } \\
\text { (initially } \\
\text { planned: } 36 \\
\text { months) }\end{array}$ \\
\hline & & $\begin{array}{l}\text { Comi et al., Lancet } \\
2001 \\
\text { (ETOMS study) }\end{array}$ & CIS $(n=309)$ & $\begin{array}{l}\text { Interferon beta-1a } 22 \mu \mathrm{g} \\
\text { vs. Placebo, median } \\
\text { number of lesions per } \\
\text { patient per scan } 2.0 \text { vs. } \\
3.0 \text { after } 2 \text { years } \\
(p<0.001)\end{array}$ & 24 months \\
\hline & & $\begin{array}{l}\text { Panitch et al., } \\
\text { Neurology 2002; } \\
\text { Panitch et al., J } \\
\text { Neurol Sci. 2005 } \\
\text { (EVIDENCE study) }\end{array}$ & $\begin{array}{l}\text { RRMS } \\
(n=677)\end{array}$ & $\begin{array}{l}\text { Interferon beta- } 1 \mathrm{a} 44 \mu \mathrm{g} \\
\text { vs. } 30 \mu \mathrm{g}, \text { number of } \\
\text { lesions } 0.9 \text { vs. } 1.4 \\
(p<0.001), \text { percent of } \\
\text { scans with lesions } 27 \% \text { vs. } \\
44 \% \text { ( } p<0.001), \text { percent of } \\
\text { patients with no lesions } \\
\begin{array}{l}58 \% \text { vs. } 38 \% \text { ( } p<0.001) \\
\text { after } 16 \text { months }\end{array} \\
\end{array}$ & $\begin{array}{l}24 \text { months } \\
\text { (0-12m: } \\
\text { comparative } \\
\text { phase; } 12- \\
24 \mathrm{~m} \text { : cross- } \\
\text { over phase) }\end{array}$ \\
\hline & & $\begin{array}{l}\text { Polman et al., New } \\
\text { Eng J Neurol } 2006 \\
\text { Miller et al., } \\
\text { Neurology } 2007 \\
\text { (AFFIRM study) }\end{array}$ & $\begin{array}{l}\text { RRMS } \\
(n=627)\end{array}$ & $\begin{array}{l}\text { Natalizumab vs. Placebo, } \\
\text { number of lesions } 1.2 \text { vs. } \\
6.1 \text { after } 1 \text { year } \\
(p<0.001), 0.7 \text { vs. } 4.9 \\
\text { after } 2 \text { years }(p<0.001), \\
\text { and } 1.9 \text { vs. } 11.0 \text { overall } \\
(p<0.001)\end{array}$ & 24 months \\
\hline & & $\begin{array}{l}\text { Rudick et al., New } \\
\text { Eng J Med } 2006 \\
\text { (SENTINEL study) }\end{array}$ & $\begin{array}{l}\text { RRMS } \\
(n=1171)\end{array}$ & $\begin{array}{l}\text { Natalizumab+Interferon } \\
\text { beta-1a vs. Interferon } \\
\text { beta-1a, number of } \\
\text { lesions } 0.9 \text { vs. } 5.4 \text { after } 2 \\
\text { years }(p<0.001)\end{array}$ & 24 months \\
\hline & & $\begin{array}{l}\text { Mikol et al., Lancet } \\
\text { Neurol } 2008 \\
\text { (REGARD study) }\end{array}$ & $\begin{array}{l}\text { RRMS } \\
(n=764)\end{array}$ & $\begin{array}{l}\text { Interferon beta- } 1^{\text {a }} 44 \mu \mathrm{g} \\
\text { vs. Glatiramer acetate } 20 \\
\text { mg, lesions per patient } \\
\text { per scan } 0.67 \text { vs. } 0.82 \\
\text { after } 96 \text { weeks ( } p=0.18 \text { ); } \\
\text { proportion of scans per } \\
\text { patient with lesions } \\
24.6 \% \text { vs. } 26.3 \% \text { after } 96 \\
\text { weeks }(p=0.34) ; \text { patients }\end{array}$ & 96 weeks \\
\hline
\end{tabular}




\begin{tabular}{|c|c|c|c|c|c|}
\hline & & & & $\begin{array}{l}\text { with no lesions } 40 \% \text { vs. } \\
37 \% \text { after } 96 \text { weeks } \\
(p=0.51)\end{array}$ & \\
\hline & & $\begin{array}{l}\text { Cohen et al., New } \\
\text { Eng J Med } 2010 \\
\text { (TRANSFORMS } \\
\text { study) }\end{array}$ & $\begin{array}{l}\text { RRMS } \\
(n=1292)\end{array}$ & $\begin{array}{l}\text { Fingolimod } 1.25 \mathrm{mg} \text { and } \\
0.5 \mathrm{mg} \text { vs. Interferon beta- } \\
1 \mathrm{a}(30 \mu \mathrm{\mu g} / \text { week), number } \\
\text { of lesions } 1.5(\mathrm{p}<0.001) \\
\text { and } 1.7 \text { ( } \mathrm{p}=0.004), \text { vs. } 2.6 \\
\text { after } 12 \text { months; percent } \\
\text { of patients free of lesions } \\
48.0 \%(p=0.37) \text { and } 54.8 \% \\
\text { ( } p=0.01), \text { vs. } 45.7 \% \text { after } \\
12 \text { months }\end{array}$ & 12 months \\
\hline & & $\begin{array}{l}\text { Kappos et al., New } \\
\text { Eng J Med 2010; } \\
\text { Radue et al., Arch } \\
\text { Neurol } 2012 \\
\text { (FREEDOMS study) }\end{array}$ & $\begin{array}{l}\text { RRMS } \\
(n=1272)\end{array}$ & 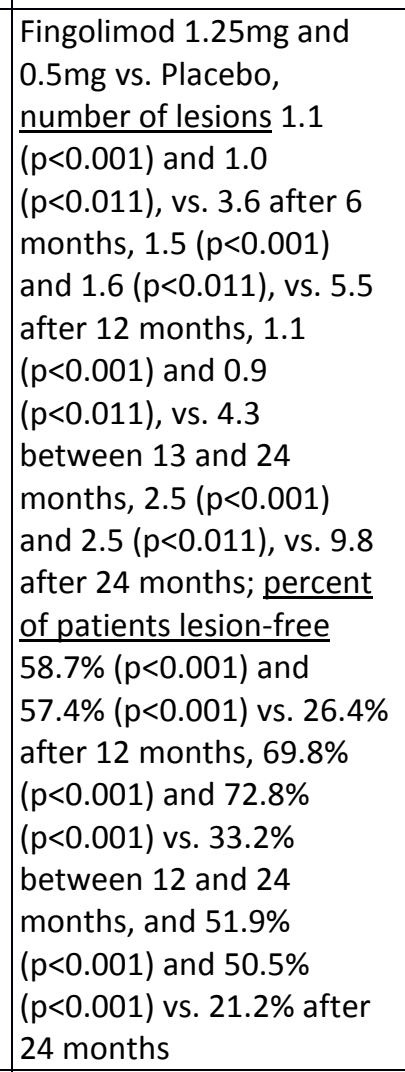 & 24 months \\
\hline & & $\begin{array}{l}\text { Giovannoni et al., } \\
\text { Lancet Neurol 2011; } \\
\text { Comi et al., J Neurol } \\
2013 \\
\text { (CLARITY study) }\end{array}$ & $\begin{array}{l}\text { RRMS } \\
(n=1326)\end{array}$ & \begin{tabular}{|l} 
Cladribine $3.5 \mathrm{mg} / \mathrm{kg}$ and \\
Cladribine $5.25 \mathrm{mg} / \mathrm{kg}$ vs. \\
Placebo, proportion of \\
patients lesion-free \\
$61.8 \%(p<0.001)$ and \\
$62.8 \%(p<0.001)$, vs. \\
$27.6 \%$ after 96 weeks; \\
relative reduction $73.4 \%$ \\
$(p<0.001)$ and $76.9 \%$ \\
$(p<0.001)$ after 96 weeks
\end{tabular} & 96 weeks \\
\hline & & $\begin{array}{l}\text { O'Connor et al., New } \\
\text { Eng J Med 2011; } \\
\text { Wolinsky et al., Mult } \\
\text { Scler } 2013 \\
\text { (TEMSO study) }\end{array}$ & RMS (1088) & $\begin{array}{l}\text { Teriflunomide } 14 \mathrm{mg} \text { and } \\
7 \mathrm{mg} \text { vs. Placebo, mean } \\
\text { difference from Placebo - } \\
0.089(p=0.0003) \text { and - } \\
0.053(p=0.0317) \text { after } \\
108 \text { weeks }\end{array}$ & 108 weeks \\
\hline & & \begin{tabular}{|l} 
Sorensen et al., \\
Lancet Neurol 2011
\end{tabular} & $\begin{array}{l}\text { RRMS } \\
(n=307)\end{array}$ & $\begin{array}{l}\text { Interferon beta-1a } 30 \mu \mathrm{g} \\
\text { with vs. without }\end{array}$ & 12 months \\
\hline
\end{tabular}




\begin{tabular}{|c|c|c|c|c|c|}
\hline & & (SIMCOMBIN study) & & $\begin{array}{l}\text { Simvastatin } 80 \mathrm{mg}, \text { mean } \\
\text { number of lesions } 2.96 \mathrm{vs} . \\
2.52 \text { after } 12 \text { months }(\mathrm{ns})\end{array}$ & \\
\hline & & $\begin{array}{l}\text { Cohen et al., Lancet } \\
2012 \\
\text { (CARE-MS I) }\end{array}$ & $\begin{array}{l}\text { RRMS } \\
(n=581)\end{array}$ & $\begin{array}{l}\text { Alemtuzumab } 12 \mathrm{mg} \text { vs. } \\
\text { Interferon beta-1a } 44 \mu \mathrm{g}, \\
\text { proportion of patients } \\
\text { with lesions } 48 \% \text { vs. } 58 \% \\
\text { after } 2 \text { years }(\mathrm{p}=0.04 \text { ) }\end{array}$ & 24 months \\
\hline & & $\begin{array}{l}\text { Coles et al., Lancet } \\
2012 \\
\text { (CARE-MS II) }\end{array}$ & $\begin{array}{l}\text { RRMS } \\
(n=840)\end{array}$ & $\begin{array}{l}\text { Alemtuzumab } 12 \mathrm{mg} \text { vs. } \\
\text { Interferon beta- } 1 \mathrm{a} 44 \mu \mathrm{g}, \\
\text { proportion of patients } \\
\text { with lesions } 46 \% \text { vs. } 68 \% \\
\text { after } 2 \text { years }(p<0.0001 \text { ) } \\
\end{array}$ & 24 months \\
\hline & & $\begin{array}{l}\text { Comi et al., New Eng } \\
\text { J Med. } 2012 \\
\text { (ALLEGRO study) }\end{array}$ & $\begin{array}{l}\text { RRMS } \\
(n=1106)\end{array}$ & $\begin{array}{l}\text { Laquinimod vs. Placebo, } \\
\text { cumulative number of } \\
\text { lesions } 5.03 \text { vs. } 7.14 \\
\begin{array}{l}(p<0.001) \text { at } 12 \text { and } 24 \\
\text { months }\end{array}\end{array}$ & 24 months \\
\hline & & $\begin{array}{l}\text { Fox et al., New Eng J } \\
\text { Med. } 2012 \\
\text { (CONFIRM study) }\end{array}$ & \begin{tabular}{|l|} 
RRMS \\
( $n=682$, MRI \\
cohort)
\end{tabular} & $\begin{array}{l}\text { Dimethyl Fumarate } \\
240 m g \text { BID or TID or } \\
\text { Glatiramer acetate vs. } \\
\text { Placebo, number of } \\
\text { lesions } 5.1(p<0.001), 4.7 \\
(p<0.001), 8.0(p<0.001) \\
\text { vs. } 17.4 \text { after } 2 \text { years } \\
\end{array}$ & 24 months \\
\hline & & $\begin{array}{l}\text { Gold et al., New Eng } \\
\text { J Med 2012; Arnold } \\
\text { et al., J Neurol } 2014 \\
\text { (DEFINE study) }\end{array}$ & $\begin{array}{l}\text { RRMS } \\
(n=1234)\end{array}$ & $\begin{array}{l}\text { Dimethyl Fumarate } \\
240 \mathrm{mg} \text { BID and TID vs. } \\
\text { Placebo, number of } \\
\text { lesions } 2.6(p=0.01) \text { and } \\
4.4(p=0.01) \text { vs. } 17.6 \text { after } \\
96 \text { weeks; in a sub-cohort } \\
\text { of } 540 \text { patients, } 1.1 \\
(p<0.0001) \text { and } 1.6 \\
(p<0.0001) \text { vs. } 5.2 \text { after } 6 \\
\text { months, } 1.6(p<0.0001) \\
\text { and } 2.6(p<0.0001) \text { vs. } \\
10.3 \text { after } 1 \text { year, and } 2.6 \\
(p<0.0001) \text { and } 4.4 \\
(p<0.0001) \text { vs. } 17.0 \text { after } 2 \\
\text { years }\end{array}$ & 24 months \\
\hline & & $\begin{array}{l}\text { Khan et al., Ann } \\
\text { Neurol 2013; } \\
\text { Zivadinov et al., J } \\
\text { Neurol } 2015 \\
\text { (GALA study) }\end{array}$ & $\begin{array}{l}\text { RRMS } \\
(n=1404)\end{array}$ & $\begin{array}{l}\text { Glatiramer acetate } 40 \mathrm{mg} \\
\text { vs. Placebo, cumulative } \\
\text { number of lesions } 3.650 \\
\begin{array}{l}\text { vs. } 5.592 \text { after } 6 \text { and } 12 \\
\text { months }(p<0.0001)\end{array} \\
\end{array}$ & 12 months \\
\hline & & $\begin{array}{l}\text { Calabresi et al., } \\
\text { Lancet Neurol 2014; } \\
\text { Arnold et al., BMC } \\
\text { Neurol } 2014 \\
\text { (ADVANCE study) }\end{array}$ & $\begin{array}{l}\text { RRMS } \\
(n=1512)\end{array}$ & $\begin{array}{l}\text { Peginterferon beta- } 1 a \\
\text { every } 4 \text { vs. } 2 \text { weeks vs. } \\
\text { Placebo, number of } \\
\text { lesions } 4.6 \text { vs. } 2.2 \text { vs. } 5.8 \\
\text { ( } p<0.0001 ; p<0.0001 ; \\
p=0.023) \text { after } 24 \text { weeks, } \\
\text { and } 7.9 \text { vs. } 3.6 \text { vs. } 10.9 \\
(p<0.0001 ; p<0.0001 ; \\
p=0.0008) \text { after } 48 \text { weeks }\end{array}$ & 24 months \\
\hline & & $\begin{array}{l}\text { Calabresi et al., } \\
\text { Lancet Neurol } 2014\end{array}$ & $\begin{array}{l}\text { RRMS } \\
(n=1083)\end{array}$ & $\begin{array}{l}\text { Fingolimod } 1.25 \mathrm{mg} \text { and } \\
0.5 \mathrm{mg} \text { vs. Placebo, }\end{array}$ & 24 months \\
\hline
\end{tabular}




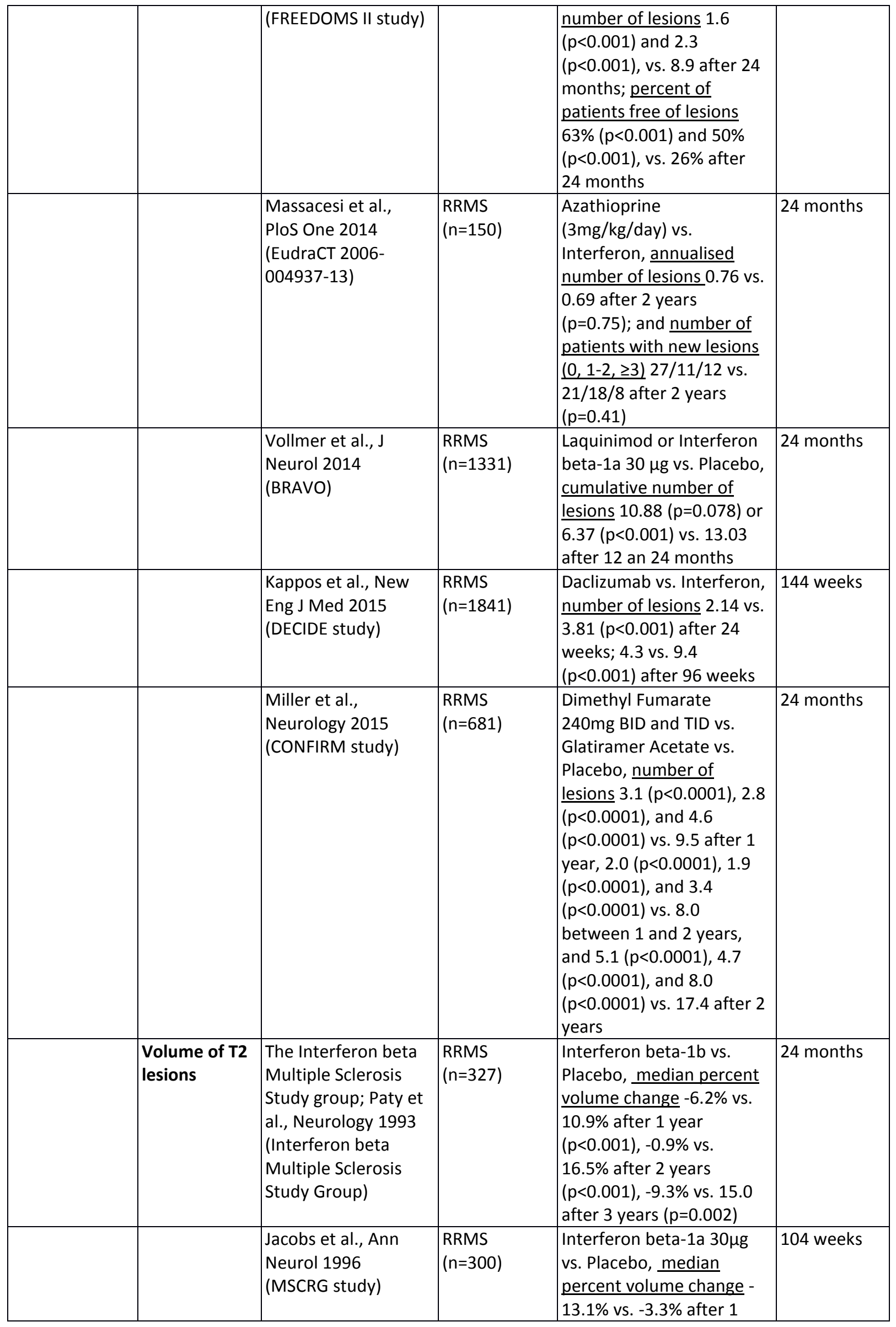




\begin{tabular}{|c|c|c|c|c|c|}
\hline & & & & $\begin{array}{l}\text { year }(P=0.02) \text {, and }-13.2 \% \\
\text { vs. }-6.5 \% \text { after } 2 \text { years } \\
(p=0.36)\end{array}$ & \\
\hline & & $\begin{array}{l}\text { PRISMS Study } \\
\text { Group, Lancet 1998; } \\
\text { Li et al., Ann Neurol } \\
1999 \\
\text { (PRISMS study) }\end{array}$ & $\begin{array}{l}\text { RRMS } \\
(n=533)\end{array}$ & $\begin{array}{l}\text { Interferon beta-1a } 44 \mu \mathrm{g} \\
\text { vs. } 22 \mu \mathrm{g} \text { vs. Placebo, } \\
\text { median percent volume } \\
\text { change }-4.2 \% \text { vs. }-1.5 \% \text { vs. } \\
4.0 \% \text { ( } p=0.0246 ; \\
p=0.0001 ; p=0.0001 \text { ) after } \\
6 \text { months, }-4.5 \% \text { vs. }-3.5 \% \\
\text { vs. } 6.4 \% \text { ( } p=0.3809 ; \\
p=0.0001 ; p=0.0001 \text { ) after } \\
12 \text { months, }-3.1 \% \text { vs. }- \\
1.4 \% \text { vs. } 10.8 \% \text { ( } p=0.0974 ; \\
p=0.0001 ; p=0.0001) \text { after } \\
18 \text { months, and }-3.8 \% \text { vs. } \\
-1.2 \% \text { vs. } 10.9 \% \\
(p=0.0537 ; p=0.0001 ; \\
p=0.0001) \text { after } 24 \\
\text { months }\end{array}$ & 24 months \\
\hline & & $\begin{array}{l}\text { Comi et al., Ann } \\
\text { Neurol } 2001 \\
\text { (European/Canadian } \\
\text { Glatiramer Acetate } \\
\text { Study) }\end{array}$ & $\begin{array}{l}\text { RRMS } \\
(n=249)\end{array}$ & $\begin{array}{l}\text { Glatiramer Acetate vs. } \\
\text { Placebo, volume change } \\
3.0 \mathrm{~mL} \text { vs. } 4.7 \mathrm{~mL}(\mathrm{p}=0.006) \\
\text { after } 9 \text { months }\end{array}$ & 9 months \\
\hline & & $\begin{array}{l}\text { Polman et al., New } \\
\text { Eng J Neurol 2006; } \\
\text { Miller et al., } \\
\text { Neurology } 2007 \\
\text { (AFFIRM study) }\end{array}$ & $\begin{array}{l}\text { RRMS } \\
(n=627)\end{array}$ & $\begin{array}{l}\text { Natalizumab vs. Placebo, } \\
\text { lesion volume } \\
14303.7 \mathrm{~mm}^{3} \text { vs. } \\
15703.2 \mathrm{~mm}^{3} \text { after } 1 \text { year } \\
(p=0.016), 14722.0 \mathrm{~mm}^{3} \\
\text { vs. } 17853.1 \mathrm{~mm}^{3} \text { lesions } \\
\text { after } 2 \text { years }(p<0.001), \\
\text { and } 14722.0 \mathrm{~mm}^{3} \text { vs. } \\
17853.0 \mathrm{~mm}^{3} \text { lesions } \\
\text { overall }(p<0.001)\end{array}$ & 24 months \\
\hline & & $\begin{array}{l}\text { Mikol et al., Lancet } \\
\text { Neurol } 2008 \\
\text { (REGARD study) }\end{array}$ & $\begin{array}{l}\text { RRMS } \\
(n=764)\end{array}$ & $\begin{array}{l}\text { Interferon beta- } 1^{\text {a }} 44 \mu \mathrm{g} \\
\text { vs. Glatiramer acetate } 20 \\
\text { mg, volume change - } \\
2416.9 \mathrm{~mm}^{3} \text { vs. - } \\
1583.5 \mathrm{~mm}^{3} \text { after } 96 \\
\text { weeks }(p=0.26)\end{array}$ & 96 weeks \\
\hline & & $\begin{array}{l}\text { O'Connor et al., } \\
\text { Lancet Neurol } 2009 \\
\text { (BEYOND study) }\end{array}$ & $\begin{array}{l}\text { RRMS } \\
(n=2244)\end{array}$ & $\begin{array}{l}\text { Interferon beta-1a } 500 \mu \mathrm{g} \\
\text { vs. } 250 \mu \mathrm{g} \text { vs. Glatiramer } \\
\text { acetate, percent volume } \\
\text { change } 22.0 \% \text { vs. } 19.0 \% \\
\text { vs. } 25.0 \% \text { after } 2 \text { years } \\
(p=0.56 ; p=0.0008 ; \\
p=0.0001)\end{array}$ & 24 months \\
\hline & & $\begin{array}{l}\text { Cohen et al., New } \\
\text { Eng J Med } 2010 \\
\text { (TRANSFORMS } \\
\text { study) }\end{array}$ & $\begin{array}{l}\text { RRMS } \\
(n=1292)\end{array}$ & $\begin{array}{l}\text { Fingolimod } 1.25 \mathrm{mg} \text { and } \\
0.5 \mathrm{mg} \text { vs. Interferon beta- } \\
1 \mathrm{a}(30 \mu \mathrm{g} / \text { week), percent } \\
\text { volume change } 6.7 \% \\
\text { ( } p=0.48) \text { and } 9.9 \% \\
(p=0.63), \text { vs. } 10.4 \% \text { after } \\
12 \text { months }\end{array}$ & 12 months \\
\hline & & Kappos et al., New & RRMS & Fingolimod $1.25 \mathrm{mg}$ and & 24 months \\
\hline
\end{tabular}




\begin{tabular}{|c|c|c|c|c|c|}
\hline & & $\begin{array}{l}\text { Eng J Med 2010; } \\
\text { Radue et al., Arch } \\
\text { Neurol } 2012 \\
\text { (FREEDOMS study) }\end{array}$ & $(n=1272)$ & $\begin{array}{l}0.5 \mathrm{mg} \text { vs. Placebo, } \\
\text { percent volume change } \\
2.7 \%(p<0.001) \text { and } 3.4 \% \\
(p<0.001), \text { vs. } 18.7 \% \text { after } \\
12 \text { months, } 1.6 \% \\
(p<0.001) \text { and } 10.6 \% \\
(p<0.001), \text { vs. } 33.8 \% \text { after } \\
24 \text { months }\end{array}$ & \\
\hline & & $\begin{array}{l}\text { Sorensen et al., } \\
\text { Lancet Neurol } 2011 \\
\text { (SIMCOMBIN study) }\end{array}$ & $\begin{array}{l}\text { RRMS } \\
(n=307)\end{array}$ & $\begin{array}{l}\text { Interferon beta- } 1^{\text {a }} 30 \mu \mathrm{g} \\
\text { with vs. without } \\
\text { Simvastatin } 80 \mathrm{mg} \text {, } \\
\text { volume change } 0.033 \mathrm{~mL} \\
\text { vs. } 0.095 \mathrm{~mL} \text { after } 12 \\
\text { months }(p=0.612)\end{array}$ & 12 months \\
\hline & & $\begin{array}{l}\text { O'Connor et al., New } \\
\text { Eng J Med 2011; } \\
\text { Wolinsky et al., Mult } \\
\text { Scler } 2013 \\
\text { (TEMSO study) }\end{array}$ & RMS (1088) & $\begin{array}{l}\text { Teriflunomide } 14 \mathrm{mg} \text { and } \\
7 \mathrm{mg} \text { vs. Placebo, volume } \\
\text { change } 0.39 \mathrm{~mL} \\
(\mathrm{p}<0.0001) \text { and } 0.81 \mathrm{~mL} \\
(\mathrm{p}=0.04) \text { vs. } 1.67 \mathrm{~mL} \text { after } \\
108 \text { weeks }\end{array}$ & 108 weeks \\
\hline & & $\begin{array}{l}\text { Giovannoni et al., } \\
\text { Lancet Neurol 2011; } \\
\text { Comi et al., J Neurol } \\
2013 \\
\text { (CLARITY study) }\end{array}$ & $\begin{array}{l}\text { RRMS } \\
(n=1326)\end{array}$ & $\begin{array}{l}\text { Cladribine } 3.5 \mathrm{mg} / \mathrm{kg} \text { and } \\
\text { Cladribine } 5.25 \mathrm{mg} / \mathrm{kg} \text { vs. } \\
\text { Placebo, relative } \\
\text { reduction } 24.0 \% \\
(p<0.001) \text { and } 41.2 \% \\
(p<0.001) \text { after } 96 \text { weeks }\end{array}$ & 96 weeks \\
\hline & & $\begin{array}{l}\text { Cohen et al., Lancet } \\
2012 \\
\text { (CARE-MS I) }\end{array}$ & $\begin{array}{l}\text { RRMS } \\
(n=581)\end{array}$ & $\begin{array}{l}\text { Alemtuzumab } 12 \mathrm{mg} \text { vs. } \\
\text { Interferon beta- } 1 \mathrm{a} 44 \mathrm{\mu g}, \\
\text { median percent volume } \\
\text { change }-9.3 \% \text { vs. }-6.5 \% \\
\text { after } 2 \text { years }(p=0.31)\end{array}$ & 24 months \\
\hline & & $\begin{array}{l}\text { Coles et al., Lancet } \\
2012 \\
\text { (CARE-MS II) }\end{array}$ & $\begin{array}{l}\text { RRMS } \\
(n=840)\end{array}$ & $\begin{array}{l}\text { Alemtuzumab } 12 \mathrm{mg} \text { vs. } \\
\text { Interferon beta-1a } 44 \mu \mathrm{g}, \\
\text { median percent volume } \\
\text { change }-1.27 \% \text { vs. }-1.23 \% \\
\text { after } 2 \text { years }(p=0.14)\end{array}$ & 24 months \\
\hline & & $\begin{array}{l}\text { Gold et al., New Eng } \\
\text { J Med 2012; Arnold } \\
\text { et al., J Neurol } 2014 \\
\text { (DEFINE study) }\end{array}$ & $\begin{array}{l}\text { RRMS } \\
(n=1234)\end{array}$ & $\begin{array}{l}\text { Dimethyl Fumarate } \\
240 m g \text { BID and TID vs. } \\
\text { Placebo, in a sub-cohort } \\
\text { of } 540 \text { patients, median } \\
\text { percent volume change - } \\
3.5 \% \text { ( } p<0.001) \text { and }-1.7 \% \\
(p<0.01) \text { vs. } 1.6 \% \text { after } 6 \\
\text { months, }-5.8 \%(p<0.0001) \\
\text { and }-3.7 \%(p<0.0001) \text { vs. } \\
6.5 \% \text { after } 1 \text { year, and - } \\
6.2 \% \text { ( } p<0.0001) \text { and - } \\
1.9 \% \text { ( }<<0.0001) \text { vs. } 20.1 \% \\
\text { after } 2 \text { years }\end{array}$ & 24 months \\
\hline & & $\begin{array}{l}\text { Lublin et al., Ann } \\
\text { Neurol } 2013 \\
\text { (CombiRx study) }\end{array}$ & $\begin{array}{l}\text { RRMS } \\
(n=1008)\end{array}$ & $\begin{array}{l}\text { IFN beta-1a } 30 \mathrm{mcg} \\
\text { SC/week + GA } 20 \mathrm{mg} \\
\text { SC/day vs IFN beta-1a } \\
30 \mathrm{mcg} \text { SC/week vs GA } \\
20 \mathrm{mg} \mathrm{SC/day:} \mathrm{volume} \\
\text { change }-1.38 \mathrm{~mL} \text { vs. - } \\
0.25 \mathrm{~mL} \text { vs. } 0.01 \mathrm{~mL}\end{array}$ & 36 months \\
\hline
\end{tabular}




\begin{tabular}{|c|c|c|c|c|c|}
\hline & & & & $\begin{array}{l}(p=0.008 ; p=0.48) \text { after } 36 \\
\text { months }\end{array}$ & \\
\hline & & \begin{tabular}{|l|} 
Calabresi et al., \\
Lancet Neurol 2014 \\
(FREEDOMS II study)
\end{tabular} & $\begin{array}{l}\text { RRMS } \\
(n=1083)\end{array}$ & $\begin{array}{l}\text { Fingolimod } 1.25 \mathrm{mg} \text { and } \\
0.5 \mathrm{mg} \text { vs. Placebo, } \\
\text { median percent volume } \\
\text { change }-7.69 \%(\mathrm{p}<0.001) \\
\text { and } 13.74 \%(\mathrm{p}<0.001), \text { vs. } \\
25.06 \% \text { after } 24 \text { months }\end{array}$ & 24 months \\
\hline & & $\begin{array}{l}\text { Calabresi et al., } \\
\text { Lancet Neurol 2014; } \\
\text { Arnold et al., BMC } \\
\text { Neurol } 2014 \\
\text { (ADVANCE study) }\end{array}$ & $\begin{array}{l}\text { RRMS } \\
(n=1512)\end{array}$ & $\begin{array}{l}\text { Peginterferon beta-1a } \\
\text { every } 4 \text { and } 2 \text { weeks vs. } \\
\text { Placebo, volume change } \\
0.14 \mathrm{~cm}^{3}(\mathrm{p}=0.0006) \text { and }- \\
0.22 \mathrm{~cm}^{3}(\mathrm{p}<0.0001) \text { vs. } \\
0.34 \mathrm{~cm}^{3} \text { after } 24 \text { weeks, } \\
\text { and } 0.06 \mathrm{~cm}^{3}(p<0.0001) \\
\text { and }-0.26 \mathrm{~cm}^{3}(p<0.0001) \\
\text { vs. } 0.77 \mathrm{~cm}^{3} \text { after } 48 \\
\text { weeks }\end{array}$ & 24 months \\
\hline & & $\begin{array}{l}\text { Kappos et al., New } \\
\text { Eng J Med } 2015 \\
\text { (DECIDE study) }\end{array}$ & $\begin{array}{l}\text { RRMS } \\
(n=1841)\end{array}$ & $\begin{array}{l}\text { Daclizumab vs. Interferon, } \\
\text { median percent volume } \\
\text { change }-1.4 \% \text { vs. } 3.4 \% \\
\text { ( } p=0.02) \text { after } 24 \text { weeks; } \\
0.2 \% \text { vs. } 8.6 \% \text { ( } p<0.001) \\
\text { after } 96 \text { weeks; volume of } \\
\text { new or newly enlarged T2 } \\
\text { lesions } 217.0 \mathrm{~mm}^{3} \text { vs. } \\
463.1 \mathrm{~mm}^{3}(p<0.001) \text { after } \\
24 \text { weeks, and } 225.7 \mathrm{~mm}^{3} \\
\text { vs. } 556.8 \mathrm{~mm}^{3}(p<0.001) \\
\text { after } 96 \text { weeks }\end{array}$ & 144 weeks \\
\hline & & \begin{tabular}{|l|} 
Miller et al., \\
Neurology 2015 \\
(CONFIRM study)
\end{tabular} & $\begin{array}{l}\text { RRMS } \\
(n=681)\end{array}$ & $\begin{array}{l}\text { Dimethyl Fumarate } \\
240 \text { mg BID and TID vs. } \\
\text { Glatiramer Acetate vs. } \\
\text { Placebo, median percent } \\
\text { volume change }-4.2 \% \\
\text { ( } p<0.0001),-0.3 \% \\
(p<0.0001) \text {, and }-3.4 \% \\
(p<0.0001) \text { vs. } 4.8 \% \text { after } \\
1 \text { year, and }-7.4 \% \\
(p<0.0001),-1.5 \% \\
(p<0.0001), \text { and }-6.3 \% \\
(p<0.0001) \text { vs. } 14.6 \% \text { after } \\
2 \text { years }\end{array}$ & 24 months \\
\hline \multirow[t]{2}{*}{$\begin{array}{l}\text { Gd-enhancing } \\
\text { lesions }\end{array}$} & $\begin{array}{l}\text { Number of } \\
\text { Gd- } \\
\text { enhancing } \\
\text { lesions }\end{array}$ & $\begin{array}{l}\text { The Interferon beta } \\
\text { Multiple Sclerosis } \\
\text { Study group; Paty et } \\
\text { al., Neurology } 1993 \\
\text { (Interferon beta } \\
\text { Multiple Sclerosis } \\
\text { Study) }\end{array}$ & $\begin{array}{l}\text { RRMS } \\
(n=327)\end{array}$ & $\begin{array}{l}\text { Interferon beta- } 1 \mathrm{~b} \text { vs. } \\
\text { Placebo, median } \\
\text { percentage of scans with } \\
\text { lesions } 5.9 \% \text { vs. } 29.4 \% \\
\text { after } 3 \text { years ( } \mathrm{p}=0.0062) ; \\
\text { median number of lesions } \\
\text { per year } 0.5 \text { vs. } 3.0 \\
\text { ( } \mathrm{p}=0.0089)\end{array}$ & 24 months \\
\hline & & $\begin{array}{l}\text { Jacobs et al., Ann } \\
\text { Neurol } 1996 \\
\text { (MSCRG study) }\end{array}$ & $\begin{array}{l}\text { RRMS } \\
(n=300)\end{array}$ & $\begin{array}{l}\text { Interferon beta-1a } 30 \mu \mathrm{g} \\
\text { vs. Placebo, number of } \\
\text { lesions } 1.04 \text { vs. } 1.59 \text { after } \\
1 \text { year ( } p=0.02 \text { ), and } 0.80 \\
\text { vs. } 1.65 \text { after } 2 \text { years }\end{array}$ & 104 weeks \\
\hline
\end{tabular}




\begin{tabular}{|c|c|c|c|c|c|}
\hline & & & & $\begin{array}{l}(p=0.05) ; \text { scans with } \\
\text { lesions } 29.9 \% \text { vs. } 42.3 \% \\
\text { after } 1 \text { year }(p=0.05)\end{array}$ & \\
\hline & & $\begin{array}{l}\text { Comi et al., Ann } \\
\text { Neurol } 2001 \\
\text { (European/Canadian } \\
\text { Glatiramer Acetate } \\
\text { Study) }\end{array}$ & $\begin{array}{l}\text { RRMS } \\
(n=249)\end{array}$ & 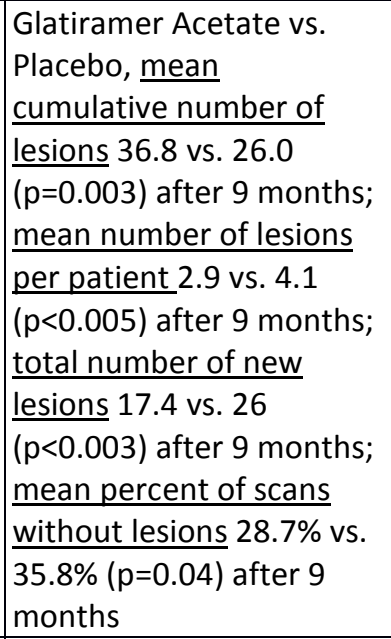 & 9 months \\
\hline & & $\begin{array}{l}\text { Polman et al., New } \\
\text { Eng J Neurol 2006; } \\
\text { Miller et al., } \\
\text { Neurology } 2007 \\
\text { (AFFIRM study) }\end{array}$ & $\begin{array}{l}\text { RRMS } \\
(n=627)\end{array}$ & $\begin{array}{l}\text { Natalizumab vs. Placebo, } \\
\text { number of lesions } 0.1 \text { vs. } \\
1.3 \text { after } 1 \text { year }(p<0.001), \\
0.1 \text { vs. } 1.2 \text { after } 2 \text { years } \\
(p<0.001) \text {, and } 0.2 \text { vs. } 2.4 \\
\text { overall }(p<0.001)\end{array}$ & 24 months \\
\hline & & $\begin{array}{l}\text { Rudick et al., New } \\
\text { Eng J Med } 2006 \\
\text { (SENTINEL study) }\end{array}$ & $\begin{array}{l}\text { RRMS } \\
(n=1171)\end{array}$ & $\begin{array}{l}\text { Natalizumab + Interferon } \\
\text { beta-1a vs. Interferon } \\
\text { beta-1a, number of } \\
\text { lesions } 0.1 \text { vs. } 0.9 \text { after } 2 \\
\text { years }(p<0.001)\end{array}$ & 24 months \\
\hline & & $\begin{array}{l}\text { Mikol et al., Lancet } \\
\text { Neurol } 2008 \\
\text { (REGARD study) }\end{array}$ & $\begin{array}{l}\text { RRMS } \\
(n=764)\end{array}$ & $\begin{array}{l}\text { Interferon beta- } 1^{\mathrm{a}} 44 \mu \mathrm{g} \\
\text { vs. Glatiramer acetate } 20 \\
\text { mg, lesions per patient } \\
\text { per scan } 0.24 \text { vs. } 0.41 \\
\text { after } 96 \text { weeks } \\
\text { ( } p=0.0002) ; \text { scans per } \\
\text { patient with lesions } 9.8 \% \\
\text { vs. } 15.3 \% \text { after } 96 \text { weeks } \\
\text { ( } p=0.005)\end{array}$ & 96 weeks \\
\hline & & $\begin{array}{l}\text { O'Connor et al., } \\
\text { Lancet Neurol } 2009 \\
\text { (BEYOND study) }\end{array}$ & $\begin{array}{l}\text { RRMS } \\
(n=2244)\end{array}$ & $\begin{array}{l}\text { Interferon beta-1a } 500 \mu \mathrm{g} \\
\text { vs. } 250 \mu \mathrm{g} \text { vs. Glatiramer } \\
\text { acetate, number of } \\
\text { lesions } 1.0 \text { vs. } 0.9 \text { vs. } 1.2 \\
\text { after } 2 \text { years ( } p=0.80 ; \\
p=0.07 ; p=0.12 \text { ) }\end{array}$ & 24 months \\
\hline & & $\begin{array}{l}\text { Cohen et al., New } \\
\text { Eng J Med } 2010 \\
\text { (TRANSFORMS } \\
\text { study) }\end{array}$ & $\begin{array}{l}\text { RRMS } \\
(n=1292)\end{array}$ & $\begin{array}{l}\text { Fingolimod } 1.25 \mathrm{mg} \text { and } \\
0.5 \mathrm{mg} \text { vs. Interferon beta- } \\
1 \mathrm{a}(30 \mu \mathrm{g} / \text { week), number } \\
\text { of lesions } 0.14(p<0.001) \\
\text { and } 0.23 \text { ( } p<0.001) \text {, vs. } \\
0.51 \text { after } 12 \text { months }\end{array}$ & 12 months \\
\hline & & $\begin{array}{l}\text { Kappos et al., New } \\
\text { Eng J Med 2010; } \\
\text { Radue et al., Arch } \\
\text { Neurol } 2012 \\
\text { (FREEDOMS study) }\end{array}$ & $\begin{array}{l}\text { RRMS } \\
(n=1272)\end{array}$ & $\begin{array}{l}\text { Fingolimod } 1.25 \mathrm{mg} \text { and } \\
0.5 \mathrm{mg} \text { vs. Placebo, } \\
\text { number of lesions } 0.3 \\
(p<0.001) \text { and } 0.2 \\
(p<0.011), \text { vs. } 1.3 \text { after } 6 \\
\text { months, } 0.3(p<0.001)\end{array}$ & 24 months \\
\hline
\end{tabular}




\begin{tabular}{|c|c|c|c|c|c|}
\hline & & & & $\begin{array}{l}\text { and } 0.2(p<0.011), \text { vs. } 1.1 \\
\text { after } 12 \text { months, } 0.2 \\
(p<0.001) \text { and } 0.2 \\
(p<0.011) \text {, vs. } 1.1 \text { after } 24 \\
\text { months }\end{array}$ & \\
\hline & & $\begin{array}{l}\text { Comi et al., Ann } \\
\text { Neurol } 2011 \\
\text { (FORTE study) }\end{array}$ & $\begin{array}{l}\text { RRMS } \\
(n=980)\end{array}$ & $\begin{array}{l}\text { Glatiramer Acetate } 20 \mathrm{mg} \\
\text { vs. } 40 \mathrm{mg} \text {, number of } \\
\text { lesions } 0.68 \text { vs. } 0.54 \text { (ns) } \\
\text { after } 12 \text { months }\end{array}$ & 12 months \\
\hline & & $\begin{array}{l}\text { Giovannoni et al., } \\
\text { Lancet Neurol 2011; } \\
\text { Comi et al., J Neurol } \\
2013 \\
\text { (CLARITY study) }\end{array}$ & $\begin{array}{l}\text { RRMS } \\
(n=1326)\end{array}$ & $\begin{array}{l}\text { Cladribine } 3.5 \mathrm{mg} / \mathrm{kg} \text { and } \\
\text { Cladribine } 5.25 \mathrm{mg} / \mathrm{kg} \text { vs. } \\
\text { Placebo, relative } \\
\text { reduction } 85.7 \% \\
(p<0.001) \text { and } 87.9 \% \\
(p<0.001) \text { after } 96 \text { weeks } \\
\end{array}$ & 96 weeks \\
\hline & & $\begin{array}{l}\text { O'Connor et al., New } \\
\text { Eng J Med 2011; } \\
\text { Wolinsky et al., Mult } \\
\text { Scler } 2013 \\
\text { (TEMSO study) }\end{array}$ & RMS (1088) & $\begin{array}{l}\text { Teriflunomide } 14 \mathrm{mg} \text { and } \\
7 \mathrm{mg} \text { vs. Placebo, lesions } \\
\text { per scan (relative risk } \\
\text { reduction) } 0.26(80.4 \%) \\
(\mathrm{p}<0.0001) \text { and } 0.57 \\
(57.2 \%)(\mathrm{p}<0.0001), \mathrm{vs} . \\
1.33 \text { after } 108 \text { weeks }\end{array}$ & 108 weeks \\
\hline & & $\begin{array}{l}\text { Cohen et al., Lancet } \\
2012 \\
\text { (CARE-MS I) }\end{array}$ & $\begin{array}{l}\text { RRMS } \\
(n=581)\end{array}$ & \begin{tabular}{|l} 
Alemtuzumab $12 \mathrm{mg}$ vs. \\
Interferon beta-1a $44 \mu \mathrm{g}$, \\
patients with lesions $7 \%$ \\
vs. $19 \%(\mathrm{p}<0.0001)$
\end{tabular} & 24 months \\
\hline & & $\begin{array}{l}\text { Coles et al., Lancet } \\
2012 \\
\text { (CARE-MS II) }\end{array}$ & $\begin{array}{l}\text { RRMS } \\
(n=840)\end{array}$ & \begin{tabular}{|l|} 
Alemtuzumab $12 \mathrm{mg}$ vs. \\
Interferon beta-1a $44 \mu \mathrm{g}$, \\
patients with lesions $9 \%$ \\
vs. $23 \%(\mathrm{p}<0.0001)$ \\
\end{tabular} & 24 months \\
\hline & & \begin{tabular}{|l|} 
Comi et al., NEJM \\
2012; Filippi et al., J \\
Neurol Neurosurg \\
Psychiatry. 2014 \\
(ALLEGRO study) \\
\end{tabular} & $\begin{array}{l}\text { RRMS } \\
(n=1106)\end{array}$ & $\begin{array}{l}\text { Laquinimod vs. Placebo, } \\
\text { cumulative number of } \\
\text { lesions } 1.33 \text { vs. } 2.12 \\
\begin{array}{l}(p<0.001) \text { at } 12 \text { and } 24 \\
\text { months }\end{array}\end{array}$ & 24 months \\
\hline & & $\begin{array}{l}\text { Fox et al., New Eng J } \\
\text { Med. 2012 } \\
\text { (CONFIRM) }\end{array}$ & \begin{tabular}{|l|} 
RRMS \\
( $\mathrm{n}=682, \mathrm{MRI}$ \\
cohort)
\end{tabular} & $\begin{array}{l}\text { Dimethyl Fumarate } \\
\text { 240mg BID or TID or } \\
\text { Glatiramer acetate vs. } \\
\text { Placebo, number of } \\
\text { lesions } 0.5(p<0.001), 0.4 \\
\begin{array}{l}(p<0.001), 0.7(p<0.001) \\
\text { vs. } 2.0 \text { after } 2 \text { years }\end{array}\end{array}$ & 24 months \\
\hline & & $\begin{array}{l}\text { Gold et al., New Eng } \\
\text { J Med 2012; Arnold } \\
\text { et al., J Neurol } 2014 \\
\text { (DEFINE study) }\end{array}$ & \begin{tabular}{|l|} 
RRMS \\
$(n=1234)$
\end{tabular} & $\begin{array}{l}\text { Dimethyl Fumarate } \\
240 \mathrm{mg} \text { BID and TID vs. } \\
\text { Placebo, number of } \\
\text { lesions } 0.1(p<0.001), 0,5 \\
\text { ( } p<0.001), \text { vs. } 1.8 \text { after } 96 \\
\text { weeks; in a sub-cohort of } \\
540 \text { patients, } 0.1 \\
(p<0.0001) \text { and } 0.3 \\
(p<0.0001) \text { vs. } 1.5 \text { after } 6 \\
\text { months, } 0.1 \text { ( } p<0.0001) \\
\text { and } 0.4(p<0.0001) \text { vs. } 1.4 \\
\text { after } 1 \text { year, and } 0.1 \\
(p<0.0001) \text { and } 0.5 \\
(p<0.0001) \text { vs. } 1.8 \text { after } 2 \\
\end{array}$ & 24 months \\
\hline
\end{tabular}




\begin{tabular}{|c|c|c|c|c|c|}
\hline & & & & years & \\
\hline & & \begin{tabular}{|l|} 
Khan et al., Ann \\
Neurol 2013; \\
Zivadinov et al., J \\
Neurol 2015 \\
(GALA study)
\end{tabular} & \begin{tabular}{|l} 
RRMS \\
$(\mathrm{n}=1404)$
\end{tabular} & $\begin{array}{l}\text { Glatiramer acetate } 40 \mathrm{mg} \\
\text { vs. Placebo, cumulative } \\
\text { number of lesions } 0.905 \\
\text { vs. } 1.639 \text { after } 6 \text { and } 12 \\
\text { months }(p<0.0001)\end{array}$ & 12 months \\
\hline & & $\begin{array}{l}\text { Calabresi et al., } \\
\text { Lancet Neurol 2014; } \\
\text { Arnold et al., BMC } \\
\text { Neurol } 2014 \\
\text { (ADVANCE study) }\end{array}$ & \begin{tabular}{|l} 
RRMS \\
$(n=1512)$
\end{tabular} & \begin{tabular}{|l} 
Peginterferon beta-1a \\
every 4 vs. 2 weeks vs. \\
Placebo, number of \\
lesions 1.2 vs. 0.3 vs. 1.6 \\
( $p<0.0001 ; p<0.0001 ;$ \\
$p=0.099)$ after 24 weeks, \\
and 0.9 vs. 0.2 vs. 1.4 \\
$(p<0.0001 ; p<0.0001 ;$ \\
$p=0.074)$ after 48 weeks
\end{tabular} & 24 months \\
\hline & & \begin{tabular}{|l|} 
Calabresi et al., \\
Lancet Neurol 2014 \\
(FREEDOMS II study)
\end{tabular} & $\begin{array}{l}\text { RRMS } \\
(n=1083)\end{array}$ & $\begin{array}{l}\text { Fingolimod } 1.25 \mathrm{mg} \text { and } \\
0.5 \mathrm{mg} \text { vs. Placebo, } \\
\text { number of lesions } 0.2 \\
(p<0.001) \text { and } 0.4 \\
(p<0.001), \text { vs. } 1.2 \text { after } 24 \\
\text { months } \\
\end{array}$ & 24 months \\
\hline & & $\begin{array}{l}\text { Massacesi et al., } \\
\text { PloS One 2014 } \\
\text { (EudraCT 2006- } \\
\text { 004937-13) }\end{array}$ & $\begin{array}{l}\text { RRMS } \\
(n=150)\end{array}$ & $\begin{array}{l}\text { Azatioprine }(3 \mathrm{mg} / \mathrm{kg} / \text { day) } \\
\text { vs. Interferon, number of } \\
\text { lesions } 0.2 \text { vs. } 0.4 \text { after } 2 \\
\text { years }(\mathrm{p}=0.52) ; \text { and } \\
\text { number of patients with } \\
\text { lesions }(0,1-2, \geq 3) 41 / 8 / 0 \\
\text { vs. } 43 / 1 / 3 \text { after } 2 \text { years } \\
(p=0.39)\end{array}$ & 24 months \\
\hline & & \begin{tabular}{|l|} 
Vollmer et al., J \\
Neurol 2014 \\
(BRAVO)
\end{tabular} & \begin{tabular}{|l|} 
RRMS \\
$(n=1331)$
\end{tabular} & $\begin{array}{l}\text { Laquinimod or Interferon } \\
\text { beta-1a } 30 \mu \mathrm{g} \text { vs. Placebo, } \\
\text { cumulative number of } \\
\text { lesions } 1.84(\mathrm{p}=0.069) \text { or } \\
0.90(\mathrm{p}<0.001) \text { vs. } 2.34 \\
\text { after } 12 \text { an } 24 \text { months }\end{array}$ & 24 months \\
\hline & & $\begin{array}{l}\text { Cohen et al., JAMA } \\
\text { Neurol } 2015 \\
\text { (equivalence study) } \\
\text { (GATE study) }\end{array}$ & $\begin{array}{l}\text { RRMS } \\
(n=794)\end{array}$ & $\begin{array}{l}\text { Glatiramer acetate } 20 \mathrm{mg} \\
\text { generic or brand version } \\
\text { vs. Placebo, number of } \\
\text { lesions } 0.42(p<0.001) \text {, or } \\
0.38 \text { ( }<0.001), \text { vs. } 0.82 \\
\text { during months } 7 \text { through } \\
9 \text {; ratio of generic drug to } \\
\text { brand drug of } 1.095\end{array}$ & 9 months \\
\hline & & $\begin{array}{l}\text { Kappos et al., New } \\
\text { Eng J Med } 2015 \\
\text { (DECIDE study) }\end{array}$ & $\begin{array}{l}\text { RRMS } \\
(n=1841)\end{array}$ & $\begin{array}{l}\text { Daclizumab vs. Interferon, } \\
\text { number of lesions } 0.5 \text { vs. } \\
0.8(p<0.001) \text { after } 24 \\
\text { weeks }\end{array}$ & 144 weeks \\
\hline & & \begin{tabular}{|l|} 
Miller et al., \\
Neurology 2015 \\
(CONFIRM study)
\end{tabular} & $\begin{array}{l}\text { RRMS } \\
(n=681)\end{array}$ & 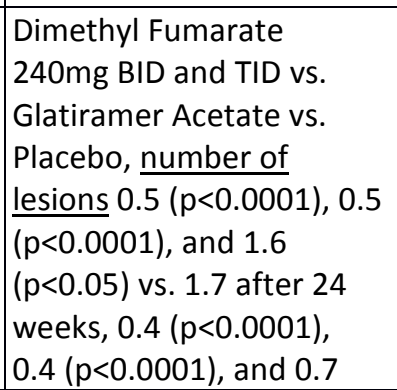 & 24 months \\
\hline
\end{tabular}




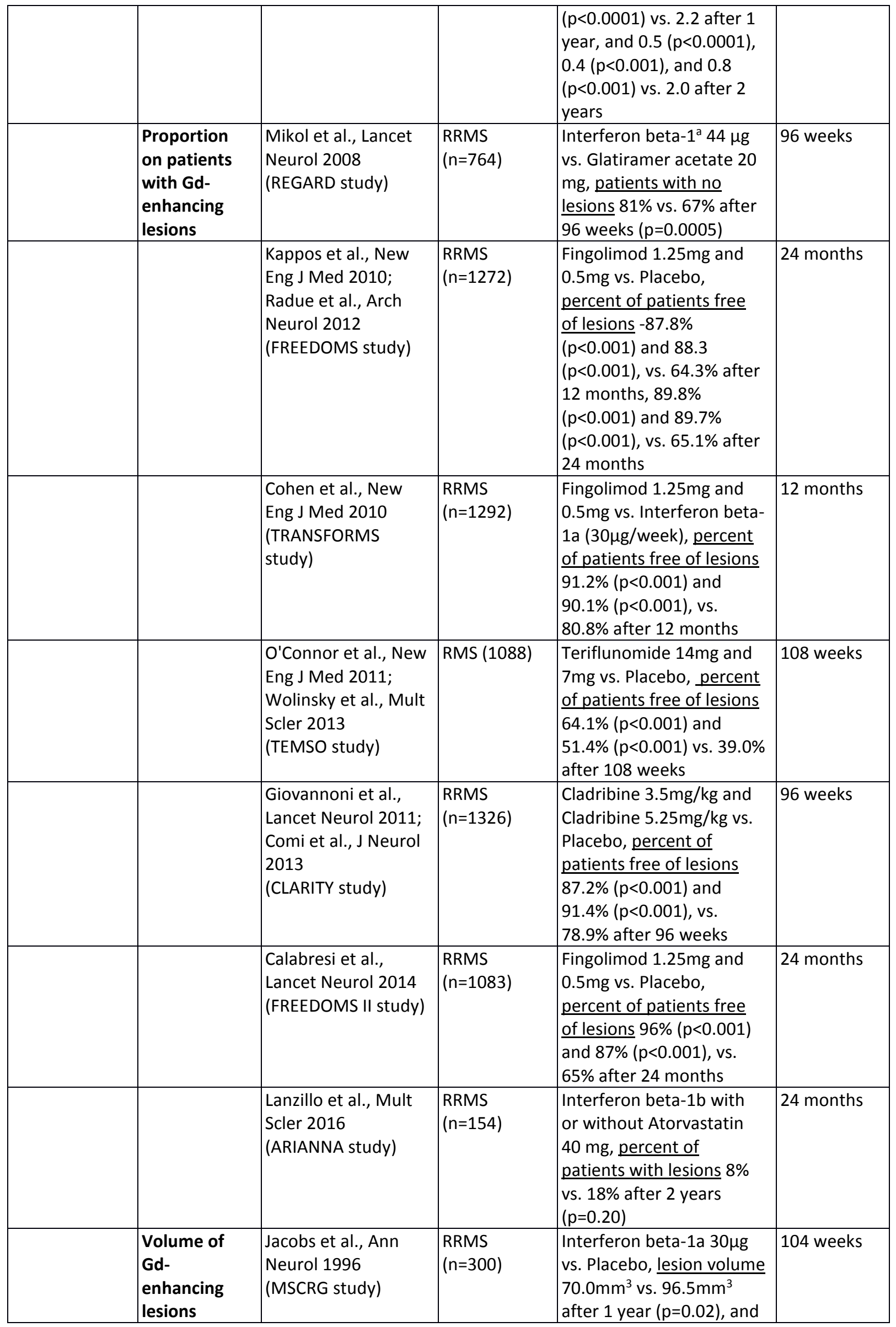




\begin{tabular}{|c|c|c|c|c|c|}
\hline & & & & $\begin{array}{l}38.3 \mathrm{~mm}^{3} \text { vs. } 48.5 \mathrm{~mm}^{3} \\
\text { after } 2 \text { years }(p=0.03)\end{array}$ & \\
\hline & & $\begin{array}{l}\text { Comi et al., Ann } \\
\text { Neurol } 2001 \\
\text { (European/Canadian } \\
\text { Glatiramer Acetate } \\
\text { Study) }\end{array}$ & $\begin{array}{l}\text { RRMS } \\
(\mathrm{n}=249)\end{array}$ & $\begin{array}{l}\text { Glatiramer Acetate vs. } \\
\text { Placebo, volume change - } \\
245.3 \mu \mathrm{L} \text { vs. }-105.1 \mu \mathrm{L} \\
(\mathrm{p}=0.01) \text { after } 9 \text { months }\end{array}$ & 9 months \\
\hline & & $\begin{array}{l}\text { Polman et al., New } \\
\text { Eng J Neurol 2006; } \\
\text { Miller et al., } \\
\text { Neurology } 2007 \\
\text { (AFFIRM study) }\end{array}$ & \begin{tabular}{|l} 
RRMS \\
$(n=627)$
\end{tabular} & $\begin{array}{l}\text { Natalizumab vs. Placebo, } \\
\text { lesion volume of } 21 \mathrm{~mm}^{3} \\
\text { vs. } 207 \mathrm{~mm}^{3} \text { after } 1 \text { year } \\
(p<0.001), 32 \mathrm{~mm}^{3} \text { vs. } \\
192 \mathrm{~mm}^{3} \text { after } 2 \text { years } \\
(p<0.001) ; \text { volume change } \\
-343 \mathrm{~mm}^{3} \text { vs. }-126 \mathrm{~mm}^{3} \\
\text { after } 1 \text { year }(p<0.001), \\
\text { and }-332 \mathrm{~mm}^{3} \text { vs. - } \\
141 \mathrm{~mm}^{3} \text { after } 2 \text { years } \\
(p<0.001)\end{array}$ & 24 months \\
\hline & & $\begin{array}{l}\text { Mikol et al., Lancet } \\
\text { Neurol } 2008 \\
\text { (REGARD study) }\end{array}$ & $\begin{array}{l}\text { RRMS } \\
(n=764)\end{array}$ & $\begin{array}{l}\text { Interferon beta-1a } 44 \mu \mathrm{g} \\
\text { vs. Glatiramer acetate } 20 \\
\mathrm{mg}, \text { volume change - } \\
164.3 \mathrm{~mm}^{3} \text { vs. }-162.6 \mathrm{~mm}^{3} \\
\text { after } 96 \text { weeks }(p=0.42)\end{array}$ & 96 weeks \\
\hline & & $\begin{array}{l}\text { O'Connor et al., } \\
\text { Lancet Neurol } 2009 \\
\text { (BEYOND study) }\end{array}$ & $\begin{array}{l}\text { RRMS } \\
(n=2244)\end{array}$ & $\begin{array}{l}\text { Interferon beta-1a } 500 \mu \mathrm{g} \\
\text { vs. } 250 \mu \mathrm{g} \text { vs. Glatiramer } \\
\text { acetate, } \underline{\text { cumulative }} \\
\text { volume } 0.11 \mathrm{~cm}^{3} \text { vs. } \\
0.12 \mathrm{~cm}^{3} \text { vs. } 0.14 \mathrm{~cm}^{3} \text { after } \\
2 \text { years }(p=0.87 ; p=0.028 ; \\
p=0.017)\end{array}$ & 24 months \\
\hline & & $\begin{array}{l}\text { Cohen et al., New } \\
\text { Eng J Med } 2010 \\
\text { (TRANSFORMS } \\
\text { study) }\end{array}$ & $\begin{array}{l}\text { RRMS } \\
(n=1292)\end{array}$ & $\begin{array}{l}\text { Fingolimod } 1.25 \mathrm{mg} \text { and } \\
0.5 \mathrm{mg} \text { vs. Interferon beta- } \\
1 \text { a }(30 \mu \mathrm{g} / \text { week), lesion } \\
\text { volume } 19.54 \mathrm{~mm}^{3} \\
(\mathrm{p}<0.001) \text { and } 22.61 \mathrm{~mm}^{3} \\
(p<0.001), \text { vs. } 50.68 \mathrm{~mm}^{3} \\
\text { after } 12 \text { months }\end{array}$ & 12 months \\
\hline & & $\begin{array}{l}\text { Gold et al., New Eng } \\
\text { J Med 2012; Arnold } \\
\text { et al., J Neurol } 2014 \\
\text { (DEFINE study) }\end{array}$ & $\begin{array}{l}\text { RRMS } \\
(n=1234)\end{array}$ & $\begin{array}{l}\text { Dimethyl Fumarate } \\
240 \mathrm{mg} \text { BID and TID vs. } \\
\text { Placebo, in a sub-cohort } \\
\text { of } 540 \text { patients, median } \\
\text { volume change - } \\
203.2 \mathrm{~mm}^{3}(p<0.01) \text { and - } \\
118.7 \mathrm{~mm}^{3}(p<0.05) \text { vs. - } \\
1.8 \mathrm{~mm}^{3} \text { after } 6 \text { months, - } \\
160.9 \mathrm{~mm}^{3}(p<0.01) \text { and - } \\
110.2 \mathrm{~mm}^{3}(p<0.01) \text { vs. - } \\
12.6 \mathrm{~mm}^{3} \text { after } 1 \text { year, and } \\
-152.7 \mathrm{~mm}^{3}(p<0.0001) \\
\text { and }-57.8 \mathrm{~mm}^{3}(p<0.0001) \\
\text { vs. } 15.1 \mathrm{~mm}^{3} \text { after } 2 \text { years }\end{array}$ & 24 months \\
\hline & & $\begin{array}{l}\text { Miller et al., } \\
\text { Neurology } 2015 \\
\text { (CONFIRM study) }\end{array}$ & $\begin{array}{l}\text { RRMS } \\
(n=681)\end{array}$ & $\begin{array}{l}\text { Dimethyl Fumarate } \\
\text { 240mg BID and TID vs. } \\
\text { Glatiramer Acetate vs. } \\
\text { Placebo, mean lesion } \\
\text { volume } 46.0 \mathrm{~mm}^{3}\end{array}$ & 24 months \\
\hline
\end{tabular}




\begin{tabular}{|c|c|c|c|c|c|}
\hline & & & & $\begin{array}{l}(p<0.0001), 30.9 \mathrm{~mm}^{3} \\
(p<0.0001), \text { and } \\
162.5 \mathrm{~mm}^{3}(p=0.0544) \text { vs. } \\
143.6 \mathrm{~mm}^{3} \text { after } 24 \text { weeks, } \\
27.0 \mathrm{~mm}^{3}(p<0.0001), \\
56.2 \mathrm{~mm}^{3}(p<0.0001), \text { and } \\
77.0 \mathrm{~mm}^{3}(p=0.0544) \text { vs. } \\
189.5 \mathrm{~mm}^{3} \text { after } 1 \text { year, } \\
\text { and } 35.9 \mathrm{~mm}^{3}(p<0.0001), \\
42.6 \mathrm{~mm}^{3}(p<0.0001), \text { and } \\
45.6 \mathrm{~mm}^{3}(p<0.0001) \text { vs. } \\
141.8 \mathrm{~mm}^{3} \text { after } 2 \text { years } \\
\end{array}$ & \\
\hline \multirow[t]{6}{*}{ T1 lesions } & $\begin{array}{l}\text { Number of } \\
\text { new T1 } \\
\text { lesions }\end{array}$ & $\begin{array}{l}\text { Polman et al., New } \\
\text { Eng J Neurol 2006; } \\
\text { Miller et al., } \\
\text { Neurology } 2007 \\
\text { (AFFIRM study) }\end{array}$ & $\begin{array}{l}\text { RRMS } \\
(n=627)\end{array}$ & $\begin{array}{l}\text { Natalizumab vs. Placebo, } \\
\text { number of lesions } 0.6 \text { vs. } \\
2.3 \text { after } 1 \text { year }(p<0.001), \\
0.4 \text { vs. } 2.3 \text { lesions after } 2 \\
\text { years }(p<0.001) \text {, and } 1.1 \\
\text { vs. } 4.6 \text { overall }(p<0.001)\end{array}$ & 24 months \\
\hline & & $\begin{array}{l}\text { Mikol et al., Lancet } \\
\text { Neurol } 2008 \\
\text { (REGARD study) }\end{array}$ & $\begin{array}{l}\text { RRMS } \\
(n=764)\end{array}$ & $\begin{array}{l}\text { Interferon beta- } 1^{\text {a }} 44 \mu \mathrm{g} \\
\text { vs. Glatiramer acetate } 20 \\
\text { mg, lesions per patient } \\
\text { per scan } 0.23 \text { vs. } 0.24 \\
\text { after } 96 \text { weeks ( } p=0.15) ; \\
\text { scans per patient with } \\
\text { lesions } 10.5 \% \text { vs. } 12.4 \% \\
\text { after } 96 \text { weeks ( } p=0.12) ; \\
\text { patients with no lesions } \\
75 \% \text { vs. } 70 \% \text { after } 96 \\
\text { weeks }(p=0.29)\end{array}$ & 96 weeks \\
\hline & & $\begin{array}{l}\text { O'Connor et al., New } \\
\text { Eng J Med 2011; } \\
\text { Wolinsky et al., Mult } \\
\text { Scler } 2013 \\
\text { (TEMSO study) }\end{array}$ & RMS (1088) & $\begin{array}{l}\text { Teriflunomide } 14 \mathrm{mg} \text { and } \\
7 \mathrm{mg} \text { vs. Placebo, mean } \\
\text { difference from Placebo - } \\
0.030(p=0.0161) \text { and - } \\
0.016(p=0.1916) \text { after } \\
108 \text { weeks }\end{array}$ & 108 weeks \\
\hline & & $\begin{array}{l}\text { Comi et al., New Eng } \\
\text { J Med 2012; Filippi } \\
\text { et al., J Neurol } \\
\text { Neurosurg } \\
\text { Psychiatry. } 2014 \\
\text { (ALLEGRO study) }\end{array}$ & $\begin{array}{l}\text { RRMS } \\
(n=1106)\end{array}$ & $\begin{array}{l}\text { Laquinimod vs. Placebo, } \\
\text { cumulative number of } \\
\text { lesions } 1.61 \text { vs. } 2.23 \\
(\mathrm{p}=0.004) \text { after } 24 \text { months }\end{array}$ & 24 months \\
\hline & & $\begin{array}{l}\text { Fox et al., New Eng J } \\
\text { Med. } 2012 \\
\text { (CONFIRM study) }\end{array}$ & $\begin{array}{l}\text { RRMS } \\
\text { (n=682, MRI } \\
\text { cohort) }\end{array}$ & $\begin{array}{l}\text { Dimethyl Fumarate } \\
240 \mathrm{mg} \text { BID or TID or } \\
\text { Glatiramer acetate vs. } \\
\text { Placebo, number of } \\
\text { lesions } 3.0(p<0.001), 2.4 \\
\text { ( } p<0.001), 4.1(p=0.002), \\
\text { vs. } 7.0 \text { after } 2 \text { years }\end{array}$ & 24 months \\
\hline & & $\begin{array}{l}\text { Calabresi et al., } \\
\text { Lancet Neurol 2014; } \\
\text { Arnold et al., BMC } \\
\text { Neurol } 2014 \\
\text { (ADVANCE study) }\end{array}$ & $\begin{array}{l}\text { RRMS } \\
(n=1512)\end{array}$ & $\begin{array}{l}\text { Peginterferon beta-1a } \\
\text { every } 4 \text { vs. every } 2 \text { weeks, } \\
\text { vs. Placebo, number of } \\
\text { lesions } 2.0 \text { vs. } 1.2 \text { vs. } 2.1 \\
\text { ( } p<0.0001 ; p<0.0001 ; \\
p=0.23) \text { after } 24 \text { weeks, } \\
\text { and } 3.1 \text { vs. } 1.8 \text { vs. } 3.8 \\
\text { ( } p<0.0001 ; p<0.0001 ;\end{array}$ & 24 months \\
\hline
\end{tabular}




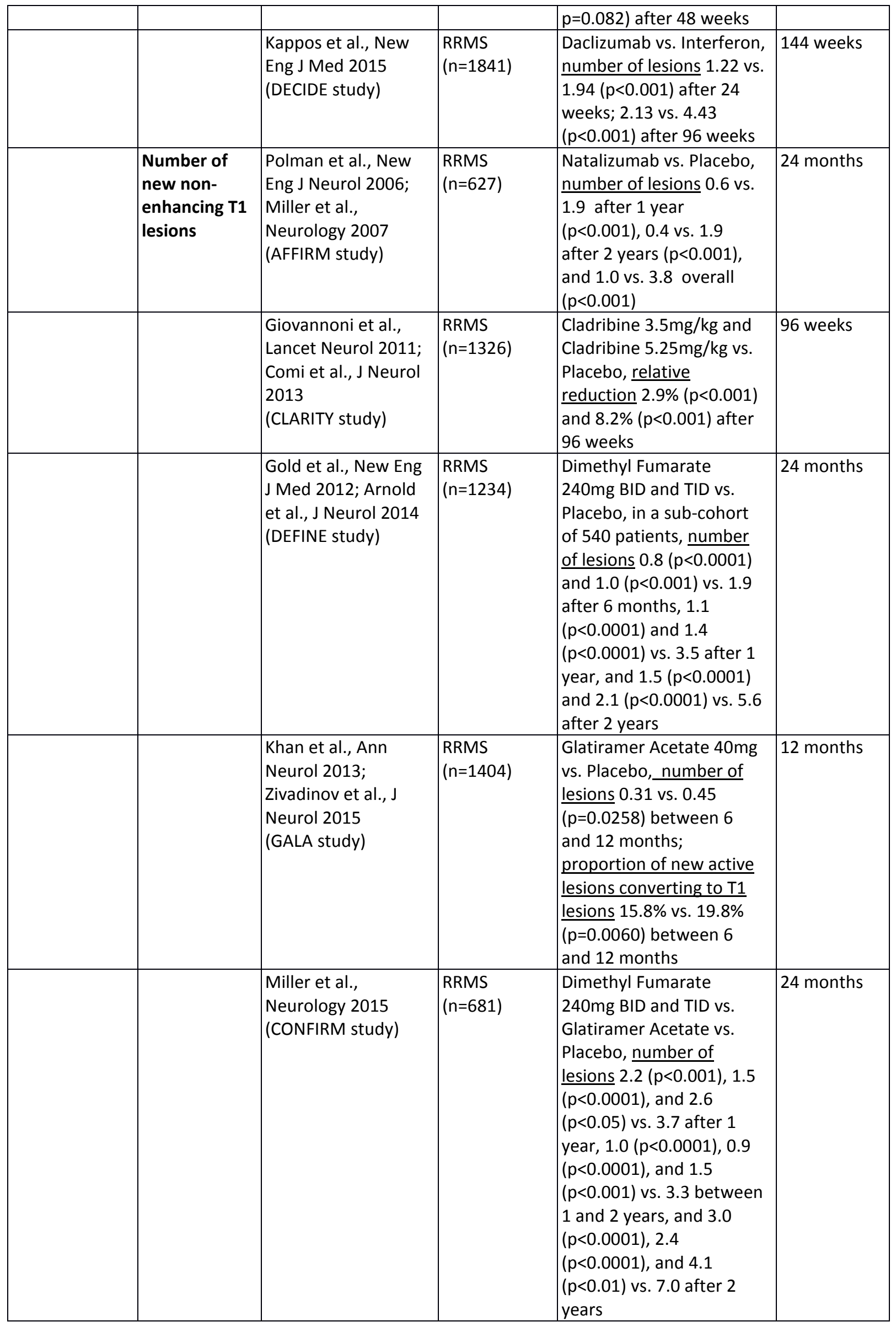




\begin{tabular}{|c|c|c|c|c|}
\hline $\begin{array}{l}\text { Volume of T1 } \\
\text { lesions }\end{array}$ & \begin{tabular}{|l|} 
Comi et al., Ann \\
Neurol 2001 \\
(European/Canadian \\
Glatiramer Acetate \\
Study)
\end{tabular} & $\begin{array}{l}\text { RRMS } \\
(n=249)\end{array}$ & $\begin{array}{l}\text { Glatiramer Acetate vs. } \\
\text { Placebo, volume change } \\
0.8 \mathrm{~mL} \text { vs. } 1.3 \mathrm{~mL}(\mathrm{p}=0.14) \\
\text { after } 9 \text { months }\end{array}$ & 9 months \\
\hline & $\begin{array}{l}\text { Polman et al., New } \\
\text { Eng J Neurol 2006; } \\
\text { Miller et al., } \\
\text { Neurology } 2007 \\
\text { (AFFIRM study) }\end{array}$ & $\begin{array}{l}\text { RRMS } \\
(n=627)\end{array}$ & $\begin{array}{l}\text { Natalizumab vs. Placebo, } \\
\text { volume after } 1(p=0.004) \\
\text { and } 2 \text { years }(p<0.001) ; \\
\text { volume change of - } \\
1508 \mathrm{~mm}^{3} \text { vs. } 548 \mathrm{~mm}^{3} \\
\text { overall ( } p<0.001) ; \text { percent } \\
\text { change }-23.5 \% \text { vs. }-1.5 \% \\
\text { overall }(p<0.001)\end{array}$ & 24 months \\
\hline & $\begin{array}{l}\text { Mikol et al., Lancet } \\
\text { Neurol } 2008 \\
\text { (REGARD study) }\end{array}$ & $\begin{array}{l}\text { RRMS } \\
(n=764)\end{array}$ & $\begin{array}{l}\text { Interferon beta- } 1^{\text {a }} 44 \mu \mathrm{g} \\
\text { vs. Glatiramer acetate } 20 \\
\mathrm{mg}, \text { volume change - } \\
667.0 \mathrm{~mm}^{3} \text { vs. }-377.3 \mathrm{~mm}^{3} \\
\text { after } 96 \text { weeks }(\mathrm{p}=0.29)\end{array}$ & 96 weeks \\
\hline & $\begin{array}{l}\text { O'Connor et al., } \\
\text { Lancet Neurol } 2009 \\
\text { (BEYOND study) }\end{array}$ & \begin{tabular}{|l} 
RRMS \\
$(\mathrm{n}=2244)$
\end{tabular} & $\begin{array}{l}\text { Interferon beta-1a } 500 \mu \mathrm{g} \\
\text { vs. } 250 \mu \mathrm{g} \text { vs. Glatiramer } \\
\text { acetate, percent volume } \\
\text { change } 36.0 \% \text { vs. } 23.1 \% \\
\text { vs. } 40.6 \% \text { after } 2 \text { years } \\
(p=0.18 ; p=0.54 ; p=0.68) \\
\end{array}$ & 24 months \\
\hline & $\begin{array}{l}\text { Cohen et al., New } \\
\text { Eng J Med } 2010 \\
\text { (TRANSFORMS } \\
\text { study) }\end{array}$ & \begin{tabular}{|l} 
RRMS \\
$(n=1292)$
\end{tabular} & 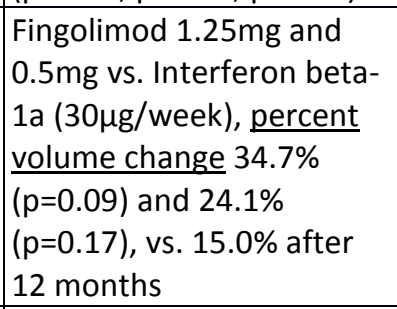 & 12 months \\
\hline & $\begin{array}{l}\text { Kappos et al., New } \\
\text { Eng J Med 2010; } \\
\text { Radue et al., Arch } \\
\text { Neurol } 2012 \\
\text { (FREEDOMS study) }\end{array}$ & $\begin{array}{l}\text { RRMS } \\
(n=1272)\end{array}$ & \begin{tabular}{|l} 
Fingolimod $1.25 \mathrm{mg}$ and \\
0.5mg vs. Placebo, \\
volume change $30 \mathrm{~mm}^{3}$ \\
$(\mathrm{p}<0.001)$ and $33 \mathrm{~mm}^{3}$ \\
$(\mathrm{p}=0.008)$, vs. $173 \mathrm{~mm}^{3}$ \\
after 24 months; percent \\
volume change $12.2 \%$ \\
$(p=0.02)$ and $8.8 \%$ \\
$(p=0.01)$, vs. $50.7 \%$ after \\
24 months
\end{tabular} & 24 months \\
\hline & $\begin{array}{l}\text { O'Connor et al., New } \\
\text { Eng J Med 2011; } \\
\text { Wolinsky et al., Mult } \\
\text { Scler } 2013 \\
\text { (TEMSO study) }\end{array}$ & $\begin{array}{l}\text { RMS } \\
(n=1088)\end{array}$ & $\begin{array}{l}\text { Teriflunomide } 14 \mathrm{mg} \text { and } \\
7 \mathrm{mg} \text { vs. Placebo, volume } \\
\text { change } 0.33 \mathrm{~mL}(\mathrm{p}=0.02) \\
\text { and } 0.50 \mathrm{~mL}(\mathrm{p}=0.19) \text { vs. } \\
0.53 \mathrm{~mL} \text { after } 108 \text { weeks }\end{array}$ & 108 weeks \\
\hline & \begin{tabular}{|l|} 
Sorensen et al., \\
Lancet Neurol 2011 \\
(SIMCOMBIN study)
\end{tabular} & $\begin{array}{l}\text { RRMS } \\
(n=307)\end{array}$ & $\begin{array}{l}\text { Interferon beta- } 1^{\text {a }} 30 \mu \mathrm{g} \\
\text { with vs. without } \\
\text { Simvastatin } 80 \mathrm{mg}, \\
\text { volume change }-0.011 \mathrm{~mL} \\
\text { vs. } 0.019 \mathrm{~mL} \text { after } 12 \\
\text { months ( } \mathrm{p}=0.547)\end{array}$ & 12 months \\
\hline & $\begin{array}{l}\text { Gold et al., New Eng } \\
\text { J Med 2012; Arnold } \\
\text { et al., J Neurol } 2014 \\
\text { (DEFINE study) }\end{array}$ & \begin{tabular}{|l} 
RRMS \\
$(n=1234)$
\end{tabular} & $\begin{array}{l}\text { Dimethyl Fumarate } \\
240 \mathrm{mg} \text { BID and TID vs. } \\
\text { Placebo, in a sub-cohort } \\
\text { of } 540 \text { patients, median } \\
\end{array}$ & 24 months \\
\hline
\end{tabular}




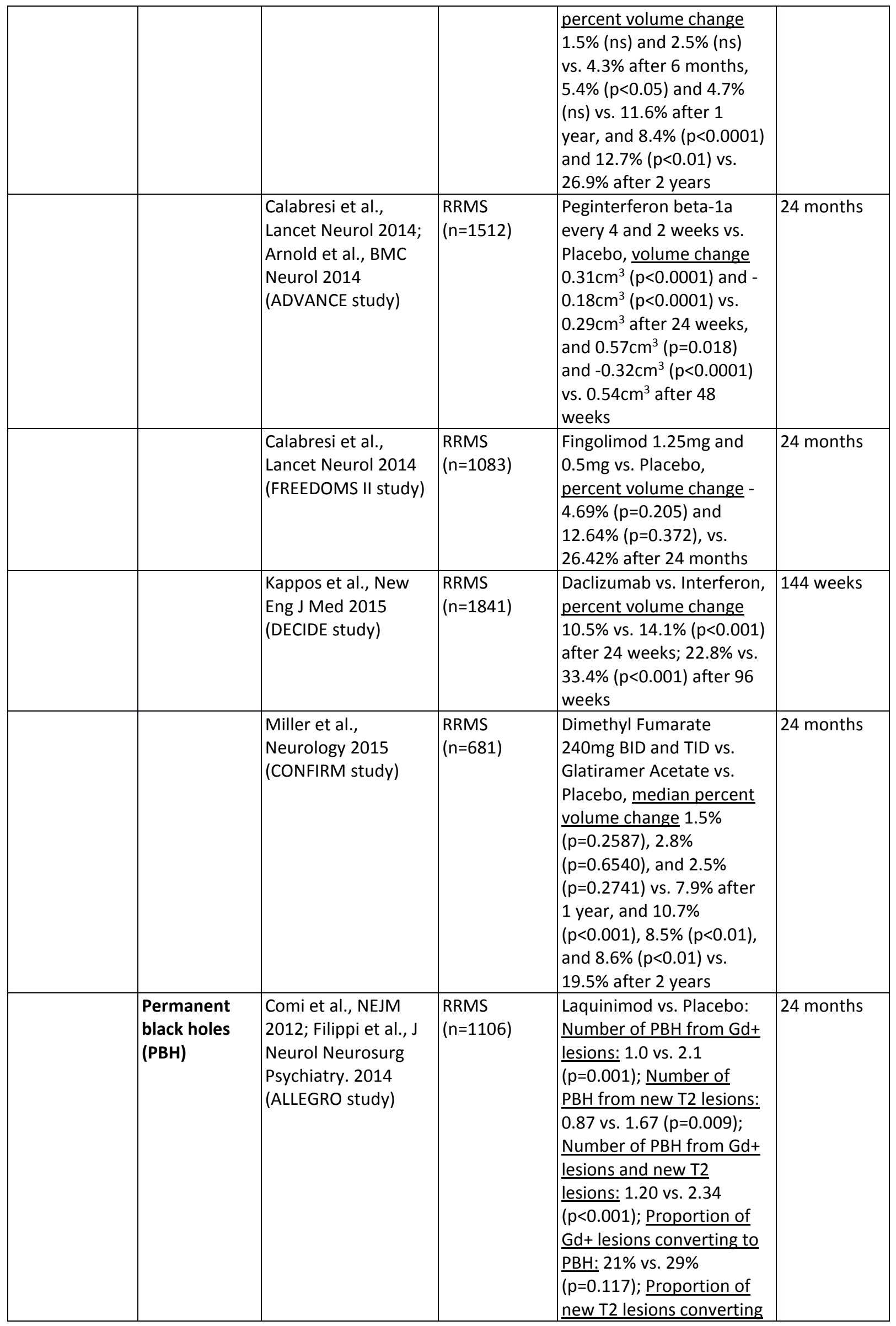




\begin{tabular}{|c|c|c|c|c|c|}
\hline & & & & \begin{tabular}{|l} 
to $\mathrm{PBH}: 23 \%$ vs. $26 \%$ \\
( $\mathrm{p}=0.572) ;$ Proportion of \\
Gd+ lesions and new T2 \\
lesions converting to PBH: \\
$23 \%$ vs. $28 \%(p=0.260) ;$
\end{tabular} & \\
\hline & $\begin{array}{l}\mathrm{T} 1 / \mathrm{T} 2 \text { lesion } \\
\text { volume ratio }\end{array}$ & $\begin{array}{l}\text { Polman et al., New } \\
\text { Eng J Neurol 2006; } \\
\text { Miller et al., } \\
\text { Neurology } 2007 \\
\text { (AFFIRM study) }\end{array}$ & $\begin{array}{l}\text { RRMS } \\
(n=627)\end{array}$ & $\begin{array}{l}\text { Natalizumab vs. Placebo, } \\
\text { ratio } 0.270 \text { vs. } 0.311 \text { after } \\
2 \text { years ( } p=0.002 \\
\text { adjusting for the baseline } \\
\text { ratio); changes in the } \\
\text { ratio }-0.058 \text { vs. vs. }-0.03 \\
\text { ( }=0.002 \text { adjusting for the } \\
\text { baseline ratio) }\end{array}$ & 24 months \\
\hline \multirow[t]{4}{*}{$\begin{array}{l}\text { Combined } \\
\text { measures }\end{array}$} & $\begin{array}{l}\text { Combined } \\
\text { unique active } \\
\text { lesions }\end{array}$ & $\begin{array}{l}\text { Mikol et al., Lancet } \\
\text { Neurol } 2008 \\
\text { (REGARD study) }\end{array}$ & $\begin{array}{l}\text { RRMS } \\
(n=764)\end{array}$ & $\begin{array}{l}\text { Interferon beta- } 1 \text { a } 44 \mu \mathrm{g} \\
\text { vs. Glatiramer acetate } 20 \\
\text { mg, lesions per patient } \\
\text { per scan } 0.91 \text { vs. } 1.22 \\
\text { after } 96 \text { weeks ( } p=0.010) ; \\
\text { scans per patient with } \\
\text { lesions } 26.4 \% \text { vs. } 32.3 \% \\
\text { after } 96 \text { weeks ( } p=0.009) ; \\
\text { patients with no lesions } \\
38 \% \text { vs. } 31 \% \text { after } 96 \\
\text { weeks ( } p=0.125 \text { ) }\end{array}$ & 96 weeks \\
\hline & & $\begin{array}{l}\text { Kappos et al., New } \\
\text { Eng J Med 2010; } \\
\text { Radue et al., Arch } \\
\text { Neurol } 2012 \\
\text { (FREEDOMS study) }\end{array}$ & \begin{tabular}{|l} 
RRMS \\
$(n=1272)$
\end{tabular} & $\begin{array}{l}\text { Fingolimod } 1.25 \mathrm{mg} \text { and } \\
0.5 \mathrm{mg} \text { vs. Placebo, } \\
\text { percent of patients } \\
\text { lesion-free } 58.7=2 \% \\
(p<0.001) \text { and } 57.4 \% \\
(p<0.001) \text { vs. } 27.1 \% \text { after } \\
12 \text { months, } 69.6 \% \\
(p<0.001) \text { and } 73.1 \% \\
(p<0.001) \text { vs. } 33.1 \% \\
\text { between } 12 \text { and } 24 \\
\text { months, and } 52.0 \% \\
(p<0.001) \text { and } 50.7 \% \\
\text { ( } p<0.001) \text { vs. } 21.0 \% \text { after } \\
24 \text { months }\end{array}$ & 24 months \\
\hline & & $\begin{array}{l}\text { Giovannoni et al., } \\
\text { Lancet Neurol 2011; } \\
\text { Comi et al., J Neurol } \\
2013 \\
\text { (CLARITY study) }\end{array}$ & $\begin{array}{l}\text { RRMS } \\
(n=1326)\end{array}$ & $\begin{array}{l}\text { Cladribine } 3.5 \mathrm{mg} / \mathrm{kg} \text { and } \\
\text { Cladribine } 5.25 \mathrm{mg} / \mathrm{kg} \text { vs. } \\
\text { Placebo, proportion of } \\
\text { patients with MRI lesion } \\
\text { activity-free } 60.0 \% \\
\text { ( } p<0.001) \text { and } 61.2 \% \\
(p<0.001), \text { vs. } 25.5 \% \text { after } \\
96 \text { weeks; relative } \\
\text { reduction: } 0.43(p<0.001) \\
\text { and } 0.38 \text { ( } p<0.001) \text { vs. } \\
1.72 \text { after } 96 \text { weeks }\end{array}$ & 96 weeks \\
\hline & & $\begin{array}{l}\text { O'Connor et al., New } \\
\text { Eng J Med 2011; } \\
\text { Wolinsky et al., Mult } \\
\text { Scler } 2013 \\
\text { (TEMSO study) }\end{array}$ & RMS (1088) & $\begin{array}{l}\text { Teriflunomide } 14 \mathrm{mg} \text { and } \\
7 \mathrm{mg} \text { vs. Placebo, lesions } \\
\text { per scan (percent } \\
\text { reduction vs Placebo) } \\
0.75(69.4 \%)(p<0.0001) \\
\text { and } 1.29(47.7 \%) \\
(p<0.0001) \text { vs. } 2.46 \text { after }\end{array}$ & 108 weeks \\
\hline
\end{tabular}




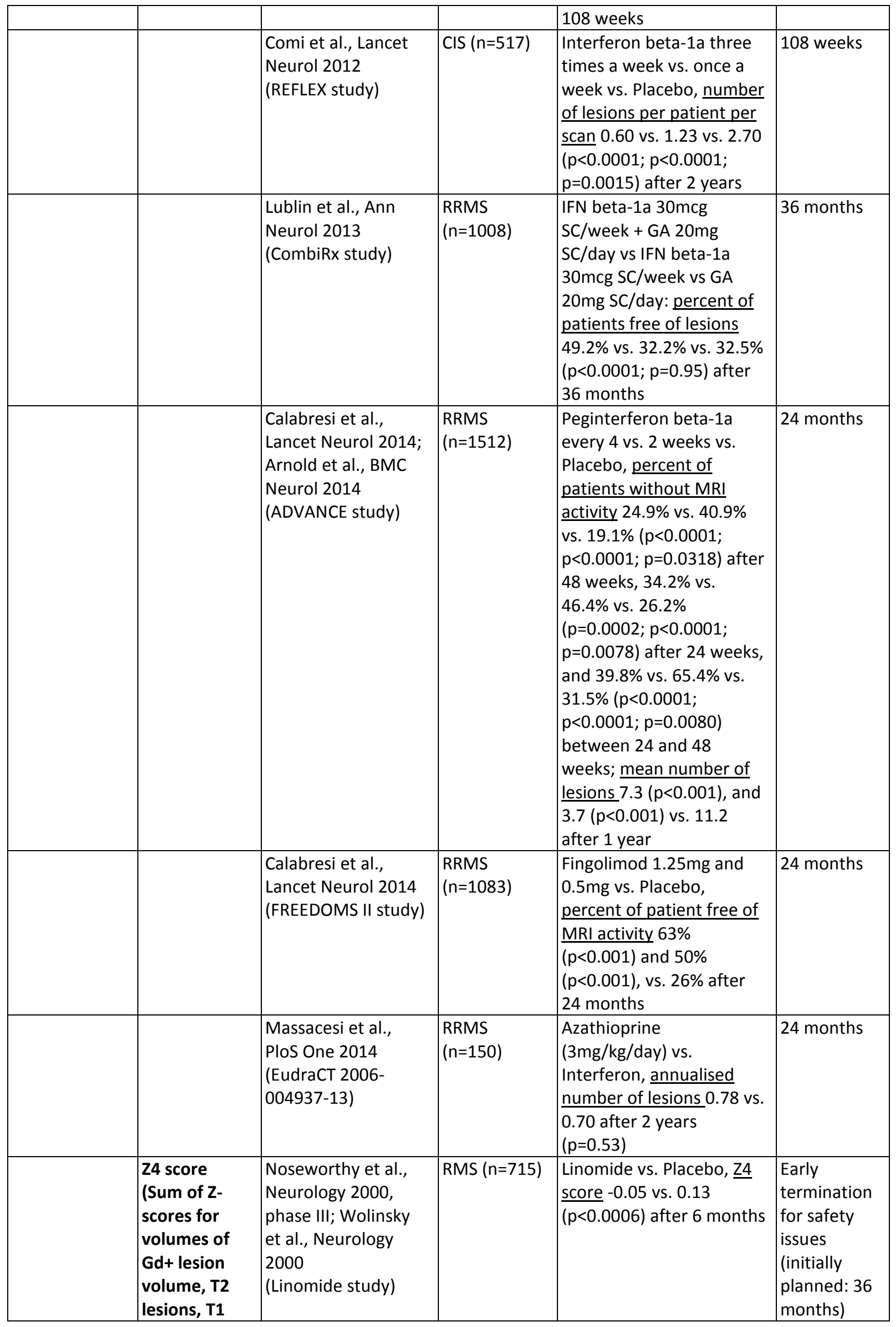




\begin{tabular}{|c|c|c|c|c|c|}
\hline & $\begin{array}{l}\text { lesions and } \\
\text { CSF) }\end{array}$ & & & & \\
\hline & & $\begin{array}{l}\text { O'Connor et al., New } \\
\text { Eng J Med 2011; } \\
\text { Wolinsky et al., Mult } \\
\text { Scler } 2013 \\
\text { (TEMSO study) }\end{array}$ & RMS (1088) & $\begin{array}{l}\text { Teriflunomide } 14 \mathrm{mg} \text { and } \\
7 \mathrm{mg} \text { vs. Placebo, mean } \mathrm{Z4} \\
\text { score difference from } \\
\text { Placebo }-0.512(p<0.0002) \\
\text { and }-0.333(p=0.0008) \\
\text { after } 108 \text { weeks }\end{array}$ & 108 weeks \\
\hline \multirow[t]{6}{*}{ Brain atrophy } & $\begin{array}{l}\text { Brain } \\
\text { parenchymal } \\
\text { fraction }\end{array}$ & $\begin{array}{l}\text { Polman et al., New } \\
\text { Eng J Neurol 2006; } \\
\text { Miller et al., } \\
\text { Neurology } 2007 \\
\text { (AFFIRM study) }\end{array}$ & $\begin{array}{l}\text { RRMS } \\
(n=627)\end{array}$ & $\begin{array}{l}\text { Natalizumab vs. Placebo, } \\
\text { percent volume change - } \\
0.56 \% \text { vs. }-0.40 \% \text { after } 1 \\
\text { year ( } p=0.002),-0.43 \% \text { vs. } \\
-0.24 \% \text { after } 2 \text { years } \\
(p=0.004) \text {, and }-0.80 \text { vs. - } \\
0.82 \text { overall (ns) }\end{array}$ & 24 months \\
\hline & & $\begin{array}{l}\text { Mikol et al., Lancet } \\
\text { Neurol } 2008 \\
\text { (REGARD study) }\end{array}$ & $\begin{array}{l}\text { RRMS } \\
(n=764)\end{array}$ & $\begin{array}{l}\text { Interferon beta- } 1 \mathrm{a} 44 \mu \mathrm{g} \\
\text { vs. Glatiramer acetate } 20 \\
\mathrm{mg} \text {, percent volume } \\
\text { change }-1.240 \% \text { vs. - } \\
1.073 \% \text { after } 96 \text { weeks } \\
(\mathrm{p}=0.018)\end{array}$ & 96 weeks \\
\hline & & \begin{tabular}{|l|} 
O'Connor et al., \\
Lancet Neurol 2009 \\
(BEYOND study)
\end{tabular} & $\begin{array}{l}\text { RRMS } \\
(n=2244)\end{array}$ & $\begin{array}{l}\text { Interferon beta- } 1 \text { a } 500 \mu \mathrm{g} \\
\text { vs. } 250 \mu \mathrm{g} \text { vs. Glatiramer } \\
\text { acetate, percent volume } \\
\text { change }-0.64 \% \text { vs. }-0.65 \% \\
\text { vs. }-0.61 \% \text { after } 2 \text { years } \\
(p=0.74 ; p=0.33 ; p=0.46)\end{array}$ & 24 months \\
\hline & & $\begin{array}{l}\text { Cohen et al., New } \\
\text { Eng J Med } 2010 \\
\text { (TRANSFORMS } \\
\text { study) }\end{array}$ & $\begin{array}{l}\text { RRMS } \\
(n=1292)\end{array}$ & $\begin{array}{l}\text { Fingolimod } 1.25 \mathrm{mg} \text { and } \\
0.5 \mathrm{mg} \text { vs. Interferon beta- } \\
\text { 1a }(30 \mu \mathrm{g} / \text { week }), \text { percent } \\
\text { volume change }-0.30 \% \\
(p<0.001) \text { and }-0.31 \% \\
(p<0.001), \text { vs. }-0.45 \% \\
\text { after } 12 \text { months }\end{array}$ & 12 months \\
\hline & & $\begin{array}{l}\text { Kappos et al., New } \\
\text { Eng J Med 2010; } \\
\text { Radue et al., Arch } \\
\text { Neurol } 2012 \\
\text { (FREEDOMS study) }\end{array}$ & $\begin{array}{l}\text { RRMS } \\
(n=1272)\end{array}$ & $\begin{array}{l}\text { Fingolimod } 1.25 \mathrm{mg} \text { and } \\
0.5 \mathrm{mg} \text { vs. Placebo, } \\
\text { percent volume change } \\
\text { (relative reduction } \\
\text { compared with Placebo) } \\
(\mathrm{p}=0.006) \text { and }-0.22 \% \\
(39.2 \%)(\mathrm{p}=0.003) \text { vs. - } \\
0.34 \% \text { after } 6 \text { months, - } \\
0.44 \%(22.7 \%)(p=0.03) \\
\text { and }-0.50 \%(32.3 \%) \\
(\mathrm{p}=0.001) \text { vs. }-0.65 \% \text { after } \\
12 \text { months, }-0.42 \% \\
(36.8 \%)(p=0.002) \text { and - } \\
0.37 \%(44.7 \%)(p<0.001) \\
\text { vs. }-0.67 \% \text { between } 12 \\
\text { and } 24 \text { months, }-0.89 \% \\
(35.5 \%)(p<0.001) \text { and }- \\
0.84 \%(32.2 \%)(p<0.001) \\
\text { vs. }-1.31 \% \text { after } 24 \\
\text { months }\end{array}$ & 24 months \\
\hline & & $\begin{array}{l}\text { Comi et al., Ann } \\
\text { Neurol } 2011\end{array}$ & $\begin{array}{l}\text { RRMS } \\
(n=980)\end{array}$ & $\begin{array}{l}\text { Glatiramer Acetate } 20 \mathrm{mg} \\
\text { vs. } 40 \mathrm{mg} \text {, percent volume }\end{array}$ & 12 months \\
\hline
\end{tabular}




\begin{tabular}{|c|c|c|c|c|c|}
\hline & & (FORTE study) & & \begin{tabular}{|l|} 
change $-0.58 \%$ vs. $-0.53 \%$ \\
(ns) after 12 months
\end{tabular} & \\
\hline & & \begin{tabular}{|l|} 
Sorensen et al., \\
Lancet Neurol 2011 \\
(SIMCOMBIN study)
\end{tabular} & $\begin{array}{l}\text { RRMS } \\
(n=307)\end{array}$ & $\begin{array}{l}\text { Interferon beta- } 1^{\text {a }} 30 \mu \mathrm{g} \\
\text { with vs. without } \\
\text { Simvastatin } 80 \mathrm{mg} \text {, } \\
\text { volume change - } \\
0.0099 \mathrm{~mL} \text { vs. }-0.00080 \mathrm{~mL} \\
\text { after } 12 \text { months }(p=0.370)\end{array}$ & 12 months \\
\hline & & $\begin{array}{l}\text { Cohen et al., Lancet } \\
2012 \\
\text { (CARE-MS I) }\end{array}$ & $\begin{array}{l}\text { RRMS } \\
(n=563)\end{array}$ & $\begin{array}{l}\text { Alemtuzumab } 12 \mathrm{mg} \text { vs. } \\
\text { Interferon beta- } 1 \mathrm{a} 44 \mu \mathrm{g}, \\
\text { median percent volume } \\
\text { change }-0.867 \% \text { vs. - } \\
1.488 \% \text { after } 2 \text { years } \\
(\mathrm{p}<0.0001)\end{array}$ & 24 months \\
\hline & & $\begin{array}{l}\text { Coles et al., Lancet } \\
2012 \\
\text { (CARE-MS II) }\end{array}$ & $\begin{array}{l}\text { RRMS } \\
(n=840)\end{array}$ & $\begin{array}{l}\text { Alemtuzumab } 12 \mathrm{mg} \text { vs. } \\
\text { Interferon beta- } 1 \mathrm{a} 44 \mu \mathrm{g}, \\
\text { median percent volume } \\
\text { change }-0.615 \% \text { vs. - } \\
0.810 \% \text { after } 2 \text { years } \\
(\mathrm{p}=0.01)\end{array}$ & 24 months \\
\hline & & $\begin{array}{l}\text { Comi et al., New Eng } \\
\text { J Med. } 2012 \\
\text { (ALLEGRO study) }\end{array}$ & $\begin{array}{l}\text { RRMS } \\
(\mathrm{n}=1106)\end{array}$ & \begin{tabular}{|l} 
Laquinimod vs. Placebo, \\
percent volume change - \\
$0.87 \%$ vs. $-1.30 \%$ \\
$(p<0.001)$ after 24 months
\end{tabular} & 24 months \\
\hline & & $\begin{array}{l}\text { Gold et al., New Eng } \\
\text { J Med 2012; Arnold } \\
\text { et al., J Neurol } 2014 \\
\text { (DEFINE study) }\end{array}$ & $\begin{array}{l}\text { RRMS } \\
(n=1234)\end{array}$ & $\begin{array}{l}\text { Dimethyl Fumarate } \\
240 \mathrm{mg} \text { BID and TID vs. } \\
\text { Placebo, in a sub-cohort } \\
\text { of } 540 \text { patients, median } \\
\text { percent volume change - } \\
0.64 \% \text { ( } p<0.05 \text { ) and - } \\
0.77 \% \text { (ns) vs. }-0.81 \% \\
\text { after } 6 \text { months, }-0.46 \% \\
(p<0.05) \text { and }-0.55 \% \text { (ns) } \\
\text { vs. }-0.66 \% \text { between } 6 \\
\text { months and } 2 \text { years }\end{array}$ & 24 months \\
\hline & & $\begin{array}{l}\text { Khan et al., Ann } \\
\text { Neurol } 2013 \\
\text { Zivadinov et al., J } \\
\text { Neurol } 2015 \\
\text { (GALA study) }\end{array}$ & $\begin{array}{l}\text { RRMS } \\
(n=1404)\end{array}$ & $\begin{array}{l}\text { Glatiramer acetate } 40 \mathrm{mg} \\
\text { vs. Placebo, percent } \\
\text { volume change }-0.706 \% \\
\text { vs. }-0.645 \% \text { after } 12 \\
\text { months }(p=0.2058) \\
\end{array}$ & 12 months \\
\hline & & $\begin{array}{l}\text { Calabresi et al., } \\
\text { Lancet Neurol 2014; } \\
\text { Arnold et al., BMC } \\
\text { Neurol } 2014 \\
\text { (ADVANCE study) }\end{array}$ & $\begin{array}{l}\text { RRMS } \\
(n=1512)\end{array}$ & $\begin{array}{l}\text { Peginterferon beta- } 1 \mathrm{a} \\
\text { every } 4 \text { vs. } 2 \text { weeks vs. } \\
\text { Placebo, mean percent } \\
\text { volume change }-0.671 \% \\
(p=0.3747) \text {, and }-0.721 \% \\
(p=0.0841), \text { vs. }-0.621 \% \\
\text { after } 1 \text { year }\end{array}$ & 24 months \\
\hline & & \begin{tabular}{|l|} 
Calabresi et al., \\
Lancet Neurol 2014 \\
(FREEDOMS II study)
\end{tabular} & $\begin{array}{l}\text { RRMS } \\
(n=1083)\end{array}$ & \begin{tabular}{|l|} 
Fingolimod $1.25 \mathrm{mg}$ and \\
$0.5 \mathrm{mg}$ vs. Placebo, \\
percent volume change - \\
$0.128 \%(\mathrm{p}<0.001)$ and - \\
$0.228 \%(\mathrm{p}=0.012)$, vs. - \\
$0.375 \%$ after 6 months; - \\
$0.354 \%$ ( $p<0.001)$ and - \\
$0.377 \%$ ( $p=0.0004)$, vs. - \\
$0.629 \%$ after 12 months; -
\end{tabular} & 24 months \\
\hline
\end{tabular}




\begin{tabular}{|c|c|c|c|c|}
\hline & & & \begin{tabular}{|l|}
$.285 \%(p<0.001)$ and - \\
$0.486 \%(p=0.013)$, vs. - \\
$0.678 \%$ after 24 months
\end{tabular} & \\
\hline & $\begin{array}{l}\text { Vollmer et al., J } \\
\text { Neurol } 2014 \\
\text { (BRAVO) }\end{array}$ & $\begin{array}{l}\text { RRMS } \\
(n=1331)\end{array}$ & \begin{tabular}{|l} 
Laquinimod or Interferon \\
beta-1a $30 \mu \mathrm{g}$ vs. Placebo, \\
percent volume change - \\
$0.75 \%(p<0.001)$ or - \\
$1.14 \%(p=0.14$ ) vs. $-1.03 \%$ \\
after 24 months
\end{tabular} & 24 months \\
\hline & \begin{tabular}{|l|} 
Miller et al., \\
Neurology 2015 \\
(CONFIRM study)
\end{tabular} & $\begin{array}{l}\text { RRMS } \\
(n=681)\end{array}$ & $\begin{array}{l}\text { Dimethyl Fumarate } \\
240 \mathrm{mg} \text { BID and TID vs. } \\
\text { Glatiramer Acetate vs. } \\
\text { Placebo, median percent } \\
\text { volume change }-0.320 \% \\
(p=0.6645),-0.450 \% \\
(p=0.9299), \text { and }-0.580 \% \\
(p=0.2593) \text { vs. }-0.440 \% \\
\text { after } 1 \text { year, }-0.400 \% \\
(p=0.0359),-0.400 \% \\
(p=0.0755), \text { and }-0.420 \% \\
(p=0.0805) \text { vs. }-0.590 \% \\
\text { between } 1 \text { and } 2 \text { years, } \\
\text { and }-0.660 \%(p=0.0645),- \\
0.750 \%(p=0.2636), \text { and - } \\
0.960 \%(p=0.8802) \text { vs. - } \\
0.945 \% \text { after } 2 \text { years }\end{array}$ & 24 months \\
\hline & $\begin{array}{l}\text { Lanzillo et al., MSJ } \\
2016 \\
\text { (ARIANNA study) }\end{array}$ & $\begin{array}{l}\text { RRMS } \\
(n=154)\end{array}$ & $\begin{array}{l}\text { Interferon beta- } 1 \mathrm{~b} \text { with } \\
\text { or without Atorvastatin } \\
40 \mathrm{mg} \text {, percent volume } \\
\text { change }-0.367 \% \text { vs. - } \\
0.302 \% \text { after } 1 \text { year (ns), - } \\
0.382 \% \text { vs. }-0.545 \% \text { after } \\
2 \text { years (ns); percent } \\
\text { annualized volume } \\
\frac{\text { change }-0.380 \% \text { vs. - }}{0.316 \%(p=0.920)} \\
\end{array}$ & 24 months \\
\hline Grey matter & $\begin{array}{l}\text { O'Connor et al., New } \\
\text { Eng J Med 2011; } \\
\text { Wolinsky et al., MSJ } \\
2013 \\
\text { (TEMSO study) }\end{array}$ & RMS (1088) & $\begin{array}{l}\text { Teriflunomide } 14 \mathrm{mg} \text { and } \\
7 \mathrm{mg} \text { vs. Placebo, volume } \\
\text { change }-0.003 \mathrm{~mL} \\
(\mathrm{p}=0.35) \text { and }-0.003 \mathrm{~mL} \\
(\mathrm{p}=0.19) \text { vs. }-0.004 \mathrm{~mL} \\
\text { after } 108 \text { weeks }\end{array}$ & 108 weeks \\
\hline & $\begin{array}{l}\text { Filippi et al., J Neurol } \\
\text { Neurosurg } \\
\text { Psychiatry. } 2013 \\
\text { (ALLEGRO study) }\end{array}$ & $\begin{array}{l}\text { RRMS } \\
(n=1106)\end{array}$ & $\begin{array}{l}\text { Laquinimod vs. Placebo, } \\
\text { median percent volume } \\
\text { change }-0.3 \% \text { vs. }-0.8 \% \\
(p=0.004) \text { after } 12 \\
\text { months, }-0.7 \% \text { vs. }-0.6 \% \\
(p=0.664) \text { between } 12 \\
\text { and } 24 \text { months, and }-0.9 \% \\
\text { vs. }-1.2 \%(p=0.372) \text { after } \\
24 \text { months }\end{array}$ & 24 months \\
\hline & $\begin{array}{l}\text { Lublin et al., Ann } \\
\text { Neurol } 2013 \\
\text { (CombiRx study) }\end{array}$ & $\begin{array}{l}\text { RRMS } \\
(n=1008)\end{array}$ & $\begin{array}{l}\text { IFN beta-1a 30mcg } \\
\text { SC/week + GA } 20 \mathrm{mg} \\
\text { SC/day vs IFN beta-1a } \\
\text { 30mcg SC/week vs GA }\end{array}$ & 36 months \\
\hline
\end{tabular}




\begin{tabular}{|c|c|c|c|c|c|}
\hline & & & & $\begin{array}{l}20 \mathrm{mg} \text { SC/day: percent } \\
\text { volume change }-2.60 \% \text { vs. } \\
-2.99 \% \text { vs. }-5.16 \% \text { (ns; ns) } \\
\text { after } 36 \text { months }\end{array}$ & \\
\hline & White matter & $\begin{array}{l}\text { O'Connor et al., New } \\
\text { Eng J Med 2011; } \\
\text { Wolinsky et al., Mult } \\
\text { Scler } 2013 \\
\text { (TEMSO study) }\end{array}$ & $\begin{array}{l}\text { RMS } \\
(n=1088)\end{array}$ & $\begin{array}{l}\text { Teriflunomide } 14 \mathrm{mg} \text { and } \\
7 \mathrm{mg} \text { vs. Placebo, } \text { mean } \\
\text { volume difference from } \\
\text { Placebo }-6.146 \mathrm{~mL} \\
(p=0.0002) \text { and }-3.106 \mathrm{~mL} \\
(p=0.0609) \text { after } 108 \\
\text { weeks }\end{array}$ & 108 weeks \\
\hline & & $\begin{array}{l}\text { Filippi et al., J Neurol } \\
\text { Neurosurg } \\
\text { Psychiatry. } 2013 \\
\text { (ALLEGRO study) }\end{array}$ & $\begin{array}{l}\text { RRMS } \\
(n=1106)\end{array}$ & $\begin{array}{l}\text { Laquinimod vs. Placebo, } \\
\text { median percent volume } \\
\text { change }-0.0 \% \text { vs. }-0.4 \% \\
(p=0.004) \text { after } 12 \\
\text { months, }-0.2 \% \text { vs. }-0.2 \% \\
(p=0.857) \text { between } 12 \\
\text { and } 24 \text { months, and }-0.3 \% \\
\text { vs. }-0.5 \%(p=0.327) \text { after } \\
24 \text { months }\end{array}$ & 24 months \\
\hline & & $\begin{array}{l}\text { Lublin et al., Ann } \\
\text { Neurol } 2013 \\
\text { (CombiRx study) }\end{array}$ & $\begin{array}{l}\text { RRMS } \\
(n=1008)\end{array}$ & $\begin{array}{l}\text { IFN beta-1a } 30 \mathrm{mcg} \\
\text { SC/week }+ \text { GA } 20 \mathrm{mg} \\
\text { SC/day vs IFN beta-1a } \\
30 \mathrm{mcg} \text { SC/week vs GA } \\
20 \mathrm{mg} \text { SC/day: volume } \\
\text { change }-1.73 \mathrm{~mL} \text { (SD } \\
22.63) \text { vs. }-0.71 \mathrm{~mL} \\
(17.01)-1.72 \mathrm{~mL}(15.66) ; \\
\text { differences were not } \\
\text { statistically significant }\end{array}$ & 36 months \\
\hline & CSF & $\begin{array}{l}\text { Lublin et al., Ann } \\
\text { Neurol } 2013 \\
\text { (CombiRx study) }\end{array}$ & $\begin{array}{l}\text { RRMS } \\
(n=1008)\end{array}$ & $\begin{array}{l}\text { IFN beta-1a } 30 \mathrm{mcg} \\
\text { SC/week + GA } 20 \mathrm{mg} \\
\text { SC/day vs IFN beta-1a } \\
30 \mathrm{mcg} \text { SC/week vs GA } \\
20 \mathrm{mg} \text { SC/day: percent } \\
\text { volume change } 0.60 \% \text { vs. } \\
0.51 \% \text { vs. } 0.57 \% \text { (ns; ns) } \\
\text { after } 36 \text { months } \\
\end{array}$ & 36 months \\
\hline & Thalamus & $\begin{array}{l}\text { Filippi et al., J Neurol } \\
\text { Neurosurg } \\
\text { Psychiatry. } 2013 \\
\text { (ALLEGRO study) }\end{array}$ & $\begin{array}{l}\text { RRMS } \\
(n=1106)\end{array}$ & $\begin{array}{l}\text { Laquinimod vs. Placebo, } \\
\text { median percent volume } \\
\text { change }-0.6 \% \text { vs. }-1.0 \% \\
\text { ( } p=0.005) \text { after } 12 \\
\text { months, }-0.7 \% \text { vs. }-0.9 \% \\
\text { ( } p=0.233 \text { ) between } 12 \\
\text { and } 24 \text { months, and }-1.3 \% \\
\text { vs. }-1.8 \% \text { ( } p=0.003)\end{array}$ & 24 months \\
\hline MTR & Whole brain & $\begin{array}{l}\text { Gold et al., NEJM } \\
\text { 2012; Arnold et al., J } \\
\text { Neurol } 2014 \\
\text { (DEFINE study) }\end{array}$ & $\begin{array}{l}\text { RRMS } \\
\text { ( } n=1234, \text { but } \\
\text { MRI cohort: } \\
n=540)\end{array}$ & $\begin{array}{l}\text { Dimethyl fumarate BID vs. } \\
\text { TID vs. placebo: percent } \\
\text { change: } \\
\text { BID: } 0.129 \%, p \text { (vs. } \\
\text { placebo) } 0.0027 ; \\
\text { TID: } 0.096 \%, p \text { (vs. } \\
\text { placebo) } 0.0051 ; \\
\text { Placebo: }-0.386 \% \\
\text { (reduction) after } 24 \\
\text { months }\end{array}$ & 24 months \\
\hline
\end{tabular}




\begin{tabular}{|c|c|c|c|c|c|}
\hline & & $\begin{array}{l}\text { Calabresi et al., } \\
\text { Lancet Neurol 2014; } \\
\text { Arnold et al., BMC } \\
\text { Neurol } 2014 \\
\text { (ADVANCE study) }\end{array}$ & \begin{tabular}{|l|} 
RRMS \\
$(n=1512)$
\end{tabular} & \begin{tabular}{|l|} 
Peginterferon beta- $1 a$ \\
every 4 vs. 2 weeks vs. \\
Placebo, percent change \\
$-0.432 \%$ ( $p=0.6873)$, and - \\
$0.129 \%$ ( $p=0.0438)$, vs. - \\
$0.382 \%$ after 1 year \\
\end{tabular} & 24 months \\
\hline & & $\begin{array}{l}\text { Filippi et al., J Neurol } \\
\text { Neurosurg } \\
\text { Psychiatry. } 2014 \\
\text { (ALLEGRO study) }\end{array}$ & $\begin{array}{l}\text { RRMS } \\
(n=1106)\end{array}$ & $\begin{array}{l}\text { Laquinimod vs. Placebo, } \\
\text { signal change } 0.31 \text { vs. - } \\
0.09(p=0.013) \text { after } 12 \\
\text { months, }-0.08 \text { vs. }-0.18 \\
(p=0.642) \text { between } 12 \\
\text { and } 24 \text { months, and } 0.23 \\
\text { vs. }-0.27(p=0.015) \text { after } \\
24 \text { months }\end{array}$ & 24 months \\
\hline & & $\begin{array}{l}\text { Miller et al., } \\
\text { Neurology } 2015 \\
\text { (CONFIRM study) }\end{array}$ & $\begin{array}{l}\text { RRMS } \\
(n=681)\end{array}$ & $\begin{array}{l}\text { Dimethyl Fumarate } \\
\text { 240mg BID and TID vs. } \\
\text { Glatiramer Acetate vs. } \\
\text { Placebo, percent change: } \\
-0.167 \text { (ns), }-0.008 \text { (ns), } \\
\text { and } 0.010 \text { (ns) vs. }-0.419 \\
\text { after } 2 \text { years }\end{array}$ & 24 months \\
\hline & White matter & $\begin{array}{l}\text { Filippi et al., J Neurol } \\
\text { Neurosurg } \\
\text { Psychiatry. } 2014 \\
\text { (ALLEGRO study) }\end{array}$ & $\begin{array}{l}\text { RRMS } \\
(n=1106)\end{array}$ & $\begin{array}{l}\text { Laquinimod vs. Placebo, } \\
\text { signal change } 0.32 \text { vs. - } \\
0.09(p=0.013) \text { after } 12 \\
\text { months, }-0.05 \text { vs. }-0.18 \\
\text { ( } p=0.486) \text { between } 12 \\
\text { and } 24 \text { months, and } 0.27 \\
\text { vs. }-0.27(p=0.011) \text { after } \\
24 \text { months } \\
\end{array}$ & 24 months \\
\hline & Grey matter & $\begin{array}{l}\text { Filippi et al., J Neurol } \\
\text { Neurosurg } \\
\text { Psychiatry. } 2014 \\
\text { (ALLEGRO study) }\end{array}$ & \begin{tabular}{|l|} 
RRMS \\
$(n=1106)$
\end{tabular} & $\begin{array}{l}\text { Laquinimod vs. Placebo, } \\
\text { signal change } 0.30 \text { vs. - } \\
0.11(p=0.014) \text { after } 12 \\
\text { months, }-0.16 \text { vs. }-0.22 \\
\text { ( } p=0.787) \text { between } 12 \\
\text { and } 24 \text { months, and } 0.14 \\
\text { vs. }-0.33(p=0.034) \text { after } \\
24 \text { months }\end{array}$ & 24 months \\
\hline & T2 lesions & $\begin{array}{l}\text { Filippi et al., J Neurol } \\
\text { Neurosurg } \\
\text { Psychiatry. } 2014 \\
\text { (ALLEGRO study) }\end{array}$ & $\begin{array}{l}\text { RRMS } \\
(n=1106)\end{array}$ & $\begin{array}{l}\text { Laquinimod vs. Placebo, } \\
\text { signal change } 0.39 \text { vs. } \\
0.02 \text { ( } p=0.239) \text { after } 12 \\
\text { months, } 0.07 \text { vs. }-0.08 \\
\text { ( } p=0.651) \text { between } 12 \\
\text { and } 24 \text { months, and } 0.46 \\
\text { vs. }-0.07 \text { ( } p=0.168) \text { after } \\
24 \text { months }\end{array}$ & 24 months \\
\hline $\begin{array}{l}\text { Proton MR } \\
\text { Spectroscopy }\end{array}$ & NAA/Cr value & $\begin{array}{l}\text { Filippi et al., J Neurol } \\
\text { Neurosurg } \\
\text { Psychiatry. 2014 } \\
\text { (ALLEGRO study) }\end{array}$ & \begin{tabular}{|l|} 
RRMS \\
$(n=1106)$
\end{tabular} & $\begin{array}{l}\text { Laquinimod vs. Placebo, } \\
\text { signal change } 0.047 \text { vs. - } \\
0.176(p=0.179) \text { after } 24 \\
\text { months }\end{array}$ & 24 months \\
\hline
\end{tabular}

Abbreviations: Gd: gadolinium; MTR: magnetisation transfer ratio; NAA/Cr: $\mathrm{N}$-acetyl aspartatecreatine ratio; RRMS: relapsing-remitting MS. 


\section{Table 5: Brain MRI outcome measures in phase III trials in CIS}

\section{Brain MRI}

Inclusion criteria: controlled phase III clinical trials

Exclusion criteria: incomplete data presentation (e.g. missing values); descriptive findings in absence of any statistical analysis; secondary analyses of clinical trials and extension studies evaluating the same clinical endpoints of the main trial in population subgroups or during longer observation time.

\begin{tabular}{|c|c|c|c|c|c|}
\hline $\begin{array}{l}\text { Original } \\
\text { neuroimaging } \\
\text { outcome }\end{array}$ & $\begin{array}{l}\text { Derived } \\
\text { outcome } \\
\text { measures }\end{array}$ & Trial & $\begin{array}{l}\text { Condition } \\
\text { (no. of } \\
\text { patients } \\
\text { randomised) }\end{array}$ & $\begin{array}{l}\text { Drug, effect } \\
\text { (vs. placebo/ another } \\
\text { active arm) }\end{array}$ & $\begin{array}{l}\text { Duration of } \\
\text { the trial }\end{array}$ \\
\hline \multirow[t]{6}{*}{ T2 lesions } & $\begin{array}{l}\text { Number of } \\
\text { new lesions }\end{array}$ & $\begin{array}{l}\text { Kappos et } \\
\text { al. } \\
\text { Neurology } \\
2006 ; \\
\text { Barkhof et } \\
\text { al. Ann } \\
\text { Neurol } \\
2007 \\
\text { (BENEFIT } \\
\text { study) }\end{array}$ & CIS (n=487) & $\begin{array}{l}\text { Interferon beta-1b vs. } \\
\text { Placebo, cumulative } \\
\text { number of lesions } 2.9 \text { vs. } \\
4.4 \text { up to the conversion to } \\
\text { MS ( } p<0.0001), 2.2 \text { vs. } 4.6 \\
\text { after } 2 \text { years }(p<0.001)\end{array}$ & 24 months \\
\hline & & $\begin{array}{l}\text { Comi et al. } \\
\text { Lancet } \\
2009 \\
\text { (PRECISE } \\
\text { study) } \\
\end{array}$ & CIS $(n=481)$ & $\begin{array}{l}\text { Glatiramer Acetate vs. } \\
\text { Placebo, number of lesions } \\
4.2 \text { vs. } 9.8(p<0.0001) \text { after } \\
2.32 \text { years }\end{array}$ & 36 months \\
\hline & $\begin{array}{l}\text { Number of } \\
\text { new or } \\
\text { enlarging } \\
\text { lesions }\end{array}$ & $\begin{array}{l}\text { Jacobs et } \\
\text { al. New } \\
\text { Eng J Med } \\
2000, \\
\text { Phase III } \\
\text { (CHAMPS } \\
\text { study) }\end{array}$ & CIS $(n=383)$ & $\begin{array}{l}\text { Interferon beta- } 1 \mathrm{a} 30 \mu \mathrm{g} \text { vs. } \\
\text { Placebo, number of lesions } \\
1.5 \text { vs. } 2.8 \text { after } 6 \text { months } \\
(p=0.01), 2.1 \text { vs. } 4.0 \text { after } \\
12 \text { months ( } p<0.001), 2.1 \\
\text { vs. } 5.0 \text { after } 18 \text { months } \\
(p<0.001)\end{array}$ & $\begin{array}{l}\text { Early } \\
\text { termination } \\
\text { due to } \\
\text { obvious } \\
\text { superiority } \\
\text { of IFN over } \\
\text { placebo } \\
\text { (initially } \\
\text { planned: } 36 \\
\text { months) }\end{array}$ \\
\hline & & $\begin{array}{l}\text { Comi et al. } \\
\text { Lancet } \\
2001, \\
\text { phase III } \\
\\
\\
\text { (ETOMS } \\
\text { study) }\end{array}$ & CIS $(n=309)$ & $\begin{array}{l}\text { Interferon beta-1a } 22 \mu \mathrm{g} \text { vs. } \\
\text { Placebo, median number } \\
\text { of lesions per patient per } \\
\frac{\text { scan } 2.0 \text { vs. } 3.0 \text { after } 2}{\text { years }(p<0.001)}\end{array}$ & 24 months \\
\hline & & $\begin{array}{l}\text { Leist et al. } \\
\text { Lancet } \\
\text { Neurol } \\
2014 \\
\text { (ORACLE } \\
\text { MS study) }\end{array}$ & CIS $(n=616)$ & $\begin{array}{l}\text { Cladribine } 5.25 \mathrm{mg} / \mathrm{Kg} \text { or } \\
3.5 \mathrm{mg} / \mathrm{Kg} \text {, vs. Placebo, } \\
\text { median cumulative number } \\
\text { of lesions } 0.0 \text { or } 0.0 \text { vs. } 2.0 \\
\text { after } 96 \text { weeks ( } p<0.001 \text { ) }\end{array}$ & 96 weeks \\
\hline & $\begin{array}{l}\text { Lesion } \\
\text { volume }\end{array}$ & $\begin{array}{l}\text { Miller et } \\
\text { al. Lancet } \\
\text { Neurol } \\
2014 \\
\end{array}$ & CIS $(n=618)$ & $\begin{array}{l}\text { Teriflunomide } 14 \mathrm{mg} \text { vs. } \\
7 \mathrm{mg} \text { vs. Placebo, volume } \\
\text { change }-0.028 \mathrm{~mL} \\
(\mathrm{p}=0.0374) \text { vs. } 0.023 \mathrm{~mL}\end{array}$ & 108 weeks \\
\hline
\end{tabular}




\begin{tabular}{|c|c|c|c|c|c|}
\hline & & $\begin{array}{l}\text { (TOPIC } \\
\text { study) }\end{array}$ & & $\begin{array}{l}(p=0.7789) \text { vs. } 0.044 \mathrm{~mL} \\
\text { after } 108 \text { weeks }\end{array}$ & \\
\hline & $\begin{array}{l}\text { Volume of T2 } \\
\text { lesions }\end{array}$ & $\begin{array}{l}\text { Jacobs et } \\
\text { al. New } \\
\text { Eng J Med } \\
2000 \\
\text { (CHAMPS } \\
\text { study) }\end{array}$ & $\operatorname{CIS}(n=383)$ & $\begin{array}{l}\text { Interferon beta- } 1 \text { a } 30 \mu g \text { vs. } \\
\text { Placebo, median volume } \\
\text { change }-123 \mathrm{~mm}^{3} \text { vs. } \\
40 \mathrm{~mm}^{3} \text { after } 6 \mathrm{months}^{3} \\
(\mathrm{p}<0.001), 102 \mathrm{~mm}^{3} \text { vs. } \\
214 \mathrm{~mm}^{3} \text { after } 12 \text { months } \\
(p=0.004), 28 \mathrm{~mm}^{3} \text { vs. } \\
313 \mathrm{~mm}^{3} \text { after } 18 \text { months } \\
(p<0.001)\end{array}$ & $\begin{array}{l}\text { Early } \\
\text { termination: } \\
\text { obvious } \\
\text { superiority } \\
\text { of IFN over } \\
\text { placebo } \\
\text { (initially } \\
\text { planned: } 36 \\
\text { months) }\end{array}$ \\
\hline & & $\begin{array}{l}\text { Comi et al. } \\
\text { Lancet } \\
2001 \\
\text { (ETOMS } \\
\text { study) }\end{array}$ & CIS $(n=309)$ & $\begin{array}{l}\text { Interferon beta- } 1 \text { a } 22 \mu \mathrm{g} \text { vs. } \\
\text { Placebo, median volume } \\
\text { change }-487 \mathrm{~mm}^{3} \text { vs. - } \\
299 \mathrm{~mm}^{3} \text { after } 2 \text { years } \\
(p=0.002) ; \text { median percent } \\
\text { volume change }-13.0 \% \text { vs. } \\
\begin{array}{l}8.8 \% \text { after } 2 \text { years } \\
(p=0.002)\end{array}\end{array}$ & 24 months \\
\hline & & $\begin{array}{l}\text { Kappos et } \\
\text { al. } \\
\text { Neurology } \\
2006 ; \\
\text { Barkhof et } \\
\text { al. Ann } \\
\text { Neurol } \\
2007 \\
\text { (BENEFIT } \\
\text { study) }\end{array}$ & CIS $(n=487)$ & $\begin{array}{l}\text { Interferon beta- } 1 \mathrm{~b} \text { vs. } \\
\text { Placebo, volume change - } \\
888.5 \mathrm{~mm}^{3} \text { vs. }-431.6 \mathrm{~mm}^{3} \\
\text { up to the conversion to } \mathrm{MS} \\
(\mathrm{p}<0.05),-1.0 \mathrm{~cm}^{3} \text { vs. - } \\
0.3 \mathrm{~cm}^{3} \text { after } 2 \text { years } \\
(p=0.02)\end{array}$ & 24 months \\
\hline & & $\begin{array}{l}\text { Miller et } \\
\text { al. Lancet } \\
\text { Neurol } \\
2014 \\
\text { (TOPIC } \\
\text { study) } \\
\end{array}$ & $\operatorname{CIS}(n=618)$ & $\begin{array}{l}\text { Teriflunomide } 14 \mathrm{mg} \text { vs. } \\
7 \mathrm{mg} \text { vs. Placebo, volume } \\
\text { change }-0.029 \mathrm{~mL} \\
(p=0.0503) \text { vs. } 0.022 \mathrm{~mL} \\
(p=0.7360) \text { vs. } 0.045 \mathrm{~mL} \\
\text { after } 108 \text { weeks }\end{array}$ & 108 weeks \\
\hline \multirow[t]{3}{*}{$\begin{array}{l}\text { Gd- } \\
\text { enhancing } \\
\text { lesions }\end{array}$} & $\begin{array}{l}\text { Number of } \\
\text { Gd- } \\
\text { enhancing } \\
\text { lesions }\end{array}$ & $\begin{array}{l}\text { Jacobs et } \\
\text { al. New } \\
\text { Eng J Med } \\
2000 \\
\text { (CHAMPS } \\
\text { study) }\end{array}$ & $\operatorname{CIS}(n=383)$ & $\begin{array}{l}\text { Interferon beta- } 1 \mathrm{a} 30 \mu \mathrm{g} \text { vs. } \\
\text { Placebo, number of lesions } \\
0.9 \text { vs. } 1.5 \text { after } 6 \text { months } \\
\text { ( } p=0.03), 0.7 \text { vs. } 1.6 \text { after } \\
12 \text { months ( } p=0.02), 0.4 \text { vs. } \\
1.4 \text { after } 18 \text { months } \\
(p<0.001)\end{array}$ & $\begin{array}{l}\text { Early } \\
\text { termination: } \\
\text { obvious } \\
\text { superiority } \\
\text { of IFN over } \\
\text { placebo } \\
\text { (initially } \\
\text { planned: } 36 \\
\text { months) }\end{array}$ \\
\hline & & $\begin{array}{l}\text { Comi et al. } \\
\text { Lancet } \\
2001 \\
\text { (ETOMS } \\
\text { study) }\end{array}$ & $\operatorname{CIS}(n=309)$ & $\begin{array}{l}\text { Interferon beta- } 1 \text { a } 22 \mu \mathrm{g} \text { vs. } \\
\text { Placebo, median number } \\
\text { of lesions per patient per } \\
\text { scan } 0.5 \text { vs. } 0.0 \text { after } 2 \\
\text { years ( } p=0.809)\end{array}$ & 24 months \\
\hline & & $\begin{array}{l}\text { Kappos et } \\
\text { al. } \\
\text { Neurology } \\
\text { 2006; } \\
\text { Barkhof et } \\
\text { al. Ann } \\
\text { Neurol }\end{array}$ & $\operatorname{CIS}(n=487)$ & $\begin{array}{l}\text { Interferon beta-1b vs. } \\
\text { Placebo, cumulative } \\
\text { number of lesions } 1.9 \text { vs. } \\
4.3 \text { up to conversion to MS } \\
\text { ( } p<0.0001), 2.2 \text { vs. } 4.6 \text { after } \\
2 \text { years ( } p<0.001) ; \text { new } \\
\text { lesions per scan } 0.4 \text { vs. } 1.0\end{array}$ & 24 months \\
\hline
\end{tabular}




\begin{tabular}{|c|c|c|c|c|c|}
\hline & & \begin{tabular}{|l|}
2007 \\
(BENEFIT \\
study)
\end{tabular} & & after 2 years $(p<0.001)$ & \\
\hline & & $\begin{array}{l}\text { Leist et al. } \\
\text { Lancet } \\
\text { Neurol } \\
2014 \\
\text { (ORACLE } \\
\text { MS study) }\end{array}$ & CIS $(n=616)$ & $\begin{array}{l}\text { Cladribine } 5.25 \mathrm{mg} / \mathrm{Kg} \text { or } \\
3.5 \mathrm{mg} / \mathrm{Kg} \text {, vs. Placebo, } \\
\text { median cumulative number } \\
\text { of lesions } 0.0 \text { or } 0.0 \text { vs. } 2.0 \\
\text { after } 96 \text { weeks ( } p<0.001 \text { ) }\end{array}$ & 96 weeks \\
\hline & & $\begin{array}{l}\text { Miller et } \\
\text { al. Lancet } \\
\text { Neurol } \\
2014 \\
\text { (TOPIC } \\
\text { study) }\end{array}$ & CIS $(\mathrm{n}=618)$ & $\begin{array}{l}\text { Teriflunomide } 14 \mathrm{mg} \text { vs. } \\
7 \mathrm{mg} \text { vs. Placebo, number } \\
\text { of lesions per scan } 0.395 \\
(p=0.0008) \text { vs. } 0.749 \\
(p=0.4436) \text { vs. } 0.953 \text { after } \\
108 \text { weeks }\end{array}$ & 108 weeks \\
\hline & $\begin{array}{l}\text { Volume of } \\
\text { Gd- } \\
\text { enhancing } \\
\text { lesions }\end{array}$ & \begin{tabular}{|l|} 
Kappos et \\
al. \\
Neurology \\
$2006 ;$ \\
Barkhof et \\
al. Ann \\
Neurol \\
2007 \\
(BENEFIT \\
study)
\end{tabular} & CIS ( $n=487)$ & $\begin{array}{l}\text { Interferon beta- } 1 \mathrm{~b} \text { vs. } \\
\text { Placebo, cumulative } \\
\text { volume of lesions } \\
203.5 \mathrm{~mm}^{3} \text { vs. } 520.6 \mathrm{~mm}^{3} \\
\text { up to conversion to } \mathrm{MS} \\
(\mathrm{p}<0.0001), 0.2 \mathrm{~cm}^{3} \text { vs. } \\
0.5 \mathrm{~cm}^{3} \text { after } 2 \text { years } \\
(p<0.001) ; \text { volume of } \\
\text { lesions per scan } 0.1 \mathrm{~cm}^{3} \text { vs. } \\
0.1 \mathrm{~cm}^{3} \text { after } 2 \text { years } \\
(p<0.001)\end{array}$ & 24 months \\
\hline & & \begin{tabular}{|l|} 
Miller et \\
al. Lancet \\
Neurol \\
2014 \\
(TOPIC \\
study)
\end{tabular} & CIS (n=618) & $\begin{array}{l}\text { Teriflunomide } 14 \mathrm{mg} \text { vs. } \\
7 \mathrm{mg} \text { vs. Placebo, volume } \\
\text { change } 0.034 \mathrm{~mL}(p<0.0001) \\
\text { vs. } 0.058 \mathrm{~mL}(p=0.0077) \text { vs. } \\
0.079 \mathrm{~mL} \text { after } 108 \text { weeks }\end{array}$ & 108 weeks \\
\hline \multirow[t]{4}{*}{ T1 lesions } & $\begin{array}{l}\text { New T1 } \\
\text { lesions }\end{array}$ & \begin{tabular}{|l} 
Kappos et \\
al. \\
Neurology \\
2006; \\
Barkhof et \\
al. Ann \\
Neurol \\
2007 \\
(BENEFIT \\
study)
\end{tabular} & CIS $(n=487)$ & $\begin{array}{l}\text { Interferon beta- } 1 \mathrm{~b} \text { vs. } \\
\text { Placebo, cumulative } \\
\text { number of lesions } 0.2 \text { vs. } \\
0.3 \text { after } 2 \text { years }(p<0.001)\end{array}$ & 24 months \\
\hline & & $\begin{array}{l}\text { lomi et al. } \\
\text { Lancet } \\
2009, \\
\text { phase III }{ }^{10} \\
\text { (PRECISE } \\
\text { study) } \\
\end{array}$ & CIS $(n=481)$ & $\begin{array}{l}\text { Glatiramer Acetate vs. } \\
\text { Placebo, cumulative } \\
\text { number of lesions } 1.7 \text { vs. } \\
3.6(p<0.0001) \text { after } 2.32 \\
\text { years }\end{array}$ & 36 months \\
\hline & $\begin{array}{l}\text { Volume of T1 } \\
\text { lesions }\end{array}$ & $\begin{array}{l}\text { Miller et } \\
\text { al. Lancet } \\
\text { Neurol } \\
2014 \\
\text { (TOPIC } \\
\text { study) }\end{array}$ & CIS $(n=618)$ & $\begin{array}{l}\text { Teriflunomide } 14 \mathrm{mg} \text { vs. } \\
7 \mathrm{mg} \text { vs. Placebo, volume } \\
\text { change }-0.016 \mathrm{~mL} \\
(p=0.0120) \text { vs. } 0.015 \mathrm{~mL} \\
(p=0.9100) \text { vs. } 0.014 \mathrm{~mL} \\
\text { after } 108 \text { weeks }\end{array}$ & 108 weeks \\
\hline & & $\begin{array}{l}\text { Kappos et } \\
\text { al. }\end{array}$ & CIS (n=487) & $\begin{array}{l}\text { Interferon beta- } 1 \mathrm{~b} \text { vs. } \\
\text { Placebo, change in volume }\end{array}$ & 24 months \\
\hline
\end{tabular}




\begin{tabular}{|c|c|c|c|c|c|}
\hline & & \begin{tabular}{|l} 
Neurology \\
2006; \\
Barkhof et \\
al. Ann \\
Neurol \\
2007 \\
(BENEFIT \\
study)
\end{tabular} & & $\begin{array}{l}\text { of lesions }-0.0 \mathrm{~cm}^{3} \text { vs. - } \\
0.1 \mathrm{~cm}^{3} \text { after } 2 \text { years } \\
(\mathrm{p}=0.29)\end{array}$ & \\
\hline \multirow[t]{4}{*}{$\begin{array}{l}\text { Combined } \\
\text { measures }\end{array}$} & $\begin{array}{l}\text { Combined } \\
\text { unique } \\
\text { lesions }\end{array}$ & \begin{tabular}{|l} 
Comi et al. \\
Lancet \\
2001 \\
(ETOMS \\
study)
\end{tabular} & CIS $(\mathrm{n}=309)$ & $\begin{array}{l}\text { Interferon beta- } 1 \text { a } 22 \mu \mathrm{g} \text { vs. } \\
\text { Placebo, proportion of } \\
\text { patients without lesions } \\
16 \% \text { vs. } 6 \% \text { after } 2 \text { years } \\
(\mathrm{p}=0.005)\end{array}$ & 24 months \\
\hline & & \begin{tabular}{|l} 
Kappos et \\
al. \\
Neurology \\
$2006 ;$ \\
Barkhof et \\
al. Ann \\
Neurol \\
2007 \\
(BENEFIT \\
study)
\end{tabular} & CIS $(n=487)$ & $\begin{array}{l}\text { Interferon beta- } 1 \mathrm{~b} \text { vs. } \\
\text { Placebo, cumulative } \\
\text { number of lesions } 3.7 \text { vs. } \\
8.5 \text { up to the conversion to } \\
\text { MS ( } p<0.001), 5.7 \text { vs. } 10.3 \\
\text { after } 2 \text { years ( } p<0.001 \text { ) }\end{array}$ & 24 months \\
\hline & & $\begin{array}{l}\text { Comi et al. } \\
\text { Lancet } \\
\text { Neurol } \\
2012 \\
\text { (REFLEX } \\
\text { study) }\end{array}$ & CIS $(n=517)$ & $\begin{array}{l}\text { Interferon beta- } 1 \text { a three } \\
\text { times a week vs. once a } \\
\text { week vs. Placebo, number } \\
\text { of lesions per patient per } \\
\text { scan } 0.60 \text { vs. } 1.23 \text { vs. } 2.70 \\
(p<0.0001 ; p<0.0001 ; \\
p=0.0015) \text { after } 2 \text { years }\end{array}$ & 108 weeks \\
\hline & & $\begin{array}{l}\text { Leist et al. } \\
\text { Lancet } \\
\text { Neurol } \\
2014 \\
\text { (ORACLE } \\
\text { MS study) }\end{array}$ & CIS $(n=616)$ & $\begin{array}{l}\text { Cladribine } 5.25 \mathrm{mg} / \mathrm{Kg} \text { or } \\
3.5 \mathrm{mg} / \mathrm{Kg} \text {, vs. Placebo, } \\
\text { median cumulative number } \\
\text { of lesions } 1.0 \text { or } 1.0 \text { vs. } 4.0 \\
\text { after } 96 \text { weeks ( } p<0.001 \text { ) }\end{array}$ & 96 weeks \\
\hline \multirow[t]{2}{*}{ Brain atrophy } & $\begin{array}{l}\text { Brain } \\
\text { parenchymal } \\
\text { fraction }\end{array}$ & $\begin{array}{l}\text { Comi et al. } \\
\text { Lancet } \\
2009 \\
\text { (PRECISE } \\
\text { study) } \\
\end{array}$ & $\operatorname{CIS}(n=481)$ & $\begin{array}{l}\text { Glatiramer Acetate vs. } \\
\text { Placebo, percent volume } \\
\text { change }-0.33 \% \text { vs. }-0.38 \% \\
\text { (ns) }\end{array}$ & 36 months \\
\hline & & $\begin{array}{l}\text { Miller et } \\
\text { al. Lancet } \\
\text { Neurol } \\
2014 \\
\text { (TOPIC } \\
\text { study) }\end{array}$ & CIS (n=618) & $\begin{array}{l}\text { Teriflunomide } 14 \mathrm{mg} \text { vs. } \\
7 \mathrm{mg} \text { vs. Placebo, volume } \\
\text { change }-0.008 \mathrm{~mL} \\
(\mathrm{p}=0.4495) \text { vs. }-0.002 \mathrm{~mL} \\
(\mathrm{p}=0.4462) \text { vs. }-0.003 \mathrm{~mL} \\
\text { after } 108 \text { weeks }\end{array}$ & 108 weeks \\
\hline
\end{tabular}

Abbreviations: Gd: gadolinium; CIS: clinically isolated syndrome. 
Table 6: Brain MRI outcome measures in phase III trials in progressive MS

Brain MRI

Inclusion criteria: controlled phase III clinical trials

Exclusion criteria: incomplete data presentation (e.g. missing values); descriptive findings in absence of any statistical analysis; secondary analyses of clinical trials and extension studies evaluating the same clinical endpoints of the main trial in population subgroups or during longer observation time.

\begin{tabular}{|c|c|c|c|c|c|}
\hline $\begin{array}{l}\text { Original } \\
\text { neuroimaging } \\
\text { outcome }\end{array}$ & $\begin{array}{l}\text { Derived outcome } \\
\text { measures }\end{array}$ & Trial & $\begin{array}{l}\text { Condition (no. of } \\
\text { patients } \\
\text { randomised) }\end{array}$ & $\begin{array}{l}\text { Drug, effect } \\
\text { (vs. placebo/ } \\
\text { another active } \\
\text { arm) }\end{array}$ & $\begin{array}{l}\text { Duration of the } \\
\text { trial }\end{array}$ \\
\hline \multirow[t]{4}{*}{ T2 lesions } & $\begin{array}{l}\text { Number of new } \\
\text { or enlarging } \\
\text { lesions }\end{array}$ & $\begin{array}{l}\text { Secondary } \\
\text { Progressive } \\
\text { Efficacy Clinical } \\
\text { Trial of } \\
\text { Recombinant } \\
\text { Interferon-beta- } \\
\text { 1a in MS } \\
\text { (SPECTRIMS) } \\
\text { Study Group; Li et } \\
\text { al., Neurology } \\
2001 \text { (SPECTRIMS } \\
\text { study) }\end{array}$ & SPMS (n=618) & $\begin{array}{l}\text { IFN beta-1a } 44 \mu \mathrm{g} \\
\text { vs. IFN beta-1a } \\
22 \mu \mathrm{g} \text { vs. placebo: } \\
\text { median number } \\
\text { lesions per } \\
\text { patient per scan: } \\
0.17,0.20 \text { and } \\
0.67, \text { respectively, } \\
p<0.0001 \text { (all } \\
\text { comparisons with } \\
\text { placebo) }\end{array}$ & 36 months \\
\hline & & $\begin{array}{l}\text { Cohen et al., } \\
\text { Neurology } 2002 \\
\text { (IMPACT study) }\end{array}$ & SPMS $(n=436)$ & $\begin{array}{l}\text { IFN beta-1a } \\
60 \mathrm{mcg} / \text { week IM } \\
\text { vs. placebo: mean } \\
\text { number of lesions } \\
\text { was reduced } \\
45.6 \% \text { in the IFN- } \\
1 \text { a group relative } \\
\text { to the placebo } \\
\text { group at month } \\
24\end{array}$ & 24 months \\
\hline & & $\begin{array}{l}\text { Hommes et al., } \\
\text { Lancet Neurol } \\
\text { 2004; Fazekas et } \\
\text { al., Mult Scler } \\
2005 \text { (ESIMS } \\
\text { study) }\end{array}$ & SPMS $(n=612)$ & $\begin{array}{l}\text { Intravenous } \\
\text { Immunoglobulin } \\
\text { vs. Placebo, } \\
\text { number of lesions } \\
2.67 \text { vs. } 3.44 \text { after } \\
1 \text { year (ns), } 2.45 \\
\text { vs. } 3.01 \text { after } 2 \\
\text { years (ns), } 4.94 \\
\text { vs. } 6.44 \text { overall } \\
\text { ( } p=0.06)\end{array}$ & 24 months \\
\hline & & $\begin{array}{l}\text { Freedman et al., } \\
\text { Neurology } 2011 \\
\text { (MAESTRO study) }\end{array}$ & SPMS $(n=612)$ & $\begin{array}{l}\text { MBP8298 vs. } \\
\text { Placebo, } \\
\text { cumulative } \\
\text { number of lesions } \\
\text { among DR2 } 2^{+} \text {or } \\
\text { DR4 }{ }^{+} 1.9 \text { vs. } 1.8 \\
\text { after } 12 \text { months } \\
\text { (p=0.034), among } \\
\text { DR2 } / \text { DR4 } 1.7 \text { vs. } \\
2.0 \text { after } 12\end{array}$ & 24 months \\
\hline
\end{tabular}




\begin{tabular}{|c|c|c|c|c|}
\hline & & & months $(p=0.828)$ & \\
\hline & $\begin{array}{l}\text { Zajicek et al., } \\
\text { Lancet Neurol } \\
2013 \text { (CUPID } \\
\text { study) }\end{array}$ & $\begin{array}{l}\text { PPMS ( } n=191) \text {, } \\
\text { SPMS ( } n=302) \\
\text { (received } \\
\text { treatment: } n=493 ; \\
\text { randomised: } \\
n=498 \text { ) }\end{array}$ & $\begin{array}{l}\text { Dronabinol vs. } \\
\text { Placebo, } \\
\text { proportion of } \\
\text { patients with } \\
\frac{\text { lesions } 37 \% \text { vs. }}{40 \% \text { after } 3 \text { years }} \\
(p=0.70)\end{array}$ & 36 months \\
\hline & $\begin{array}{l}\text { Lublin et al., } \\
\text { Lancet } 2016 \\
\text { (INFORMS study) }\end{array}$ & PPMS (n=970) & $\begin{array}{l}\text { Fingolimod } 0.5 \mathrm{mg} \\
\text { vs. Placebo, lesion } \\
\text { number per year } \\
0.13 \text { vs. } 0.50 \% \\
(p<0.001) ; \\
\text { number of } \\
\text { patients free of } \\
\text { lesions } 80 \% \text { vs. } \\
\begin{array}{l}60 \%(p<0.001) \\
\text { after } 36 \text { months }\end{array}\end{array}$ & 36 months \\
\hline $\begin{array}{l}\text { Volume of T2 } \\
\text { lesions }\end{array}$ & $\begin{array}{l}\text { European Study } \\
\text { Group on } \\
\text { Interferon beta- } \\
\text { 1b in Secondary } \\
\text { Progressive MS, } \\
\text { Lancet } 1998 \\
\text { (EUSPMS study) }\end{array}$ & SPMS (n=718) & $\begin{array}{l}\text { Interferon beta- } \\
1 \mathrm{~b} \text { vs. Placebo, } \\
\text { percent lesion } \\
\text { volume change - } \\
5 \% \text { vs. } 8 \% \\
(p<0.0001) \text { after } 3 \\
\text { years }\end{array}$ & $\begin{array}{l}\text { Early termination: } \\
\text { obvious } \\
\text { superiority of IFN } \\
\text { vs. placebo } \\
\text { (initially planned: } \\
39 \text { months) }\end{array}$ \\
\hline & $\begin{array}{l}\text { Secondary } \\
\text { Progressive } \\
\text { Efficacy Clinical } \\
\text { Trial of } \\
\text { Recombinant } \\
\text { Interferon-beta- } \\
\text { 1a in MS } \\
\text { (SPECTRIMS) } \\
\text { Study Group; Li et } \\
\text { al., Neurology } \\
2001 \text { (SPECTRIMS } \\
\text { study) }\end{array}$ & SPMS (n=618) & $\begin{array}{l}\text { IFN beta-1a } 44 \mu \mathrm{g} \\
\text { vs. IFN beta-1a } \\
22 \mu \mathrm{g} \text { vs. placebo: } \\
\text { Median change in } \\
\text { burden of disease } \\
\text { (in mm2, i.e. sum } \\
\text { of lesional area } \\
\text { per patient and } \\
\text { scan, as an } \\
\text { indirect measure } \\
\text { of T2 lesion } \\
\text { volume): }-32 \text { vs. - } \\
4 \text { vs. }+263, \\
\text { respectively, } \\
\text { p<0.0001 for } \\
\text { comparisons of } \\
\text { both doses vs. } \\
\text { placebo }\end{array}$ & 36 months \\
\hline & $\begin{array}{l}\text { Cohen et al., } \\
\text { Neurology } 2002 \\
\text { (IMPACT study) }\end{array}$ & SPMS (n=436) & $\begin{array}{l}\text { IFN beta-1a } \\
60 \mathrm{mcg} / \text { week IM } \\
\text { vs. placebo: } \\
\text { Median change in } \\
\frac{\text { total T2- }}{\text { hyperintense }} \\
\frac{\text { lesion volume }}{\text { (from baseline) }} \\
\text { was reduced in } \\
\text { the IFNb-1a group } \\
\text { compared to the }\end{array}$ & 24 months \\
\hline
\end{tabular}




\begin{tabular}{|c|c|c|c|c|c|}
\hline & & & & $\begin{array}{l}\text { placebo group by } \\
69.1 \% \text { at month } \\
24(p<0.001)\end{array}$ & \\
\hline & & $\begin{array}{l}\text { Hommes et al., } \\
\text { Lancet Neurol } \\
\text { 2004; Fazekas et } \\
\text { al., Mult Scler } \\
2005 \text { (ESIMS } \\
\text { study) }\end{array}$ & SPMS $(n=318)$ & $\begin{array}{l}\text { Intravenous } \\
\text { Immunoglobulin } \\
\text { vs. Placebo, lesion } \\
\text { volume } 25.44 \mathrm{~cm}^{3} \\
\text { vs. } 24.98 \mathrm{~cm}^{3} \text { after } \\
1 \text { year (ns), } \\
25.17 \mathrm{~cm}^{3} \text { vs. } \\
23.66 \mathrm{~cm}^{3} \text { after } 2 \\
\text { years (ns) }\end{array}$ & 24 months \\
\hline & & $\begin{array}{l}\text { The North } \\
\text { American Study } \\
\text { Group on } \\
\text { Interferon beta- } \\
1 \text { b in Secondary } \\
\text { Progressive MS } \\
\text { Neurology } 2004 \\
\text { (NASPMS study) }\end{array}$ & SPMS (n=939) & $\begin{array}{l}\text { Interferon beta- } \\
1 \mathrm{~b} 250 \mu \mathrm{g} \text { or } \\
160 \mu \mathrm{g} \text { vs. } \\
\text { Placebo, median } \\
\text { percent change in } \\
\text { annual lesion area } \\
0.4 \%(\mathrm{p}<0.001), \\
0.8 \%(\mathrm{p}<0.001), \\
\text { vs. } 10.9 \% \text { after } 3 \\
\text { years }\end{array}$ & $\begin{array}{l}\text { Early termination } \\
\text { for futility } \\
\text { (initially planned: } \\
36 \text { months) }\end{array}$ \\
\hline & & $\begin{array}{l}\text { Wolinsky et al., } \\
\text { Ann Neurol } 2007 \\
\text { (PROMISE study) }\end{array}$ & PPMS (n=943) & $\begin{array}{l}\text { Glatiramer } \\
\text { acetate vs. } \\
\text { Placebo, percent } \\
\text { volume change- } \\
39 \% \text { after } 1 \text { year } \\
(\mathrm{p}=0.1716),-71 \% \\
\text { after } 2 \text { years } \\
(\mathrm{p}=0.0026) \text {, and }- \\
58 \% \text { after } 3 \text { years } \\
(\mathrm{p}=0.1344)\end{array}$ & 36 months \\
\hline & & $\begin{array}{l}\text { Hawker et al., Ann } \\
\text { Neurol } 2009 \\
\text { (OLYMPUS study) }\end{array}$ & PPMS ( $n=439)$ & $\begin{array}{l}\begin{array}{l}\text { Rituximab vs. } \\
\text { Placebo, volume } \\
\text { change } 2205 \mathrm{~mm}^{3} \\
\text { vs. } 1507 \mathrm{~mm}^{3} \\
(p<0.001) \text { after } 96 \\
\text { weeks }\end{array}\end{array}$ & 96 weeks \\
\hline & & $\begin{array}{l}\text { Freedman et al., } \\
\text { Neurology } 2011 \\
\text { (MAESTRO study) }\end{array}$ & SPMS ( $n=612)$ & $\begin{array}{l}\text { MBP8298 vs. } \\
\text { Placebo, median } \\
\text { volume change } \\
\text { among DR2 }{ }^{+} \text {or } \\
\text { DR4 } 417.5 \mathrm{~mm}^{3} \\
\text { vs. } 491.5 \mathrm{~mm}^{3} \\
\text { after } 24 \text { months } \\
(p=0.802) \text {, among } \\
\text { DR2 } / \mathrm{DR4}^{-} \\
684.8 \mathrm{~mm}^{3} \text { vs. } \\
738.0 \mathrm{~mm}^{3} \text { after } \\
24 \text { months } \\
(p=0.873)\end{array}$ & 24 months \\
\hline & & $\begin{array}{l}\text { Montalban et al., } \\
\text { N Engl J Med. }\end{array}$ & PPMS (n=732) & $\begin{array}{l}\text { Ocrelizumab } \\
600 \mathrm{mg}(300 \mathrm{mg}\end{array}$ & 120 weeks \\
\hline
\end{tabular}




\begin{tabular}{|c|c|c|c|c|c|}
\hline & & $\begin{array}{l}2016 \text { (ORATORIO } \\
\text { study) }\end{array}$ & & $\begin{array}{l}\text { x2) / } 24 \text { weeks IV } \\
\text { vs. placebo: } \\
\text { percent volume } \\
\text { change: }-3.4 \% \text { vs. } \\
+7.4 \%(p<0.0001)\end{array}$ & \\
\hline \multirow[t]{5}{*}{$\begin{array}{l}\text { Gd-enhancing } \\
\text { lesions }\end{array}$} & $\begin{array}{l}\text { Number of Gd- } \\
\text { enhancing lesions }\end{array}$ & $\begin{array}{l}\text { Hommes et al., } \\
\text { Lancet Neurol } \\
\text { 2004; Fazekas et } \\
\text { al., MSJ } 2005 \\
\text { (ESIMS study) }\end{array}$ & SPMS (=318) & $\begin{array}{l}\text { Intravenous } \\
\text { Immunoglobulin } \\
\text { vs. Placebo, } \\
\text { number of lesions } \\
1.62 \text { vs. } 1.47 \text { after } \\
1 \text { year (ns), } 1.14 \\
\text { vs. } 0.86 \text { after } 2 \\
\text { years (ns), } 2.47 \\
\text { vs. } 2.32 \text { overall } \\
\text { (ns); percent of } \\
\text { enhancing scans } \\
35.2 \% \text { vs. } 45.3 \% \\
\text { after } 1 \text { year (ns), } \\
32.1 \% \text { vs. } 28.3 \% \\
\text { after } 2 \text { years (ns) }\end{array}$ & 24 months \\
\hline & & $\begin{array}{l}\text { The North } \\
\text { American Study } \\
\text { Group on } \\
\text { Interferon beta- } \\
1 \text { b in Secondary } \\
\text { Progressive MS } \\
\text { Neurology } 2004 \\
\text { (NASPMS study) }\end{array}$ & SPMS ( $n=939)$ & $\begin{array}{l}\text { Interferon beta- } \\
1 \mathrm{~b} 250 \mu \mathrm{g} \text { or } \\
160 \mu \mathrm{g} \text { vs. } \\
\text { Placebo, annual } \\
\text { new active lesion } \\
\text { rate } 6.4 \\
(\mathrm{p}<0.001), 4.5 \\
(\mathrm{p}<0.001), \text { vs. } 18.7 \\
\text { after } 3 \text { years }\end{array}$ & $\begin{array}{l}\text { Early termination } \\
\text { for futility } \\
\text { (initially planned: } \\
36 \text { months) }\end{array}$ \\
\hline & & $\begin{array}{l}\text { Wolinsky et al., } \\
\text { Ann Neurol } 2007 \\
\text { (PROMISE study) }\end{array}$ & PPMS ( $n=943)$ & $\begin{array}{l}\text { Glatiramer } \\
\text { acetate vs. } \\
\text { Placebo, percent } \\
\text { change }-89 \% \text { after } \\
1 \text { year }(p=0.0022), \\
-47 \% \text { after } 2 \text { years } \\
(p=0.0702) \text {, and - } \\
6 \% \text { after } 3 \text { years } \\
(p=0=8387)\end{array}$ & 36 months \\
\hline & & $\begin{array}{l}\text { Freedman et al., } \\
\text { Neurology } 2011 \\
\text { (MAESTRO study) }\end{array}$ & SPMS ( $n=612)$ & $\begin{array}{l}\text { MBP8298 vs. } \\
\text { Placebo, lesion } \\
\text { change among } \\
\text { DR2 }{ }^{+} \text {or DR4 } 1.1 \\
\text { vs. } 0.8 \text { after } 12 \\
\text { months } \\
(p=0.427) \text {, among } \\
\text { DR2 } / \text { DR4 } 0.9 \text { vs. } \\
1.0 \text { after } 12 \\
\text { months ( } p=0.765)\end{array}$ & 24 months \\
\hline & & $\begin{array}{l}\text { Lublin et al., } \\
\text { Lancet } 2016 \\
\text { (INFORMS study) }\end{array}$ & PPMS ( $n=970)$ & $\begin{array}{l}\text { Fingolimod } 0.5 \mathrm{mg} \\
\text { vs. Placebo, lesion } \\
\text { number per scan } \\
0.05 \text { vs. } 0.21 \\
(p<0.001) \text { after } 36 \\
\text { months }\end{array}$ & 36 months \\
\hline
\end{tabular}




\begin{tabular}{|c|c|c|c|c|c|}
\hline & $\begin{array}{l}\text { Number of } \\
\text { patients with Gd- } \\
\text { enhancing lesions }\end{array}$ & $\begin{array}{l}\text { Lublin et al., } \\
\text { Lancet } 2016 \\
\text { (INFORMS study) }\end{array}$ & PPMS (n=970) & $\begin{array}{l}\text { Fingolimod } 0.5 \mathrm{mg} \\
\text { vs. Placebo, } \\
\text { percentage of } \\
\text { patients free of } \\
\text { lesions } 87 \% \text { vs. } \\
78 \%(p=0.006) \\
\text { after } 36 \text { months }\end{array}$ & 36 months \\
\hline \multirow[t]{4}{*}{ T1 lesions } & New T1 lesions & $\begin{array}{l}\text { Zajicek et al., } \\
\text { Lancet Neurol } \\
2013 \text { (CUPID } \\
\text { study) }\end{array}$ & $\begin{array}{l}\text { PPMS }(n=191) \\
\text { SPMS ( } n=302) \\
\text { (randomised: } \\
n=498)\end{array}$ & $\begin{array}{l}\text { Dronabinol vs. } \\
\text { Placebo, } \\
\text { percentage of } \\
\text { patients with } \\
\frac{\text { lesions } 34 \% \text { vs. }}{33 \% \text { after } 3 \text { years }} \\
(\mathrm{p}=0.87)\end{array}$ & 36 months \\
\hline & $\begin{array}{l}\text { New non- } \\
\text { enhancing T1 } \\
\text { lesions }\end{array}$ & $\begin{array}{l}\text { Lublin et al., } \\
\text { Lancet } 2016 \\
\text { (INFORMS study) }\end{array}$ & PPMS ( $n=970)$ & $\begin{array}{l}\text { Fingolimod } 0.5 \mathrm{mg} \\
\text { vs. Placebo, lesion } \\
\text { number per year } \\
0.09 \text { vs. } 0.24 \\
(p<0.001) ; \\
\text { number of } \\
\text { patients free of } \\
\text { lesions } 82 \% \text { vs. } \\
72 \%(p=0.003) \\
\text { after } 36 \text { months }\end{array}$ & 36 months \\
\hline & $\begin{array}{l}\text { Volume of T1 } \\
\text { lesions }\end{array}$ & $\begin{array}{l}\text { Hommes et al., } \\
\text { Lancet Neurol } \\
\text { 2004; Fazekas et } \\
\text { al., MSJ } 2005 \\
\text { (ESIMS study) }\end{array}$ & SPMS (n=318) & $\begin{array}{l}\text { Intravenous } \\
\text { Immunoglobulin } \\
\text { vs. Placebo, lesion } \\
\text { volume } 3.78 \mathrm{~mm}^{3} \\
\text { vs. } 3.68 \mathrm{~mm}^{3} \text { after } \\
1 \text { year (ns), } \\
3.58 \mathrm{~mm}^{3} \text { vs. } \\
3.59 \mathrm{~mm}^{3} \text { after } 2 \\
\text { years (ns) }\end{array}$ & 24 months \\
\hline & $\begin{array}{l}\text { T1/T2 lesion } \\
\text { volume ratio }\end{array}$ & $\begin{array}{l}\text { Hommes et al., } \\
\text { Lancet Neurol } \\
\text { 2004; Fazekas et } \\
\text { al., MSJ } 2005 \\
\text { (ESIMS study) }\end{array}$ & SPMS $(n=318)$ & $\begin{array}{l}\text { Intravenous } \\
\text { Immunoglobulin } \\
\text { vs. Placebo, ratio } \\
0.136 \text { vs. } 0.131 \\
\text { after } 1 \text { year (ns), } \\
0.123 \text { vs. } 0.136 \\
\text { after } 2 \text { years (ns) }\end{array}$ & 24 months \\
\hline $\begin{array}{l}\text { Combined } \\
\text { measures }\end{array}$ & $\begin{array}{l}\text { Combined unique } \\
\text { active lesions }\end{array}$ & $\begin{array}{l}\text { Secondary } \\
\text { Progressive } \\
\text { Efficacy Clinical } \\
\text { Trial of } \\
\text { Recombinant } \\
\text { Interferon-beta- } \\
1 \text { a in MS } \\
\text { (SPECTRIMS) } \\
\text { Study Group; Li et } \\
\text { al., Neurology } \\
2001 \text { (SPECTRIMS } \\
\text { study) }\end{array}$ & SPMS $(n=618)$ & $\begin{array}{l}\text { IFN beta-1a } 44 \mu \mathrm{g} \\
\text { vs. IFN beta-1a } \\
22 \mu \mathrm{g} \text { vs. placebo: } \\
\text { Median numbers } \\
\text { of combined } \\
\text { unique lesions: } \\
0.11,0.22 \text { and } \\
1.0, \text { respectively, } \\
\text { p = } 0.005 \text { (IFN } \\
\text { beta-1a } 22 \mu \mathrm{g} \text { vs. } \\
\text { placebo); } \\
\text { p<0.0001 (IFN } \\
\text { beta-1a } 44 \mu \mathrm{g} \text { vs. } \\
\text { placebo). }\end{array}$ & 36 months \\
\hline
\end{tabular}




\begin{tabular}{|c|c|c|c|c|c|}
\hline Brain atrophy & $\begin{array}{l}\text { Brain } \\
\text { parenchymal } \\
\text { fraction }\end{array}$ & $\begin{array}{l}\text { Hawker et al., Ann } \\
\text { Neurol } 2009 \\
\text { (OLYMPUS study) }\end{array}$ & PPMS (n=439) & $\begin{array}{l}\text { Rituximab vs. } \\
\text { Placebo, volume } \\
\text { change }-9.9 \mathrm{~cm}^{3} \\
\text { vs. }-10.8 \mathrm{~cm}^{3} \\
(p=0.62) \text { after } 96 \\
\text { weeks }\end{array}$ & 96 weeks \\
\hline & Percent change & $\begin{array}{l}\text { Hommes et al., } \\
\text { Lancet Neurol } \\
\text { 2004; Fazekas et } \\
\text { al., MSJ } 2005 \\
\text { (ESIMS study) }\end{array}$ & SPMS ( $n=318)$ & $\begin{array}{l}\text { Intravenous } \\
\text { Immunoglobulin } \\
\text { vs. Placebo, } \\
\text { percent change - } \\
0.30 \% \text { vs. }-0.13 \% \\
\text { after } 1 \text { year (ns), - } \\
0.11 \% \text { vs. }-0.06 \% \\
\text { after } 2 \text { years (ns) }\end{array}$ & 24 months \\
\hline & & $\begin{array}{l}\text { Freedman et al., } \\
\text { Neurology } 2011 \\
\text { (MAESTRO study) }\end{array}$ & SPMS (n=612) & $\begin{array}{l}\text { MBP8298 vs. } \\
\text { Placebo, percent } \\
\text { change among } \\
\text { DR2 }^{+} \text {or DR4 }{ }^{+}- \\
1.21 \% \text { vs. }-0.78 \% \\
\text { after } 24 \text { months } \\
\text { ( } p=0.440) \text {, among } \\
\text { DR2 } / D R 4^{-}-1.23 \% \\
\text { vs. }-0.62 \% \text { after } \\
24 \text { months } \\
(p=0.942)\end{array}$ & 24 months \\
\hline & & $\begin{array}{l}\text { Zajicek et al., } \\
\text { Lancet Neurol } \\
2013 \text { (CUPID } \\
\text { study) }\end{array}$ & $\begin{array}{l}\text { PPMS ( } n=191) \text {, } \\
\text { SPMS }(n=302) \\
\text { (randomised: } \\
n=498 \text { ) }\end{array}$ & $\begin{array}{l}\text { Dronabinol vs. } \\
\text { Placebo, yearly } \\
\text { percent change - } \\
0.68 \% \text { vs. }-0.66 \% \\
\text { after } 3 \text { years } \\
(p=0.94)\end{array}$ & 36 months \\
\hline & & $\begin{array}{l}\text { Lublin et al., } \\
\text { Lancet } 2016 \\
\text { (INFORMS study) }\end{array}$ & PPMS (n=970) & $\begin{array}{l}\text { Fingolimod } 0.5 \mathrm{mg} \\
\text { vs. Placebo, } \\
\text { percent change - } \\
1.49 \% \text { vs. }-1.53 \% \\
\text { ( } \mathrm{p}=0.673 \text { ) after } 36 \\
\text { months }\end{array}$ & 36 months \\
\hline & & $\begin{array}{l}\text { Montalban et al., } \\
\text { N Engl J Med. } \\
2016 \text { (ORATORIO } \\
\text { study) }\end{array}$ & PPMS (n=732) & $\begin{array}{l}\text { Ocrelizumab } \\
600 \mathrm{mg} \text { ( } 300 \mathrm{mg} \\
\text { x2) / } 24 \text { weeks IV } \\
\text { vs. placebo: } \underline{\text { rate }} \\
\text { of brain volume } \\
\underline{\text { loss: }-0.9 \% \text { vs. }-} \\
1.1 \%(p=0.0206)\end{array}$ & 120 weeks \\
\hline
\end{tabular}

Abbreviations: Gd: gadolinium; PPMS: primary progressive multiple sclerosis; SPMS: secondary progressive multiple sclerosis. 
Table 7: Phase II and 3 trials which used spinal cord MRI outcomes

\begin{tabular}{|c|c|c|c|c|}
\hline $\begin{array}{l}\text { Original } \\
\text { neuroimaging } \\
\text { outcome }\end{array}$ & Trials & $\begin{array}{l}\text { Condition (no. } \\
\text { of patients } \\
\text { randomised) }\end{array}$ & $\begin{array}{l}\text { Drug, effect } \\
\text { (vs. placebo/ another active arm) }\end{array}$ & $\begin{array}{l}\text { Duration of } \\
\text { the trial }\end{array}$ \\
\hline \multirow[t]{7}{*}{$\begin{array}{l}\text { Cervical cord } \\
\text { area }\end{array}$} & $\begin{array}{l}\text { Montalban et } \\
\text { al. Mult Scler } \\
\text { 2009, phase II }\end{array}$ & $\begin{array}{l}\text { PPMS }(n=49), \\
\text { transitional } \\
\text { progressive MS } \\
(n=24)\end{array}$ & $\begin{array}{l}\text { Interferon beta- } 1 b \text { ( } 250 \mu \text { g on } \\
\text { alternate days) vs. Placebo, percent } \\
\text { change in cord area }-1.6 \% \text { vs. }-1.3 \% \\
\text { after } 12 \text { months (ns), }-0.9 \% \text { vs. - } \\
1.6 \% \text { after } 24 \text { months (ns) }\end{array}$ & 24 months \\
\hline & $\begin{array}{l}\text { Leary et al. } \\
\text { Neurology } \\
\text { 2003, phase II }\end{array}$ & PPMS $(n=50)$ & $\begin{array}{l}\text { Interferon beta-1a ( } 30 \mu \mathrm{g} \text { vs. } 60 \mu \mathrm{g} \\
\text { per week) vs. Placebo, percent } \\
\text { change in cord area }-0.5 \% \text { vs. }-1.0 \% \\
\text { vs. } 0.3 \% \text { after } 12 \text { months (ns), - } \\
3.7 \% \text { vs. } 1.5 \% \text { vs. }-1.3 \% \text { after } 24 \\
\text { months (ns) }\end{array}$ & 24 months \\
\hline & $\begin{array}{l}\text { Lin et al. J } \\
\text { Neurol } \\
\text { Neurosurg } \\
\text { Psychiatry } \\
\text { 2003, phase II }\end{array}$ & $\begin{array}{l}\text { RRMS }(n=20) \\
\text { SPMS }(n=18)\end{array}$ & $\begin{array}{l}\text { Interferon beta- } 1 \mathrm{a}(44 \mu \mathrm{g} \text { three } \\
\text { times per week), percent change in } \\
\text { cord area }-1.0 \% \text { vs. }-1.7 \% \text { after } 6 \\
\text { months (ns), }-1.5 \% \text { vs. }-2.8 \% \text { after } \\
12 \text { months (ns), }-1.8 \% \text { vs. }-2.9 \% \\
\text { after } 18 \text { months (ns), }-4.5 \% \text { vs. - } \\
5.7 \% \text { after } 48 \text { months (ns) }\end{array}$ & 48 months \\
\hline & $\begin{array}{l}\text { Frank et al. } \\
\text { Mult Scler } \\
\text { 2002, phase II }\end{array}$ & $\begin{array}{l}\text { SPMS }(n=6) \\
\text { RRMS }(n=1)\end{array}$ & $\begin{array}{l}\text { RhIGF-1 (0.05 mg/kg twice a day), } \\
\text { not reported (ns) }\end{array}$ & 24 weeks \\
\hline & $\begin{array}{l}\text { Kapoor et al. } \\
\text { Lancet Neurol } \\
2010 \text {, phase II }\end{array}$ & SPMS $(n=120)$ & $\begin{array}{l}\text { Lamotrigine vs. Placebo, percent } \\
\text { change in cord area }-1.60 \% \text { vs. - } \\
1.26 \% \text { after } 24 \text { months (ns) }\end{array}$ & 24 months \\
\hline & $\begin{array}{l}\text { Kalkers et al. } \\
\text { Mult Scler } \\
\text { 2002, phase II }\end{array}$ & PPMS $(n=16)$ & $\begin{array}{l}\text { Placebo for } 12 \text { months vs. Riluzole } \\
\text { for following } 12 \text { months ( } 2 \times 50 \mathrm{mg} \\
\text { per day), percent change in cord } \\
\text { area }-2.0 \% \text { vs. }-0.2 \% \text { (not reported) }\end{array}$ & 24 months \\
\hline & $\begin{array}{l}\text { Yaldizli et al. } \\
\text { ECTRIMS 2015, } \\
\text { phase III } \\
\text { (INFORMS } \\
\text { study) }\end{array}$ & PPMS $(n=823)$ & $\begin{array}{l}\text { Fingolimod vs. Placebo, } \% \text { change } \\
\text { from baseline: percent change in } \\
\text { cord area }-2.04 \% \text { vs. }-2.44 \% \text { after } \\
24 \text { months (ns) }\end{array}$ & 24 months \\
\hline
\end{tabular}

Abbreviations: ns: not significant; PPMS: primary progressive multiple sclerosis; RRMS: relapsingremitting multiple sclerosis; SPMS: secondary progressive multiple sclerosis 
Table 8: Past and ongoing phase II and III trials which use OCT-related measures Optical Coherence Tomography

\begin{tabular}{|c|c|c|c|c|}
\hline $\begin{array}{l}\text { Original OCT } \\
\text { outcome }\end{array}$ & Trial & $\begin{array}{l}\text { Condition } \\
\text { (number of } \\
\text { patients } \\
\text { randomised) }\end{array}$ & Drug, effect & $\begin{array}{l}\text { Duration of the } \\
\text { trial }\end{array}$ \\
\hline \multirow[t]{3}{*}{$\begin{array}{l}\text { Retinal nerve } \\
\text { fibre layer } \\
\text { thickness }\end{array}$} & $\begin{array}{l}\text { Dorr et al. Trials } \\
\text { 2012, phase II }\end{array}$ & $\begin{array}{l}\text { RRMS and CIS } \\
(n=80)\end{array}$ & $\begin{array}{l}\text { Vitamin D (20400 IU every } \\
\text { other day) vs. Vitamin D (400 } \\
\text { IU every other day), ongoing }\end{array}$ & 24 months \\
\hline & $\begin{array}{l}\text { Horton et al. } \\
\text { Neurology 2013, } \\
\text { phase II }\end{array}$ & $\begin{array}{l}>6 \text { months after } \\
\text { ON in RRMS } \\
(n=22)\end{array}$ & $\begin{array}{l}\text { 4-aminopyridine vs. Placebo } \\
\text { (crossover), percent change - } \\
1.89 \% \text { vs. } 1.45 \% \text { after } 5 \text { weeks } \\
\text { for RNFL } 60-80 \mu \mathrm{m}(\mathrm{p}=0.01)\end{array}$ & 10 weeks \\
\hline & $\begin{array}{l}\text { Cambron et al. } \\
\text { Trials 2014, } \\
\text { phase II }\end{array}$ & $\begin{array}{l}\text { PPMS and } \\
\text { SPMS }(n=120 \\
\text { expected) }\end{array}$ & $\begin{array}{l}\text { Fluoxetine (40mg per day) vs. } \\
\text { Placebo, ongoing }\end{array}$ & 108 weeks \\
\hline & $\begin{array}{l}\text { Llufriu et al. PloS } \\
\text { ONE 2014, phase } \\
\text { II }\end{array}$ & RRMS (n=9) & $\begin{array}{l}\text { Autologous Mesenchymal } \\
\text { Stem Cells vs. Placebo, } \\
\text { change in thickness OD - } \\
0.2 \mu \mathrm{m} \text { vs. } 0.0 \mu \mathrm{m}(\mathrm{ns}) \text { and OS - } \\
0.33 \mu \mathrm{m} \text { vs. }-0.22 \mu \mathrm{m} \text { (ns) after } \\
6 \text {, and OD }-0.02 \mu \mathrm{m} \text { vs. - } \\
0.02 \mu \mathrm{m} \text { (ns) and OS }-0.4 \mu \mathrm{m} \\
\text { vs. } 0.0 \mu \mathrm{m} \text { (ns) after } 12 \\
\text { months }\end{array}$ & 12 months \\
\hline & $\begin{array}{l}\text { Diem et al. BMJ } \\
\text { Open 2015, } \\
\text { phase II }\end{array}$ & $\begin{array}{l}\text { Acute ON in CIS } \\
(n=100, \\
\text { expected })\end{array}$ & $\begin{array}{l}\text { Erythropoietin ( } 33000 \text { IU per } \\
\text { day for } 3 \text { consecutive days) } \\
\text { vs. Placebo, ongoing }\end{array}$ & 6 months \\
\hline & $\begin{array}{l}\text { Mckee et al. BMJ } \\
\text { Open 2015, } \\
\text { phase II }\end{array}$ & $\begin{array}{l}\text { Acute ON in CIS } \\
\text { or in RRMS } \\
\text { ( } n=46, \\
\text { expected) }\end{array}$ & $\begin{array}{l}\text { Amiloride vs. Placebo, } \\
\text { ongoing }\end{array}$ & 12 months \\
\hline & $\begin{array}{l}\text { Rice et al. Trials } \\
\text { 2015, phase II }\end{array}$ & $\begin{array}{l}\text { PPMS }(n=20) \\
\text { SPMS }(n=20) \\
\text { (expected) }\end{array}$ & $\begin{array}{l}\text { Autologous bone marrow } \\
\text { infusion, ongoing }\end{array}$ & 12 months \\
\hline & $\begin{array}{l}\text { Salari et al. J Res } \\
\text { Med Sci 2015, } \\
\text { phase II }\end{array}$ & $\begin{array}{l}\text { Acute ON in CIS } \\
(n=52)\end{array}$ & $\begin{array}{l}\text { Vitamin D (50000 IU per } \\
\text { week) vs. Placebo, change in } \\
\text { thickness }-19.9 \mu \mathrm{m} \text { vs. - } \\
17.6 \mu \mathrm{m}(\mathrm{ns})\end{array}$ & 6 months \\
\hline & $\begin{array}{l}\text { Sergott et al. J } \\
\text { Neurol Sci 2015, } \\
\text { phase II }\end{array}$ & $\begin{array}{l}\text { Acute ON in CIS } \\
(n=34)\end{array}$ & $\begin{array}{l}\text { Atacicept vs. Placebo, change } \\
\text { in thickness }-8.6 \mu \mathrm{m} \text { vs. - } \\
17.3 \mu \mathrm{m}(\mathrm{p}=0.07)\end{array}$ & 36 weeks \\
\hline & $\begin{array}{l}\text { Raftopoulos et } \\
\text { al. Lancet Neurol } \\
\text { 2016, phase II }\end{array}$ & $\begin{array}{l}\text { Acute ON in CIS } \\
\text { and RRMS } \\
(n=86)\end{array}$ & $\begin{array}{l}\text { Phenytoin vs. Placebo, } 30 \% \\
\text { reduction in thickness in the } \\
\text { extent of layer loss with } \\
\text { Phenytoin }(p=0.021)\end{array}$ & 6 months \\
\hline
\end{tabular}




\begin{tabular}{|c|c|c|c|c|}
\hline $\begin{array}{l}\text { Ganglion cell } \\
\text { layer thickness }\end{array}$ & $\begin{array}{l}\text { Mckee et al. BMJ } \\
\text { Open 2015, } \\
\text { phase II }\end{array}$ & $\begin{array}{l}\text { ON in CIS or in } \\
\text { RRMS }(n=46)\end{array}$ & $\begin{array}{l}\text { Amiloride vs. Placebo, } \\
\text { ongoing }\end{array}$ & 12 months \\
\hline \multirow[t]{8}{*}{$\begin{array}{l}\text { Macular } \\
\text { volume }\end{array}$} & $\begin{array}{l}\text { Dorr et al. Trials } \\
\text { 2012, phase II }\end{array}$ & $\begin{array}{l}\text { RRMS and CIS } \\
(n=80)\end{array}$ & $\begin{array}{l}\text { Vitamin D (20400 IU every } \\
\text { other day) vs. Vitamin D (400 } \\
\text { IU every other day), ongoing }\end{array}$ & 24 months \\
\hline & $\begin{array}{l}\text { Zarbin et al } \\
\text { Ophthalmlogy } \\
\text { 2013, phase II } \\
\text { and phase III } \\
\text { (pooled data } \\
\text { analysis) }\end{array}$ & RRMS $(n=2615)$ & $\begin{array}{l}\text { Fingolimod, macular oedema } \\
\text { detection }\end{array}$ & 5 years \\
\hline & $\begin{array}{l}\text { Cambron et al. } \\
\text { Trials 2014, } \\
\text { phase II }\end{array}$ & $\begin{array}{l}\text { PPMS and } \\
\text { SPMS ( } n=120 \text {, } \\
\text { expected) }\end{array}$ & $\begin{array}{l}\text { Fluoxetine (40mg per day) vs. } \\
\text { Placebo, ongoing }\end{array}$ & 108 weeks \\
\hline & $\begin{array}{l}\text { Llufriu et al. Plos } \\
\text { ONE 2014, phase } \\
\text { II }\end{array}$ & RRMS (n=9) & $\begin{array}{l}\text { Autologous Mesenchymal } \\
\text { Stem Cells vs. Placebo, } \\
\text { volume change OD }-0.02 \mathrm{~mm}^{3} \\
\text { vs. } 0.0 \mathrm{~mm}^{3}(\mathrm{~ns}) \text { and OS - } \\
0.02 \mathrm{~mm}^{3} \text { vs. }-0.02 \mathrm{~mm}^{3} \text { (ns) } \\
\text { after } 6 \text {, and OD }-0.02 \mathrm{~mm}^{3} \text { vs. } \\
0.0 \mathrm{~mm}^{3} \text { (ns) and OS }-0.01 \mathrm{~mm}^{3} \\
\text { vs. } 0.01 \mathrm{~mm}^{3} \text { (ns) after } 12 \\
\text { months }\end{array}$ & 12 months \\
\hline & $\begin{array}{l}\text { Diem et al. BMJ } \\
\text { Open 2015, } \\
\text { phase II }\end{array}$ & $\begin{array}{l}\text { Acute ON in CIS } \\
(n=100, \\
\text { expected) }\end{array}$ & $\begin{array}{l}\text { Erythropoietin ( } 33000 \text { IU per } \\
\text { day for } 3 \text { consecutive days) } \\
\text { vs. Placebo, ongoing }\end{array}$ & 6 months \\
\hline & $\begin{array}{l}\text { Mckee et al. BMJ } \\
\text { Open 2015, } \\
\text { phase II }\end{array}$ & $\begin{array}{l}\text { ON in CIS or in } \\
\text { RRMS ( } n=46 \\
\text { expected) }\end{array}$ & $\begin{array}{l}\text { Amiloride vs. Placebo, } \\
\text { ongoing }\end{array}$ & 12 months \\
\hline & $\begin{array}{l}\text { Rice et al. Trials } \\
\text { 2015, phase II }\end{array}$ & $\begin{array}{l}\text { PPMS }(n=20) \\
\text { SPMS }(n=20) \\
\text { (expected) }\end{array}$ & $\begin{array}{l}\text { Autologous bone marrow } \\
\text { infusion, ongoing }\end{array}$ & 12 months \\
\hline & $\begin{array}{l}\text { Raftopoulos et } \\
\text { al. Lancet Neurol } \\
\text { 2016, phase II }\end{array}$ & $\begin{array}{l}\text { Acute ON in CIS } \\
\text { and RRMS } \\
(n=86)\end{array}$ & $\begin{array}{l}\text { Phenytoin vs. Placebo, } 34 \% \\
\text { volume reduction in the } \\
\text { extent of volume loss with } \\
\text { Phenytoin ( } p=0.005)\end{array}$ & 6 months \\
\hline \multirow[t]{2}{*}{$\begin{array}{l}\text { Macular } \\
\text { thickness }\end{array}$} & $\begin{array}{l}\text { Mckee et al. BMJ } \\
\text { Open 2015, } \\
\text { phase II }\end{array}$ & $\begin{array}{l}\text { ON in CIS or in } \\
\text { RRMS ( } n=46, \\
\text { expected) }\end{array}$ & $\begin{array}{l}\text { Amiloride vs. Placebo, } \\
\text { ongoing }\end{array}$ & 12 months \\
\hline & $\begin{array}{l}\text { Salari et al. J Res } \\
\text { Med Sci 2015, } \\
\text { phase II }\end{array}$ & $\begin{array}{l}\text { Acute ON in CIS } \\
(n=52)\end{array}$ & $\begin{array}{l}\text { Vitamin D (50000 IU per } \\
\text { week) vs. Placebo, thickness } \\
\text { change }-0.8 \mu \mathrm{m} \text { vs. }-3.1 \mu \mathrm{m} \text { (ns) }\end{array}$ & 6 months \\
\hline
\end{tabular}

Abbreviations: CIS: clinically isolated syndrome; ns: not significant; ON: optic neuritis; PPMS: primary progressive multiple sclerosis; RRMS: relapsing-remitting multiple sclerosis; SPMS: secondary progressive multiple sclerosis. 


\section{Phase 3 clinical trials per year}

10

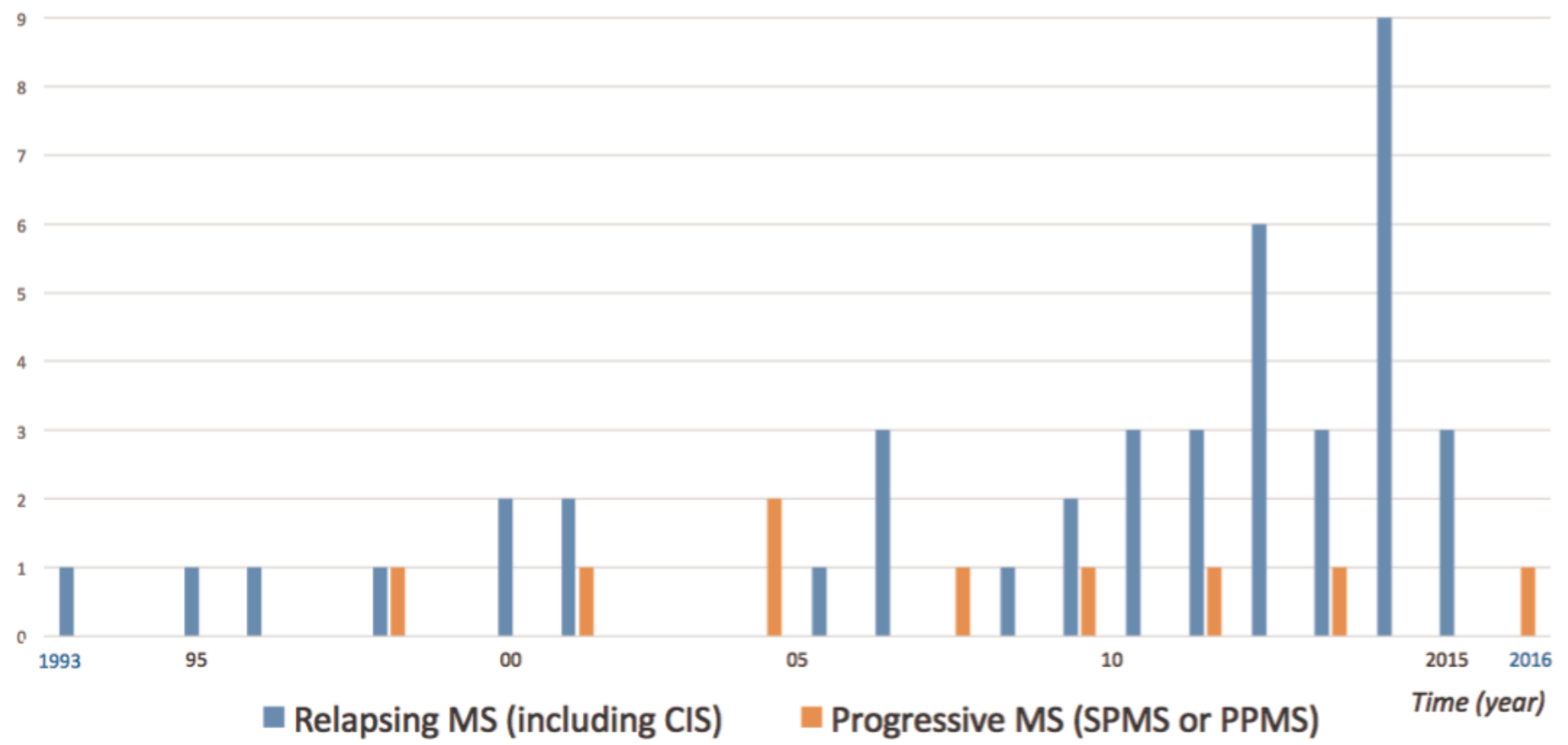




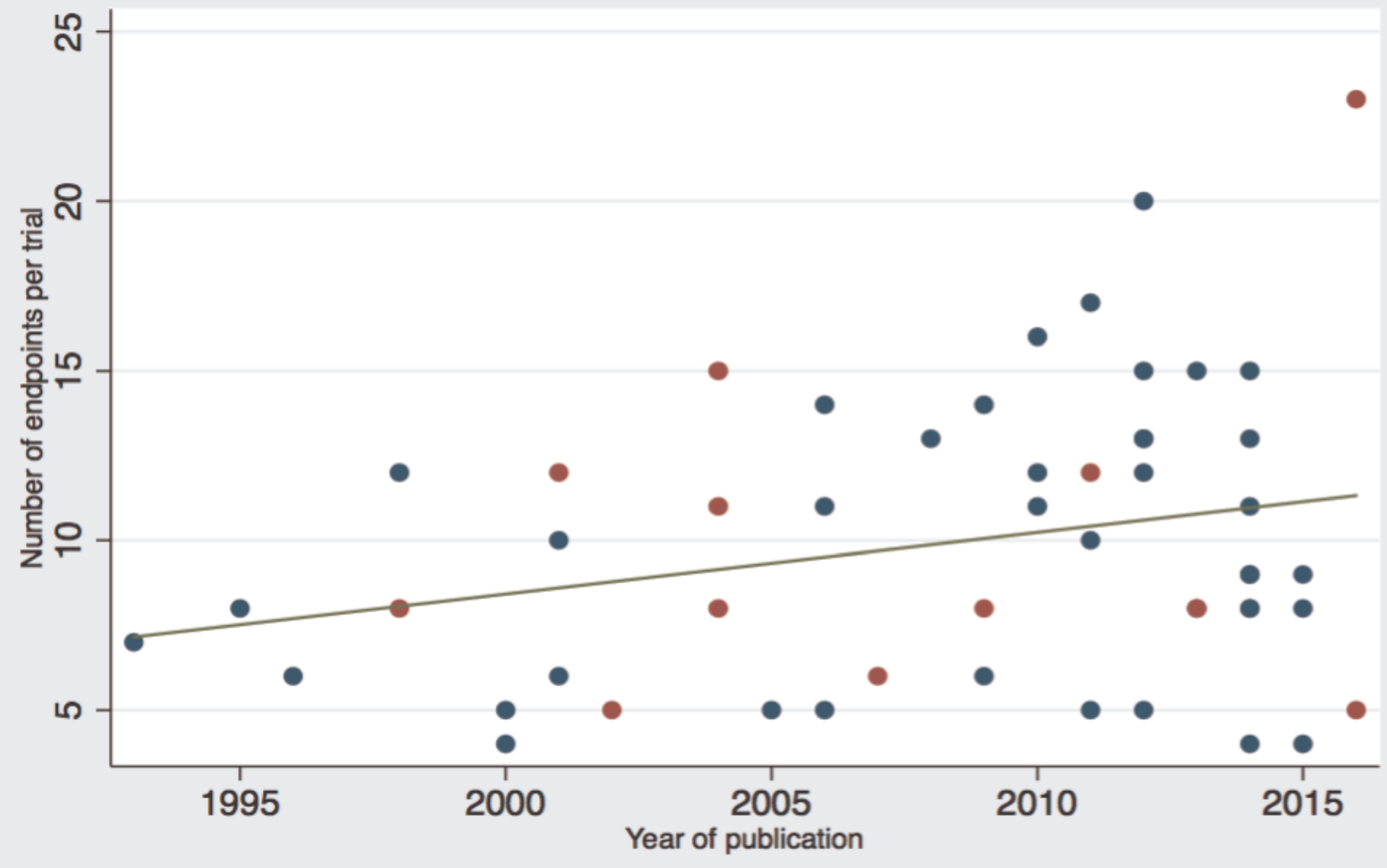

- Relapsing MS - Progressive MS 


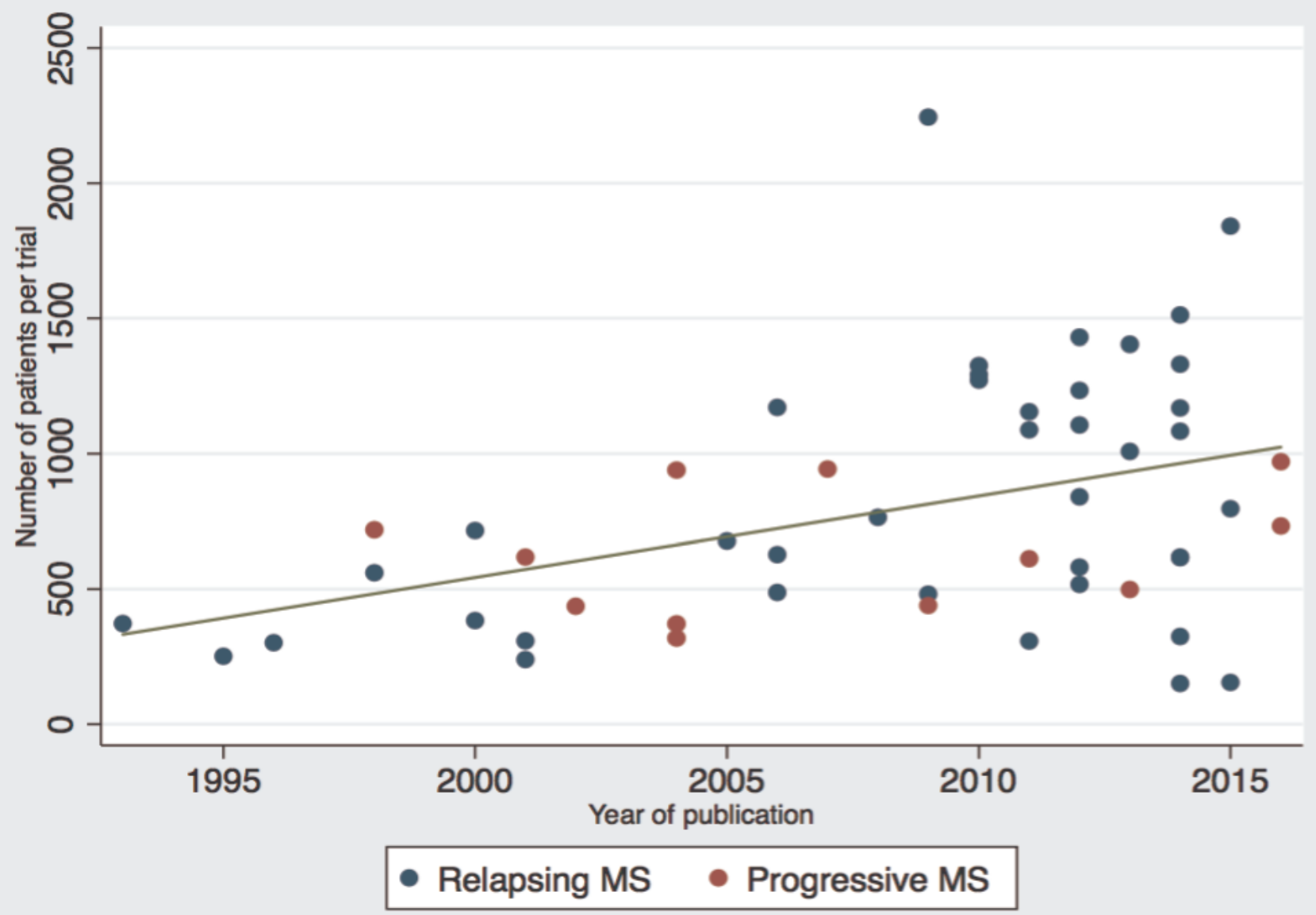




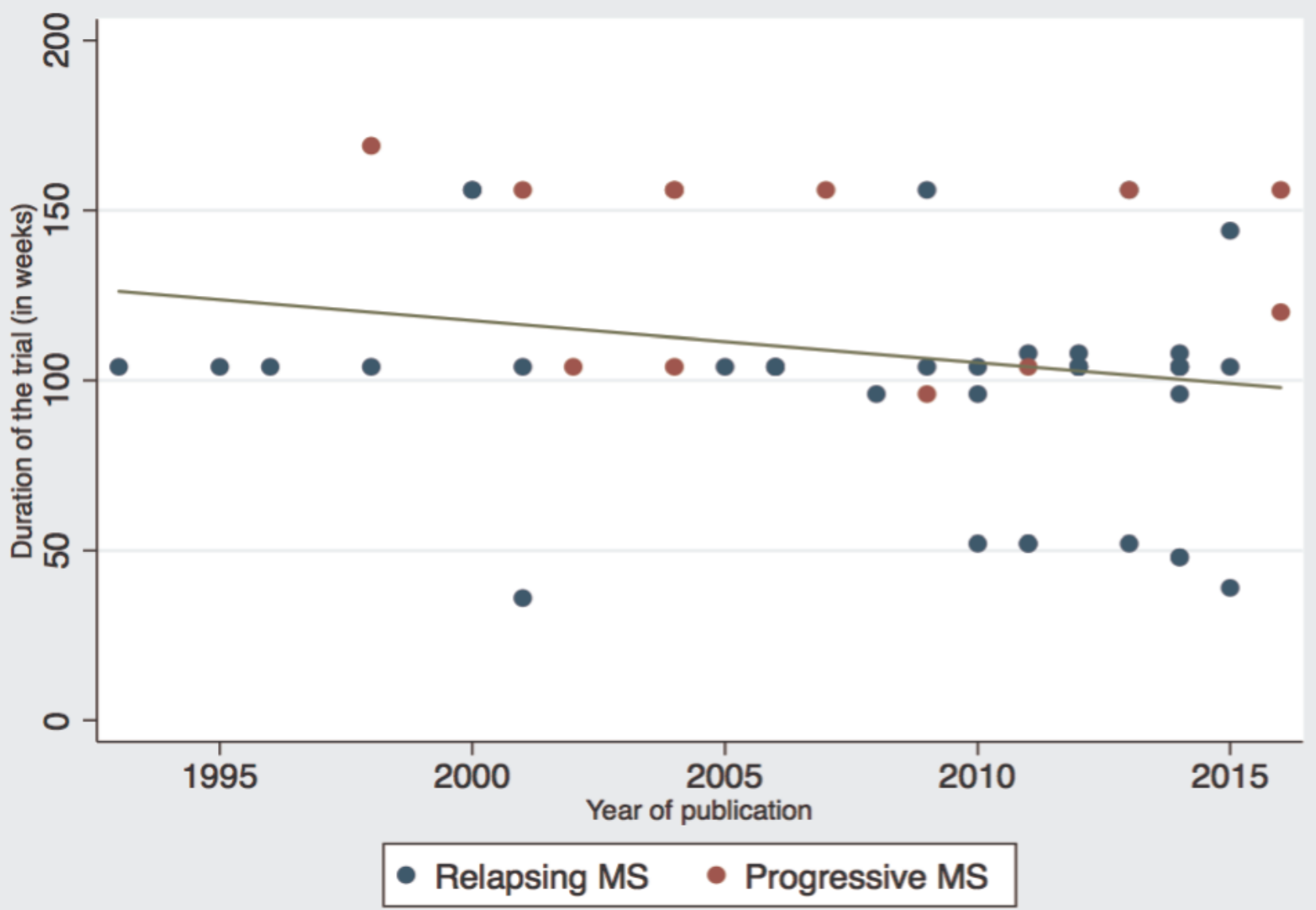

